\title{
State Fragility and International Security: The Rise of Salafi-Jihadi Groups in a World of Fragile States
}

\author{
By \\ Said Yaqub Ibrahimi
}

\begin{abstract}
A thesis submitted to the Faculty of Graduate and Postdoctoral Affairs in partial fulfillment of the requirements for the degree of

Doctor of Philosophy

In

Political Science
\end{abstract}

Carleton University

Ottawa, Ontario 


\begin{abstract}
Since the end of the Cold War, extremist Islamism has become a focal point of international security debate in academic and policy research. Much of the existing literature on Salafi-Jihadi Groups (SJGs), conventionally known as terrorist groups, examines the root causes of the emergence of these groups through the lens of three levels: individual, group, and international levels. Thus, individual extremists' desire for jihad, Islamism as a group ideology, and the sole great power's post-Cold War policies in the Middle East are considered as the three dominant root causes of the emergence of SJGs in the literature. If these three causal determinants are to hold, it begs the question of why SJGs do not emerge in every Muslim majority country where these elements persist. Why, for instance, did individual jihadis' personal desire for transnational jihad, Islamist ideology, and the US post-Cold War policies produce SJGs in Afghanistan and the post-Saddam Hussein Iraq but not in Saudi Arabia and Qatar? What factor, then, is responsible for this contradictory outcome in countries which in terms of the presence of the root cause of SJGs are similar? Taking these questions into account, I consider the degree of state fragility countries to be responsible for this contradictory outcome. This dissertation examines state fragility as a condition, but not a direct cause, of the rise of SJGs. It engages with a three-decade-long debate on the relationship between state fragility and terrorism and examines the empirical findings through the lens of international relations, international security, and development theories.
\end{abstract}

Keywords: Sovereign State; State Fragility; Salafi-Jihadi Groups; Terrorism; Islamism; Afghanistan; Iraq 


\section{Dedication:}

I dedicate this dissertation to the beauty of my motherland, Afghanistan, which I love eternally which has suffered from both state fragility and extremism in the hopes she rises more glorious than one can imagine. 


\section{Acknowledgement}

I had a great opportunity to write this dissertation under the supervision of Professor Elinor Sloan, a distinguished scholar, a great teacher, a professional mentor and a caring colleague. I also had the opportunity to work with Professor Brian Schmidt who familiarized me with the mystery of IR theory and Professor David Carment who guided me how to connect theory to data as my thesis committee members. I thank my committee for their support over the past five years. I would not have been able to write this dissertation without their guidance and support.

I significantly benefited from the intellectual and friendly environment of the Department of Political Science at Carleton University. Many professors and graduate students in the Department contributed to the success of this project in different ways. I thank them all. This project was financially supported by my Department's generous scholarship and the Social Sciences and Humanities Research Council of Canada's doctoral fellowship which I greatly appreciate. I have been lucky to live in an intellectual environment of family and friends giving me the opportunity to discuss my early findings without concerns of formality. I deeply appreciate and will always remember their intellectual and inspirational support.

I went to school in Afghanistan when the country was broken by war and completed my Bachelor in Law and Political Science when the country was recovering. Regardless of what situation the country was in, I was treated and taught with love and passion by teachers who regularly worked part time in construction and other hard labor jobs to support their families and worked in school for free for years, because they "had a dream." My grit and believe in hardworking is deeply inspired by those spirited and brave teachers. I deeply respect and thank them and wish their dreams come true soon. Finally, I thank my wife, Noorin, for her believe on me and her sincere support. 


\section{Contents}

\section{Chapter I}

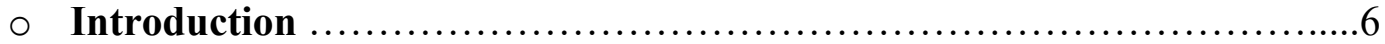

○ Conceptualizing Key Terms: The State, State Fragility and SJGs............14

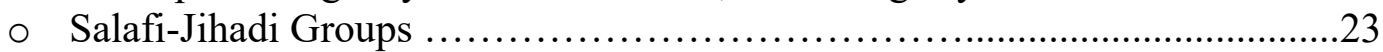

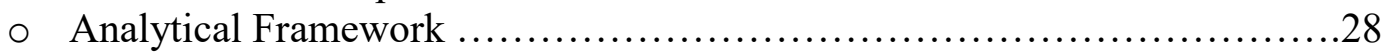

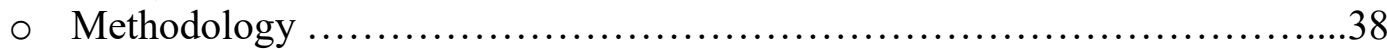

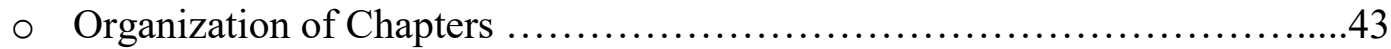

\section{Chapter II}

○ State and State Fragility in Muslim Societies; Salafi-Jihadi Groups......46

$\circ$ The Sovereign State and Its Extension in Muslim Societies ...................46

- State Fragility in Muslim Countries...................................55

○ Salafi-Jihadi Group: Background .....................................58

○ Development of SJGs................................................ 67

○ Typology: PIGs vs. SJGs ............................................. 71

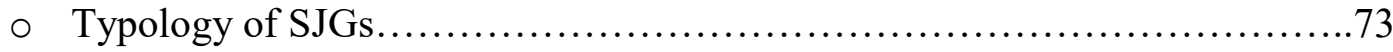

\section{Chapter III}

○ Root Causes of al-Qaeda............................................... 78

○ Individual Level: Personal Motivations................................... 90

○ Group Level: Salafi-Jihadism.........................................99

○ International Level: System Shift and Its Consequences.................... 102

\section{Chapter IV}

- State Fragility in Afghanistan and the Rise of al-Qaeda................. 114

- From State Formation to State Fragility...............................116

- State-Building Policies: State Conservatism and Social Transformation........119

○ Civil War and State Fragility........................................... 126

- State Fragility and the Emergence of al-Qaeda.............................128

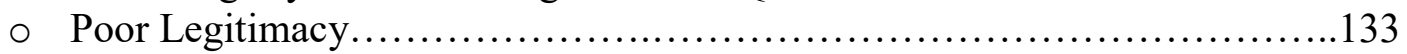

○ Poor Authority..................................................... 142

○ Lack of Capacity..................................................... 149 


\section{Chapter V}

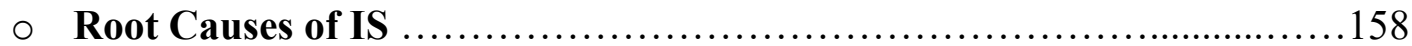

○ Post-Saddam Insurgency ............................................... 162

- Zarqawi and the Doctrine of the Caliphate................................. 163

○ From AQI to IS: the Formation of the Caliphate............................ 168

○ Individual Level...................................................... 175

○ Group Level: Salafi-Jihadism.......................................... 181

○ International Level..................................................... 189

\section{Chapter VI}

$\circ$ State Fragility in post-Saddam Iraq and the Rise of IS $\ldots \ldots \ldots \ldots \ldots \ldots \ldots \ldots$

○ State Formation and State Fragility....................................... 198

- The Monarchical Period (1921-1958)........................................ 199

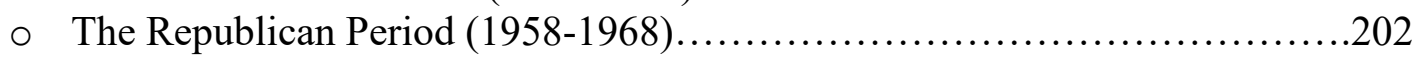

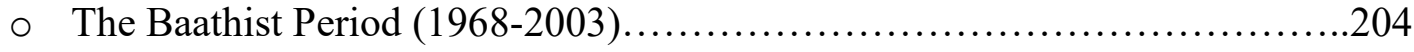

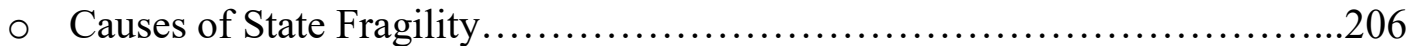

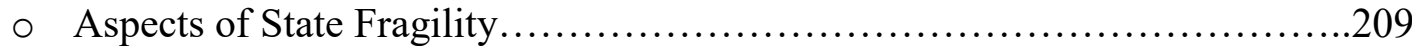

- 1. Lack of Legitimacy:

○ 1.1. Lack of Political Participation........................................2 213

○ 1.2. Sectarian Politics................................................. 222

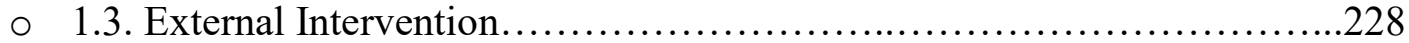

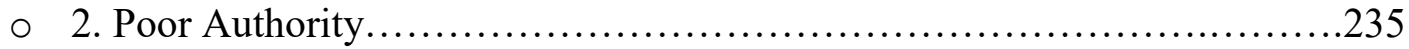

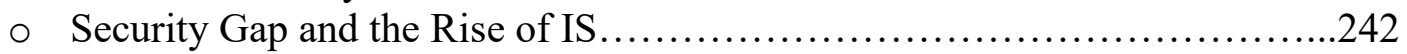

○ 3 . Lack of Capacity................................................ 250

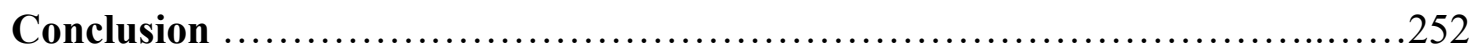

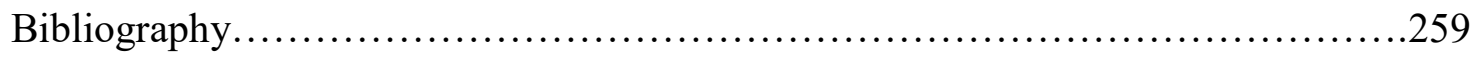


Since the end of the Cold War, extremist Islamism has become a focal point of international security debates in academic and policy research. Much of the security studies literature concerning the nature of Salafi-Jihadi Groups (SJGs), also known as terrorist groups, discusses the root causes of their emergence and aspects of their threat to international security in a specific context or different level of analysis. ${ }^{1}$ Putting this literature together, scholars have examined the causes of the phenomenon at three levels of analysis, namely, the individual, the group and the international/environmental levels. ${ }^{2}$ Thus, individual extremists' desire for jihad, $^{3}$ Islamism/Salafism as a group ideology, ${ }^{4}$ and the United States' post-Cold War foreign and military policies in the Middle East ${ }^{5}$ are considered as the three dominant causes of the emergence of SJGs

\footnotetext{
${ }^{1}$ Ami Pedahzur, ed. Root Causes of Suicide Terrorism: The Globalization of Martyrdom. (London and New York: Routledge 2006; Louise Richardson, ed., The Roots of Terrorism (New York and London: Routledge, 2006); Youssef M. Choueiri, Islamic Fundamentalism: The Story of Islamist Movements, $3^{\text {rd }}$ Edition, (London: Continuum, 2010).

${ }^{2}$ Assaf Moghadam, "The Roots of Suicide Terrorism: A Multi-Causal Approach," in Root Causes of Suicide Terrorism: The Globalization of Martyrdom, ed. Ami Pedahzur (London and New York: Routledge 2006), 81-107; S. Yaqub Ibrahimi, "Theory of the Rise of al-Qaeda," Behavioral Sciences of Terrorism and Political Aggression, 10(2), 2018: 138-157;

${ }^{3}$ Jerrold M. Post, The Mind of the Terrorist: The Psychology of Terrorism from the IRA to Al-Qaeda (New York: Palgrave MacMillan, 2007); Jerrold M. Post, "The Psychological Dynamics of Terrorism," in The Roots of Terrorism, ed. Louise Richardosn (New York and London: Routledge, 2006); Jerold, M Post, "When Hatred is Bred in the Bone: the Sociocultural Underpinnings of Terrorist Psychology," in The Making of a Terrorist: Recruiting, Training and Root Causes, edited by James J. F. Forest, vol. 2 (Westport, Connecticut, London: Praeger Security International, 2006); A. W. Kruglanski and S. Fishman, "The Psychology of Terrorism: 'Syndrome' Versus 'Tool' Perspectives," Terrorism and Political Violence 18/2 (2006):193-215; John Horgan, "Understanding Terrorist Motivation: A SocioPsychological Perspective," in Mapping Terrorism Research: State of the Art, gaps and future direction, ed. Magnus Ranstorp (London and New York: Routledge, 2007).

${ }^{4}$ Bassam Tibi, Islamism and Islam (New Haven and London: Yale University Press, 2012); Olivier Roy, "Terrorism as Deculturation." In The Roots of Terrorism. Edited by Louise Richardson, 159-171 (New York and London: Routledge, 2006); Mark Sedgwick, "Al-Qaeda and the Nature of Religious Terrorism," Terrorism and Political Violence 16/4 (2004): 795-814; Fawaz A. Gerges, The Far Enemy: Why Jihad Went Global, (New York: Cambridge University Press, 2005); John L. Esposito, "Terrorism and the Rise of Political Islam," in The Roots of Terrorism, ed. Louise Richardson (New York and London: Routledge, 2006), 143-158.

${ }^{5}$ Simon W. Murden, Islam, the Middle East and the New Global Hegemony (Boulder London: Lynne Rienner Publishers, 2002); Stephen Zunes, "The United States: A Hegemon Challenged," in The International Relations of the Contemporary Middle East: Subordination and After, ed. Tareq Y. Ismael and Glenn E. Terry (London and New York: Rutledge, 2014); Jane Corbin, Al-Qaeda: In Search of the Terror Network that Threatens the World (New
} 
in the literature. If these three causal determinants are to hold, it begs the question of why SJGs do not emerge in every Muslim country where these elements persist. Why, for instance, did individual jihadis' personal desire for transnational jihad, Islamist ideology, and the US post-Cold War policies produce JSGs in Afghanistan and post-Saddam Hussein Iraq but not in Saudi Arabia and Iraq under Saddam? What factor, then, is responsible for this contradictory outcome in countries which in terms of the presence of the root cause of SJGs are similar?

Taking these questions into account, I consider the degree of state fragility in Muslim countries to be responsible for this contradictory outcome. Empirical evidence shows that individual jihadis, primarily motivated by Islamist ideology and discontent with the post-Cold War US foreign and military policies in the Middle East, have been only able to establish SJGs in highly fragile Muslim majority states. Ten out of the top twenty most fragile states of the world are Muslim majority states which include Somalia, Sudan, Chad, Afghanistan, Yemen, Pakistan, Iraq, Syria, Niger, and Nigeria. ${ }^{6}$ All of these states have experienced the emergence and expansion of SJGs, including al-Shabaab in Somalia, the Taliban and al-Qaeda in Afghanistan, al-Qaeda in Arabian Peninsula (AQAP) in Yemen, IS in Iraq and Syria, and Boko Haram in Nigeria, Niger, and Chad. This general observation explains a meaningful relationship between state fragility and the emergence of SJGs in the Muslim world. By contrast, in countries such Saudi Arabia in which the three-level root causes persisted, strong statehood did not allow for the emergence of individual extremists as operative groups. Therefore, thousands of individual Saudi jihadis were forced to leave their country of origin to form or join a jihadi group in highly fragile Muslim states such as

York: Thunder's Mouth Press, 2002); Fawaz Gerges, The rise and fall of al-Qaeda (New York, NY: Oxford University Press, 2011); Robert A. Pape, Dying to Win: The Strategic Logic of Suicide Terrorism (London: Random House, 2006).

${ }^{6}$ Nate Haken et al. Fragile States Index 2014. Washington D. C. The Fund For Peace Publication, 2014), 2-5. http://ffp.statesindex.org/indicators 
Afghanistan and Iraq. ${ }^{7}$ According to the Fragile States Index provided by the Fund for Peace, Saudi Arabia is ranked $96^{\text {th }}$, more stable than Israel $\left(67^{\text {th }}\right)$ and China $\left(68^{\text {th }}\right) .^{8}$

While this general observation explains a meaningful relationship between state fragility and the emergence of SJGs, the literature on the relationship between the two phenomena lacks detailed explanations about how does state fragility contribute to the formation of SJGs. A number of scholars have developed general theories concerning the relationship between the two phenomena but they have not addressed the question of how through case-oriented qualitative research. ${ }^{9}$ The existing literature on the relationship between state fragility and the emergence of SJGs, in general, can be categorized into four groups. First, a large segment of the literature, particularly Large-N studies, is concerned with the role of state fragility in providing safe havens and operational facilities for SJGs. ${ }^{10}$ This literature emphasizes that fragile states are more prone to harboring terrorist organizations than stronger states. However, this literature does not specifically discuss how and what aspects of state fragility contribute to the emergence of SJGs in

\footnotetext{
${ }^{7}$ On Saudi jihadis in Iraq, for instance, see Nawaf Obaid and Anthony Cordesman, Saudi Militants in Iraq: Assessment and Kingdom's Response (Washington D.C.: Center for Strategic and International Studies, September 19, 2005), 4-7; Thomas Hegghammer, 'Saudis in Iraq: Patterns of Radicalization and Recruitment,' Cultures and Conflicts 2008, 11; Faiza Saleh Ambah, "Saudi Fighters Cross Border to Kill Infidels," Washington Times, August 31, 2003 http://www.washingtontimes.com/news/2003/aug/31/20030831-121933-2108r/; Shaista Aziz, "Saudi Fighters 'Join Resistance' in Iraq," Al-Jazeera, October 28, 2003 http://www.aljazeera.com/archive/2003/10/2008410141418821563.html

${ }^{8}$ Haken et al. Fragile States Index 2014, 4-5.

${ }^{9}$ For example, J. A. Piazza, "Draining the Swamp: Democracy Promotion, State Failure, and Terrorism in 19 Middle Eastern Countries," Studies in Conflict and Terrorism 30/6 (2007): 521-539; J. A. Piazza, "Do Failed and Failing States Promote Transnational Terrorism?” International Studies Quarterly 52/3 (Sep., 2008): 469-488; Karin von Hippel, "The Roots of Terrorism: Probing the Myths," The Political Quarterly 73 (2002): 25-39; Peter Tikuisis, "On the Relationship between the Week States and Terrorism," Behavioral Science of Terrorism and Political Aggression 1/1 (2009): 66-79; C.C.B. Kittner, "The Role of Safe Havens in Islamist Terrorism," Terrorism and Political Violence, 19 (2007): 307-329; Ted Robert Gurr, "Economic Factors," in The Roots of Terrorism, ed. Louise Richardson (New York: Routledge, 2006), 85-102; J. J. Hewitt, J. Wilkenfeld.

${ }^{9}$ Tikuisis, "On the Relationship," 65; Piazza, "Do Failed and Failing States Promote," 483.

${ }^{10}$ Stewart Patrick, Weak Links: Fragile States, Global Threats and International Security (New York: Oxford University Press, 2011), 79; Susan E. Rice and Stewart Patrick, Index of State Weakness in the Developing World (Washington D.C: The Brookings Institution Press, 2008), 3.
} 
the first place. Second, some scholarly work considers a weak link between the two phenomena. ${ }^{11}$ Patrick (2011), for example, sees an imperfect relationship between state fragility and the emergence of SJGs, ${ }^{12}$ and Coggins (2015) argues that the relationship is complicated, as there is no link in most of the cases. ${ }^{13}$ The third group of the literature indicates a strong relationship between state fragility and SJGs considering state fragility as a direct cause of terrorism. ${ }^{14}$ Tikuisis (2009) and Piazza (2008), for example, consider a "strong quantifiable" relationship between the two phenomena. ${ }^{15}$ And finally, a number of scholarly works reject any causal link or correlation between state fragility and the emergence of terrorist groups. ${ }^{16}$ According to Newman (2007), for example, terrorist organizations operate in weak and failed states but it is not necessarily weak or failed statehood which explains the emergence of those groups. ${ }^{17}$

This literature shares one common ground which is a concentration on the causal role of state fragility on the formation of SJGs. By focussing exclusively on whether state fragility is a cause of terrorism or not, scholars have failed to examine the broader impact of state fragility on the formation of terrorist groups. As a result, the role of state fragility as a condition of the emergence of SJGs is entirely ignored in the academic debate. This dissertation, adding state

\footnotetext{
${ }^{11}$ Stewart Patrick, Weak Links; James M. Lutz and Brenda J. Lutz, Terrorism: Origins and Evolution (New York: Palgrave, 2005); W. Eubank, and L. "Weinberg. Terrorism and Democracy: Perpetrators and Victims," Terrorism and Political Violence 13/1 (2001): 155-164; Tim Krieger and Daniel Meierrieks, "What Causes Terrorism," Public Choice 147 (2011): 7; Bridget L. Coggins, "Does State Failure Cause Terrorism? An Empirical Analysis (19992008)," Journal of Conflict Resolution 59/3 (2015): 455-483.

${ }_{12}^{12}$ Patrick, Weak Links, 61-105.

${ }^{13}$ Coggins, State Failure Cause Terrorism, 457.

${ }^{14}$ Piazza, "Draining the Swamp;" Piazza, "Do Failed and Failing States Promote Transnational Terrorism?;" Hippel, "The Roots of Terrorism;" Tikuisis, "On the Relationship Between the Week States and Terrorism;" Kittner, "The Role of Safe Havens in Islamist Terrorism;" Gurr, "Economic Factors."

${ }^{15}$ Tikuisis, "On the Relationship," 65; Piazza, "Do Failed and Failing States Promote," 483.

${ }^{16}$ Edward Newman, "Weak States, State Failure, and Terrorism," Terrorism and Political Violence 19 (2007): $463-$ 488; David Chandler. Empire in Denial: The Politics of State-Building (London: Pluto Press, 2006); Aidan Hehir. "The Myth of the Failed State and the War on Terror: A Challenge to the Conventional" Wisdom: Journal of Intervention and Statebuilding 1/3 (Sep. 2007): 307-332.

${ }^{17}$ Newman, "Weak States," 465.
} 
fragility as a condition variable $e^{18}$ to the causal model of the rise of SJGs, fills this gap. This dissertation engages in a three-decade-long debate on the relationship between state fragility and terrorism and examines the empirical findings through the lens of International Relations (IR), international security, and development theories.

This dissertation asks: how do specific aspects of state fragility in Muslim countries contribute to the emergence of SJGs? I work with the hypothesis that if the three-level root causes of the emergence of SJGs (motivated jihadis at individual level, Salafi-Jihadi ideology at group level, and popular anger against the US post-Cold War foreign and military policies in the Middle East at international level) are in place, then specific aspects of state fragility in a Muslim country(s) provide the conditions necessary for the emergence of a $S J G(s)$.

Thus, unlike previous scholarly work that focuses on the causal relationship between the two phenomena, I do not consider state fragility as a direct cause of the emergence of SJGs. Rather, I argue that the relationship between the three-level causes, as articulated, and the emergence of SJGs is conditioned by state fragility in Muslim majority countries. Thus, I add state fragility as a "condition variable" ${ }^{19}[$ not an independent variable] to the existing debate on state fragilityterrorism nexus.

Condition variables "magnify, but not multiply," the impact of independent variables on the dependent variable. ${ }^{20}$ The impact of an independent variable(s) on the dependent variable, according to van Evera (1997), can be magnified "by a high value on the condition variable and reduced by a low value for it." ${ }^{21}$ In my argument, this would mean that a higher degree of state

\footnotetext{
${ }^{18}$ See Stephan van Evera, Guide to Methods for Students of Political Science (Ithaca and Lindon: Cornell University Press, 1997), 11.

${ }^{19}$ van Evera, Guide to Methods for Students of Political Science, 11.

${ }^{20}$ Ibid., 13.

${ }^{21}$ Ibid.
} 
fragility in Muslim countries magnifies the causal effects between the three-level roots causes and the emergence of SJGs while a lower degree would reduce the causal impact between the two sets of independent and dependent variables. However, this does not mean that state fragility multiplies the causal relations or factors as another independent variable. Accordingly, this dissertation argues that multiple causes at the individual, group, and international levels of analysis can only factor into the formation of an SJG in countries where necessary conditions are provided by specific aspects of state fragility.

By group this dissertation refers to organized individuals who are differentiated from others by organizational characteristics, who coordinate and collaborate for a shared purpose and follow a defined strategy-making mechanism. Group, in this sense, relies on and can be defined only by the existence of an organization. ${ }^{22}$ This dissertation examines Salafi-Jihadism at the group level, and accordingly distinguishes it from Salafi-Jihadist individuals who appear in stable Western countries as "homegrown terrorists." Homegrown terrorism refers to terrorist activities conducted by "individuals born and raised or who have lived in Western countries for an extended period of time"; who are radicalized and inspired by Salafi-Jihadist ideology in their home countries in the West; "who perceive the West as a battlefield of jihad, no less critical than Iraq or Syria." ${ }^{23}$ Homegrown terrorism appears as individuals or small cells for conducting a particular attack, rather than emerging as a defined group and operate organizationally. Since the purpose of

\footnotetext{
${ }^{22}$ Paul E. Smaldino, "The Cultural Evolution of Emergent Group-Level Traits," Behavioral and Brian Sciences 35, 2014: 244.

${ }^{23}$ Manni Crone \& Martin Harrow. 'Homegrown Terrorism in the West." Terrorism and Political Violence, 23(4), 2011, 521-536; Brian Jenkins, Would-Be Warriors: Incidents of Jihadist Terrorist Radicalization in the United States Since September 112001 (Santa Monica, CA: RAND Corporation, 2010); Petter Nesser, 'Jihadism in Western Europe after the Invasion of Iraq: Tracing Motivational Influences from the Iraq War on Jihadist Terrorism in Western Europe,' Studies in Conflict \& Terrorism, 29(4), 2006, 323-42; Petter Nesser, 'How Did Europe's Global Jihadis Obtain Training for Their Militant Causes?' Terrorism and Political Violence, 20(2), 2008, 234-256; Michael Zekulin, 'Endgames: Improving Our Understanding of Homegrown Terrorism,' Studies in Conflict \& Terrorism, 39(1), 2016, 46-66.
} 
my research is to investigate the formation of groups, rather than the appearance of extremist activities by individuals, the phenomenon of homegrown terrorism is beyond the scope of this research.

Moreover, unlike scholars who examine terrorism in its broader sense, non-Salafi militant organizations that use violence for political purposes are out of the scope of this research. Thus, ideology is the major factor that distinguishes SJGs from other forms of terrorist groups. ${ }^{24}$ Ideology plays a central role in different forms of radical and terrorist organizations and SJGs are initially motivated by a specific form of ideology, a strand of the Islamist ideology which I refer to as "farenemy-centrist Salafi-jihadism." Other forms of militant organizations that are labeled as "terrorist groups" such as revolutionary movements in Peru and nationalist groups in Spain, ${ }^{25}$ suicide operations with nationalist causes such as Palestinian suicide attacks during the second intifada, ${ }^{26}$ and militant nationalist groups in Palestine and Chechnya that are fighting for the right of "external self-determination and breaking off from an occupying state"27 are out of the scope of this research.

Finally, the "state-sponsored terrorism" 28 phenomenon is beyond the scope of this dissertation. State-sponsored terrorism refers to cases that are produced or supported by a particular state for certain political and foreign policy reasons, rather than being the outcome of conditions produced by state fragility. State-sponsored terrorist groups exist "not only because certain states find value in them, but also because terrorist groups perceive the state-sponsorship to be beneficial. ${ }^{29}$ Many terrorist groups that emerged in countries such as Pakistan include state-

\footnotetext{
${ }^{24}$ Rabasa et al., Deradicalizing Islamic Extremism, 27.

${ }^{25}$ C. E. Zirakzadeh, "From Revolutionary Dreams to Organizational Fragmentation: Disputes over Violence within ETA and Sendero Luminoso," Terrorism and Political Violence 14/4 (2002): 66-92.

${ }^{26}$ Assaf. Moghaddam, "Palestinian Suicide Terrorism in the Second Intifada: Motivations and Organizational Aspects," Studies in Conflict and Terrorism 26 (2003): 65 - 92.

${ }^{27}$ L. Ali Khan, A Theory of International Terrorism: Understanding Islamic Militancy (Boston: Martinus Nijhoff Publishers, 2006), 17.

${ }^{28}$ Collins, "State Sponsored Terrorism," 134.

${ }^{29}$ Ibid., 134-136.
} 
sponsored cases and therefore are out of the scope of this research. Pakistan represents one of the most consequential sponsors of jihadism; it has created a web of terrorist organizations and supplied them intensively. ${ }^{30} \mathrm{~A}$ branch of this network is deployed to the east to support the insurgency in Indian-controlled Kashmir, including Lashkar-e-Tayeba and Jaish-e-Mohammad. The other branch, such as the Taliban and the Haqqani Network, is deployed to the west to support Pakistan's strategic depth in Afghanistan. ${ }^{31}$ Since the formation of state-sponsored jihadi organizations follows a different logic, it is beyond the scope of this dissertation. However, I believe that separate research is necessary to understand the relationship between state fragility and state-sponsorship concerning the emergence of SJGs. Inquiries addressing such complexities will add new insight in the debate on the state fragility-terrorism nexus by bringing the statesponsorship and state fragility intersections in focus.

The empirical basis of this dissertation includes two "crucial" case studies, al-Qaeda and Islamic State (IS). ${ }^{32}$ The two case studies explain how specific aspects of state fragility in Afghanistan and Iraq provided the conditions under which some individual jihadis, primarily motivated by Islamist ideology and the US post-Cold War strategy in the Middle East, organized themselves into significant SJGs like al-Qaeda and IS. The two cases are selected on the basis of the method of "crucial" case selection. ${ }^{33}$ The case selection criterion is discussed in detail in the

\footnotetext{
${ }^{30}$ Collins, "State Sponsored Terrorism," 142; Mori DocID: 800277. "Secret, Noforn [Excised - Released by US Central Command]." National Security Archive at George Washington University. http://nsarchive2.gwu.edu//NSAEBB/NSAEBB227/15.pdf; From [Excised] to DIA Washington D.C. [Excised], Cable "[Excised]/Pakistan Interservice Intelligence/ Pakistan (PK) Directorate Supplying the Taliban Forces." Secret, National Security Archive at George Washington University, October 22, 1996 http://nsarchive2.gwu.edu//NSAEBB/NSAEBB227/15.pdf; From [Excised] to DIA Washington D.C. "IIR [Excised] Pakistan Involvement in Afghanistan," Confidential, National Security Archive at George Washington University, November 7, 1996, p.2 http://nsarchive2.gwu.edu//NSAEBB/NSAEBB227/17.pdf

${ }^{31}$ Collins, "State Sponsored Terrorism," 142; Jeffrey A. Dressler, The Haqqani Network: From Pakistan to Afghanistan, Washington DC: Institute for the Study of War, 2010.

${ }^{32}$ Previously known as Islamic State of Iraq and Syria (ISIS) and Islamic State of Iraq and the Levant (ISIL).

${ }^{33}$ Charles C. Ragin, The Comparative Method: Moving Beyond Qualitative and Quantitative Strategies (Oakland: University of California Press, 2014), 36; Harry H. Eckstein, Case Studies and Theory in Political Science, in F. I. Greenstein \& N. W. Polsby (Eds.), Handbook of political science. Political science: Scope and theory 7, 94-137,
} 
methodology subsection in this chapter. The two case studies support my hypothesis, however, I do not claim they produce a general theory. Building a generalizable theory requires the findings of this case-oriented research to be followed by intensive large-N research, or to be tested by more case studies. ${ }^{34}$ Therefore, the main purpose of this dissertation is a contribution to theory development, rather than generating a general theory. ${ }^{35}$ However, despite the limitations of the empirical basis of this research, the analytical framework used in this dissertation has possible implications for studying a larger number of cases. ${ }^{36}$

\section{Conceptualizing Key Terms: The State, State Fragility, SJGs}

By the state this research refers to sovereign state, "a sovereign territorially-based entity," which primarily emerged as a result of the great transformation from the medieval to the modern era. ${ }^{37}$ When exactly this happened is a subject of debate. A few scholars believe it began by the "conciliar movement" of the fifteenth century, ${ }^{38}$ while others see its full manifestation in the concert of

1975: 118; John Gerring, "Is there a (Viable) Crucial Case Method?" Comparative Political Studies 40(3), 2007: 231-253; John Gerring \& Lee Cojocaru, "Selecting Cases for Intensive Analysis: A Diversity of Goals and Methods," Social Methods and Research 45(3), 2016: 396; Jason Seawright \& John Geering, "Case Selection Technique in Case Study Research: A Menu of Qualitative and Quantitative Options." Political Research Quarterly, 61(2), 2008: 297-298; 297-302.

34 Alexander L. George, "Case Study and Theory Development: The Method of Structured Focused Comparison," in Diplomacy: New Approaches in History, Theory and Policy, ed. Paul G. Lauren (New York: The Free Press, 1979), 45.

${ }^{35}$ Alexander L. George, "Case Study and Theory Development: The Method of Structured Focused Comparison", in Paul G. Lauren ed., Diplomacy: New Approaches in History, Theory and Policy, (New York: The Free Press, 1979), 49; Andrew Bennett, "Case Study Method: Design, Use and Comparative Advantages," in Models, Numbers, Cases: Methods of Studying International Relations, ed. Detlef F. Sprinz and Yael Wolinsky (USA: University of Michigan Press, 2004), 19-55.

${ }^{36}$ George, Case Study and Theory Development," 43-50.

${ }^{37}$ Robert Jackson, From Anarchy to Cosmopolis: Classical and Modern Thought on International Relations (New York: Palgrave, 2005), 82; Charles Tilly "War-Making and State-Making as Organized Crime," in Bringing the State Back In, ed. P. Evans, D. Rueschemeyer, and Teda Skocpol (Cambridge: Cambridge University Press, 1985), 179.

${ }^{38}$ Martin Wight, System of States, ed. Hedley Bull, (Leicester, 1977), 151; Maurice Keen, The Penguin History of Medieval Europe (London: Penguin Books, 1991), 314-21. 
Europe in the $1820 \mathrm{~s} \cdot{ }^{39}$ Most scholars, however, see the Peace of Westphalia that settled the Thirty Years War (1618-48) as the best historical marker of the development of sovereign states in Europe ${ }^{40}$ Westphalia was the most important stage in the long process that lasted for several centuries during which respublica Christiana was obliged to surrender authority to the emerging states. ${ }^{41}$ Therefore, Westphalia was not a defining moment of this political transformation, but a symbol of it. ${ }^{42}$ The main characteristic of this process was the gradual replacement of European pre-sovereign states and their "hierarchical authority structure centered on the church and its affiliated rulers" with territorially-based sovereign states. ${ }^{43}$ As a result, all territory in Europe, and ultimately all territory around the globe, was portioned by sovereign governments and placed under their independent authority. The twentieth century was the era of globalization of sovereign states. The sovereign state in this century, particularly after the end of the World War I (WWI), extended beyond Europe and reached every region of the globe.

The logic of sovereignty and sovereign states in Muslim regions was implemented by the victorious powers in the aftermath of the collapse of the Ottoman Empire in the end of WWI. The extension of sovereignty and sovereign states in Muslim societies, however, was challenged primarily by two domestic movements, namely, pan-Islamism and pan-Arab nationalism from the 1920 s to the $1960 \mathrm{~s} .{ }^{44}$ Nevertheless, due to the intensive support the newly emerged sovereign

\footnotetext{
${ }^{39}$ F. H. Hinsley, "The Concept of Sovereignty and the Relations Between States," in In Defence of Sovereignty, ed. W. J. Stankiewicz (New York: Oxford University Press, 1969), 285.

${ }^{40}$ Jackson, From Anarchy to Cosmopolis, 82.

${ }^{41}$ Ibid.

42 Ibid.

${ }^{43}$ Charles Tilly "War-Making" 179; Jenifer Milliken \& Keith Krause, "State Collapse, State Failure and State Reconstruction: Concepts, Lessons and Strategies," Development and Change 33/5 (2002): 755; Jackson, From Anarchy to Cosmopolis, 83.

${ }^{44}$ For Pan-Arab nationalism see Barry Rubin, "Pan-Arab Nationalism: The Ideological Dreams as Compelling Force," Journal of Contemporary History 26(3-4) (1991): 535-551; Tawfic Farah, Pan-Arabism and Arab Nationalism: The Continuing Debate (Boulder: Westview Press, 1987); For pan-Islamism see Ira M. Lapidus, "Islamic Revival and Modernity: The Contemporary Movements and the Historical Paradigms," Journal of the Economic and Social History of the Orient 40/4 (1997): 444-60; Ana Belen Soage, "Introduction to Political Islam," Religion Compass 3(5) (2009): 887-896. For a broader image of pan-Arabism, pan-Islamism and their relations to
} 
states in Muslim regions received from either of the two Superpowers during the Cold War and their control on the oil economy, pan-Islamic and pan-Arab transnational aspirations were marginalized or suppressed by the sovereign states. As a result, pan-Arab and pan-Islamic transnationalism lost their support in Muslim societies and the popular aspiration for the creation of a transnational Islamic or Arab state in the Middle East transmuted first into the ideal of "single state foreign policy" and subsequently into a memory. ${ }^{45}$ Regional political developments were also effective in the marginalization of Arab and pan-Islamic transnationalism. In particular, the panArab movement lost its support and influence in the aftermath of the 1967 and 1973 Arab-Israel wars and Pan-Islamism came increasingly to adopt a less political form in the aftermath of the failure of the Islamic Revolution initiated in Iran to project power in the region. ${ }^{46}$ During the IranIraq War, one state (Iran) embracing the Pan-Islamic cause fought a state (Iraq) which adopted the Pan-Arab cause, and during the Gulf War of 1991, many states of the region supported the United Nations against Iraq's pan-Arabic cause. ${ }^{47}$ This indicates that the two transnational movements/ideologies due to multiple reasons were gradually removed by the territorialized sovereign states between the 1970s and 1990s. As a result, Arab and pan-Islamic transnationalism failed to generate a successful basis for state-building in Muslim societies. This process is discussed in detail in Chapter II.

Sovereign states consist of two fundamental aspects, an institutional aspect and a functional one. The institutional aspect of the state includes the state's institutions, personality, hierarchy, and the structure through which the state functions. Thus, the institutional aspect of the state is

the Arab states in the Arab World see James J. Mellon, "Pan-Arabism, Pan-Islamism, and Inter-State Relations in the Arab World," Nationalism and Ethnic Politics 8(4), 2002: 1-15.

45 See Mellon, "Pan-Arabism, Pan-Islamism, and Inter-State Relations," 1.

46 Ibid.

${ }^{47}$ Ibid. 
basically about "what a state looks like." ${ }^{48}$ By contrast, the functional aspect of the state includes the legitimate provision of the public goods of security and services in return for taxation. ${ }^{49}$ The state, then, can be defined as a territorially specific entity that functions through various hierarchies and institutions to fulfill its fundamental duties. Those duties include maintaining effective and legitimate institutions of government, preserving the monopoly over the use of violence in a given territory, and providing security and basic services to citizens in return of taxation. ${ }^{50}$ The state's institutional aspect, then, can be examined through an assessment of its structure, institutions, and hierarchies, while its functional aspect can be measured by three variables, namely, legitimacy, authority, and capacity. ${ }^{51}$ Legitimacy provides a legitimate basis for the state's monopoly over the use of violence and its extraction of resources. Authority relates to the state's security provision and capacity for its services provision functions. These variables are discussed in major analyses and theories of the state and state formation including Webber (1919), Mann (1984), and Tilly (1985), and articulated in recent work such as Carment et al. (2010), Tikuisis and Carment (2017), and the like. ${ }^{52}$

\footnotetext{
${ }^{48}$ Michael Mann, "The Autonomous Power of the State: Its Origins, Mechanisms and Powers," European Journal of Sociology 25(2), 1984, 185-213.

${ }^{49}$ Robert Jackson, "Surrogate Sovereignty? Great Power Responsibility and 'Failed States," Institute of International Relations, The University of British Colombia, (Working Paper No. 25, November 1998), 2; Paul Collier, "The Political Economy of State Failure," Oxford Review of Economic Policy, 2009, Vol. 25 No. 2: 220. ${ }^{50}$ Max Weber, The Vocation Lectures, Rodney Livingstone trans., and David Owen and Tracy Strong eds., (Indianapolis, Cambridge: Hackett Publishing Company, 1919/2004); David Owen and Tracy Strong eds., (Indianapolis, Cambridge: Hackett Publishing Company, 1919/2004); Tilly, "War Making and State Making as Organized Crime;" Mann, "The Autonomous Power of the State;" David Carment, Stewart Prest, and Yiagadeesen Samy. Security, Development, and the Fragile State: Bridging the Gap between Theory and Policy (London: Routledge 2010); Peter Tikuisis and Carment, "Categorization of States beyond Strong and Weak," Stability: International Journal of Security and Development 6(1): 2017, 1; Stewart Patrick, Weak Links: Fragile States, Global Threats and International Security (NY: Oxford University Press, 2011), 8.

${ }^{51}$ Carment et al. Security, Development, and the Fragile State, 85.

${ }^{52}$ Weber, The Vocation Lectures; David Owen and Tracy Strong eds., (Indianapolis, Cambridge: Hackett Publishing Company, 1919/2004); Tilly, "War Making and State Making as Organized Crime;" Mann, "The Autonomous Power of the State;" Carment et al., Security, Development, and the Fragile State;" Patrick. Weak Links," 8.
} 
Weber (1919) defines the state as a form of human community that lays claim to the monopoly of legitimate physical violence within a particular territory. ${ }^{53}$ Weber emphasizes that all other organizations, within a state, can use violence "only insofar as the State permits them to do so." 54 Therefore, the state, according to Weber, is "the sole source of the right" to use violence in a given territory. ${ }^{55}$ Moreover, Weber believes that in order to prevent social disorder and anti-state uprisings, the use of violence by the state has to be legitimate and people should obey it primarily by consent, rather than coercion. Thus, a durable state requires what Weber calls a "legitimate authority." ${ }^{, 6} \mathrm{He}$ identifies three major sources for a "legitimate authority," namely, traditional, charismatic and rational-legal. ${ }^{57}$ The traditional rule is based on costumes and traditions and is exercised by patriarchs and patrimonial rulers. ${ }^{58}$ The charismatic rule is based on the charisma of a leader and is exercised by individuals such as "prophets, the warlords, the great demagogues and party leaders." ${ }^{\prime 59}$ And the rational-legal authority is based on "impersonal rational rules, or a person's willingness to carry out statutory duties obediently." ${ }^{60}$ According to Weber, this type of authority is practiced through the validity of legal status which Weber describes as the characteristic of modern states. ${ }^{61}$

Likewise, Tilly (1985) describes the state as a relatively centralized, differentiated organization the officials of which claim control over the chiefly concentrated means of violence within a population inhabiting a territory. ${ }^{62}$ Thus, Tilly's conception of the state is similar to

\footnotetext{
${ }^{53}$ Weber, The Vocation Lectures, 33.

${ }^{54}$ Ibid.

${ }^{55}$ Ibid.

${ }^{56}$ Ibid., 34.

${ }^{57}$ Ibid.

${ }_{58}^{58} \mathrm{Ibid}$.

${ }^{59}$ Ibid.

${ }^{60}$ Ibid.

${ }^{61}$ Ibid.

${ }^{62}$ Tilly, "War Making and State Making as Organized Crime," 170
} 
Weber's political organization that lay claim to the monopoly of violence in a particular territory. ${ }^{63}$ However, Tilly goes beyond Weber's general arguments and elaborates different elements of the state more concretely. The state, according to Tilly, carries out four major duties: "war-making" or the elimination of the state's external enemies, "state-making" or the elimination of the state's internal rivals, protection or the elimination/neutralization of the enemies of its clients, and extraction or acquiring the means of carrying out the first three activities. ${ }^{64}$ War-making, according to Tilly, "yields armies, navies, and supporting services," state-making "produces durable instruments of surveillance and control within the territory," protection relies on the organization of war-making and state-making and functions through specific state institutions such as courts and representative assemblies, and extraction brings fiscal and accounting structures into being. ${ }^{65}$ Yet, Tilly believes that the state's all four duties depend on the state's tendency to monopolize the concentrated means of coercion. Therefore, the main purpose of those who monopolize the means of violence is primarily the elimination of their internal rivals which strengthens their ability to extract resources and protect their supporters. ${ }^{66}$ Accordingly, Tilly's theorization of the state includes two specific pillars: first, the concentration and the particular combination of capital and coercion within the state, and second, the interplay of war-making states on the international stage. $^{67}$

Finally, in conceptualizing the sovereign state, Mann (1984) distinguishes between the characteristics and the functions of the state. In doing so, he organizes the main features of the state into two categories, an institutional category which includes a number of elements that define

\footnotetext{
${ }^{63}$ Weber, The Vocation Lectures, 33.

${ }^{64}$ Tilly, "War Making and State Making as Organized Crime," 181.

${ }^{65}$ Ibid.

66 Ibid.

${ }^{67}$ Charles Tilly, Coercion, Capital, and European States, AD 990-1990 (Cambridge: Basil Blackwell, 1990), 17-20.
} 
"what a state looks like," and a functional category that describes "what a state does." institutional aspect of the state includes the state's institutions, personality, and a defined territory, while its functional aspect includes activities that a state is assigned to fulfill. ${ }^{69}$ Mann (1984) characterizes three bases that determine the state's function, namely, ideological, military and economy. ${ }^{70}$ The ideology deals with the legitimacy, the military is about authority, and economy relates to the capacity of the state. These three measures determine whether a political entity enjoys statehood or not.

Statehood or stateness, in this sense, refers to a state's functions rather than its characteristic or nature. Thus, degree of a state's capability in conducting its fundamental functions is defined as "statehood" or "stateness" which is measured by the three variables of legitimacy, authority, and capacity. ${ }^{71}$ State fragility denotes different levels of stateness ${ }^{72}$ with the two having a counter relationship. It means that states with a higher degree of stateness represent a lower degree of fragility and vice versa. In other words, fragile states suffer from a lower degree of authority, legitimacy, and capacity than highly functioning states. States that indicate weakness in one or all three measures of stateness are considered fragile in those specific areas. For instance, states that lack legitimacy suffer from poor popular support and are prone to internal uprisings and insurgency, and states that lack authority do not have sufficient physical force to control its population, territory and borders, and to provide security and justice to its citizens.

\footnotetext{
${ }^{68}$ Mann, “The Autonomous Power of the State," 185-213.

${ }^{69}$ Ibid., 188.

70 Ibid.

${ }^{71}$ Carment et al., Security, Development, and the Fragile State, 85; Tikuisis and Carment, "Categorization of States beyond Strong and Weak," 1.

72 Pinar Bilgan and Adam David Morton, “Historicising Representations of 'Failed States': Beyond the Cold-War Annexation of the Social Sciences?” Third World Quarterly 23/1 (2002): 56.
} 
Considering this conceptualization, legitimacy refers to the extent to which a state enjoys popular support internally and acceptance internationally. ${ }^{73}$ Legitimacy, in this sense, refers to both internal and external recognition. Likewise, authority refers to a state's capability in exercising what Weber calls the monopoly over the use of legitimate violence in its territory. ${ }^{74}$ Authority, in this sense, refers to the state's defense and security institutions and its ability to provide security within its sovereign borders, enact legislation over its population, and provide a secure environment to its citizens. ${ }^{75}$ Finally, capacity includes the human and financial resources that a state has at its disposal. ${ }^{76}$ Capacity, in this sense, refers to the availability of resources, the state's economic size, and the state's ability to acquire the necessary means of governance and provide basic services to its citizens. ${ }^{77}$

It is worth noting that, as Jackson (1998) highlights, state fragility refers to the fragility of empirical, not juridical, statehood. ${ }^{78}$ In other words, fragile states refer to states that are territorially international realities but domestically they fail to conduct their core roles of providing the public goods of security, justice, and services. ${ }^{79}$ Regardless of their internal fragility, highly fragile states are still international realities. As Jackson (1998) articulates, fragile states do not lose their juridical recognition in the international system because "firstly, the procedural norms of equal sovereignty and non-intervention (juridical statehood) are observed regardless of domestic conditions-in accordance with the UN Charter - Article 2 (4)" and "secondly, the substantive qualification for international recognition and UN membership (empirical statehood) has been

\footnotetext{
${ }^{73}$ Carment et al., Security, Development, and the Fragile State, 85.

${ }^{74}$ Ibid., 88.

${ }^{75}$ Ibid., 86 .

${ }^{76}$ Ibid.

${ }^{77}$ Ibid.

${ }^{78}$ Jackson, "Surrogate Sovereignty," 3.

${ }^{79}$ Ibid.
} 
disregarded -Article 4 (1) which declares that member states are able and willing to carry out their Charter obligations" that presuppose the capabilities of empirical statehood. ${ }^{80}$

Although state fragility is not a post-Cold War phenomenon, it has been more evident since the end of the bipolar international system. ${ }^{81}$ According to Carment (2003) "many states in the world have failed, are failing or will fail largely because the support they received from one or both of the superpowers as proxy allies during the Cold War withered away after the fall of the Berlin Wall." 82 Following the end of the Cold War and the collapse of dozens of the Third World states, terms such as failed states, failing states, weak states, collapsed states and the like entered the political science literature. These terms initially "emerged as ad hoc conceptual responses to what seemed to be new sorts of armed conflicts and problems in the wake of the Cold War." 83 The term state fragility, was constructed as an inclusive concept by scholars who aimed to incorporate these terms within a single theoretical framework that constitutes terms such as failed, collapsed, and weak states as its subsets. ${ }^{84}$ Accordingly, every term used above only describes a specific degree of fragility, however, they are not interchangeable. ${ }^{85}$ Recent scholarly work indicates a consensus over the usage "state fragility" as an inclusive term. ${ }^{86}$ Moreover, the term today is broadly used by international research institutions such as the Center for Systemic Peace (CSP), the Fund for Peace (FFP), and the Brookings Institute. The usage of state fragility in this research is informed by the inclusiveness of the term and the broad scholarly agreement upon it.

\footnotetext{
${ }^{80}$ Ibid.; M. J. Peterson, Recognition of Governments: Legal Doctrine and State Practice, 1815-1995 (London: Macmillan, 1997), 68-71.

${ }^{81}$ David Carment, “Assessing State Failure: Implications for Theory and Policy," Third World Quarterly 24/3 (2003): 407; Jackson, "Surrogate Sovereignty?" 3. 
The case studies of this dissertation include two typical instances of state fragility. A review of the trends of fragility, since data is available, shows that the two countries have steadily received the highest fragility scores. According to the Center for Systemic Peace's (CSP) fragility index, which provides trends of state fragility in the world since 1995, Afghanistan in the 1990s, and Iraq in the 2000s experienced a very high level of fragility on all three measures of statehood. The CSP scores "state fragility" on effectiveness and legitimacy of security, political, economic and social performances of states. The CSP's State Fragility Index, then, combines scores on the four indicators and ranges from 0 (no fragility) to 25 (extreme fragility). ${ }^{87}$ According to this data, Afghanistan received consistently the highest scores of 25 and 24 from 1995 to $2001{ }^{88}$ This was the timeframe in which al-Qaeda emerged. Likewise, the emergence of IS in post-Saddam Iraq exemplifies a typical case study of the relationship between state fragility and the rise of SJGs. According to CSP data, Iraq in the aftermath of the April 2003 invasion suffered severely from high fragility particularly in areas of security and political legitimacy and effectiveness. Although the country's political legitimacy enhanced by two points in 2003 and 2004, it subsequently dropped to the end after $2005 .{ }^{89}$ Although low political and security legitimacy and effectiveness was the legacy of the post-Gulf War (1990-1991) developments in Iraq, it was intensified by the occupation and its subsequent domestic and regional consequences. According to another state fragility index, the FFP's Fragile States Index which evaluates state fragility since 2005, Iraq was ranked as one of the top-ten most fragile states from 2005 to $2014 .{ }^{90}$ This was the time period the Iraq-based insurgency developed to IS as a uniform SJG with a global objective. Examination of

\footnotetext{
${ }^{87}$ Monty G. Marshall \& Gabrielle Elzinga-Marshall, Global Report 2017: Conflict, Governance, and State Fragility (Vienna, VA: Center for Systemic Peace, 2017), 51-54.

${ }^{88}$ Center for Systemic Peace, State Fragility Index and Matrix 1995-2016 http://www.systemicpeace.org/inscrdata.html

${ }^{89}$ Ibid.

${ }^{90}$ See The Fund For Peace, Fragile States Index: Iraq, http://fundforpeace.org/fsi/country-data/
} 
the rise of al-Qaeda and IS, respectively in Afghanistan and Iraq, would exemplify the relationship between state fragility and the rise of SJGs. The two case studies explore aspects and trajectories of state development and state fragility in the two countries and the reasons they provided the conditions necessary for the emergence of al-Qaeda and IS. A detailed overview of state formation in Afghanistan and Iraq and the trajectories and trends of state fragility in the two countries is provided in Chapters IV \& VI.

Salafi-Jihadi Groups: By SJGs I refer to organizations that follow Salafi-Jihadism as their core ideology. They construct a religious justification for violent means for reaching a defined end, which is the establishment of an Islamic state as the "nucleus of a new international order."91 Conceptually, Salafi-jihadism is a particular strand of Salafist, also known as Islamist, ideology which provides a particular interpretation of Islam and global politics. It differs from other Islamist schools on the basis of its particular interpretation of the four key elements of the Islamist ideology: the definition of an international political problem, the construction of an enemy that causes the problem, the characterization of a method to resolve the problem, and the definition of an ultimate goal. The particularistic interpretation of these elements are evident in almost all SJGs declarations and statements. ${ }^{92}$

\footnotetext{
${ }^{91}$ Tibi, Islamism and Islam.

${ }^{92}$ See, for instance, Abu Mohammad Al-Adnani, ISIS Spokesman Declares Caliphate, Rebrands Group as 'Islamic State,' SITE Intelligence Group. Retrieved from https://news.siteintelgroup.com/Jihadist-News/isisspokesmandeclares-caliphate-rebrands-group-as-islamic-state.html; Ayman Al-Zawahiri, His Own Words: Translation and Analysis of the Writings of Dr. Ayman al Zawahiri, Translation and Analysis by Laura Mansfield, (Old Tappan, NJ: TLG, 2001a); Ayman Al-Zawahiri, "Knights Under the Prophet's Banner," in G. Kepel, \& J-P. Milelli (Eds.), Al-Qaeda in Its Own Words, Translated by P. Ghazaleh, 191-206 (Cambridge, MA: Harvard University Press, 2001b); Osama Bin Laden, "Declaration of War Against the Americans Occupying the Lands of the Two Holy Places," ACT for America, Retrieved from http://www.actmemphis.org/usama-bin-laden-1996declaration-of-war-against-the-americans.pdf; Osama Bin Laden, et al, World Islamic Front Statement: Jihad Against Jews and Crusaders," Federation of American Scientists, 1998, Retrieved from http://fas.org/irp/world/para/docs/980223-fatwa.htm
} 
Historically, Salafi-Jihadism is divided into two main streams, a majority school which mainly follows a near-enemy-centrist strategy, and a minority branch which is basically farenemy-centrist. From the 1970s until the end of the Cold War, the far-enemy-centrists were marginalized when near-enemy-centrism was the most popular narrative of jihadism in Islamist communities. ${ }^{93}$ The near-enemy-centric Salafi-Jihadism of this period defined the secular rule over the Muslim societies as the problem, and the "apostatic regimes" in Muslim countries as the enemy. ${ }^{94}$ It further defined a "domestic and defensive" jihad as the method, and considered the replacement of the secular regimes with sharia-based Islamic states as the goal. ${ }^{95}$ Accordingly, near-enemy-centrism implicitly recognized the territoriality of the sovereign states in Muslim regions and aimed at a transfer of power within the context of sovereign states, rather than prioritizing transnationalism. However, with the transformation of the international system at the end of the Cold War, far-enemy-centrism replaced the former as the most attractive approach in Salafi communities redefining the core elements of the ideology. ${ }^{96}$ In the new narrative, "the American domination of the Muslim lands" was defined as the problem, the United States and its allies were characterized as the enemy, a global jihad was considered as the method, and the establishment of a transnational Islamic state was defined as the ultimate goal. The four key elements of this ideology are clearly expressed in both al-Qaeda and Islamic State's declarations and its leadership's statements and interviews. ${ }^{97}$

The sudden popularity of far-enemy-centrism was the outcome of the experiences of a generation of Salafi-jihadis who were inspired primarily by the "rhetoric of an absolutist and

\footnotetext{
93 Gerges, The Far Enemy, 43-55.

94 Ibid.

${ }^{95}$ Choueiri, Islamic Fundamentalism, 223-236; Gerges, The Far Enemy, 43-55;

${ }^{96}$ Ibid., 223-236.

${ }^{97}$ See Al-Adnani, ISIS Spokesman Declares Caliphate; Al-Zawahiri, His Own Word; Al-Zawahiri, "Knights Under the Prophet's Banner;" Bin Laden, "Declaration of War;” Bin Laden, et al, "World Islamic Front Statement."
} 
textualist Islamist ideology (Qutbian doctrine)," radicalized by the Afghan war in the 1980s, and motivated for a global jihad due to personal experiences and the witnessing of the Muslim communities" "bitter experiences" in the early 1990s. ${ }^{98}$ However, despite the recent popularity of far-enemy-centrism and its strict strategic distinction from near-enemy-centrism, the two strands are interconnected and enjoy a similar ideological basis. Therefore, contemporary SJGs, although prioritizing far-enemy-centrism as the core strategy, encompass the elements of both the strands of Salafi-jihadism. While prioritizing far-enemy centrism, SJGs rely on elements of near-enemycentrism when it is necessary and fruitful. For instance, while organizations such as al-Qaeda are basically far-enemy-centrist, they are interconnected with groups such as the Taliban that prioritize near-enemy-centrism. Other SJGs such as IS encompass both far- and near- enemy centrism. Moreover, while al-Qaeda and IS follow the far-enemy-centric goal of re-establishing the Caliphate, they simultaneously support campaigns against false Muslim rulers (e.g. in Afghanistan, Saudi Arabia, Egypt, Uzbekistan, etc.). ${ }^{99}$ Statements from Bin Laden, Zawahiri, Zarqawi, Sayf al Adl, and other al-Qaeda leaders display the uncompromising commitment of Salafi-Jihadist leaders to the ideological agenda of the creation of an Islamic state and the strategic prioritization of the enemy. ${ }^{100}$ Therefore, while far-enemy-centrist in essence and ideology, SJGs take nearenemy-centrist approaches when it is required.

SJGs, in general, are distinguished from the broader Salafi/Islamist movement due to different procedural and historical factors and experiences. Salafism, both as an ideology and a movement, primarily emerged in the late thirteenth and early fourteenth centuries with the slogan

\footnotetext{
${ }^{98}$ Gerges, The Rise and Fall of Al-Qaeda, 67; Murden, Islam, the Middle East and the New Global Hegemony, 197.

${ }^{99}$ Rohan Gunaratna. Inside al-Qaeda: Global Network of Terror (New York, NY: Colombia University Press, 2002), 55 .

${ }^{100}$ Christopher M. Blanchard. Al-Qaeda: Statements and Evolving Ideology. CRS report for Congress. 2007, 15. Retrieved from https://fas.org/sgp/crs/terror/RL32759.pdf
} 
of defending Muslim lands from the Mongol invaders. ${ }^{101}$ An historical analysis of this movement and its development to the present time is conducted in Chapter II. Salafism, in the $20^{\text {th }}$ century divided into two major strands, political Salafis (politicos) and Salafi-Jihadis, also labeled as Jihadi Salafis. ${ }^{102}$ Political Salafis transformed into modern political parties such as the Egyptian Muslim Brotherhood and the Tunisian al-Nahda which prioritized doing politics within the framework of sovereign states and through peaceful means. Salafi-jihadis turned transnational, resisting the postWWI geopolitics of the Muslim world, prioritizing violent campaigns against both the sovereign states and international order, and aiming for the restoration of the Caliphate.

This dissertation considers four major characteristics that distinguish SJGs from the broader Islamist/Salafist groups which I describe as Political Islamist Groups (PIGs). First SJGs prioritize transnationalism, both in terms of organization and objectives. Following the end of the Cold-War, while PIGs remained committed to the struggle within the framework of particular Muslim sovereign states, SJGs considered the entire globe to be their legitimate field of operation. Therefore these groups were formed of citizens belonging to different countries and followed the transnational objective of the formation of an Islamic state as the nucleus ${ }^{103}$ of a new international order. While PIGs are interested in national politics, SJGs are not exclusively interested in local or national political programs and have set their sights on confronting the world and its nationstate-based order. ${ }^{104}$ Second, SJGs use violence as the primary means of action. While PIGs "have come to accept, albeit with a varying degree of open commitment, the idea of gaining power by peaceful means including elections whenever they become available," SJGs are basically armed

\footnotetext{
${ }^{101}$ Palmer, and Palmer, Islamic Extremism, 12-13; Corbin, Al-Qaeda, 11; Christina Hellmich, "Creating the Ideology of al-Qaeda: from Hypocrites to Salafi-Jihadists," Studies in Conflict \& Terrorism 31 (2008): 114-15.

${ }^{102}$ Roel Meijer, Global Salafism: Islam's New Religious Movement (New York: Columbia University Press, 2009).

${ }^{103}$ On this see Tibi, Islamism and Islam.

${ }^{104}$ Choueiri, Islamic Fundamentalism, 223; Bob de Graaff, "The Impossibility of a Global Counter Terrorism Strategy, or the End of the Nation-State," in Critical Perspectives on Counterterrorism, ed. Lee Jarvis and Michael Lister (New York and London: Routledge, 2015), 13.
} 
with a global strategy based on violent confrontations and terrorist attacks. ${ }^{105}$ The third element that distinguishes the two categories of Islamist groups is their different interpretation of jihad as a method of struggle. The definition of jihad for PIGs is jihad as a "defensive policy against foreign occupation and globalization and as a tool for preserving the community." ${ }^{106}$ By contrast, jihad for SJGs is "equated with jihadism, an offensive ideology." "107 Jihad, in this sense, "becomes equated with an ideology that uses violence as a method of struggle for achieving the ultimate goal of a global victory and the formation an Islamic caliphate. ${ }^{108}$ Finally, SJGs have a relatively "higher degree of intensity in commitment to ideology and willingness to sacrifice" than PIGs. ${ }^{109}$ Chapter II examines the characteristics and historical development of SJGs in detail.

\section{Analytical Framework}

This research, initially, draws on the "levels of analysis" theory of IR which originally arose from scholarly debate on the causes of war and peace in international politics. ${ }^{110}$ The theory was subsequently developed by IR scholars into an analytical framework which investigates causes of international phenomena at the individual, group, and international levels. ${ }^{111}$ The term "levels of analysis" was first used by Singer (1961) who primarily formulated the structural causes of international events on two levels, the state, and the international system. ${ }^{112}$ Although Waltz

\footnotetext{
${ }^{105}$ Choueiri, Islamic Fundamentalism, 223; Bob de Graaff, "the Imposibility," 13.

${ }^{106}$ Choueiri, Islamic Fundamentalism, 224.

107 Ibid.

${ }^{108}$ Ibid., 224-25.

${ }^{109}$ Gabriel Ben-Dor and Ami Pedahzur, "The Uniqueness of Islamic Fundamentalism and the Fourth Wave of International Terrorism," in Religious Fundamentalism and Political Extremism, ed. in Leonard Weinberg and Ami Pedahzur (London: Frank CASS and Co Ltd., 2004), 80.

${ }^{110}$ Benjamin A. Most and Harvey Starr, Inquiry, Logic and International Politics (Columbia: University of South Carolina Press, 1989), 24-25; David J. Singer, "The Level of Analysis Problem in International Relations," World Politics 14(1), Oct. 1961: 77-92; Kenneth N. Waltz, Theory of International Politics, Boston: McGrawhill, 1979.

${ }^{111}$ T.F. Homer-Dixon, On the threshold: Environmental change as causes of acute conflict, International Security, 16(2), 1991: 76-116; Ibrahimi, Theory of the Rise of al-Qaeda.

112 Singer, "The Level of Analysis Problem in International Relations."
} 
(1954) had already developed the "three images of international politics" - man, the state, and the international system - he had not used the "levels of analysis" term in his early work. The levels of analysis framework was developed in Waltz's famous work, "Theory of International Politics" originally published in 1979. Following Waltz's popular work, the framework became a focal point of debate in IR. Among others, Most and Starr (1989) developed it into a framework which includes two flexible sets of variables, including variables belonging to willingness and variables belong of opportunity (Most and Starr 1989, 24-25). The first level of analysis, in this work, includes individual actors and their willingness to act, the second level belongs to a group of actors and the opportunities that motivate their behavior, and the third level includes the context that determines actors' behavior. ${ }^{113}$ Thus, in Most and Starr's work, the second level of analysis becomes more flexible than in Waltz's analysis of the state. Accordingly, Most and Starr (1989) transformed the traditional levels of analysis framework from a model that includes the individual, state, and international levels into a framework composed of individual, group, and international levels. Considering the development of the levels of analysis framework, scholars have added "group of actors" at the second level of analysis. Homer-Dixon (1991), for instance, categorizes the three levels of analysis into individual, group, and international levels. ${ }^{114}$ At the individual level, individual psychology and motivation are used to explain "civil strife, including strikes, riots, revolutions, and wars." ${ }^{115}$ According to Homer-Dixon, scholars at this level of analysis "suggest that individuals become aggressive when they feel frustrated by something or someone they believe is blocking them from fulfilling a strong desire." ${ }^{\prime 16}$ At the group level, Homer-Dixon

\footnotetext{
${ }^{113}$ Most and Starr, Inquiry, Logic and International Politics, 35-36.

114 Thomas F. Homer-Dixon, "On the Threshold: Environmental Change as Causes of Acute Conflict," International Security 16(2), fall 1991: 76-116.

${ }^{115}$ Homer-Dixon, "On the Threshold," 104.

${ }^{116}$ Berkowitz, Leonard. Aggression: A Social Psychological Analysis. New York: McGraw-Hill, 1962; Dolard, John, et al. Frustration and Aggression. New Haven: Yale University Press, 1939; Homer-Dixon, "On the Threshold," 104-105.
} 
uses group identity variables such as nationalism, ethnicity, ideology, and religion to explain causes of conflicts. ${ }^{117}$ And finally, at the international level of analysis, he considers the international system or "external constraints" as a determining force behind the occurrence of international events such as conflicts and wars. ${ }^{118}$ Theories belong to this level of analysis suggest that external constraints can encourage and even compel actors to engage in war. ${ }^{119}$

The levels of analysis model not only includes causes, correlations, and explanations of international phenomena at all three levels but also considers the significance of relationships among different levels. ${ }^{120}$ Drawing on this analytical framework, this dissertation argues that individual jihadis' "quest for significance" (at the individual level), Salafi-Jihadism as a group ideology (at the group level), and the United States unipolar policies in the Muslim world (in the international level) are the root causes of SJGs. It is worth noting that the international level cause, in this dissertation, is only discussed under unipolarity conditions. Therefore, the causal relations between international factors and the emergence of SJGs are explained in a particular scope affected by the nature of the international system, in which the United States, as the sole great power, enjoys a "global defense perimeter" and a "superlative power-projection ability" in the world. ${ }^{121}$ Unipolarity, in this sense, produced an international condition under which the sole great power's policies have particular impact on international peace and security. Although there is no

\footnotetext{
${ }^{117}$ Henri Tajfel, Human Groups and Social Categories: Studies in Social Psychology. Cambridge: Cambridge University Press, 1981; M. Sherif, Group Conflict and Cooperation: Their Social Psychology. London: Routledge, 1966; Homer-Dixon, "On the Threshold," 105.

${ }^{118}$ Homer-Dixon, "On the Threshold," 105.

${ }^{119}$ Waltz, Theory of International Politics; Nazli Choucri \& Rrobert North, Nations in Conflict. San Francisco, CA: Freeman, 1975.

${ }^{120}$ Ibrahimi, Theory of the Rise of al-Qaeda; Most and Starr, Inquiry, Logic and International Politics, 24-25; Owen Temby, "What are levels of analysis and what do they contribute to international relations theory," Cambridge Review of International Affairs, 28(4), 2015: 721-742.

${ }^{121}$ Nuno Monteiro, Theory of Unipolar Politics (New York: Cambridge Univrsity Press, 2014), 1-3.
} 
scholarly agreement on the direct impact of unipolarity on international instability, ${ }^{122}$ evidence shows that unipolar policies had a determinate impact both on the formation of SJGs such as IS and al-Qaeda and on shaping the direction of factors at other levels of analysis toward this specific outcome. $^{123}$

Overall, the levels of analysis framework is chosen as the "pre-theoretical basis" for this research, and state fragility is added to the framework as a condition variable. Drawing on the "levels of analysis framework," this dissertation first integrates the causes of the emergence of alQaeda and IS into a single model which searches not only for causes and explanations at, and across, all three levels of analysis, but also considers the significance of the relationship and interaction among different levels. ${ }^{124}$ Figure I indicates a general causal model of the rise of SJGs.

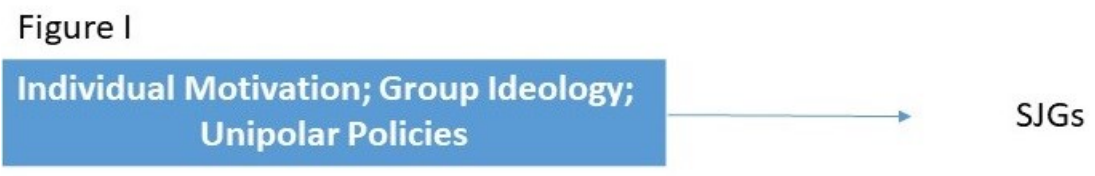

This model indicates that individual jihadis" "quest for significance" and their sense of revenge (at the individual level), the Salafi-Jihadist ideology (at the group level), the transformation of the international system from bipolarity to unipolarity and the sole great power's foreign and military policies under unipolarity conditions (at the international level) are the major determinants of the rise of SJGs. ${ }^{125}$ These drivers force individuals to join and remain as members of a terrorist

\footnotetext{
${ }^{122}$ Monteiro, Theory of Unipolar Politics; Wohlfoth, William C. "The Stability of Unipolarity." International Security 24(1), 1999: 5-41.

${ }^{123}$ Ibrahimi, Theory of the Rise of al-Qaeda.

${ }^{124}$ Most and Starr, Inquiry, Logic and International Politics, 24-36.

${ }^{125}$ Bin Laden, et al, "World Islamic Front Statement;" Post, "The Psychological Dynamics of Terrorism," 17-18; Horgan, Horgan, "Understanding Terrorist Motivation," 107-109; M. Dugas \& A. W. Kruglanski, A. W. The Quest for Significance Model of Radicalization: Implications for the Management of Terrorist Detainees, Behavioral Sciences and the Law, 32, 2014, 424-427; Kruglanski, A. W., \& Orehek, E., The Role of the Quest for Personal
} 
organization. ${ }^{126}$ Regarding the rise al-Qaeda and IS, for instance, "giving a sense of power to the powerless" and a sense of revenge (at the individual level), Islamist ideology (at the group level), and the United States' unipolar policies in Muslim world (at the international level) could be considered as causal determinants of the formation of the two organizations. ${ }^{127}$ Taking this causal model as an analytical basis of this dissertation in consideration, I admit that different factors on all three levels play a causal role in the rise of SJGs. However, I do not argue, in this dissertation, that these independent variables can comprehensively explain the rise of SJGs. Rather, my core argument is that the causal relationship between these variables and the emergence of SJGs is conditioned with aspects of state fragility in Muslim majority countries. In other words, specific aspects of state fragility in Muslim majority countries magnified the relationship between causes at three levels of analysis and the rise of SJGs. Thus, drawing on the levels of analysis framework, initially, I organize the root causes of the emergence of SJGs in a unidirectional model as above. However, in order to develop the model of the rise of SJGs in a more sophisticated stage, I add "state fragility" as a condition variable ${ }^{128}$ to the unidirectional causal framework. This model would includes both causes and conditions of the rise of SJGs. Figure II indicates the general model of the emergence of SJGs.

Significance in Motivating Terrorism. In J. Forgas, A. W. Kruglanski, \& K. Williams (Eds.), The Psychology of Social Conflict and Aggression: 153-166 (New York, NY: Psychology Press, 2011); Palmer, and Palmer, Islamic Extremism, 147.

${ }^{126}$ Post, The Mind of the Terrorist, 4.

${ }^{127}$ For detailed explanation about the United States post-Cold War strategy see Nuno P. Monteiro, Theory of Unipolar Politics, (New York: Cambridge University Press, 2014). And for the role of the United States post-Cold War strategy in the emergence of SJGs see Gerges, The Rise and Fall of Al-Qaeda, 67; Murde, Islam, the Middle East and the New Global Hegemony 43, 195-97; Zunes, "The United States: A Hegemon Challenged," 73. For explanation about the role of religion and ideology in the rise of terrorist groups see Choueiri, Islamic

Fundamentalism; Gerges, The Far Enemy; Gerges, The Rise and Fall of Al-Qaeda; Patrick, Weak Links, 63; Mark Sedgwick, Al-Qaeda and The Nature of Religious Terrorism, Terrorism and Political Violence 16/4 (2004), 795; Tibi, Islamism and Islam.

${ }^{128}$ Van Evera, Guide to Methods for Students of Political Science, 11. 
Figure II

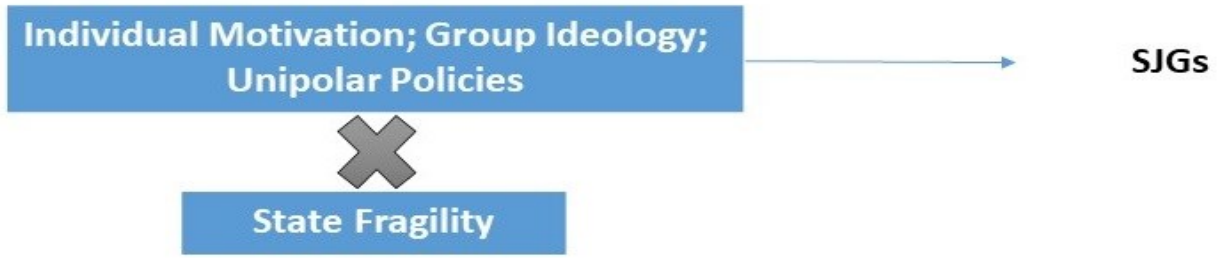

This framework develops the argument that SJGs are the outcome of causes at three levels of analysis, as articulated. However, the causal relationship is conditioned by state fragility, with different aspects of state fragility magnifying the causal effects and facilitating the practical emergence of a SJG. Evidence supports the argument that most SJGs emerged in highly fragile states (e.g., al-Shabaab in Somalia; al-Qaeda in Afghanistan; AQAP in Yemen; IS in Iraq and Syria, and Boko Haram in Nigeria, Niger, and Chad). Thus, SJGs emerged in countries in which sovereign states fell short in at least two out of the three measures of stateness. Lack of authority, in particular, is the most determinant aspect of state fragility which persisted in almost all cases of the rise of a SJG. Poor legitimacy, particularly when twinned with lack of authority, becomes another decisive condition for the emergence of SJGs. However, lack of legitimacy, or the legitimacy trap, ${ }^{129}$ alone is not a sufficient condition for the formation of SJGs. Poor legitimacy in cases such as Saudi Arabia, did not lead to the formation of any SJG. Therefore, thousands of individual Saudi jihadis left the country to form or join a group in countries which fell short in other measures of stateness, particular lack of authority including Afghanistan and Iraq. ${ }^{130}$

\footnotetext{
129 Shinichi Takeuchi, Ryutaro Murotani, and Keiichi Tsunekawa, "Capacity Traps and Legitimacy Traps: Development Assistance and State Building in Fragile Situations," in Catalyzing Development: A New Vision for Aid, ed. H. Kharas et al., 127-154 (Washington D.C: Brookings Institute Press, 2011).

${ }^{130}$ On Saudi jihadis in Iraq, for instance, see Nawaf Obaid and Anthony Cordesman, Saudi Militants in Iraq: Assessment and Kingdom's Response (Washington D.C.: Center for Strategic and International Studies, September 19, 2005), 4-7; Thomas Hegghammer, 'Saudis in Iraq: Patterns of Radicalization and Recruitment,' Cultures and Conflicts 2008, 11; Faiza Saleh Ambah, "Saudi Fighters Cross Border to Kill Infidels," Washington Times, August 31, 2003 http://www.washingtontimes.com/news/2003/aug/31/20030831-121933-2108r/; Shaista Aziz, "Saudi Fighters 'Join Resistance' in Iraq," Al-Jazeera, October 28, 2003 http://www.aljazeera.com/archive/2003/10/2008410141418821563.html
} 
Therefore, lack of authority and legitimacy, together, can be considered as the decisive condition of the formation of SJG. Lack of or poor capacity, although apparent in almost all cases of the formation of SJGs, is not a determinate factor. Lack of capacity enhances the chance of the rise of a SJG in countries that simultaneously experience high fragility in areas of legitimacy and authority, but it is not a decisive condition alone. In the case of al-Qaeda, for instance, lack of capacity was a serious factor, while it played a small role in the case of IS. Since the empirical basis of this dissertation includes two cases, al-Qaeda and IS, the analytical framework for each case is developed separately. Development of these particular models follows the same general logic, as articulated earlier in this section: First, drawing on the levels of analysis framework, I organize causal models of the two cases and, second, I develop the framework into a more sophisticated model by adding state fragility as a condition variable.

Regarding al-Qaeda, I consider bin Laden and his inner circle's personal motivation/willingness to fight against the "remaining superpower," their sense of revenge and their "quest for significance" as the individual level causes of the emergence of this group. ${ }^{131}$ Salafi-Jihadism is considered as the main cause of the formation of al-Qaeda at the group level. And finally, the transformation of the international system from bipolarity to unipolarity and the United States' unipolar policies in the Muslim world are considered as determinant causes of the emergence of al-Qaeda at international level. Figure III indicates the general causal model of the emergence of al-Qaeda.

Figure III

Individual Motivation; Salafi-Jihadism;

Unipolar Policies

Al-Qaeda

${ }^{131}$ Gerges, The Rise and Fall of al-Qaeda, 147. 
Regarding IS the same individual, group, and international level variables are considered as independent causes of the emergence of this organization. Figure IV indicates the general causal model of the emergence of Islamic State.

Figure IV

\section{Individual Motivation; Salafi-Jihadism;}

Unipolar Policies

Islamic State

Although these two models provide causal images of al-Qaeda and IS, they are not sufficient in explaining the formation of the two organizations. The causal effects as articulated in the two models were magnified by aspects of state fragility in Afghanistan and Iraq. In other words, alQaeda and IS did not directly emerge as direct outcomes of a number of independent variables at three levels of analysis as shown above. Rather, the emergence of these groups was conditioned with specific aspects of state fragility in Afghanistan and Iraq. Therefore, providing a comprehensive framework of the emergence of al-Qaeda and IS requires adding state fragility as a condition variable ${ }^{132}$ to this unilineal model. Condition variables is indicated by using the multiplication symbol " $\times$ " in a causal model. ${ }^{133}$ This symbol is used to indicate that condition variables "magnify, but not multiply, the impact of independent variables on the dependent variable." "134 This means that the impact of an independent variable(s) on the dependent variable can be magnified by a "high value on the condition variable and reduced by a low value for it."135

\footnotetext{
${ }^{132}$ Van Evera, Guide to Methods, 11.

133 Ibid., 13 ote.

134 Ibid.

135 Ibid.
} 
In my model, this would mean that a higher degree of state fragility in Muslim countries increases the probability of the emergence of SJGs while a lower degree would reduce the impact of the root cause of the emergence of these groups. Taken together, the comprehensive causal frameworks of the rise of al-Qaeda and IS can be developed into the following models, in which state fragility in Afghanistan and Iraq are added as condition variables to the initial causal framework. Figure V indicates the general model of the rise of al-Qaeda and the emergence of Islamic State is indicated in Figure VI.

Figure $\mathrm{V}$

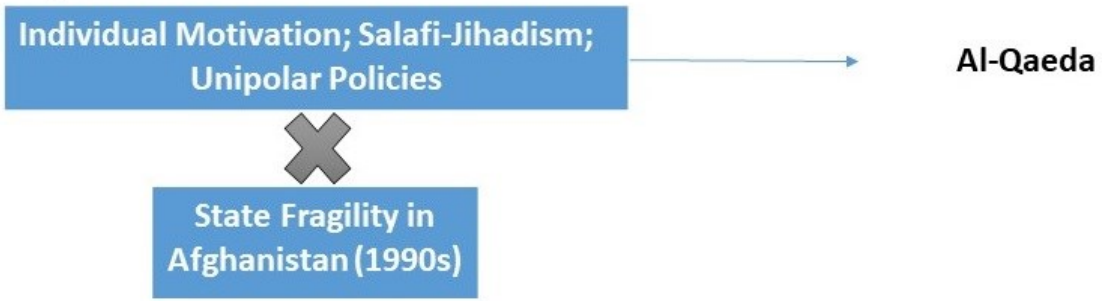

Figure VI

Individual Motivation; Salafi-Jihadism;

Unipolar Policies

Islamic State

State Fragility in

Iraq(2000s)

State fragility in Afghanistan and Iraq are measured by the three variables of legitimacy, authority, and capacity, as conceptualized in the literature. ${ }^{136}$ Concerning al-Qaeda, the finding of this dissertation shows that fragility in all three areas of legitimacy, authority, and capacity was effective in providing the conditions for the formation of this organization. In other words, poor legitimacy, poor authority, and lack of capacity in the mid-1990s Afghanistan were the conditions

${ }^{136}$ Carment et al., Security, Development, and the Fragile State, 85. 
under which individual jihadists, primarily motivated by factors at all three levels of analysis, emerged as a uniform organization. An operational model of the emergence of al-Qaeda is indicated in Figure VII.

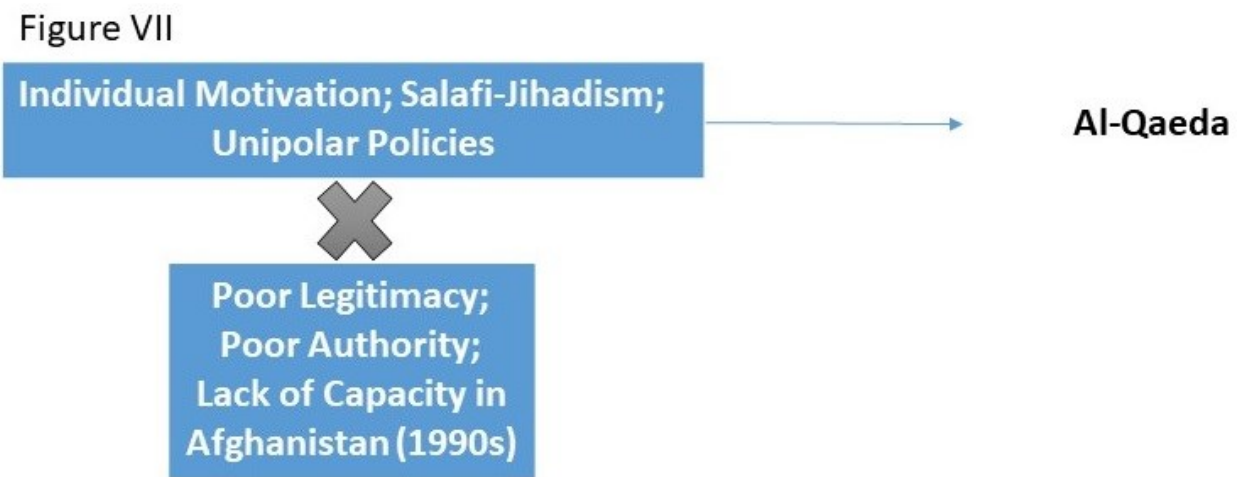

Concerning IS, two out of the three measures of state fragility, namely, poor legitimacy and lack of authority, were effective in providing the conditions for the rise of this organization, while poor capacity played a small role in the case. In other words, lack of sufficient legitimacy and authority in post-Saddam Iraq provided the conditions necessary for the emergence of IS, while poor capacity did not play a crucial role in the case. Therefore, the poor capacity factor is excluded from the model of the formation of IS. Figure VIII indicates the operational model of the rise of IS.

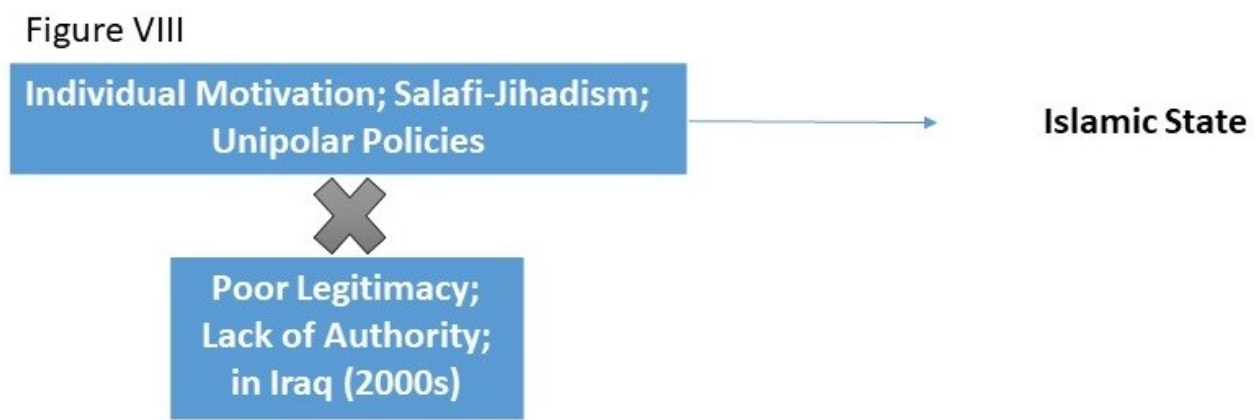




\section{Methodology}

Drawing on the method of "structured focused comparison," 137 this research is based on two similar case studies. This method allows for a careful and in-depth examination of a larger number of factors identifiable in a small number of cases rather than controlling for specific variables in a larger number of cases for generating a generalizable theory. ${ }^{138}$ This method allows for investigating a greater number of factors and complex causal mechanisms in a research project where the "puzzle of interest" lies within the selected cases, rather than in cross-case levels. ${ }^{139}$ This enables the researcher to go beyond simplistic hypothesis testing with the purpose of opening up the "black box of causality" for making a stronger within-case inference about causal processes and mechanisms. ${ }^{140}$ Informed by the strength of this method in producing an in-depth within-case conclusion, this research goes beyond unidirectional causal examinations by intensively investigating causes and conditions in two "crucial" cases. Thus, the purpose of this research is to investigate the workings of multiple aspects of a causal mechanism in which causes, conditions, and their relations and complexities are examined together for producing a within-case knowledge, rather than focussing simply on X-Y relations for a cross-case generalization. ${ }^{141}$

\footnotetext{
${ }^{137}$ George, "Case Study and Theory Development," 43-50.

${ }^{138}$ David Collier, "The comparative method," in A.W. Finifter (Ed.), Political science: The state of the discipline II 105-119 (Washington, D.C: American Political Science Association, 1993); Arend Lijphart, Comparative politics and comparative method. American Political Science Review, 65, 1971: 682-693.

139 Joachim Blatter \& Markus Haverland, Designing Case Studies: Explanatory Approaches in Small-N Research (New York: Palgrave, 2012), 79; Dirk Leuffen, "Case Selection and Selection Bias in Small-n Research," in Thomas Gschwend \& Frank Schimmelfennig (eds.), Research Design in Political Science: How to Practice What They Preach (New York: Palgrave, 2007), 148-149.

${ }^{140}$ Derek Beach \& Rasmus Brun Pedersen, Process Tracing Methods: Foundations and Guidelines, (Ann Arbor, MI: The University of Michigan Press 2013), 1-2.

${ }^{141}$ Beach \& Pedersen, Process Tracing Methods, 4-5.
} 
Three factors inform case selection. First, case selection follows a mix "crucial" and "typical" case selection method. Al-Qaeda and IS are two crucial cases in terms of producing the strongest sort of evidence for the research and they are typical because they exemplify but not represent the universe of cases. ${ }^{142}$ This method of case selection is applicable in research in which the puzzle of interest mainly lies within selected cases rather than in cross-case levels. ${ }^{143}$ The finding of a crucial case study does not necessarily generalize the problem, but provides the pretheoretical basis for generalization. ${ }^{144}$ The emergence of Al-Qaeda and IS in Afghanistan and Iraq, respectively, produces the strongest evidence on the relationship between state fragility and SJGs which, in turn, exemplifies the state fragility-terrorism nexus. Although the puzzle of interest lies within the two cases, rather than in cross-case level generalization, the conclusion produced through this research could be used in cross-case investigations which will contribute to the generation of a general theory in future. ${ }^{145}$ A large-N research, or an investigation of more cases, will indicate whether the two cases explain the relationship between state fragility and the emergence of SJGs in a general sense or not. Therefore, the selection of the two cases is relevant to the purpose of this research which is developing a hypothetical basis for further research through an intensive investigation of factors within a limited number of cases. This method might raise questions concerning the violation of "the conventional social sciences wisdom which warns to

\footnotetext{
${ }^{142}$ Harry Eckstein. "Case Studies and Theory in Political Science," in F. I. Greenstein \& N. W. Polsby (Eds.), Handbook of political science. Political science: Scope and theory 7, 1975: 118; John Gerring, "Is There a (Viable) Crucial Case Method?" Comparative Political Studies 40(3), 2007: 231-253; John Gerring \& Lee Cojocaru, "Selecting Cases for Intensive Analysis: A Diversity of Goals and Methods," Social Methods and Research 45(3), 2016: 396; Jason Seawright \& John Geering, Case selection technique in case study research: A menu of qualitative and quantitative options. Political Research Quarterly, 61(2), 2008: 297-298; 297-302.

${ }^{143}$ Gerring \& Cojocaru, "Selecting Cases for Intensive Analysis," 396; Seawright \& Geering, "Case Selection Technique in Case Study Research," 297-302.

${ }^{144}$ Seawright \& Geering, "Case Selection Technique in Case Study Research," 302.

${ }^{145}$ Seawright \& Geering, "Case Selection Technique in Case Study Research," 297.
} 
not select on the dependent variable." ${ }^{146}$ Selecting cases on the dependent variable is problematic if the researcher treats the selected case(s) as representative of a universe of cases for generalization purposes, ${ }^{147}$ which is not the case in this dissertation. As discussed, the main purpose of this research is a contribution to theory development through identifying possible antecedent conditions (aspects of state fragility), rather than theory-building. ${ }^{148}$

Second, case selection is influenced by the intrinsic importance criterion. ${ }^{149}$ Al-Qaeda and IS, as the most significant terrorist organizations of our time, matter more than other terrorist groups due to their extreme values on the condition variable (state fragility), and because of their intensive impact on similar groups and their influence in the global public debate on international security. Accordingly, the two cases provide significant instances of SJGs promising the best possible answer to the research question. ${ }^{150}$ In general, the two cases are selected on the criterion of "which one" rather than "how many" cases. ${ }^{151}$ Case selection, in this regard, is conducted purposefully, rather than randomly. ${ }^{152}$ The selection of al-Qaeda and IS, compare to other marginal cases such as AQAP in Yemen, al-Shabab in Somalia, and Boko Haram in Nigeria is informed by this intrinsic importance criterion.

\footnotetext{
${ }^{146}$ See Barbara Geddes, "How the Cases You Choose Affect the Answers You Get: Selection Bias in Comparative Politics," Political Analysis 2, 1990: 131-150; Gary King, Rober Keohane, \& Sidney Verba, Designing social inquiry: scientific inference in qualitative research (Princeton, NJ: Princeton University Press, 1994); David Collier \& James Mahoney, "Insights and pitfalls: Selection Bias in Qualitative Research," World Politics 49(1), 1996: 56-91.

${ }^{147}$ Seawright \& Geering, "Case Selection Technique in Case Study Research,” 301.

${ }^{148}$ George, "Case Study and Theory Development," 45; George and Bennett, Case Study and Theory Development, 69; Van Evera, Guide to Methods, 77-88.

${ }^{149}$ Gerring \& Cojocaru, "Selecting Cases for Intensive Analysis," 410.

${ }^{150}$ For methodology see Blatter \& Markus Haverland, Designing Case Studies, 102-103; Leuffen, "Case Selection," 152.

${ }^{151}$ B. Guy Peters, Strategies for Comparative Research in Political Science (New York: Palgrave, 2013), 38-39; Leuffen, "Case Selection," 152.

${ }^{152}$ Peters, Strategies for Comparative Research, 38-39; Leuffen, "Case Selection,” 152.
} 
Finally, and most importantly, case selection follows the "accessibility" and "pragmatism" criteria. ${ }^{153}$ Considering the limitation of time and resources for a Ph.D. program, examination of a smaller number of cases is feasible both in terms of data collection and analysis. Al-Qaeda and IS, compare to marginal instances, as mentioned, are widely reported upon and original data on state fragility in Afghanistan and Iraq are easily accessible. Data richness and accessibility of background information such as documents and sources facilitate for reaching deeper insights into causes and conditions of the two cases. ${ }^{154}$

Taken together, these case studies develop a hypothetical basis for more comprehensive research for generating a representative image of the problem. Although these case studies support my argument, I do not claim they produce a generalizable conclusion. Generating a general theory, in this regard, requires a large-N research or an intensive empirical research of a larger number of cases. ${ }^{155}$ Since in case-oriented strategies, unlike large-N research, the primary goal is "an appreciation of complexity," not generalization, ${ }^{156}$ my dissertation exemplifies the complex process of the emergence of SJGs through the two case studies and contributes to the literature by adding a new variable, state fragility, to the causal model of the problem.

This project is accomplished by a research strategy that includes literature review, content analysis, and fieldwork. First I conducted a broad literature review on both state fragility and SJGs in order to provide a background of the problem and to frame the analytical and methodological framework of my research. This dissertation, in this sense, engages with the two decade scholarly long debate on the emergence of SJGs and the state fragility-terrorism nexus literature. Next, I conducted archival research at Afghanistan Center at Kabul University, in Kabul, Afghanistan.

\footnotetext{
${ }^{153}$ Blatter \& Markus Haverland, Designing Case Studies, 102.

${ }^{154}$ Ibid.

${ }^{155}$ George, "Case Study and Theory Development," 45.

${ }^{156}$ Ragin, The Comparative Method, 54.
} 
Original data was collected from the Afghan mujahidin and the Taliban regimes' official newspapers, magazines and governmental documents archived in this center. The data were original, documented in domestic languages, Farsi and Pashto, and was used for the first time for the purpose of investigating the relationship between state fragility in the mid-1990s in Afghanistan and the rise of al-Qaeda. The reviewed documents were published between 1994 and 2001 which covered aspects state fragility in Afghanistan during the Taliban's Islamic Emirate of Afghanistan's (IEA) which came into existence in 1996 and was toppled by the US-led "operation enduring freedom" in 2001. I am fluent in both official languages of Afghanistan, Farsi and Pashtu. All original data concerning the Taliban used in this dissertation is translated into English by the author alone.

Concerning the second case study of this dissertation, the emergence of IS in post-Saddam Iraq, first, I used a large amount of primary and secondary data on state fragility in the post-Saddam Iraq and the emergence of IS. Documents and data used for this case study were mostly stored in a number of online archives including the Brookings Institute, the Washington Institute, Rand Corporation, the Center for Strategic and International Studies, the Council on Foreign Relations, and the International Center for Counter-Terrorism. Furthermore, a review of empirical findings and research on state fragility in Iraq and the rise of IS by these institutions enhanced my investigation. Finally, this case study was completed by a content analysis of a number of domestic and international newspapers. Plenty of chronological data, observations, eyewitness accounts, and interviews about state fragility in Iraq and the emergence of IS are documented in these papers.

Empirical findings support my original hypothesis. The data proves that the emergence of al-Qaeda and IS were linked to state fragility in Afghanistan and Iraq, respectively. According to this data, different aspects of state fragility in the two countries provided the conditions necessary 
for the formation and expansion of the two groups. In particular, all three aspects of state fragility in Afghanistan in the 1990s developed the conditions under which causal factors at the three levels of analysis produced al-Qaeda. Concerning IS, two state fragility measures, poor legitimacy and lack of authority, were the most effective conditions, while poor capacity played a marginal role.

\section{Organization of Chapters}

This research is organized into seven chapters. Chapter II is dedicated to a historical analysis of the state and state fragility in the Muslim world, and developing a genealogy of Salafi-jihadism and SJGs. How did sovereign states extend into the Muslim world? How are sovereign states understood, and what are their rivals in Muslim societies? Why are sovereign states in many Muslim societies highly fragile? What is Salafi-Jihadism and how did this ideology develop into contemporary jihadist doctrine? What are SJGs and how did they deviate from the broader Salafi movement? These are the major questions addressed in chapter II. The purpose of this chapter is to provide background knowledge on the state, state fragility, and SJGs.

Chapter III is dedicated to the root causes of al-Qaeda. This chapter examines the root causes of the emergence of this organization at three levels of analysis. What specific causes factored into al-Qaeda? Which factors at the individual level motivated Jihadi combatants to form al-Qaeda? How did Salafi-Jihadism at the group level of analysis factor into the establishment and expansion of al-Qaeda? How did the United States' unipolar policies in the Middle East influence the formation of al-Qaeda? Why did the causes of the formation of al-Qaeda become more effective in a specific international context, the post-Cold War international system? These questions are addressed within the levels of analysis framework in Chapter II. 
Chapter IV investigates the relationship between state fragility in Afghanistan and the rise of al-Qaeda. This chapter specifies aspects of state fragility in Afghanistan under the Taliban and examines their effects on the rise and expansion of al-Qaeda. Multiple indicators of state legitimacy, authority, and capacity in Afghanistan is discussed and explained in term of how they provided the conditions necessary for the emergence of al-Qaeda. What was the legitimacy basis of the Islamic Emirate of Afghanistan (IEA) and how did it provide the conditions necessary for the rise of al-Qaeda? How did lack of authority produce ungoverned spaces and borders that facilitated the formation of al-Qaeda? How was poor capacity in Afghanistan linked to the formation of al-Qaeda? Chapter IV deals with these questions. The purpose of this chapter is to provide a comprehensive picture of the formation of al-Qaeda in which both the independent and conditional variables of the case and their complex effects on the rise of al-Qaeda are examined in great detail.

Chapter V investigates the root causes of IS within the levels of analysis framework. Multiple factors at all three levels of analysis are organized and investigated within the levels of analysis framework in the chapter. What factors at the first level of analysis influenced individual jihadis to establish IS? How did Salafi-jihadism frame those individual campaigns toward a specific direction which ultimately resulted in the formation of IS? How did the US invasion of Afghanistan (2001) and Iraq (2003) factor into the emergence of IS at international level of analysis? Chapter V approaches these questions.

Chapter VI examines the role of state fragility in post-Saddam Iraq on the development of Iraq-based insurgency into IS. Specific aspects of legitimacy and authority in post-Saddam Iraq are discussed and explained with regard to how those factors magnified the relationship between the three-level root causes and the emergence of IS. Why did Iraq-based insurgency develop into 
a uniform transnational jihadi organization with IS lines? What role did state fragility play in the process of developing the scattered Iraq-based insurgency into a uniform organization? What was the legitimacy basis of the post-Saddam Iraq in the 2000s and how did poor legitimacy in this period contribute to the formation of IS? Why did the Coalition's state-building policy fail in restoring Iraq's defense and security sectors and how did lack of authority provide the conditions for the formation of IS? Chapter VI addresses these questions. Although poor capacity in postSaddam Iraq played a only a small role in the emergence of IS, in order to clarify the role of this factor, Chapter VI also briefly examines the relationship between poor capacity and the formation of IS.

In the concluding chapter, I provide a general image of this dissertation, outline the main findings, discuss the dissertation's contribution to both the academic and policy debate on the state fragility-terrorism nexus, and highlight the dissertation's limitations and suggest a number of recommendations for research in the future. 
II

\section{State and State Fragility in Muslim Societies; Salafi-Jihadi Groups}

This chapter provides a detailed conceptualization of the state, state fragility, and SJGs. It explains: What is a sovereign state and how did they extend and constellate in Muslim societies? Why could domestic transnational ideologies such as pan-Islamism and pan-Arab Nationalism not provide the basis for state-building and how were they marginalized by the idea of sovereignty? What are the historical and immediate causes of state-fragility in Muslim societies? What are SJGs and how are they distinguished from other types of Islamist/Salafi groups? Why did SJGs become popular, particularly in the aftermath of the Cold War?

\section{The Sovereign State and Its Extension in Muslim Societies}

The sovereign state emerged as a result of the great transformation from the medieval to the modern era from the fifteenth to nineteenth centuries. ${ }^{157}$ Most scholars see the Peace of Westphalia

157 Jackson, From Anarchy to Cosmopolis, 179; Wight, System of States, 314-21; Keen, The Penguin History of Medieval Europe; Hinsley, "The Concept of Sovereignty and the Relations Between States," 285. 
that settled the Thirty Years War (1618-48) as the best historical marker of this transformation. ${ }^{158}$ The main characteristic of this process was the gradual replacement of European pre-modern states mainly centered on the church with territorially-based governing authorities. ${ }^{159}$ As a result, all territory in Europe, and consequently all regions around the world, were portioned by sovereign states and placed under their independent authority. The twentieth century was the era of the globalization of sovereign states beyond Europe and Christian societies.

Sovereign states in the Muslim world emerged over the $20^{\text {th }}$ century from varied origins particularly nineteenth-century European colonialism and the collapse of the Ottoman Empire which led to the post-WWI settlement in the Middle East and beyond. ${ }^{160}$ As a result, dozens of sovereign states in the Muslim world emerged as "juridical entities" which mainly reflected postwar European interests rather than realities and desires in the ground. New borders in the Middle East, shaping new sovereign states, divided the Muslim Ummah into multiple territorial jurisdictions that were subsequently regarded as legitimate and lawful international entities by almost every Muslim government. ${ }^{161}$ In the immediate aftermath of WWI only one independent Arab state emerged, the Mutawakkilite Imamate of the Yemen as the immediate outcome of the defeat of the Ottoman Turks. ${ }^{162}$ By the beginning of WWII in 1939 the pattern of state formation in the Muslim world had developed to a large extent. Afghanistan achieved independence from the United Kingdom in 1919. The Kingdom of Saudi Arabia was created in the 1920s following the defeat of Sharifian rule in the Hijaz by the Al-Saud family from the Najd. ${ }^{163}$ Iraq achieved independence in 1932 and Egypt in 1936. The age of decolonization and the struggle among the

\footnotetext{
158 Jackson, From Anarchy to Cosmopolis, 82.

159 Tilly "War-Making State-Making," 179; Jackson, From Anarchy to Cosmopolis, 83; Milliken \& Krause, "State Collapse, State Failure and State Reconstruction," 755.

160 Jackson and James, State In A Changing World, 132

161 Jackson, From Anarchy to Cosmopolis, 90.

162 Jackson and James, State In A Changing World, 116

163 Ibid.
} 
newly independent nations to free themselves from foreign domination arose at the end of the WWII. ${ }^{164}$ When the United Nations was created in 1945 there were seven Muslim states amongst the founding membership, namely Egypt, Iran, Iraq, Lebanon, Saudi Arabia, Syria and Turkey. ${ }^{165}$ By 1971, another thirty Muslim States secured membership in the United Nations, including Afghanistan and Yemen Arab Republic (1946), Pakistan (1947), Indonesia (1950), Jordan and Libyan Arab Jamahiriya (1955), Morocco, Sudan and Tunisia (1956), Malaysia (1957), Guiana (1958), Burkina-Faso, Chad, Mali, Niger, Nigeria, Senegal and Somalia (1960), Mauritania and Sierra Leone (1961), Algeria and Uganda (1962), Kuwait (1963), Gambia (1965), Democratic Republic of Yemen (1967), Bahrain, Oman, Qatar and the United Arab Emirates (1971). By the beginning of the twenty-first century, the number of sovereign states in the Muslim world, according to their membership in the United Nations and the Organization of Islamic Cooperation, reached 57. 166

The new states in the Muslim world were multiethnic and usually contained significant minority communities. ${ }^{167}$ Most of these jurisdictions were either colonies of empires or internal administrative units of federal states in the past. ${ }^{168}$ Accordingly, when it came to the establishment of new sovereign states it proved impossible to draw sociologically rational borders that perfectly divided nationalities into separate territories without domestic social overlap. For instance, Iraq contained Kurdish minorities and Iran was composed of several minority groups including Kurds, Baluchs and Arabs. Therefore, the new state system in most parts of the Muslim world were challenged by two sub-state and trans-state movements: a separatist movement by the minorities

\footnotetext{
${ }^{164}$ Ibid.

${ }^{165}$ Ibid., 117.

166 "Member States of The Organization of Islamic Cooperation" (http://www.oic-oci.org/oicv2/states/); Khan, $A$ Theory of International Terrorism, 8.

${ }^{167}$ Jackson, From Anarchy to Cosmopolis, 91.

${ }^{168}$ Ibid., 92.
} 
that aimed at creating their own authorities, and transnational movements with the desire to combine the divided "Muslim nation" or ummah and the "Arab nation" under a single sovereign state in accordance with ethnic and religious lines (e.g. a pan-Arab or a pan-Islamic state).

The historical accounts of state formation in Muslim societies show that both transnational and separatist forces challenged the newly formed sovereign states, particularly between the 1940s and the 1960s. Sovereign states in the Middle East, in this period, were initially challenged by two transnational movements, Islamism, and pan-Arab Nationalism. Islamist movements emerged as a direct response to the global changes that constitute modernity and territorialization of societies. ${ }^{169}$ This movement was identified by their emphasis on a return to Islam in its purest form as the solution for the ills of Islamic societies and modern society as a whole, ${ }^{170}$ and their ideological desire for inventing an Islamic sovereign state, ${ }^{171}$ a pan-Islamic political entity ruled by the sharia. ${ }^{172}$ Likewise, pan-Arab Nationalism represented the idea that all Arabs could and must be united in a single state. Unlike European nationalism, where the focus was on maintaining and strengthening national unity within individual sovereign states, pan-Arab nationalism emphasized on the unity of all Arab societies and their incorporation into a single pan-Arab state. ${ }^{173}$

In addition to the two transnational movements, several separatist movements also challenged the newly established sovereign states. Baluchis in Pakistan and Iran, and Kurds mainly in Turkey, Iran, and Iraq are major examples of these movements. Separatists, unlike the transnational movements, did not seek to combine sovereign states but to separate from existing states and create their own governments in accordance with their ethnic lines. The common ground

\footnotetext{
${ }^{169}$ Lapidus, "Islamic Revival and Modernity,' 444-45.

170 "Islamic Modernism and Islamic Revival," Oxford Islamic Studies Online

(http://www.oxfordislamicstudies.com/article/opr/t253/e9).

${ }^{171}$ Ana Belen Soage, "Introduction to Political Islam," Religion Compass 3/5 (2009): 887.

172 Tibi, Islamism and Islam, 3-5, 16-17.

173 Rubin, "Pan-Arab Nationalism," 535.
} 
among the three movements was that they challenged the juridical boundaries of the post-WWI by insisting on the importance of sociocultural ties in international politics. Although none of those movements succeeded in their plans, the contradiction between juridical and. sociocultural realities gradually became the major sources of intra-and-interstate disputes, and thus a domestic cause of state fragility in Muslim countries. Both movements were marginalized and suppressed by emerging sovereign states that received massive foreign support as a result of international rivalries between the superpowers during the Cold War.

Thus, the development of sovereign states in Muslim countries was highly influenced by the Cold War balance of power between the two Superpowers. The newly formed states, under the circumstances of the Cold War, became the "proxy allies" of either of the two Superpowers. ${ }^{174}$ The amount of support these states received from their international sponsors were remarkable in enhancing their strength putting them in a dominant position against their sub-state and transnational rivals. Many of those states, in the end of the Cold War, collapsed due to losing the support. Therefore, the international aspect of state formation in the Muslim World can be considered as a significant explanatory variable for both state development and state fragility.

For example, a higher degree of statehood in the Soviet-sponsored states was the result of economic and military support those states received from the Soviet Union. Therefore, state fragility in those countries could be considered as an outcome of aid ending. The Soviet Union's collapse also affected the United States' foreign policy in many Muslim countries which in turn led to a high state fragility in many of those countries. A brief case study of the two superpowers' engagement in Muslim countries during the Cold War provides a clearer image of the international aspects of state development and fragility in those countries.

${ }^{174}$ Carment, “Assessing State Failure,” 407. 
Iraq, for instance, from the rise of Saddam Hussein in 1968 until the disintegration of the Soviet Union depended significantly on the Soviets, particularly in the areas of the nationalization of the Iraqi oil industry and the military. Military dependence was apparent specifically in the October 1973 Arab-Israeli War, the war in Kurdistan in March 1974, and the Iran-Iraq War (19801988). ${ }^{175}$ Iraq's dependence on the Soviet Union's military support peaked during the last years of the Iran-Iraq War with the Soviet Union's military support for the Iraqi army during the last two years of the War valuing 8.8 to 9.2 billion dollars. ${ }^{176}$ Research shows that the support included 2,000 tanks, 300 fighter aircraft, almost 300 surface-to-air missiles and thousands of pieces of heavy artillery and armored personnel vehicles. ${ }^{177}$ The amount of support Saddam Hussein's regime received from the Soviets not only allowed the Iraqi state to gain initiatives in the war but also increased the state's authority over its territory and population strengthening its military and security capabilities in the postwar years. Therefore, the collapse of the Soviet Union had a direct impact on Iraq's military and security capabilities. According to Western military experts, during the US invasion in 2003 Iraq's armed forces "were down to about 40\% of their 1991 Gulf War levels." ${ }^{178}$ Likewise, the amount of support Syria received from the USSR was remarkable. For example, from 1955 to 1960 , the Soviets provided Syria with more than $\$ 200$ million in military aid to solidify the USSR-Syria alliance and to counter US influence in the region. ${ }^{179}$ Moreover, following the defeat of Arab armies in the Arab-Israeli War of 1967, between July 1967 and

\footnotetext{
${ }^{175}$ Francis Fukuyama, "the Soviet Union and Iraq Since 1968," Rand Corporation, July 1980: 5 (https://www.rand.org/content/dam/rand/pubs/notes/2007/N1524.pdf).

${ }^{176}$ Mohiaddin Mesbahi, "The USSR and the Iran-Iraq War: From Brezhnev to Gorbachev," in The Iran-Iraq War: The Politics of Aggression, ed. Farhang Rajaee (Florida: University Press of Florida, 1993), 89.

${ }^{177}$ Mesbahi, "The USSR and the Iran-Iraq War," 89.

${ }^{178}$ Sharon Otterman, "Iraq: Iraq's Prewar Military Capabilities," Council on Foreign Relations, April 24, 2003 (http://www.cfr.org/iraq/iraq-iraqs-prewar-military-capabilities/p7695).

${ }^{179}$ Michael Sharnoff, “The Syria-Soviet Alliance," inFocus Quarterly, Spring 2009 (http://www.jewishpolicycenter.org/833/the-syria-soviet-alliance).
} 
December 1968 the Soviet Union provided Syria with $\$ 2.5$ billion in military aid. ${ }^{180}$ Thus, during the three-decade rule of Hafiz-al-Assad, the Soviet Union's aid to Syria reached billions of dollars. Likewise, in South Asia, the Soviet Union supported Afghanistan with both military and financial aid to counter the US domination of the region. From 1955-1978 the Soviet Union provided Afghanistan with $\$ 1.27$ billion in economic aid and $\$ 1.25$ billion in military aid. And according to a CIA report, in addition to the Soviet Union's massive financial aid to Afghanistan during the 1980s, arms transfers from the USSR to Afghanistan in this period was as massive as "placing the country behind only Vietnam and Cuba in terms of value received by Marxist Third World states from the Soviet Union." ${ }^{181}$ International aid enabled the Afghan state to expand its institutions throughout the country and resist the Islamist rebellion.

The Soviet Union's support to Iraq, Syria, and Afghanistan was part of a greater strategic rivalry between the two Cold War superpowers in Muslim regions. As a result, most of the Muslim states became proxy allies to one of the two Superpowers. The Kremlin, in general, supported mainly the secular nationalist and socialist governments including Egypt, Libya, Sudan, Syria, Iraq, and Afghanistan. While Iran (prior to the 1979 Islamic Revolution), Jordan, Saudi Arabia, Turkey, and Pakistan comprised the US bloc. ${ }^{182}$ The United States' billions of dollars of support to its proxy allies significantly contributed to the enhancement of statehood in those countries. ${ }^{183}$ Like the Soviet Union, the United States attempted to secure the capacity of its allies for survival through the means of arms supply, intelligence, training, and finance. As a result, by the end of the

\footnotetext{
${ }^{180}$ Sharnoff," "The Syria-Soviet Alliance,"

181 "The Cost of Soviet Involvement in Afghanistan," CIA Special Collections (2000): 2498

(http://www.foia.cia.gov/sites/default/files/document_conversions/89801/DOC_0000499320.pdf); Barnett R. Rubin, The Fragmentation of Afghanistan, Second Edition (New Haven and London: Yale University Press, 2002), 20;

"The Cost of Soviet Involvement in Afghanistan," 2498.

182 Otterman, "Iraq: Iraq's Prewar Military Capabilities."

${ }^{183}$ For example, according to a CIA report, the United States spent the equivalent of 330 billion dollars (in 1984 price) only in south Asia over the 13-year period of 1964-1976. See "The Cost of Soviet Involvement in Afghanistan," 2498.
} 
1960s, sovereign states as "proxy allies" to either of the two Superpowers achieved the capability to isolate their Islamist, Arab nationalist and separatist rivals and had the opportunity to develop a sense of state nationalism in their territories.

In addition to the major role international factors played, the development of the state and nationalism in this period had three regional reasons. ${ }^{184}$ First, following the defeat of Arab armies against Israel in the War of 1967, state-based solidarity behind the Palestine cause replaced the pan-Arab nationalist unity. ${ }^{185}$ Second, oil wealth created divergent state-based interests, empowering the desire for prioritizing relative state interests in the Middle East. And finally, divergent interests and the possibility of external threats to those interests helped develop a sense of nationhood in every Muslim state. For example, the Iranian threat created a sense of national resistance in Iraq and vice versa. ${ }^{186}$ In addition, authoritarian regimes countered the Islamist Muslim Brotherhood and the pan-Arab Baathist party by coercion. As a result, transnationalism in its two forms of Islamism and Arab Nationalism fragmented into nationalist parties that struggled for political power in specific juridical contexts. The pan-Arab Baath party, for instance, fragmented into Iraqi, Syrian, Lebanese, Jordanian, and Libyan Baathist parties and the panIslamic Muslim Brotherhood disintegrated into a number of parties that were active within sovereign state boundaries such as the Muslim Brotherhood in Syria, Iraq, Lebanon, Egypt, Tunis and the like. The emergence of new political parties further strengthened the sense of statehood and nationalism. However, the ruling parties' massive reliance on coercion and physical elimination of their rivals pushed sovereign states in the Muslim world towards authoritarianism, rather than democracy. Therefore, most of those states achieved a higher degree of authority and

\footnotetext{
${ }^{184}$ Jackson and James, States in a Changing World, 132.

185 Ibid., 133.

186 Ibid.
} 
capacity but failed in developing broad-based legitimacy. By the end of the Cold War, there was no single democratically elected regime in the Muslim world in which legitimacy was rooted in choices of their citizens.

Overall, the sovereign states in Muslim countries have developed distinct identities within new juridical boundaries separating societies that share common religious and cultural ties, on the one hand, and placing them in the broader international community of sovereign states, on the other. For example, the contemporary political development of Indonesia is as alien to Moroccans as the civil war of Somalia is for Uzbekistanis. In the Middle East, Iran, Turkey, and Egypt are all Muslim countries, but they have little else in common. This is why Khomeini's dream of creating the Islamic Republic that would be imitated by other nations and inspire oppressed people everywhere, was never realized by other nations. ${ }^{187}$ Today political differences within the Muslim world are profound and intensive, as shown by Iraq's invasion of Kuwait in 1991 which put one Muslim nation against the other. After the United States mobilized an international Coalition against Iraq, Saddam Hussein attempted to define it as a war between Islam and the West. But few believed it. Although some radical Islamist elements considered an international jihadi against the US invasion as a legitimate religious duty, most of the states in the Middle East joined a US-led Coalition against their fellow Muslim state. ${ }^{188}$ Moreover, today, the most important requirement of traveling from Egypt to Lebanon or from Afghanistan to Pakistan is the passport one holds, not the language they speak or the God they worship. During the Syrian refugee crisis, as a recent instance, the way Middle Eastern states treated the Syrian refugees was not essentially different from the treatment those refugees received in Europe - both the European and the Arab states

\footnotetext{
${ }^{187}$ Nasser Momayezi, "Islamic Revivalism and the Quest for Political Power," Journal of Conflict Studies 17/2 (Fall 1997): 115-132 (https://journals.lib.unb.ca/index.php/JCS/article/view/11753/12527).

${ }^{188}$ Momayezi, "Islamic Revivalism and the Quest for Political Power."
} 
treated them as foreigners. Lebanon and Jordan, like Germany, accepted a higher number of Syrian refugees, while the six oil-rich Gulf States of Bahrain, Kuwait, Oman, Qatar, Saudi Arabia, and the United Arab Emirates, "applied restricted visa policies and offered zero resettlement places to them." 189 These instances show that not only have sovereign states in Muslim societies well developed over the past century but also their citizens' understanding of their states and identity has been deeply transformed. Today, transnational calls, such as pan-Islamism and pan-Arab Nationalism are not serious challenges to the idea of sovereignty in Muslim countries.

\section{State Fragility in Muslim Countries}

Sovereign states in the Third World, which includes all Muslim states, began failing immediately after the end of the Cold War. The level of authority and capacity in many Muslim states that relied on the Soviet Union's military and economic support dropped shortly after the disintegration of the USSR. The end of the Cold War and the emergence of a new international system, unipolarity, also affected the United States' foreign and military policies. The US disengaged from many countries that served as its "proxy allies" during the Cold War. For instance, in order to balance the Soviet Union's influence in the Horn of Africa in the Cold War, the US provided Somalia with a remarkable amount of military and financial aid. ${ }^{190}$ The United States' interest dropped in Somalia in the early 1990s because the country had lost its strategic importance after the

\footnotetext{
${ }^{189}$ For the Gulf states' treatment of Syrian refugees see Guy Taylor, "Refugee Crisis Sparks Debate on Role of Rich Gulf Countries," The Washington Times, September 23, 2015 (http://www.washingtontimes.com/news/2015/sep/23/syrian-refugees-being-shunned-by-gulf-states).

Also see Jared Malsin, "Why Some Arab States Refuse to Accept Syrian Refugees," Time Magazine, September 15, 2015 (http://time.com/4025187/arab-states-syrian-refugees/).

And for total number of Syrian refugees and their dispersion in different Middle Eastern states see "Total Number of Syrian Refugees Exceeds Four Million For First Time,” UNHCR-The UN Refugee Agency, July 5, 2015 (http://www.unhcr.org/559d67d46.html).

190 Anthony Parson, From Cold War to Hot Peace: UN Interventions 1974-1994 (London: Penguin Books Ltd, 1995), 198-207.
} 
disintegration of the USSR which influenced in Somalia's neighbor, Ethiopia. As a result, Somalia became highly fragile and was hit by an endless civil war. Thus, state fragility became common in both US and USSR sponsored countries. Afghanistan and Somalia were the immediate cases, while other states such as Iraq, Yemen, Libya, Syria, and Egypt followed a gradual process of increasing fragility. However, some Muslim countries such as Saudi Arabia, and United Arab Emirates, and Tukey in which US foreign policy remained intact did not experience severe fragility. According to the FFP Fragile States Index, of the 57 Muslim majority countries only a few, including the three aforementioned ones, are ranked as relatively stable, while the rest are listed as the world's highly fragile states. ${ }^{191}$ According to this index, two Muslim states, Qatar, and the United Arab Emirates were ranked as stable states in 2014. Two more cases, Oman, and Kuwait were ranked less stable. Eleven states were ranked "warning" and "high warning", including Bahrain, Malaysia, Saudi Arabia, Turkey, Maldives, Jordan, Indonesia, Tunisia, Azerbaijan, Turkmenistan, and Algeria. The rest are considered as very highly fragile states. Ten out of the top twenty most fragile states of the world are Muslim majority states which include Somalia, Sudan, Chad, Afghanistan, Yemen, Pakistan, Iraq, Syria, Niger, and Nigeria. ${ }^{192}$ Empirical findings show that all of these eleven states have experienced the emergence and development of SJGs: al-Shabaab in Somalia; the Taliban and al-Qaeda in Afghanistan and Pakistan; al-Qaeda in Sudan; AQAP in Yemen; IS in Iraq and Syria; and Boko Haram in Nigeria, Niger, and Chad. This general assessment can explain a clear relationship between state fragility and the emergence of SJGs in the Muslim world providing an empirical support for the central argument of this research.

Part of state fragility in those countries could be explained by historical factors such as juridical and sociological contradictions, sectarian and ethnic diversities, and the resistance of

\footnotetext{
${ }^{191}$ Haken et al., The Fragile States Index 2014, 2-5.

192 Ibid.
} 
suppressed peoples against authoritarian regimes, however, the severe occurrence of fragility and failure after the end of the Cold War marks the determinant role of the international system shift in this case ${ }^{193}$ Most of the analyses that merely consider historical factors as the main causes of state fragility in the Muslim world are limited to domestic factors and exclude the foreign policy aspects of the problem. Such analyses are mainly inspired by historical accounts which consider state formation in the Third World essentially as a failed experience. ${ }^{194}$ Those accounts, simply, connect contemporary state fragility to the colonial origins of state-building in the Third World. ${ }^{195}$ According to those accounts, one can conclude that sovereign states in the Muslim world emerged originally weak and failed and never became capable of fulfilling the fundamental task of the regular European sovereign states. They provide a simplistic conclusion: Third World states are bound to remain fragile because they were formed fragile in the first place.

These studies rarely consider the evolution of state institutions and the development of different national identities in Muslim countries as discussed in the previous section. Empirical evidence on the development of sovereign states in Muslim societies indicates that the degree of fragility in all three measures of legitimacy, authority and capacity, in addition to historical variables, depends on systemic variables such as the form of the international system, and the nature of states' relations to a great power. Historical experiences show that domestic causes under

\footnotetext{
${ }^{193}$ Carment, Assessing State Failure, 407-408; Michael Ignatieff, Blood and Belonging (Toronto: Viking Press, 1993), 8 .

${ }^{194}$ Collier, "The Political Economy of State Failure," Andrew Taylor, State Failure (London: Palgrave Macmillan, 2013), 118-140; Rosa E. Brooks, "Failed States, or State as Failure," The University of Chicago Law Review 72/4 (2005): 1167-1168; Bruce J. Berman, "Ethnicity, Patronage and the African State: The Politics of Uncivil Nationalism," African Affairs 97/388 (Jul., 1998): 305-341; Crawford Young, The African Colonial State in Comparative Perspective (New Haven and London: Yale University Press, 1994); Jean Francois Bayart, The State in Africa: the Politics of the Belly (London: Longman, 1993); Juan Vincent, "Sovereignty, Legitimacy and Power: Prolegomena to the Study of the Colonial State in Early Modern Uganda," in State Formation and Political Legitimacy, ed. Ronald Cohen and Judith D. Toland (New Brunswick: Transaction Books, 1988), 137-154.

${ }^{195}$ Collier, "The Political Economy of State Failure;" Taylor, State Failure, 118-140; Brooks, "Failed States, or State as Failure,"1167-1168; Berman, "Ethnicity, Patronage and the African State," 305-341; Young, The African Colonial State in Comparative Perspective; Bayart, The State in Africa; Vincent, "Sovereignty, Legitimacy and Power."
} 
different international conditions have factored into different results toward statehood and state fragility. For example, domestic factors in Iraq and Syria during the 1970s and 1980s, and in Turkey and Saudi Arabia today under specific international circumstances, contributed to the development of higher degrees of statehood. Whereas, in cases such as Afghanistan in the 1990s statehood dropped for systemic reasons, and then intensified as a result of historical factors such as ethnolinguistic and political rivalries. Therefore, developing a comprehensive account of state fragility in Muslim countries requires both historical and systemic factors to be considered and examined as interconnected causes of statehood and state fragility.

\section{Salafi-Jihadi Groups: Background}

Islamism, also known as Salafism, uses a certain version of Islam as the foundation of an ideology which considers the formation of an Islamic state as a religious duty and an ultimate goal. Islamism, in this sense, is an ideology which is basically about the formation of a political entity. Scholars have distinguished Islam from Islamism based on different criteria. However, most agree that the main difference between the two can be defined as the difference between faith and ideology. ${ }^{196}$ As Tibi (2012) put it, "Islamism is about political order, not faith. Nonetheless, Islamism is not mere politics but religionized politics." ${ }^{197}$ Accordingly, "Islamism bears a dual nature of religion and politics in pursuit of a divine order," a sharia-based Islamic state. ${ }^{198}$ Islamists believe that the establishment of the Islamic state is a return of history and glory. Therefore, their practical solution to the contemporary problems of Muslim societies is the remaking of a caliphate

\footnotetext{
196 Tibi, Islamism and Islam, 1.

${ }^{197}$ Ibid, 1.

${ }^{198}$ Ibid., 243.
} 
which is to be "the nucleus of an Islamic world order." 199 Islamism, in this sense, is both about domestic and international politics.

The Islamists' call for a return to Islamic history and glory is a call for a return to the Islamic civilization that developed between the seventh and seventeenth centuries when Muslims engaged in war mainly with non-Muslims for dominance in world politics. ${ }^{200}$ Though successful in medieval times, the Islamic caliphate never becames the dominant order in the world, with Muslim lands being periodically attacked and invaded by other competing powers. ${ }^{201}$ The first remarkable defeat of Muslims was in the late thirteenth and early fourteenth century by Mongols. The Muslim civilization was finally defeated by Europe as a result of the industrial revolution in the seventeenth century which put Europe in a dominant technological position. The last Muslim caliphate, the Ottoman Empire, entirely disintegrated into new sovereign states after WWI, shaping a new geopolitical order in the Middle East. This is the history to which Islamists refer. They believe that restoring the glorious civilization in the absence of a sharia-based state is not likely. Thus, the return of glory, according to the Islamist ideology, requires an anti-Western, antiSemite - and in its contemporary version anti-American ${ }^{202}$ — front to lead a global jihad with the goal of establishing the Islamic State. Islamism, in this sense, is a reactive ideology that aims to revenge the historical defeats of the Muslim empires.

It is clear that all forms of Islamist movements draw on Islamism as their source of inspiration and motivation. However, the origins of this ideology, and when and how it emerged and developed, is debatable. At least three historical accounts of Islamism which trace this

\footnotetext{
199 Ibid., 53.

200 Ibid., 45-50.

201 Ibid., 50.

202 The perception is borrowed from Tibi (2012) who describes Islamism as an anti-Western, anti-Semite and antiAmerican phenomenon. Tibi, Islamism and Islam, 50.
} 
ideology's origins in three different times are worth noting. ${ }^{203}$ The three accounts share one common ground linking the origins of Islamism to the works of scholars in different periods or to the emergence of an Islamist movement against a foreign invasion.

First, a number of scholars search for the origins of Islamism in the works of a Muslim jurist, Ibn Taymiyyah (1263-1328) who initially called upon Muslims to defend the Muslim lands against the Mongol invaders by relying on the methods of jihad that Muslims used at the dawn of Islam. ${ }^{204}$ Taymiyyah's emphasis on a return to the fundamentals of Islam as the solution to the ills of Islamic societies was later interpreted by scholars as "Islamic fundamentalism." Second, scholars who consider the emergence of Islamism as a reaction to the cultural and political defeats of the Ottoman Empire in the second half of the eighteenth century. ${ }^{205}$ This account connects the emergence of Islamism to the works of Sayyid Jamal al-din al-Afghani (1838-1897), a Muslim political thinker and Islamic revivalist who worked for a pan-Islamic unity. ${ }^{206}$ Afghani lived in a time in which the Islamic Empire was defeated from the West and Muslims experienced humiliation in the face of Western advances in science, culture, and technology. Afghani propagated the idea that the reason for the decline of Islamic civilization was the result of Muslims' deviation from the path of true Islam, rather than their weakness. ${ }^{207}$ Therefore, Afghani emphasized that if a spiritual revival could be achieved then the Islamic world which once was superior to the

\footnotetext{
${ }^{203}$ Ali Bulac, “On Islamism: Its Roots, Development, and Future," Insight Turkey 14/4 (2012): 67-85; Corbin, AlQaeda, 11; Christina Hellmich, "Creating the Ideology of al-Qaeda: from Hypocrites to Salafi-Jihadists," Studies in Conflict \& Terrorism 31 (2008): 114-15; Palmer, and Palmer, Islamic Extremism, 12-13; Richard. H. Dekmejian, Islam in Revolution: Fundamentalism in the Arab World, Second Edition (New York: Syracuse University Press, 1995).

${ }^{204}$ Palmer and Palmer, Islamic Extremism, 12-13; Corbin, Al-Qaeda, 11; Christina Hellmich, "Creating the Ideology of al-Qaeda: from Hypocrites to Salafi-Jihadists," Studies in Conflict \& Terrorism 31 (2008): 114-15.

${ }^{205}$ Ali Bulac, “On Islamism: Its Roots, Development, and Future," Insight Turkey 14/4 (2012): 67-85; Richard. H. Dekmejian, Islam in Revolution: Fundamentalism in the Arab World, Second Edition (New York: Syracuse University Press, 1995).

${ }^{206}$ John Turner, "From Cottage Industry to International Organisation: The Evolution of Salafi-Jihadism and the Emergence of the Al Qaeda Ideology," Terrorism and Political Violence 22(4), 2010: 541-558.

${ }^{207}$ Christopher Henzel, "The Origins of the Al Qaeda Ideology: Implications for US Strategy," Parameters (Spring, 2005): 72.
} 
West could reemerge stronger in world politics as it had done centuries before. ${ }^{208}$ Third, there are scholars who synchronize the emergence of Islamism with the establishment of the Muslim Brotherhood in the 1920s as a reaction to the post-WWI European political and cultural hegemony in the Middle East. ${ }^{209}$ These scholars connect the emergence of Islamism, mainly, to the works of Afghani's student, Muhammad Rashid Rida (1865-1935) and the like-minded Sayyid Qutb who called upon Muslims to wage an armed struggle "against every obstacle that comes into the way of worshiping God and the implementation of the divine authority on earth."210

The two latter accounts, although providing comprehensive analyses on aspects of the Islamist ideology and movements, confuses the emergence of Islamism as an ideology with the emergence of Islamism as a political movement. Moreover, the two accounts do not consider the chronological development of Islamism and the continuous impact of the works of Islamist thinkers such as Ibn Taymiyyah and Muhammad ibn Abd-al-Wahhab (1703-1792), the founder of Wahhabism, on Islamist ideology. Hence, I draw on the first account considering Taymiyyah as the founder of the Islamist ideology and the Muslim Brotherhood as the first Islamist/Salafi movement in the modern era. The analysis of contemporary Islamist movements indicates that they all, although to varying degrees, connect themselves to the tradition of Taymiyyah and the political objectives of the early Muslim Brotherhood and its founders.

Thus, Islamism as an ideology emerged in the early fourteenth century, with Taymiyyah as its founder and caller. Taymiyya observed a strict methodological approach to interpreting Islam and considered the Quran and Hadith as the only true sources of knowledge. His approach to Islamic scholarship and statecraft sought to draw guidance from the past and look at Islam in its

\footnotetext{
${ }^{208}$ Henzel, "The Origins of the Al Qaeda Ideology," 72.

209 Tibi, Islamism and Islam.

210 Gerges, The Rise and Fall of al-Qaeda, 4-5; Razwy, A Restatement of the History of Islam, 132.
} 
more basic and elemental form. ${ }^{211} \mathrm{He}$ positioned the importance of jihad as equal to the five pillars of Islam and argued for the restoration of the caliphate in a new historical setting. ${ }^{212}$ Taymiyya refused to accept the subordination of religion to politics; for him they were essentially linked. ${ }^{213}$ What follows from Taymiyyah is an evolutionary intellectual process over the next seven centuries to the present day through a number of thinkers who contributed to shaping what has become the contemporary Islamist doctrine. Although from Taymiyyah to bin-Laden to Zawahiri to Baghdadi, there has been a progression in Islamist thought resulting in different versions of the ideology in different periods, Islamism's foundation remains the same: a return to Islam in its purest form for inventing a Sharia-based political order in the Muslim world.

Following the invention of Islamism by Taymiyyah, Muhammad ibn Abd-al-Wahhab (1703-1792) revived the ideology introducing it as the formal doctrine of a state, Saudi Arabia. Islamism as a political movement first appeared in the second half of the nineteenth century ${ }^{214}$ as a reaction to invading modern cultures and values' and to the defeats of the Ottoman Empire. ${ }^{215}$ However, Islamism as an organized movement emerged in 1924 in the form of the Muslim Brotherhood in response to the European invasion and re-territorialization of the Ottoman Empire. The early Islamist waves were not organized, being more religious reactions to modernity than political. Therefore, I highlight the Muslim Brotherhood as the first organized and objective Islamist movement with a clear political agenda. A brief review of the evolution of Islamism from the late $19^{\text {th }}$ century to the formation of the Muslim Brotherhood helps to have a clearer image of the development of this organization.

\footnotetext{
${ }^{211}$ Dan Benjamin, The Age of Sacred Terror: Radical Islam (Maryland: Random House, 2003), 52.

${ }^{212}$ Benjamin, The Age of Sacred Terror, 47, 49.

${ }^{213}$ Benjamin, The Age of Sacred Terror, 48.

${ }^{214}$ Bulac, "On Islamism," 68.

${ }^{215}$ Ibid., 69.
} 
The $19^{\text {th }}$-century Islamist waves were mainly motivated by Afghani who, like Taymiyyah, sought to reform Muslim societies by looking back to the time of the Prophet for guidance. He also tried to internalize some selective Western concepts in Muslim societies and Islamic literature to bridge the gap between secular modernists and traditionalists. ${ }^{216}$ Thus, Afghani's doctrine included two patterns, a pure Islamist one which searched for solutions in the past and a modern one which aimed to tolerate parts of contemporary realities. Afghani's doctrine was taken into two different directions by two of his students, Muhammad Abduh (1849-1905) and Muhammad Rashid Rida (1865-1935) in the early twentieth century. ${ }^{217}$ Abduh followed the direction which emphasized the incorporation of Western rationalism in Islamism. ${ }^{218}$ This stream broadly contributed to the formation of pan-Arab Nationalism in the mid-twentieth century. ${ }^{219}$ Rida followed the direction of pure Islamism which rejected the Western modernity entirely. Rida believed that "only an Islamic world completely absent from Western influences could escape the colonial noose." ${ }^{220}$ The foundations of pan-Islamism, the Muslim Brothers' Salafism, and finally Salafi-Jihadism were set by the stream initially developed by Rida.

The collapse of the Ottoman Caliphate in 1924 and the establishment of sovereign states including the Republic of Turkey on the Ottoman territories was a turning point in the history of Islamism. The Muslim Brotherhood emerged in 1928 as a reaction to the disintegration of the Ottoman territories and the colonization of Muslim societies by the conquerors of the WWI. The key figure behind the establishment of the Muslim Brotherhood was Hassan al-Banna (19061949), an enthusiastic follower of Rida who was intensively driven by a sense of "cultural

\footnotetext{
${ }^{216}$ Turner "From Cottage Industry to International Organisation," 548; Sayed A. A. Razwy, A Restatement of the History of Islam and Muslims (Stanmore: The World Federation of Muslim K.S.I. Communities, 1997), 117.

${ }^{217}$ Razwy, A Restatement of the History of Islam, 132.

${ }^{218}$ Henzel, "The Origins of the Al Qaeda Ideology," 72-73.

219 Turner, "From Cottage Industry to International Organisation," 549.

${ }^{220}$ Benjamin, The Age of Sacred Terror, 56.
} 
catastrophe." ${ }^{221}$ He entirely rejected the concept of the nation-state and therefore new sovereign realities such as modern Turkey and Egypt. ${ }^{222}$ The objective of the Muslim Brotherhood was to restore God's sovereignty and promote a government that would operate "on the basis of Muslim values and norms." 223

Sayyid Qutb (1906-1966), a follower of Banna and a member of the Egyptian Muslim Brotherhood, can be considered as the most influential contemporary Islamist ideologue and an essential contributor to the emergence of SJGs. Qutb, following his brief period of living in the United States, took a sharp turn towards Islamism. He observed America and the West as "decadent, sinful, and corrupt."224 The famous Islamic studies scholar, John Esposito (2002), believes that Qutb transformed Banna's "simplistic and vague methodological approach to establishing an Islamic state into a revolutionary call to arms." ${ }^{225}$ Moreover, drawing on Abul-Ala Mawdudi’s (1903-1979) methodology who declared Islam as “a revolutionary ideology," 226 Qutb was able to extract the key concepts of Islamism such as jihad, dar-al-harb (the house of war) and dar-al-Islam (the house of Islam) out of their spiritual context into core elements of a political ideology."227 Qutb defined the relationship between dar-al-harb and dar-al-Islam by comparing

\footnotetext{
${ }^{221}$ Ibid., 71.

${ }^{222}$ Barry Cooper, New Political Religions or an Analysis of Modern Terrorism (Columbia: University of Missouri Press, 2004), 105.

${ }^{223}$ Lawrence Davidson, Islamic Fundamentalism: An Introduction (Connecticut: Greenwood Press, 2003), 98.

${ }^{224}$ Sayyid Qutb, "The America I have Seen: In the Scale of Human Values," in America in an Arab Mirror: Images of America in Arabic Travel Literature, ed. Kamal Abdel-Malak (New York: St. Martin's Press, 2000), 9-28; Turner, "From Cottage Industry to International Organisation," 550.

${ }^{225}$ Esposito, Unholy War, 56.

${ }^{226}$ Benjamin, The Age of Sacred Terror, 60. Mawdudi was the founder of Islamism in the Indian Subcontinent and the founder of Jamaat i Islami. He provided the link for the transition between Banna's vague methodological approach to establishing an Islamic state and the revolutionary ideology of Qutb. Maududi observed that Muslims had essentially overthrown God's sovereignty and began to impose secular legal who provided the link for the transition between Banna's vague methodological approach to establishing an Islamic state and the revolutionary ideology of Qutb. See Trevor Stanley, "Maulana Maududi: Radical Islam's Missing Link," Perspectives on World History and Current Events (www.pwhce.org/maududi.html).

${ }^{227}$ Turner, "From Cottage Industry to International Organisation," 549.
} 
the relationship between the United States and Egypt. ${ }^{228}$ In his comparison, he not only attacked the former's economic, military and political power but also its culture. ${ }^{229}$ Contemporary SJGs and jihadi ideologues purely draw on Qutbian doctrine and, therefore, disconnect from post-Qutbian narratives which directed Islamist ideology toward near-enemy-centrism and supported nonviolent political campaigns from the late 1960s to the end of the Cold War.

Overall, Islamism is an ideology which incorporates works and thoughts of a series of Islamist scholars and activists who follow a tradition of thought invented as early as in the early fourteenth century by Taymiyyah. All Islamist groups and thinkers, including Salafi-Jihadis of our time, inherit this tradition and use it, although with a variety of interpretations as their guidance. The Islamist emphasis on a return to the fundamentals of Islam is not a call for a return to a past era or civilization. Rather, it represents an effort to cope with contemporary problems by a renewed commitment to an early version of sharia. ${ }^{230}$ The purpose of using this method is to justify the establishment of a modern state by drawing on early messages, rather than modeling the Prophetic political order in a new era. Islamists, in this sense, use the early ideals of their faith, selectively, to justify the establishment of a modern political order, rather than relying on the faith to establish a "heavenly rule on earth." Therefore, the kind of state Islamists expect to form is more similar to a Platonic Callipolis ruled by "the best of best," or Salafi Ulima, rather than the Augustinian Kingdom of Heaven. How to get to this goal is the question that every version of the Islamist movement approaches differently. This results in the emergence of a variety of Islamist streams that are different in four key elements of the ideology which include the definition of a global problem, characterization of an enemy that causes the problem, definition of a method of action to

\footnotetext{
${ }^{228}$ Ibid., 550.

229 Ibid.

${ }^{230}$ Lapidus, "Islamic Revival and Modernity," 444.
} 
solve the problem, and more importantly the definition of an ultimate goal. This differentiation is explained by a terminological, historical and typological analyses of the Islamist movements in the following sections.

\section{Terminology of SJGs}

Terminological ambiguity in Islamism and terrorism literature is a major source of confusion in understanding the origins, characteristics, and development of Islamist groups. The 11 September 2001 events and its subsequent counterterrorism campaign led to the emergence of a massive literature on terrorism and Islamism. Part of this literature, regardless of its poor empirical and theoretical basis, because of the topicality of the issue was published in prestigious publications. In most of the literature, terms such as Islamism, Salafism, jihadism, terrorism, extremism, fundamentalism, radicalism, and the like are used interchangeably in order to explain a single phenomenon. Thus groups such as al-Qaeda and its offshoots are labeled simultaneously as terrorist, Islamist, extremist, jihadi, and radical groups. These terms represent different realities, some being broader than others and some very particular. Terms such as Salafism, Islamism, extremism, radicalism, and fundamentalism are very broad and applicable to almost all spectrums of Islamist groups, whereas, terms such as jihadism, and Salafi-jihadism refers to a particular strand of those groups and, therefore, is applicable to specific groups such as al-Qaeda and IS. Groups such as al-Qaeda and the Egyptian Muslim Brotherhood can be equally described as fundamentalist or Islamist groups, while, the Muslim Brotherhood is not a jihadi or Salafi-jihadi organization. Therefore, while these groups share the same ideological basis, they differ in their organizational and opertional characteristics and their political goals. 
Moreover, some terms such as terrorism, radicalism, and extremism are basically political, therefore, it is easy to label a group as terrorist or radical for political purposes. For example, a broad range of groups, due to their opposition to specific regimes or political movements, are categorized as terrorist groups in the literature which confuses terrorism as the enemy of a state with terrorism as a jihadi organization with international political purposes. During the Cold War, for instance, many national liberation movements such as the Palestinian operations against Israel which received moral and material assistance from the Soviet Union were branded as terrorists by Israel and the United States. Likewise, groups such as the Afghan mujahidin and many other jihadi groups which obtained arms from the United States and its allies against the Soviet occupation of Afghanistan were labeled by the Soviet Union and its allies as terrorists and fundamentalists. Accordingly, the term terrorism in this period served as a political weapon to selectively condemn specified threats, but not others. ${ }^{231}$ While the Palestinians were terrorists for Israel and the US, they were freedom fighters for many others including the Soviet Union. Likewise, the Afghan mujahedeen were freedom fighters for the US and terrorists for the USSR. ${ }^{232}$

Considering this terminological ambiguity, I use the term Islamism (interchangeably with Salafism) as an inclusive and broad concept which all strands of Islamist movements from politicos to Jihadis share as a common ideology. However, I use a particular term in order to identify the case studies of this research within the universe of Islamist groups, Salafi-Jihadi Groups (SJG). I consider SJGs as a particular strand of Salafi/Islamist movement which share a common ideology with other Islamist groups and differ from them by their specific characterization of the four key elements of the Islamist ideology.

\footnotetext{
${ }^{231}$ Khan, A Theory of International Terrorism, 4.

${ }^{232}$ Ibid.
} 


\section{Development of SJGs}

Islamism as an ideology, as discussed, developed from Taymiyyah's teachings in the early fourteenth century. But Islamism as a political movement did not exist before the second half of the nineteenth century. ${ }^{233}$ It is not surprising, because until the mid-19 ${ }^{\text {th }}$ century Islam was considered as the founding ideology and the framework of legitimacy of the Ottoman Empire. ${ }^{234}$ In the face of such a governing authority it was difficult for an Islamist movement to lay legitimate roots in Muslim society. However, the Ottoman Empire's defeats by Europe pushed the Ottoman elites to follow a new path, parallel to Westernization. The groundwork for Islamism, as an answer to invading cultures and values, was prepared in this historic and societal context. ${ }^{235}$ Since then there have been three generations of Islamists. The first generation was active from the second half of the nineteenth century until 1924 when Kemal Ataturk dissolved the Ottoman Caliphate in favor of the creation of a Turkish nation-state. The first generation was mostly inspired by Afghani. The second generation played a role from the 1960s to the end of the Cold War and was mainly influenced by the Muslim Brotherhood. And the third generation of Islamists stepped onto the scene in the aftermath the Cold War. The third generation is mainly associated with al-Qaeda and its offshoots. Since the first generation of Islamists was not organized and more a religious reaction to Westernization than a political one, this research considers the emergence of the Islamist movement as an organized and political movement by the rise of the second generation and, particularly, with the formation of the Muslim Brotherhood in 1928. This generation, initially propagating pan-Islamism, subsequently turned into national parties, prioritizing politics over ideology. ${ }^{236}$ Therefore, the parties inspired by the Muslim Brotherhood did not practically turn into

\footnotetext{
${ }^{233}$ Bulac, "On Islamism," 68.

234 Ibid., 69.

235 Ibid.

${ }^{236}$ Choueiri, Islamic Fundamentalism, 226-29
} 
a pan-Islamic threat to the international order. ${ }^{237}$ The Egyptian Muslim Brotherhood's political purpose, for instance, since the 1960s has been to build an Islamic state within the Egyptian state. ${ }^{238}$ These parties are what I refer to as Political Islamist Groups (PIGs) which were the dominant strand of Islamism until the end of the Cold War. With the end of the Cold War, a new strand of Islamist groups deviated from the main body of the movement which reinterpreted the key elements of the ideology. These are the groups I refer to as SJGs which include al-Qaeda.

Historically, Salafi-Jihadism, as a militant Islamist discourse and movement, first emerged in the 1970s. The movement was divided into two main streams, a majority school which mainly followed a near-enemy-centrist strategy, and a minority branch which was far-enemy-centrist. From the 1970s until the end of the Cold War, the far-enemy-centrists were marginalized when near-enemy-centrism was the most attractive and popular narrative of jihadism in Islamist communities. ${ }^{239}$ The two streams, while using Islamism as a common ideology, differed in interpreting the core elements of this ideology. The near-enemy-centrists, for instance, defined secular rule over the Muslim societies as the problem, and "apostatic regimes" in Muslim countries as the enemy. ${ }^{240}$ They also defined a "domestic and defensive" jihad as the method of fighting the enemy and considered the replacement of secular regimes with sharia-based Islamic states as the goal. ${ }^{241}$ With the transformation of the international system at the end of the Cold War, however, near-enemy-centrism's popularity was replaced with a new strand of Salafi-jihadi groups that claimed to provide a new response to the problems of Muslim societies and international political issues in general. Thus, the new strand which suddenly became attractive in Salafi communities

\footnotetext{
${ }^{237}$ Esposito, The Islamic Treat, 222-26.

${ }^{238}$ Dekmejian, Islam in Revolution, 76.

${ }^{239}$ Gerges, The Far Enemy, 43-55.

${ }^{240}$ Ibid.

${ }^{241}$ Choueiri, Islamic Fundamentalism, 223-236; Gerges, The Far Enemy, 43-55;
} 
redefined all core elements of the ideology. ${ }^{242}$ The far-enemy-centrists characterized "the American domination of the Muslim lands" as the problem; the United States and its allies as the enemy; a global jihad as the method; and the formation of an Islamic state, as the nucleus ${ }^{243}$ of a new global order as the ultimate goal. The four key elements of this ideology are clearly expressed in al-Qaeda's declarations and its leadership's statements and interviews. ${ }^{244}$

The emergence and sudden popularity of far-enemy-centrism was the outcome of the experiences of a generation of Salafi-Jihadis who were inspired primarily by "the rhetoric of an absolutist and textualist ideology (Qutbian doctrine)," radicalized by the Afghan war in the 1980s, and motivated for a global jihad due to personal experiences and the observation of the Muslim communities" "bitter experiences" in early 1990s. ${ }^{245}$ By SJGs, I particularly refer to this strand of Salafi-jihadi movement.

However, despite the recent popularity of far-enemy-centrism and its strict strategic distinction from near-enemy-centrism, the two strands are interconnected and enjoy a similar ideological basis. Therefore, contemporary SJGs, although prioritizing far-enemy-centrism as the core strategy, encompass elements of both strands of Salafi-jihadism. For instance, while organizations such as al-Qaeda are purely far-enemy-centrist, groups such as IS encompass both far-and-near enemy centrism. Despite different prioritization of the enemy, violent method and the ultimate goal is what unites all SJGs. Although the ultimate goal of organizations such as al-Qaeda is the establishment of an Islamic state ruled by Sharia they also support campaigns against false

\footnotetext{
${ }^{242}$ Choueiri, Islamic Fundamentalism, 223-236.

243 On this see Tibi, Islamism and Islam, 53.

${ }^{244}$ See Al-Adnani, ISIS Spokesman Declares Caliphate; Al-Zawahiri, His Own Words; Al-Zawahiri, "Knights Under the Prophet's Banner;" Bin Laden, "Declaration of War Against the Americans Occupying the Lands of the Two Holy Places;" Bin Laden, et al, "World Islamic Front Statement."

${ }^{245}$ Gerges, The Rise and Fall of Al-Qaeda, 67; Murden, Islam, the Middle East and the New Global Hegemony, 197; Ibrahimi, "Theory of the Rise of al-Qaeda."
} 
Muslim rulers (e.g. in Afghanistan, Saudi Arabia, Egypt, Uzbekistan, etc.). ${ }^{246}$ Nevertheless, these organizations prioritize far-enemy-centrism following the global agenda of creating an Islamic state. Statements from Bin Laden, Zawahiri, Zarqawi, Sayf al Adl, and other al-Qaeda leaders display the "uncompromising commitment" of Salafi-Jihadist leaders to the ideological agenda of the creation of an Islamic state. ${ }^{247}$ Overall, this dissertation divides Salafi-Jihadi movement into two strands including PIGs and SJGs. A better understanding of this distinction requires developing a typology of Islamist groups in which the branching of the two streams is explained. This typology shows that how SJGs deviated from the main Salafi movement and which organizations today can be considered SJGs.

\section{Typology: PIGs vs. SJGs}

Scholars have developed three typologies of Islamist groups. First, a number of scholars have made a general distinction between moderate and radical Islamist groups. ${ }^{248}$ According to this categorization, moderate Islamists are made up of moderate reformers (the majority) which seek to return to the basics or fundamental truths of the religion as a means of resolving contemporary political, social, economic and other problems. Its members advocate the use of democratic and electoral means to bring about a non-violent transfer of power within the nation. ${ }^{249}$ Moderates see no contradiction between Islam and Western philosophies and institutions. ${ }^{250}$ By contrast, the radical Islamists (the minority), consider violence central to the political cleansing necessary to

\footnotetext{
${ }^{246}$ Rohan Gunaratna. Inside al-Qaeda: Global Network of Terror (New York, NY: Colombia University Press, 2002), 55.

${ }^{247}$ Christopher M. Blanchard. Al-Qaeda: Statements and Evolving Ideology. CRS report for Congress. 2007, p. 15. Retrieved from https://fas.org/sgp/crs/terror/RL32759.pdf

${ }^{248}$ John L. Esposito, "Terrorism and the Rise of Political Islam,"143-158; Esposito, The Islamic Threat;"

Momayezi, "Islamic Revivalism;" Richard Augustus Norton, ed. Civil Society in the Middle East, vols. 1 and 2 (Leiden: E.J. Brill Publishers, 1994 and 1995).

${ }^{249}$ Momayezi, "Islamic Revivalism."

${ }^{250}$ Ibid.
} 
establish a new social order. Its members engage in violence to bring about a quick transfer of power. ${ }^{251}$ This minority believes that it has a "divine mandate to topple the rulers of its country and impose its own interpretation of sharia on the society." ${ }^{252}$ This distinction considers all moderate groups as nationalist parties with national structures and agendas whose ultimate goal is the transformation of power in national contexts. This categorization does not recognize the ideological similarities between the two categories which are not national and prescribes the establishment of a transnational Islamic state and transformation of global power as the ultimate goal and solution. Moreover, distinguishing radical Islamists from the moderate ones only by means of operation (violence vs. moderation) puts a wide range of groups that follow different goals in a single category. In this typology, groups such as al-Qaeda and militant nationalist groups in Palestine and Chechnya are categorized as same groups which are problematic.

Second, and similar to the first, a number of researchers divide Islamist groups on the basis of their means of action into violent Islamists from non-violent Islamists. ${ }^{253}$ This typology, although elaborating the first categorization, does not provide a broad and persuading image of the problem. First, the typology is limited to the cases only from Saudi Arabia excluding Islamist groups and organizations that emerged and developed in other societies. Moreover, and similar to the first categorization, it excludes ideology as a defining element of Islamist groups. Therefore, it includes a number of reformist and sectarian groups in the typology which are not necessarily ideological Islamists. ${ }^{254}$

\footnotetext{
${ }^{251}$ Ibid.

${ }^{252}$ Ibid.

${ }^{253}$ For example Thomas Heggharmmer, Jihad in Saudi Arabia: Violence and Pan-Islamism since 1979 (Cambridge: Cambridge Uinversity Press, 2010), 6.

${ }^{254}$ See M. Zuhdi Jasser et al, Muslim Reform Movement, Gatestone Institute, December 6, 2015

(http://www.gatestoneinstitute.org/7009/muslim-reform-movement).
} 
Finally, a third typology is developed by the Syrian-German political scientist, Bassam Tibi (2012) who distinguishes between institutional and jihadist groups on a means vs. goal based criterion. According to this categorization, the institutional/peaceful and jihadist/violent branches of Islamist groups differ over the means by which the Islamist world revolution is to be brought about but they are similar in terms of the goal. ${ }^{255}$ Tibi believes that all Islamist groups follow the same Islamist ideology of the invention of a sharia-based state, but their approach to how to reach the goal differs. ${ }^{256}$ Although Tibi's argument about similarities of Islamists in terms of ideology and goal and their differences in terms of means adds new insights to the debates, his generalization about similarities of all Islamist groups in terms of the goal is problematic. Evidence shows that institutional Islamists, or what I call PIGs, do not follow a transnational agenda which is a contribution to the establishing a pan-Islamic Islamic state, but a national one which is to win the political game within the boundaries of existing sovereign states. For example, while parties such as AKP and the Egyptian Muslim Brotherhood and the like might speak in rhetoric about their international dream of restoring the Islamic caliphate, they practically function as national parties. The AKP leadership, for instance, states in political rhetoric that "we want al-Andalus [Islamic Spain] back and we are going to take revenge for the defeat in Vienna 1683 "257 Or "we shall restore the Ottoman Balkans." ${ }^{258}$ In practice, the AKP considers itself as a political party that follows the Constitution of the Republic of Turkey. ${ }^{259}$

Considering different aspects of the existing typologies, I add further required details and insight to categorize the Islamist groups into PIGs and SJGs. Although I initially rely on Tibi's

\footnotetext{
255 Tibi, Islamism and Islam, 24, 50.

256 Tibi, Islamism and Islam, 10-11, 51.

${ }^{257}$ Ibid., 101, 50.

258 Ibid., 101.

259 "By-Law of the Justice and Development Party: With Amendments Effected in 2012," Chap 1. Article. 2 \& Chap 2, AK Parti (https://www.akparti.org.tr/english/akparti/parti-tuzugu).
} 
means vs. goal-based categorization, I operationalize the term of goal into short-term goals and an ultimate goal. Most PIGs, in this sense, can be identified on the basis of their prioritization of a short-term political goal which is the establishment of Islamic states within sovereign state boundaries. By contrast SJGs are characterized by their ultimate ideological goal, the establishment of a transnational Islamic state as the nucleus ${ }^{260}$ of an international order. Moreover, concerning the means, I distinguish between the groups that use violence as the only means and groups that rely on violence as one of the many possible options. PIGs, in this sense, use mostly non-violent approaches as their primary means but might rely on violence when other options are not possible, whereas SJGs rely on violence as the only and primary means of operation. These considerations helps to provide a more detailed and clearer typology of Islamist groups. This typology, in general, distinguish SJGs from PIGs on the basis of five criteria: organizational characteristics, political agenda, means of operation, prioritization of goal, and the definition of jihad.

First, unlike PIGs that are institutionally centralized organizations and function mainly as national parties, SJGs operate as transnational organizations acquiring membership from multiple nations. Examples of the former are AKP, Annahda, and the Egyptian Muslim Brotherhood, and examples of the latter include al-Qaeda and IS. However, each category borrows organizational elements of the other when necessary. Second, PIGs prioritize a near-enemy-centrist political agenda, whereas SJGs follow a mixed far-and-near-enemy centrism, while prioritizing far-enemycentrism in most of cases. SJGs that entirely focus on far-enemy-centrism include al-Qaeda and groups that use a mixed far-and-near-enemy centrism include a range of organizations like Islamic State, the Taliban, and al-Shabab. Although a SJG such as IS has been attempting to occupy lands

260 Tibi, Islamism and Islam, 53. 
that belong to different nation-states in the Middle East, its political agenda is not a national transition of power. Rather, IS incorporates near-and-far-enemy-centrism to achieve the international goal of inventing a caliphate. Moreover, groups such as the Taliban focus on toppling a national government, they enjoy transnational structure and interact with many SJGs that follow transnational agendas. Third, PIGs use democratic methods and peaceful means of transition of power when possible as short-term political tools, whereas SJGs rely on violence and military approaches as the only means of operation. The fourth criterion that distinguishes PIGs from SJGs is a distinction between political and ideological goals. While PIGs prioritize their political goal, SJGs do not distinguish between their political or short-term, and ideological or long-term, goals. The SJGs' goal is initially to eliminate the West's influence from the Islamic World and ultimately to extend a new Islamic state. The last, but not least, element that distinguishes the two categories of Islamist groups is their different interpretation of jihad as a method of struggle. The definition of jihad for PIGs is jihad as a defensive policy against foreign occupation and globalization and as a tool for preserving the community. Whereas, jihad for SJGs is equated with jihadism, an offensive ideology. ${ }^{261}$ In this sense, jihad becomes "equated with an ideology that uses violence as its hallmark and a method of struggle for achieving the eventual goal of Muslims' domination over the entire globe." ${ }^{262}$ The traditional definition of jihad is jihad as a defensive/reactive strategy against foreign occupation. The classical view held that jihad was a collective duty that could be activated only if outside enemies threatened or invaded Muslim lands. ${ }^{263}$ The definition of jihad as a defensive strategy is primarily rooted in the Quran's chapter on Jihad and Hijra that is "fight and flight." This chapter presents the Quran's prescriptions for fighting against persecution. ${ }^{264}$ Jihad

\footnotetext{
${ }^{261}$ Choueiri, Islamic Fundamentalism, 224; Tibi, Islamism and Islam, 6.

262 Choueiri, Islamic Fundamentalism, 224-25.

${ }^{263}$ Gerges, The Far Enemy, 10; Khan, A Theory of International Terrorism, 7.

${ }^{264}$ Khan, A Theory of International Terrorism, 7.
} 
and Hijra, in this sense, are reactive, rather than proactive strategies. ${ }^{265}$ Although jihad was also used as a method of classical wars for expanding the Islamdom and Islamic civilization between the seventh and seventeenth centuries, Muslim scholars have constantly emphasized on unarmed and defensive jihad. ${ }^{266}$ Jihadism's origin can be traced to the work of Sayyid Qutb who attacked Muslim scholars with "defeatist and apologetic mentalities for confining jihad to a defensive war." ${ }^{267}$ Qutbian jihadism, in this sense, consisted of both local and global aspects, toppling secular governments in the Muslim world through military coups and confronting the non-Muslim world with all means possible. While Islamists during the Cold War drew exclusively on Qutb's local aspects of jihad, the post-Cold War jihadis relied on Qutb's offensive and global aspect of jihadism. This global conception of jihadism was primarily developed by bin-Laden and Zawahiri in the mid-1990s who initially called on Muslims "to hit the main [far] enemy... the ZionistCrusader alliance." ${ }^{268}$ Accordingly, bin-Laden transformed the conception of jihad from localism to globalism and from defensive to offensive. Bin-Laden's paradigmatic shift from conventional jihadism gave birth to a new type of globalist Islamist movement that initially appeared in the form of al-Qaeda and expanded through its offshoots such as Islamic State. The following diagram provides a general image of SJGs and its branching and historical development from the main body of Salafi ideology and movement.

\footnotetext{
${ }^{265}$ Ibid.

${ }^{266}$ Jadul-Haq Ali, Jadul-Haq, ed., Bayan li al-nas, [Declaration to Humanity], vol. 1 (Cairo: al-Azhar, 1988), 273291. The source is referenced in Tibi, Islamism and Islam, 23.

${ }^{267}$ Gerges, The Far Enemy, 4.

${ }^{268}$ bin Laden, "Declaration of War Against the Americans Occupying the Land of the Two Holy Places."
} 


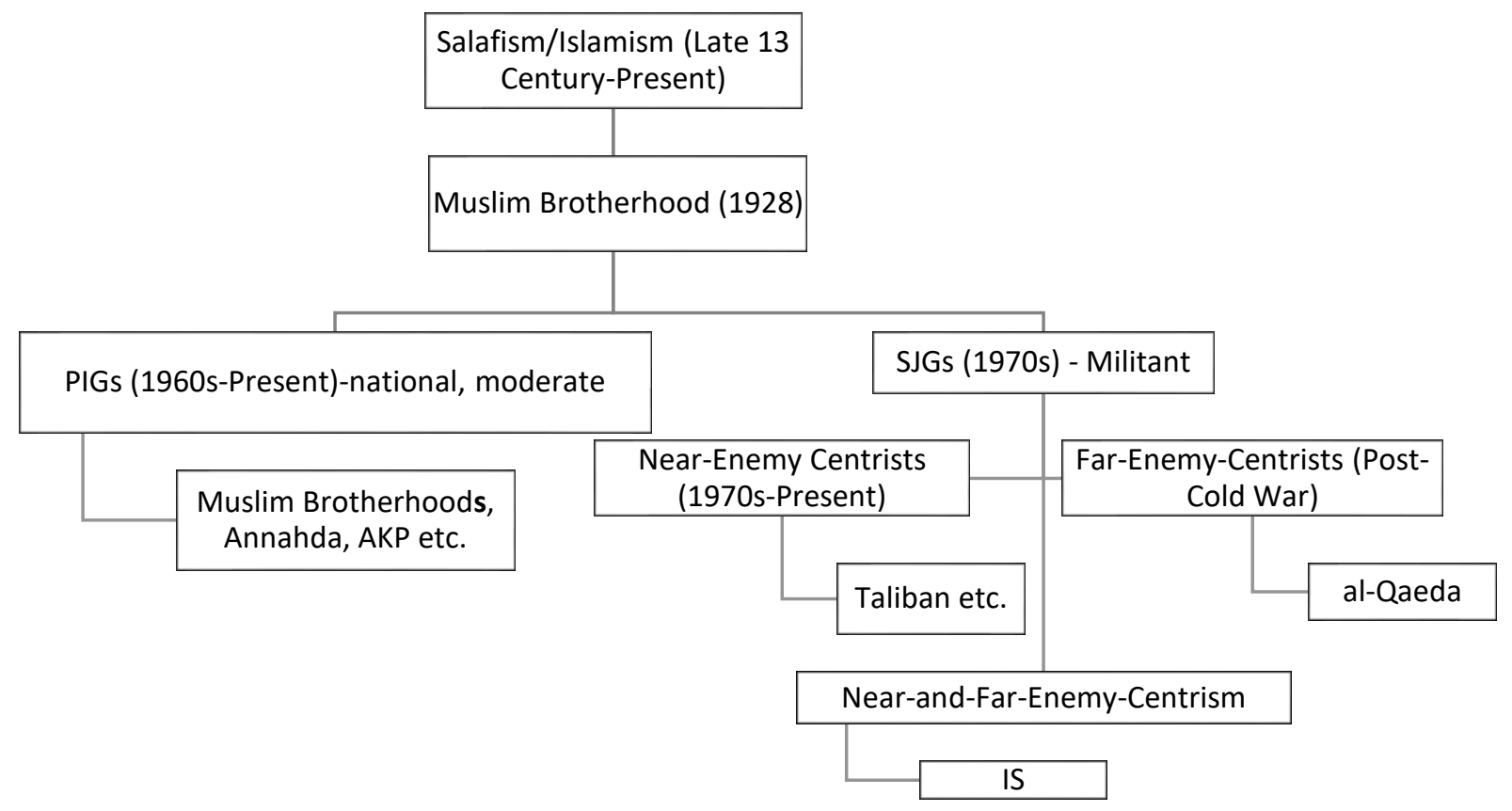




\section{III}

\section{Root Causes of al-Qaeda}

\section{Background}

Al-Qaeda as a "coordinating base" was formed around 1988 by Osama bin Laden in Peshawar, Pakistan. The starting point of the formation of al-Qaeda was the establishment of Maktab alKhidamat $(\mathrm{MaK})$ or the Services Bureau by bin Laden and his Jordanian/Palestinian mentor Abdullah Azzam in 1984. MaK was founded to coordinate incoming "Islamic aid" for funding the anti-Soviet Afghan war and equip Arab jihadis to the frontlines in Afghanistan. ${ }^{269}$ With the 1979 Soviet invasion of Afghanistan, Islamists from all over Muslim countries moved to Pakistan to join the Afghan mujahidin for liberating Afghanistan from the Soviet occupation. During the Afghan war, Pakistan and southern areas of Afghanistan became a meeting place for Islamists from all Muslim countries. The Afghan war, in this sense, was the first step in bringing the Islamists of different origins together in one place. ${ }^{270}$ The war brought together from 10 to 50 thousand volunteer jihadis from every Muslim country. ${ }^{271}$ Many came from the Arab countries, giving rise to the term 'Afghan Arabs.' 272 The Afghan mujahidin did most of the fighting, however, it was the Afghan Arabs who transformed the rebellion into a religious fight, a jihad. ${ }^{273}$ Bin Laden

\footnotetext{
${ }^{269}$ Palmer, and Palmer, Islamic Extremism, 13.

${ }^{270}$ Ibid., 130.

${ }^{271}$ Gerges, The Rise and Fall of al-Qaeda, 34.

272 Palmer, and Palmer, Islamic Extremism, 16.

273 Ibid., 13.
} 
was one of an estimated 10 thousand young Saudis who went to Afghanistan to volunteer for the battle. $^{274}$

The rush of men and material into Afghanistan created the need for a central base to process recruits and coordinate incoming "Islamic aid" resulting in the establishment of MaK led by Abdullah Azzam. Azzam was a leading figure of the Muslim Brotherhood and also a professor at the International Islamic University in Islamabad, Pakistan, in the 1980s. His second in command was Osama bin Laden, then a young man in his twenties. ${ }^{275}$ Bin Laden's relation to Azzam goes back to the time when he studied economics and management at King Abdulaziz University in his hometown, Jeddah, Saudi Arabia. Azzam was then a professor of economics at that university who also gave speeches on Islam and politics, most of which the young bin Laden attended in as an excited audience. ${ }^{276}$ Bin Laden also possessed a strong practical background in business and construction and had contacts with the Saudi royal family and wealthy Saudi Sheikhs. ${ }^{277}$

Once MaK was founded in 1984, the 22-year-old bin Laden became its "chief fund-raiser." The organization was initially created to provide accommodation and logistical services to transport the flood of volunteers to the front lines and provide for their needs. ${ }^{278}$ At the height of the Arab influx into Peshawar, between 1984 and 1986, the MaK channeled several billion dollars' worth of Western financial and material resources into the war. The organization worked closely with the ISI, the Pakistani intelligence service, and with the Saudi government. ${ }^{279}$

By 1986, bin Laden was playing a more active role in military actions. He set up his first military camp in the mountainous areas of Jaji district of the southern province of Paktia,

\footnotetext{
${ }^{274}$ Corbin, Al-Qaeda, 16.

${ }^{275}$ Gunaratna, Inside al-Qaeda, 18-22.

${ }^{276}$ Corbin, Al-Qaeda, 11.

277 Palmer and Palmer, Islamic Extremism, 131.

${ }^{278}$ Corbin, Al-Qaeda, 16.

279 Ibid., 17.
} 
Afghanistan, in $1986 .{ }^{280}$ The most significant battle he was involved occurred in 1987 in Jaji in which a small group of his fighters stopped a Soviet advance. ${ }^{281}$ The victory gave bin Laden more confidence in conducting independent operations. On the other hand, his relationship with Azzam became strained mainly due to their different perspective about MaK's relationships with the Afghan jihadi leaders, not because of any ideological disagreements. Azzam preferred supporting Ahmad Shah Masoud while bin Laden emphasized close relations with Gulbuddin Hekmatyar, leaders of two different Afghan jihadi groups. ${ }^{282}$ During this time, Bin Laden came also under the influence of a man who would ultimately replace Azzam as his religious and political mentor, Ayman al-Zawahiri. ${ }^{283}$

Zawahiri, an Egyptian doctor, met bin Laden in Peshawar when he treated him for his high blood pressure. The doctor was the leader of the Egyptian militant Islamist group called Islamic Jihad, which was responsible for the assassination of President Anwar al-Sadat of Egypt. Settled in Peshawar during the 1980s, Zawahiri was using his medical skills to treat Afghan refugees and his political skills to "expand his creed of violence" against the Egyptian state. He recognized Afghanistan as "a fertile ground" for developing the ideology of jihadi resistance. ${ }^{284}$ The intellectual role of Zawahiri in the emergence of the ideology of contemporary global jihadi organizations is more significant than Azzam and bin Laden. Azam was a talented rhetorical leader and bin Laden was a charismatic organizer while Zawahiri was a person of ideas. Azzam transformed a mixed group of jihadists working with national movements into a unified international force during the Soviet-Afghan War. ${ }^{285}$ It was, however, Zawahiri who crafted the

\footnotetext{
${ }^{280}$ Ibid., 18.

${ }^{281}$ Ibid., 19.

282 Ibid.

${ }^{283}$ Ibid., 20.

${ }^{284}$ Ibid.

${ }^{285}$ Andrea McGregor, “Al Qaeda's Egyptian Prophet: Sayyid Qutb and the War on Jahiliya," Terrorism Monitor $1 / 3$, October 10, 2003
} 
ideology for this force. ${ }^{286} \mathrm{He}$ is the author of "Knights under the Prophet's Banner" (2001) which in fact is the al-Qaeda Manifesto, outlining in great detail the organization's objectives, strategies, and ideology. ${ }^{287}$

In 1988, bin Laden split from Azzam and MaK completely and established a separate guesthouse in Peshawar called al-Qaeda al-Askarya (AQA) or the military base. AQA's primary purpose was supporting the jihad against the Soviets, coordinating funds and volunteer jihadis, recording the names of the Afghan Arabs and informing the families of those who were killed during the war in Afghanistan. ${ }^{288}$ AQA opposed Azzam's perspective of "al-Qaeda al-Sulbah, the Solid base," and was different from the contemporary al-Qaeda, both in terms of organizational and ideological characteristics. ${ }^{289}$ Organizationally, AQA did not have a formal organizational structure with a core strategy-making group at its head. ${ }^{290}$ Rather, it was a simple coordinating 'base' that was formed by mainly informal relationships around Bin Laden. Ideologically, AQA, unlike al-Qaeda, was not a caliphate-based and anti-Western organization, and Bin Laden did not express strong anti-Western views until the 1990-1991 Gulf War. ${ }^{291}$

The Afghan Arabs were not formal members of AQA and AQA did not have any organizational or ideological authority over them. They were volunteers who were free to leave the Afghan war upon their personal decision. AQA's main operation was to facilitate the jihadis' material needs and coordinate them to the frontlines. For this reason, most of the Afghan Arabs,

\footnotetext{
(http://www.jamestown.org/programs/tm/single/?tx ttnews $\% 5 \mathrm{Btt}$ news $\% 5 \mathrm{D}=18980 \& \mathrm{tx}$ ttnews $\% 5 \mathrm{BbackPid} \% 5 \mathrm{D}=$ $178 \&$ no cache $=1 \#$. VrzKn IrLDc).

286 Turner, "From Cottage Industry to International Organisation," 551.

${ }^{287}$ Ibid., 552.

288 A. Jalata, Phases of Terrorism in Age of Globalization: From Christopher Columbus to Osama Bin Laden (New York, NY: Palgrave Macmillan, 2016), 78.

289 Jalata, Phases of Terrorism in Age of Globalization, 198; L. Wright, First Edition. The Looming Tower: AlQaeda and the Road to 9/11 (New York, NY:Vintage Books, 2006), 153.

${ }^{290}$ See Palmer and Palmer, Islamic Extremism, 148; Katherine Zimmerman, The al-Qaeda Network: A new Framework for Defining the Enemy (Location: American Enterprise Institute, 2013), 1.

291 (Gerges, The Rise and Fall of al-Qaeda, 48-59; Palmer and Palmer, Islamic Extremism, 148.
} 
including bin Laden, following the Soviet's withdrawal from Afghanistan in 1989 returned to their country of origin with the hope of strengthening local Islamist organizations or creating their own. ${ }^{292}$ Some of them returned to normal life while a number stayed in Afghanistan and Pakistan either to continue supporting the Afghan mujahidin against the Soviet-sponsored Kabul government or to simply hide from being prosecuted in their home countries. ${ }^{293}$ Therefore, AQA, unlike al-Qaeda, was neither a global jihadi network nor a hierarchical organization.

Regardless of the organizational and ideological difference between AQA and al-Qaeda, much scholarly account that traces the origins of al-Qaeda in the 1980s does not differentiate between the two. ${ }^{294}$ After the withdrawal of the Soviets from Afghanistan, AQA practically disintegrated and Bin Laden, like many other Afghan Arabs, returned to his home country in 1989, where he was welcomed as a hero by the Saudi royal family. ${ }^{295} \mathrm{He}$ continued to wage an "antiMarxist crusade," targeting the socialist government of South Yemen. ${ }^{296}$ "He did not express strong anti-Western views and there was no change in his ideas until the early 1990s." ${ }^{297}$ According to Genrges (2011) the author of the "rise and fall of al-Qaeda," the catalyst of transformation in bin Laden's view was “the American military intervention in the Gulf and its preliminary stationing of troops in Saudi Arabia (1990-91), Islam's birthplace and bin Laden's home.”298 Following the Gulf war, Bin Laden and his followers viewed the American action as part of "American post-Cold War scheme" to invade the region. ${ }^{299}$

\footnotetext{
292 Palmer, and Palmer, Islamic Extremism, 132.

${ }^{293}$ Anne Stenersen, "Al-Qaeda versus Najibullah: Revisiting the Role of Foreign Fighter in the Battle of Jalalabad and Khost, 1989-92," in War and State-Building in Afghanistan: Historical and Modern Perspective, ed. Scott Gates and Kaushik Roy (London and New York: Bloomsbury, 2015), 131-34.

${ }^{294}$ For example, Gunaratna, Inside al-Qaeda; and Mamdany, Good Muslim Bad Muslim.

295 Palmer and Palmer Islamic Extremism, 132.

${ }^{296}$ Corbin, Al-Qaeda, 30.

${ }^{297}$ Gerges, The Rise and Fall of Al-Qaeda, 49.

${ }^{298}$ Gerges, The Rise and Fall of Al-Qaeda, 48; and Palmer and Palmer, Islamic Extremism, 132.

${ }^{299}$ Gerges The Far Enemy, 146; and Gerges, The Rise and Fall of Al-Qaeda, 49.
} 
At the beginning of the Gulf War, bin Laden requested the Saudi royal family "rely on God and organize a mujahidin group against the regime of Saddam Hussein, instead of relying on Americans," 300 offering the royal family the services of his jihadi veterans. ${ }^{301}$ The Saudi government disregarded his proposal which consequently damaged his relationship with the Saudi royal family. He continued his rhetoric against the US intervention in the Middle East but he still did not translate his antipathy to the US and Saudi into concrete action. ${ }^{302}$ After the Saudi authorities seized his passport in 1991 in an attempt to keep him under control, bin Laden left the country. He first traveled to Pakistan and likely to Afghanistan (March 1992) to coordinate thousands of wandering jihadis. All over the Middle East restless Afghan Arabs had tried to settle back at home. But, being considered dangerous and thus unwelcomed by their governments, they were hiding everywhere possible in the Middle East and South Asia. Bin Laden primarily attempted to find a way to bring them all together in Sudan, a new safe haven offered by the Sudanese Islamist government to bin Laden to stay.

In the Sudan, the National Islamic Front had seized power through a military coup in 1989. The real power behind the new government was an Islamist scholar, Dr. Hassan al-Turabi who dreamed of establishing a pure Islamic government across the Muslim world seeing bin Laden as an influential and wealthy figure whom he could use in his campaign. ${ }^{303}$ Al-Turabi offered bin Laden a refuge in Sudan where he finally entered with many of his Afghan Arabs at the end of 1990. ${ }^{304}$ Sudan was an important station and a convenient springboard for bin Laden's journey toward establishing al-Qaeda. In Sudan, he had the time to develop the idea of creating al-Qaeda

\footnotetext{
${ }^{300}$ Gerges, The Rise and Fall of Al-Qaeda, 48; Palmer and Palmer, Islamic Extremism, 132.

${ }^{301}$ Corbin, Al-Qaeda, 27.

302 Gerges, The Rise and Fall of Al-Qaeda, 49.

${ }^{303}$ Corbin, Al-Qaeda, 30.

304 Ibid., 31.
} 
as an offensive and global jihadi organization but he did not establish the organization practically in Sudan.

Bin Laden spent millions of dollars in road construction and other development projects during his four-year stay in Sudan. ${ }^{305}$ Using these projects as an umbrella, bin Laden built his complex network of transnational jihad through employing hard-core Islamist ideologues, some of the Afghan Arabs, and other exiled Islamist militants as project managers and coordinators. ${ }^{306}$ In addition to bringing the Afghan Arabs together, he was successful in unifying jihadi groups of different Muslim regions including The Libyan Fighting Group, the Moro Liberation Front in Malaysia, Abu Sayyaf in the Philippines, and the Group Islamique Arme of Algeria by his philosophy of jihad..$^{307}$

Despite the high political and operational capabilities bin Laden had, he lacked the religious credibility required for leading an Islamist movement. He was not a respected Islamic scholar and needed religious authority to give cover to his developing philosophy of global jihad. Therefore, during 1992 and 1993 he developed a religious committee consisted of members with more religious training to codify and justify his philosophy through fatwas, or religious rulings. ${ }^{308}$ Once it was done, bin-Laden began establishing military training camps on the Afghan model in Sudan, inviting other jihad groups to send their soldiers to these camps for training. This was the beginning of putting ideas in practice for establishing a global Islamic front.

A name for bin-Laden's ideal organization was another issue to be resolved during the time of his stay in Sudan. According to Jamal al-Fadl, a Sudanese al-Qaeda defector who give evidence in a New York court against members of al-Qaeda, some in bin-Laden's inner circle wanted the

\footnotetext{
${ }^{305}$ Gerges, The Rise and Fall of Al-Qaeda, 51.

${ }^{306}$ Corbin, Al-Qaeda, 33-34; and Gerges, The Rise and Fall of Al-Qaeda, 51.

${ }^{307}$ Corbin, Al-Qaeda, 54.

${ }^{308}$ Ibid., 37.
} 
organization to be named "the Islamic Army" but in the end Fadl stated "we went with alQaeda."309 Al-Qaeda primarily referred to both training camps and operations by individuals connected to bin-Laden. Nevertheless, a uniform hierarchical organization with a unified strategy to be named al-Qaeda was not yet formed.

During bin-Laden's stay in Sudan, militant Islamists attributed to his network involvement in several operations including the Black Hawk Down in Somalia, the New York bombing on 26 February 1993, the Riyadh Bombing on 13 November 1995 and the bombing of a US military base in the city of Dhahran in Saudi Arabia, in June 1996. Although these operations were attributed to bin-Laden and his jihadi network, al-Qaeda, at this stage, was not established as a concrete hierarchical operational organization. It was neither formed as a uniform organization nor had it formally announced an anti-American global strategy. According to Nasir Ahmad Nasir Abdullah al-Bahri, bin Laden's personal guard, a number of those bombings attributed to al-Qaeda had more to do with domestic politics in Saudi Arabia than with international affairs or American foreign policy. ${ }^{310}$ Evidence shows that bin Laden's network, in this stage, had infiltrated many countries and established informal alliances with other similar-minded jihadist cells and factions. ${ }^{311}$ However, this neither meant the existence of a hierarchical operational organization with a global ideology nor the activation of al-Qaeda as a formal organization at this stage. Rather, the plans and ideas to create such an organization were put into place during bin Laden's four-year stop in Sudan. ${ }^{312}$ The years in Sudan had enriched bin Laden's ideological education and rhetorical skills. $^{313}$

\footnotetext{
${ }^{309}$ Ibid., 38.

${ }^{310}$ Gerges, The Far Enemy, 55.

311 Ibid., 53.

312 Ibid., 51.

313 Ibid., 57.
} 
The series of bombings attributed to bin Laden, as listed above, put Sudan under enormous pressure from the Americans and the Saudis to get rid of him. By now, Dr. al-Turabi had concluded that his guest and friend was becoming "too hot" even for him to handle. As a result, before operationalizing his imagined organization for a global jihad, bin Laden had to leave Sudan. Thus, bin Laden was in need of another place to develop and operationalize his idea of creating al-Qaeda which was eventually provided by Afghanistan in 1996. Afghanistan now was a collapsed state, ruled by the Taliban who had modeled the country on a medieval theocracy. The leader of the Taliban, Mullah Mohammed Omer, was entitled Amir ul-Momineen, the Commander of the Faithful, who believed in having the right to lead all Muslims, not only the Afghans. Afghanistan, in this sense, was not only a safe haven for bin Laden and his network but also led mainly by an Islamist who like Dr. al-Turabi shared the idea of a unified Muslim world under a single leadership with bin Laden.

Once he arrived in Afghanistan in May 1996, bin Laden built on the skills he had developed in Sudan, embarking on a systematic building of training camps to operationalize al-Qaeda and turn it into a unified global jihadi organization. ${ }^{314}$ Shortly after his arrival in Afghanistan, bin Laden released his first official fatwa which announced the beginning of a global battle against the Americans. The fatwa, entitled 'Declaration of War against the Americans Occupying the Land of the Two Holy Places,' first appeared in the London-based paper, al-Quds al-Arabi, on 23 August 1996 calling upon all Muslims to liberate the Two Holy Mosques. Although the fatwa announced a war and called upon Muslims to join the jihad, however, it did not concretely announce the establishment of a specific organization or front which was supposed to organize or lead the war. The fatwa, in general, explains the situation of the Muslim world, priorities of a jihad against the

\footnotetext{
${ }^{314}$ Gerges, The Rise and Fall of Al-Qaeda, 57.
} 
US and its allies, calls upon the Muslim youth to join the jihad and asks the Muslim people to unify behind and support the mujahidin "in every possible way." 315

It seems that bin Laden and his inner circle, at this stage, had not come to a conclusion about details and aspects of al-Qaeda as a concrete organization. The completion of the project of al-Qaeda and the activation of the organization took two more years. In order to materialize his idea of al-Qaeda, bin Laden from 1996 to 1998 invested considerable time and energy recruiting young jihadis - veterans of combat in Bosnia, Chechnya, Algeria, Egypt, Iraq and elsewhere training them with ideology and operational skills.

Afghanistan as a collapsed state neither could control its borders to stop the infiltration of jihadis from all over the Muslim countries nor did the Taliban, as a jihadi group, have the intention to do so. Dozens of training camps were set up mainly in southern and eastern areas of Afghanistan to train the young jihadi fighters from all around the Muslim world. Every camp provided trainees with specific specialties. Al-Qaeda trainees in Al-Farouq camp near Kandahar, for instance, mostly received small-arms and explosives training, map-reading, and orientation. While Derunta, near Jalalabad, provided bomb-making training. Moreover, some camps were exclusively used to train specific nationalities. For example, Khalden near Khost, al-Badr I and II, al-Katbah I, and Moroccan camps in Derunta and Tunisian camps in Jalalabad were exclusively used to train European and North American jihadis. ${ }^{316}$ Despite the various trainings each camp provided, every al-Qaeda trainee was required to receive a couple of months training in al-Farouq before entering other particular camps. ${ }^{317}$ In addition to building camps and recruiting thousands of more men, bin

\footnotetext{
${ }^{315}$ Osama bin Laden, "Declaration of War Against the Americans Occupying the Land of the Two Holy Places," Bin Laden's Fatwa, PBS NEWSHOUR, August 23, 1996, accessed February 10, 2016, http://www.pbs.org/newshour/updates/military-july-dec96-fatwa_1996/

${ }_{316}$ Gunaratna, Inside al-Qaeda, 98.

${ }^{317}$ Ibid.
} 
Laden was also busy with bringing together a coalition of some of the world's jihadi groups during these two years. ${ }^{318}$

By 1998, bin Laden had built a central hierarchy that unified and managed the training camps, coalitions, and operational units in Afghanistan. He formed a network of extremist individuals and jihadi groups around a central organizational structure which consisted of seven administrative branches that coordinated the organization's functions in the areas of strategymaking, religion, politics, military and finance. ${ }^{319}$ The organization bin Laden developed between 1996 and 1998 in Afghanistan was fundamentally different from MaK and AQA which were active during the 1980s. Although following the 9/11 attacks al-Qaeda increasingly became decentralized, conducting its operations and attacks through decentralized networks such as local Islamist militant groups and "informal human relationships," the core group continued to direct alQaeda in a centralized sense. ${ }^{320}$ Al-Qaeda, in this sense, remains as an organization consisting of a hierarchical structure that leads and directs the organization and an informal complex human network which mainly conducts field operations in both individual and group levels. ${ }^{321}$ Between 1996 and 1998 in Afghanistan, bin Laden spent countless hours with his recruits defining the problems of the Muslim world (the US occupation of Muslim lands), the 'new enemy' that causes the problem (Judeo-Crusader alliance led by the US), the method to resolve the problem (a global jihad), and the goal, the formation of an Islamic caliphate. ${ }^{322}$ These elements characterizing alQaeda as a far-enemy-centrist Salafi-Jiahdi organization are clearly indicated in bin Laden's

\footnotetext{
${ }^{318}$ Corbin, Al-Qaeda, 66.

319 "Overview of the Enemy," National Commission on Terrorist Attacks Upon the United States, Staff Statement No. 15, June 16, 2004: 2 (http://govinfo.library.unt.edu/911/staff_statements/staff_statement_15.pdf).

${ }^{320}$ Zimmerman, "The Al-Qaeda Network," 1.

${ }^{321}$ Ibid., 7-9.

${ }^{322}$ Gerges, The Rise and Fall of Al-Qaeda, 59.
} 
fatwas and his statements on the creation and operations of this organization. ${ }^{323}$ The following table indicates a clearer image of al-Qaeda reflected in its ideology and founding declarations.

\begin{tabular}{|c|c|}
\hline The Problem & The American Invasion of Muslim lands \\
\hline The Enemy & Judeao-Crusader Alliance \\
\hline The Method & Global Jihad \\
\hline The Goal & Creating an Islamic Caliphate \\
\hline
\end{tabular}

When the building of the al-Qaeda organization with characteristics indicated above was completed, bin-Laden formally announced the establishment of the organization as a global jihadi front against the Americans, the Christians, and the Jews in February 1998. This was done through bin-Laden's second official fatwa entitled "the World Islamic Front Statement for Jihad against Jews and Crusaders" released on February $23,1998 .{ }^{324}$ Some scholars consider the announcement of the establishment of the World Islamic Front through this fatwa as the formal launch of alQaeda. ${ }^{325}$ This fatwas signaled the transformation of Islamism from domestic to global and the emergence of a new global "Islamist Militant Front" led by a transnational organization called alQaeda. It was the first time bin-Laden had made it clear that the enemy's civilians would be a target anywhere in the world: "obeying the order to kill the Americans and their allies, both civilian and military, is the duty of every Muslim." ${ }^{326}$ After the release of his second fatwa, bin Laden told the Pakistani press:

\footnotetext{
${ }^{323}$ See Bin Laden, "Declaration of War Against the Americans;" Shaykh Osama bin-Muhammad bin-Laden, et al., "World Islamic Front Statement: Jihad Against Jews and Crusaders," Federation of American Scientists, August 23, 1998 (http://fas.org/irp/world/para/docs/980223-fatwa.htm).

${ }^{324}$ Bin Laden, et al., "World Islamic Front Statement."

${ }^{325}$ Gerges, The Rise and Fall of Al-Qaeda, 56.

${ }^{326}$ Bin Laden, et al., "World Islamic Front Statement."
} 
"This front has been established as the first step to pool together the energies and concentrate efforts against the infidels as represented in the Judeo-Crusader alliance, thus replacing splinter and subsidiary fronts." ${ }^{327}$

The "Islamic Front" brought together at least five groups under the al-Qaeda umbrella, including Zawahiri's Islamic Jihad, the imprisoned Sheikh Rahman's Organization, the Egyptian Islamic Group which also represented a number of North African Islamist movements, the Pakistani Harakat ul-Ansar, and a Bangladeshi militant group. ${ }^{328}$ During the first years of its emergence, "al-Qaeda resembled a small and transient private army consisting of specialized and well-trained units," however, it slowly became a "militarily operational hierarchical organization" for training, supplying and financing jihadis of different origins and coordinating attacks on the United States and its allies. ${ }^{329}$ The organization was capable of building a cadre of 3000 operators by $2001 .^{330}$ The three following sections investigate and articulate the emergence of this organization within the levels of analysis framework, and thus, at three systematic levels.

\section{Individual Level: Personal Motivations}

At this level of analysis, scholars "suggest that individuals become aggressive when they feel frustrated by something or someone they believe is blocking them from fulfilling a strong desire." ${ }^{331}$ However, psychological approaches to terrorism studies reject the existence of any "particular terrorist personality," arguing that terrorist behavior is the result of an interconnection

${ }^{327}$ Corbin, Al-Qaeda, 67.

328 Ibid.

${ }^{329}$ Palmer and Palmer, Islamic Extremism, 148.

${ }^{330}$ Gerges, The Rise and Fall of Al-Qaeda, 59.

331 See Homer-Dixon, "On the Threshold," 104-105; L Berkowitz, Aggression: A Social Psychological Analysis (New York, NY: McGraw-Hill, 1962); J Dolard, L Doob, \& N. E. Miller, Frustration and Aggression (New Haven: Yale University Press, 1939). 
between an individual and its environment. ${ }^{332}$ Thus, terrorist behavior is the result of a relationship between an individual and the political, ideological and religious contexts that motivate an individual to demonstrate the behavior.

Individual psychology, according to these studies, is affected by social or group psychology that nurtures an individual's motivation towards terrorist behaviors in the first place. ${ }^{333}$ Post (2006), for instance, suggests that "terrorists are psychologically normal, in the sense of not being clinically psychopathic; they are neither depressed nor severely emotionally disturbed." ${ }^{334}$ Thus, terrorism is not the outcome of a psychological disorder. Rather, terrorists' individual and collective behavior is primarily the product of social, political and ideological contexts in which they live. ${ }^{335}$ Social psychology, in this sense, is "conceived as a context" which affects the individual psychology in producing a multiplicity of individual motivations, particularly a sense of revenge, a sense of gaining glory or significance, and a sense of giving power to the powerless. $^{336}$ These motivations cause someone to join and remain as a part of a terrorist organization. $^{337}$ Social psychology, therefore, provides a constructive framework for understanding individual-level causes of the formation of terrorist organizations. Social psychology, in this sense, affects individual psychology in producing individual motivations, including a sense of revenge, and a sense of gaining significance. ${ }^{338}$

\footnotetext{
332 John Horgon, "Understanding Terrorist Motivation: A Socio-Psychological Perspective," in Maping Terrorism Research: State of the Art, gaps and future direction, ed. Magnus Ranstorp (London and New York: Routledge, 2007), 107-109; Jerrold M. Post, "The Psychological Dynamics of Terrorism," in The Roots of Terrorism, ed. Louise Richardosn (New York and London: Routledge, 2006), 17-18.

${ }^{333}$ Jerrold M. Post. The Mind of the Terrorist: The Psychology of Terrorism from the IRA to Al-Qaeda (New York: Palgrave MacMillan, 2007), 4.

${ }_{334}$ Post, "The Psychological Dynamics of Terrorism," 18.

${ }^{335}$ Ibid.; Horgan, "Understanding Terrorist Motivation," 108-109.

${ }^{336}$ Post, "The Psychological Dynamics of Terrorism," 18.

${ }^{337}$ Post, The Mind of the Terrorist, 4.

${ }^{338}$ M Dugas, \& Arie W. Kruglanski, "The Quest for Significance Model of Radicalization: Implications for the Management of Terrorist Detainees," Behavioral Sciences and the Law, 32, 2014: 424-427; Arie W. Kruglanski, \& E. Orehek, "The Role of the Quest for Personal Significance in Motivating Terrorism," in J. Forgas, A. W.
} 
Social psychologists characterize these two motives as elements of a "universal human motivation" known as "the quest for significance." ${ }^{339}$ According to "the quest for significance" theory, motivated individuals mainly rely on collectivism as the most convenient approach for fulfilling their desire of revenge and gaining significance. ${ }^{340}$ Collectivism provides the individuals with a group identity, characterizes an in-group versus an out-group categorization, and describes the group's goal as the goal of individual members. ${ }^{341}$ The individuals, in turn, incorporate elements of the affiliated group into their own identity because "identification as a group member in itself endows a person with a sense of significance and empowerment." ${ }^{\prime 34}$

The process of group formation as a consequence of individuals' quest for significance is formulated more concretely by "self-categorization" and "uncertainty-identity" theories. These theories emphasize that individuals' desire for gaining significance forces them "to identify with groups, construe themselves and others in group terms, and manifest group behaviors." ${ }^{343}$ Because the process of categorizing oneself as members of a group effectively reduces the individuals' selfuncertainty by identifying them as part of something greater than themselves and by defining their distinct behavior as the practical reflection of the group's "distinctive and clearly defined beliefs and behavioral prescriptions. ${ }^{{ }^{3} 44}$

Kruglanski, \& K. Williams (Eds.), The Psychology of Social Conflict and Aggression: 153-166 (New York, NY: Psychology Press, 2011); Post, "The Psychological Dynamics of Terrorism," 18.

${ }^{339}$ Dugas, \& Kruglanski, "The Quest for Significance Model of Radicalization," 424.

${ }^{340}$ Kruglanski, \& Orehek, "The Role of the Quest for Personal Significance in Motivating Terrorism," 155-56.

${ }^{341}$ Dugas, \& Kruglanski, "The Quest for Significance Model of Radicalization," 428-29; Kruglanski, \& Orehek, "The Role of the Quest for Personal Significance in Motivating Terrorism," 153.

${ }^{342}$ Dugas, \& Kruglanski, "The Quest for Significance Model of Radicalization,” 428; W. B. Swann, A. Gomez, J Dovidio, S. Hart, \& J Jetten, "Dying and Killing for One's Group: Identity Fusion Moderates Responses to Intergroup Versions of the Trolley Problem," Psychological Science, 21, 2010: 1176-1183.

${ }^{343}$ M. H Hogg \& S A Reid, "Social Identity, Self-Categorization, and the Communication of Group Norms," Communication Theory, 16, 2006: 9.

${ }^{344}$ Dugas, \& Kruglanski, "The Quest for Significance Model of Radicalization,” 428; Hogg \& Reid, "Social Identity, Self-Categorization..." 
Thus, the process of "the quest for significance" leads individuals to form or attach themselves to a distinct group that prescribes distinctive behavioral norms. ${ }^{345}$ Group formation, in this sense, becomes a key element of the process of an individual's struggle for fulfilling their desire of gaining significance. The individual quest for significance includes multiple elements which vary in different circumstances. ${ }^{346}$ The most decisive factor in this regard is that whether individuals, prior to forming or becoming members of a group, experience "a sense of significance loss" or not. If individuals experience a significant loss, both vengeance and honor underlie the individuals' motivation for group formation. ${ }^{347}$

Regarding al-Qaeda, a "socially based significance loss" was experienced by individual jihadis prior to the formation of this organization. ${ }^{348}$ Therefore, their desire for creating al-Qaeda was primarily motivated by a sense of 'significance-restoring revenge. ${ }^{349}$ In other words, the formation of al-Qaeda, at the individual level, was motivated by jihadis' quest for personal security and their sense of revenge, and a desire for gaining significance. The two individual motivations were produced in a specific social and historical context in which thousands of trained Afghan Arabs were experiencing prosecution by their domestic regimes and witnessing the persecution and torture of their coreligionists from the Middle East to the Balkans and to Central Asia after the Cold War.

Following the withdrawal of the Soviet forces from Afghanistan, a number of Afghan Arabs returned home. But they were unwelcome and considered dangerous by their governments. They and their families and friends became under surveillance by their local regimes. Therefore,

\footnotetext{
${ }^{345}$ Kruglanski, \& Orehek, "The Role of the Quest for Personal Significance in Motivating Terrorism," 153.

${ }^{346}$ Dugas, \& Kruglanski, "The Quest for Significance Model of Radicalization," 425-26.

${ }^{347}$ Ibid., 424-27.

348 Ibid., 425.

${ }^{349}$ Ibid., 425-26.
} 
these jihadis were in search of personal security, from North Africa to the Balkans to South Asia, in the first place. In addition, the political environment in Muslim societies from the Middle East to South and Central Asia, to the Caucasus, to the Balkans was not pleasant in the early 1990s. Arabs in the Middle East had lost the support of the Soviets and as a result Israel had become an unchallenged regional power; in Central Asia and the Caucasus the new geopolitical situation put Muslims under Russia's attack; in the Balkans Muslims became victims of the Serbs' expansionism; and in many other places thousands of Muslims were killed and attacked by neighboring powers. ${ }^{350}$ Besides these "bitter experiences," the United States had intervened in the land of the two Holy Mosques, Saudi Arabia, which Islamists interpreted as a moral offense and the beginning of the domination of the abode of Islam by the remaining superpower. These conditions created and intensified a sense of revenge and wanting to fight back among jihadis, particularly among the experienced and motivated Afghan Arabs. These jihadis had concluded that the power and glory are taken from them, and that therefore they were obliged to start a global mission to return power and glory to the 'suffered and powerless' Muslims. Materialization of the jihadis' desire required leadership to draw together prosecuted, alienated, frustrated jihadis into a coherent organization and a safe haven to provide the prosecuted Afghan Arabs with space from which to manage their operations.

The role of leadership was played by bin Laden and Afghanistan provided the organization with a safe base. ${ }^{351}$ Bin Laden played a crucial role in bringing together the isolated, individually aggrieved and frustrated jihadis into a collective identity by providing a sense-making unifying message that conveyed a combined religious, ideological and political goal to his followers. ${ }^{352} \mathrm{He}$

\footnotetext{
${ }^{350}$ Murden, Islam, the Middle East and the New Global Hegemony, 195-197.

${ }^{351}$ Post, "The Psychological Dynamics of Terrorism," 21.

${ }^{352}$ Ibid.
} 
identified a common enemy, the US as the main cause of the post-Cold War problems in Muslim societies and described a jihadi action against it as a heroic and glorious method. ${ }^{353}$ The emergence of al-Qaeda, in this sense, did not only mean the rise of a concrete organization for revenge but also an organization for materializing an imagined glory. Therefore, becoming a member of alQaeda and supporting its cause was found to be attractive among experienced but prosecuted Afghan Arabs and as well as among alienated Muslim youth, many of whom sensitized in the madrassas and the post-Cold War 'bitter experiences. ${ }^{354}$

To be specific, the Afghan Arabs' search for personal security was the first individual-level cause of the formation of al-Qaeda. The insecure environment forced the aggrieved Afghan Arabs to rely on their ideology, Salafi-jihadism, in order to find a fluid and territorially flexible secure space, while their juridical identities and their citizenships did not offer anything but an identification for prosecution. Following the withdrawal of Soviet forces from Afghanistan, most of the Afghan Arabs, including bin Laden, returned to their countries of origin with the hope of strengthening local Islamist organizations or creating their own. ${ }^{355}$ Most of the ones who returned home were considered dangerous and therefore persecuted by their governments. Becoming aware of what their returned colleagues faced, some Afghan Arabs stayed in Afghanistan and Pakistan simply to hide from being prosecuted in their home countries. ${ }^{356}$ As a result, from the Middle East to the Balkans to South Asia thousands of Afghan Arabs were in search of personal security and a way to fight back. Bin Laden himself was under surveillance by the Saudi government after the

\footnotetext{
${ }^{353}$ Arthur J. Deikman, "The Psychological Power of Charismatic Leaders in Cults and Terrorist Oragizations," in The Making of a Terrorist: Recruiting, Training and Root Causes, ed. James J. F. Forest, vol. 2 (Westport, Connecticut, London: Praeger Security International, 2006), 82-83.

${ }^{354}$ Jerold, M Post, "When Hatred is Bred in the Bone: the Sociocultural Underpinnings of Terrorist Psychology," in The Making of a Terrorist: Recruiting, Training and Root Causes, edited by James J. F. Forest, vol. 2 (Westport, Connecticut, London: Praeger Security International, 2006), 25.

${ }^{355}$ Palmer and Palmer (2008), 132.

${ }^{356}$ Stenersen (2015), 131-34.
} 
regime realized that he was using his Saudi and Yemeni veterans to help create a jihadi group in Yemen, under the warlord Tariq al-Fadhli, who was fighting against Yemen's Communist government. ${ }^{357}$

Thus, like many other Afghan Arabs, bin Laden left his home country in search of a safe haven. Being aware of the general situation of other jihadis, he planned to collect the restless Afghan Arabs in a safe place and organize them for the next stage of jihad. By the end of 1990, he successfully collected a part of the Afghan Arabs and centered them in Sudan, where he was welcomed as a "Muslim investor" by the Islamist government of Omer al-Bashir. The primary steps to establishing al-Qaeda, in this sense, was taken by some alienated and prosecuted Afghan Arabs under a unifying leadership. They were specialized in war but were not able to open their own fronts in their home countries as they initially hoped. They were frustrated by the prosecution and alienated from their own societies. The only relationship they could rely on was the transnational 'brotherhood' and connections they had developed during the Afghan War. Therefore, they were potential members of a transnational militant organization with al-Qaeda lines in the early 1990s.

The second individual element that factored into the formation of al-Qaeda was the Islamists' sense of revenge against an external enemy, the United States. They considered America as the enemy because it maintained an "oppressive status quo" in the Middle East and invaded the holiest place of their religion in Saudi Arabia. Scholars such as Post (2006) argue that terrorist groups are primarily formed against a dominant party that was considered as the enemy. The party could be a government or an organization. The founding members of terrorist organizations hate any dominant party and aim to attack it collectively. The hate against a dominant party is mainly

${ }^{357}$ Corbin, Al-Qaeda, 31. 
the result of an oppressive circumstance under which these individuals grow and live. ${ }^{358}$ "The dominant party," in the case of al-Qaeda, was the United States which "maintained a status quo" in the Middle East that jihadis believed was preventing them from establishing Islamic states. By the 1990s, as jihadis met defeat at the hands of the government security apparatus in Egypt, Algeria and elsewhere, domestic rivalry escalated into a "tug-of-war."359 The unhappy Afghan Arabs considered their suffering as a result of an "American-sponsored status quo" in the Middle East under which secular states constantly prosecuted and tortured the Islamists. Hence, bin Laden and his lieutenants viewed America as the "evil" because of attacking Islam and blocking the success of the jihadis in the Muslim world. ${ }^{360}$ Following the collapse of the Soviet Union, the economic and military sponsor of many secular regimes in the Muslim world, every individual jihadi expected the immediate replacement of the Soviet's proxy allies with Islamic regimes. This did not happen and the Islamists characterized the US as the "evil" that advocated and maintained the “oppressive status quo." ${ }^{361}$ The rise of al-Qaeda, in this sense, was a direct product of a sense of revenge against the evil superpower. Bin Laden, personally, defined the US as the "evil force" that maintained the status quo in the Middle East and as the only force blocking the jihadis way to replace local regimes with "Quranic-based states" and ultimately the restoration of the Caliphate. ${ }^{362}$ Al-Qaeda primarily emerged as an ideal organization for a collective revenge in a global context. Jihadis throughout the world considered al-Qaeda as a vanguard army which could lead the global war between the world of Islam and the remaining superpower and, therefore, did not hesitate to join it. ${ }^{363}$

\footnotetext{
358 Post, The Mind of the Terrorist, 4.

${ }^{359}$ Gerges, The Far Enemy, 101.

${ }^{360}$ Palmer, and Palmer, Islamic Extremism, 147.

${ }^{361}$ Gerges, The Rise and Fall of Al-Qaeda, 59.

362 Ibid.

363 Ibid., 55, 77.
} 
The third root cause of the establishment of al-Qaeda, at this level of analysis, was the jihadis' motivation to gain significance and glory by "returning the power to the powerless and suffered" Muslims. As discussed, the end of the Cold War had bitter consequences in all Muslim regions. Many Afghan Arabs witnessed these facts when they moved from the battlefields of Afghanistan to their home countries in Bosnia, Palestine, Chechnya, Egypt and elsewhere. Thus, they were motivated and ready to wage battle on behalf of the 'powerless Muslims' worldwide and against their "imagined and real enemies." 364 This form of heroism, however, was not only the outcome this recent experience. It was also a "generational and societal dynamic which was seeded during the Afghan War." 365 The Afghan Arabs were "socialized" during the Afghan War to be heroic fighters and the only way to become one was to join the jihad in all forms. According to observers, as many as 25,000 jihadis, including bin-Laden, who joined the Afghan War in the 1980s were glory-seekers from the beginning. ${ }^{366}$ The path to glory during the Afghan War was adhering to a domestic and defensive jihad for liberating a Muslim nation from the Soviet Union. The path in the post-Cold War era was, however, considered a global and offensive battle on behalf of the whole Muslim world. The emergence of al-Qaeda, in this sense, was the result of jihadis' interest in this form of heroism and glory. Thus, together with personal security and a sense of revenge, heroism was the third determinant factor of the emergence of al-Qaeda at the individual level of analysis.

\footnotetext{
${ }^{364}$ Gerges, the Rise and Fall of al-Qaeda, 67.

${ }^{365}$ Post, "The Psychological Dynamics of Terrorism," 20-21.

${ }^{366}$ Corbin, Al-Qaeda, 16.
} 


\section{Group Level: Salafi-Jihadism}

Salafi-Jihadism, as a group ideology, is the most significant element of al-Qaeda's formation which had a determinant effect on the emergence of the organization. Ideology, as a belief system and a shared reality, helps individuals to formulate and reinforce a sense of "we-ness" or a group identity. ${ }^{367}$ While some have doubted the role of ideology in the emergence of terrorist groups, ${ }^{368}$ a review of the founding declarations and documents of major extremist Islamist groups indicates the determinant role of Salafi-Jihadism on the creation of those groups. ${ }^{369}$ The two founding fatwas of al-Qaeda, for instance, are hardly more than manifestations of the Salafi-Jihadi ideology. ${ }^{370}$ The four key elements of the "far-enemy-centrist" Salafi-Jihadism, as articulated in the previous chapter, are clearly expressed in al-Qaeda's declarations and its leadership's statements, and interviews. The "World Islamic Front" statement (1998), for instance, describes "the crusader armies' domination of the Muslim lands" as the problem. The crusader armies in this phrase refers to the US troops stationed in the Saudi Arabia:

"The Arabian Peninsula has never...been stormed by any forces like the crusader armies spreading in it like locusts, eating its riches and wiping out its plantations. All this is happening at a time in which nations are attacking Muslims like people fighting over a plate of food." 371

\footnotetext{
${ }^{367}$ Dugas, \& Kruglanski, "The Quest for Significance Model of Radicalization," 427; Homer-Dixon, "On the Threshold," 105.

${ }^{368}$ Marc Sageman, Leaderless Jihad: Terror Networks in the Twenty-First Century (Philadelphia, PA: University of Pennsylvania Press, 2008); Pape, Dying to Win.

${ }^{369} \mathrm{Al}$-Adnani, "ISIS spokesman declares Caliphate, Rebrands group as "Islamic State;" Al-Zawahiri, "His Own Words;" Bin Laden, "Declaration of War Against the Americans Occupying the Lands of the Two Holy Places;" Bin Laden et al., "World Islamic Front Statement."

${ }^{370}$ Bin Laden, "Declaration of War Against the Americans Occupying the Lands of the Two Holy Places;" Bin Laden et al., "World Islamic Front Statement: Jihad Against Jews and Crusaders."

${ }^{371}$ Bin Laden et al., "World Islamic Front Statement."
} 
Likewise, the statement characterizes the United States and its allies as the "enemy" and an offensive and global jihad as the method:

“...All these crimes and sins committed by the Americans are a clear declaration of war on Allah, his Prophet, and Muslims... The ruling to kill the Americans and their allies - civilians and military - is an individual duty for every Muslim who can do it in any country in which it is possible to do it." ${ }^{372}$

Finally, although al-Qaeda initially supported campaigns against false Muslim rulers (e.g. Saudi Arabia, Egypt, Uzbekistan, etc.), its ultimate goal is the re-establishment of 'the Caliphate,' an Islamic state ruled by Sharia. ${ }^{373}$ Statements from Bin Laden, Zawahiri, Zarqawi, Sayf al Adl, and other al-Qaeda leaders display the uncompromising commitment of al-Qaeda's leaders to the ideological agenda of the creation of an Islamic state. ${ }^{374}$

In addition to using Salafi-Jihadism as an underlying doctrine, the al- Qaeda leadership used Salafi-Jihadism to legitimize the organization's violent method and its objectives. For using this ideology as a religious cover to al-Qaeda's violent philosophy and method, Bin Laden formed a 'committee' of more religiously trained Islamists within al-Qaeda. The committee members were basically assigned to codify and justify, with fatwas, al-Qaeda's method and objectives. ${ }^{375} \mathrm{Al}-$ Qaeda's founding fatwas were mainly written by this committee. The number of references to early Salafi scholars in al-Qaeda's founding fatwas indicates a deep reliance of the religious committee to the Salafi literature, particularly the early Salafi scholars. Ibn Taymiyyah (12631328), for instance, is directly quoted five times in the "Declaration of War against the Americans

\footnotetext{
372 Bin Laden et al., "World Islamic Front Statement."

${ }^{373}$ Gunaratna, Inside al-Qaeda, 55.

${ }^{374}$ Christopher M. Blanchard, "Al-Qaeda: Statements and Evolving Ideology," CRS Report for Congress, 2007, 15, available at https://fas.org/sgp/crs/terror/RL32759.pdf

${ }^{375}$ Corbin, Al-Qaeda, 37.
} 
Occupying the Land of the Two Holy Places. ${ }^{״ 376}$ These fatwas first provided an image of the world politics in which Muslims are attacked by the outsiders and experienced a loss of significance. Next, they developed a religious justification for a global jihad, the establishment of a global jihadi organization as a vanguard army which would lead Muslims in the war against the invaders. ${ }^{377}$ More specifically, the first fatwa announced the beginning of a global jihad from Afghanistan, and the second fatwa announced the emergence al-Qaeda.

"By the Grace of Allah, a safe base is now available in the high Hindukush mountains in Khurasan; where-by the Grace of Allah-the largest infidel military force of the world was destroyed...Today we work from the same mountains to lift the iniquity that had been imposed on the Ummah by the Zionist-Crusader alliance...Ibn Taymiyyah, after mentioning the Moguls (Tatar) and their behavior in changing the law of Allah, stated that: 'the ultimate aim of pleasing Allah, raising His word, instituting His religion and obeying His messenger is to fight the enemy, in every aspect and in a complete manner." 378 "To kill the Americans and their allies - civilians and military ... is in accordance with the words of Almighty Allah: 'and fight the pagans all together as they fight you all together, and fight them until there is no more tumult or oppression, and there prevail justice and faith in Allah.' We [the world Islamic front] call on every Muslim who believes in Allah and wishes to be rewarded to comply with Allah's order."”379

Salafi-Jihadism, in this sense, had a profound impact on the establishment of al-Qaeda and played a crucial role in providing religious justification to its violent philosophy and operational method.

\footnotetext{
${ }^{376}$ Bin Laden, "Declaration of War Against the Americans Occupying the Land of the Two Holy Places."

${ }^{377}$ Ibid.; Bin Laden et al., "World Islamic Front Statement."

${ }^{378}$ Bin Laden, "Declaration of War Against the Americans Occupying the Land of the Two Holy Places."

${ }^{379}$ Bin Laden et al., "World Islamic Front Statement."
} 
The two founding fatwas are, in fact, two religious statements that justify the need for the establishment of a global jihadi organization legitimizing the organization's philosophy and its armed method by referring to Islamic texts. ${ }^{380}$ The Salafi-Jihadist ideology, in this sense, functioned as a determining factor at the group level which put individually motivated jihadists in a specific direction and ultimately resulted in the formation of a 'religiously defendable' organization. Accordingly, Salafi-Jihadism provided both the cause of the formation of al-Qaeda at the group level and a sense-making system that justified the group's philosophy. Without this ideology, individual level efforts to create an operational organization might have resulted in the formation of a series of groups with different characteristics.

\section{International Level: System Shift and Its Consequences}

Theories belonging to this level of analysis describe international causes as "external constraints" that encourage and even compel actors to form groups and engage in war. ${ }^{381}$ Concerning this case study, two international factors, the transformation of the international system from bipolarity to unipolarity ${ }^{382}$ and its international and regional consequences in the Middle East and South Asia, functioned as the root causes of the rise of al-Qaeda at this level of analysis. The two factors were conceived by jihadis as "external constraints" that had imposed an oppressive circumstance on them and their societies, preventing the formation of Sharia-based states in the Muslim world. ${ }^{383}$ The formation of al-Qaeda, in this regard, was a response to those constraints. Therefore, the

\footnotetext{
${ }^{380}$ Corbin, Al-Qaeda, 37.

${ }^{381}$ Choucri \& North, Nations in Conflict; Homer-Dixon, "On the Threshold," 105; Waltz, Theory of International Politics.

${ }^{382}$ Nuno Monteiro, Theory of Unipolar Politics (New York: Cambridge University Press, 2014); William C. Wohlfoth, "The Stability of Unipolarity," International Security 24/1 (Summer 1999): 5-41.

383 See Bin Laden, "Declaration of War Against the Americans Occupying the Land of the Two Holy Places;" Bin Laden et al., "World Islamic Front Statement;" Palmer, and Palmer, Islamic Extremism, 147.
} 
international level cause of the formation of al-Qaeda was the outcome of an international condition produced in the aftermath of the Cold War in the early 1990s.

Although the Soviet invasion of Afghanistan in 1979 planted the seeds of a transnational jihad, it did not directly cause the emergence of al-Qaeda as we know it since the 9/11 attacks. In addition to a series of reasons articulated earlier in this chapter, unlike al-Qaeda, its predecessors (i.e. MaK and AQA) were not anti-American and global jihadi organizations but they were conceived as parts of a resistance movement against an occupying force, the Soviet Union, in a Muslim territory, Afghanistan. ${ }^{384}$ Therefore, we cannot consider the Afghan War as a direct cause of the emergence of al-Qaeda, nor do I claim that al-Qaeda evolved directly from AQA which was active in the 1980s. Rather, the Soviet invasion could be evaluated as a "transcendent phenomenon" which activated the causal actions ${ }^{385}$ instead of directly factoring in the formation of al-Qaeda. In this context, the Afghan War, in the early 1980s, bred a new generation of jihadis, who felt empowered by the Soviets' defeat and were ready for a prolonged war. Accordingly, the Afghan war produced potential actors rather than direct causes.

Prior to the Soviet Union's invasion of Afghanistan, there had never been a journey of so many Muslims from so many countries to a Muslim country to fight together against a common enemy in modern history. There were Egyptians, Saudis, Yemenis, Palestinians, Algerians, Sudanese, Iraqi Kurds, Kuwaitis, Turks, Jordanians, Syrians, Libyans, Tunisians, Moroccans, Lebanese, Pakistanis, Indians, Indonesians, Malaysians, and others. ${ }^{386}$ Thus, the presence of such a widely representative group of Muslim fighters transformed the Afghan war into a religious

\footnotetext{
${ }^{384}$ Natasha Underhill, Countering Global Terrorism and Insurgency: Calculating the Risk of State Failure in Afghanistan, Pakistan, and Iraq (London: Palgrave 2014), 61.

${ }^{385}$ Van Evera, Guide to Methods for Students of Political Science, 16.

${ }^{386}$ Gerges, The Far Enemy, 82.
} 
struggle between the Ummah and the Godless Communism. ${ }^{387}$ The Afghan war, in this regard, created a generation of Islamists that were radicalized during the war and practiced transnationalism during their stay in Afghanistan. This generation was radicalized particularly by their interaction with organized jihadi groups such as the Egyptian Islamic Jihad, the Egyptian alJama'a al-Islamiya also known as the Islamic Group, Algerian Islamist groups, Pakistani Jamaati-Islami, Kashmiri Harakat ul-Ansar, and others who fought alongside Afghan jihadi groups against the Soviet Army. ${ }^{388}$ The Afghan War, in this sense, had an "overall radicalizing impact on foreign combatants and served as a transformative experience on both hardened jihadis like Azzam, Abu Ubaida al-Bansihiri, Abu Hafs, Seif al-Adl, Zawahiri and their cohorts, as well as on younger ones like bin-Laden." ${ }^{n 89}$ Following the withdrawal of the Soviet Army from Afghanistan in the late 1980s, inspired by lessons and experiences of the war, bin Laden concluded that "poorly armed but dedicated men can confront better-equipped adversaries." ${ }^{390}$ In a 2000 video, he used the Afghan War as a model to fight the remaining superpower, the United States:

"Using very merge resources and military means, the Afghan mujahidin demolished one of the most important human myths in history and the biggest military apparatus. We no longer fear the so-called Great Power. We believe that America is much weaker than Russia... America's nightmare in Vietnam and Lebanon will pale by comparison with the forthcoming victory in al-Hijaz [referring to the western provinces of Saudi Arabia were Mecca and Medina are located]. ${ }^{391}$

\footnotetext{
${ }^{387}$ Gerges The Far Enemy, 82

${ }^{388}$ Ibid., 84.

${ }^{389}$ Ibid.

${ }^{390}$ Ibid., 84-85.

${ }^{391}$ Ibid., 85.
} 
Other Islamists, too, referred to the Afghan War as a model of fighting Great Powers. Zawahiri, for instance, in his Knights Under the Prophet's Banner first published and serialized by the Saudi newspaper al-Sharq al-Awsat in October 2001, writes:

"The jihad battles in Afghanistan destroyed the myth of a superpower in the minds of young Muslim mujahidin. The Soviet Union, a superpower with the largest land army in the world, was destroyed and the remnants of its troops fled Afghanistan before the eyes of the Muslim youth and their participation." 392

The Afghan War, therefore, prepared the manpower - an inspired, radicalized and empowered generation - to a potential al-Qaeda. More concretely, it nurtured a generation of Islamists who were ready to be organized in an organization with al-Qaeda lines. Nonetheless, the Afghan War did not directly lead to the emergence of al-Qaeda. Although the seeds of transnational extremist Islamism were planted in the Afghan soil in the 1980s, extremist Islamists created a formal organization and began to articulate an operational blueprint to justify attacking the far enemy only in the mid-1990s. ${ }^{393}$ The Afghan War provided some antecedent conditions for the emergence of al-Qaeda but the formal establishment of this organization depended directly on two immediate causes, the international system shift, and its international political consequences. Accordingly, the major international factor which produced the direct causes of the emergence of al-Qaeda was the international transformation from bipolarity to unipolarity in the early 1990s and its consequences particularly in the Middle East and South Asia.

During the Cold War, the relations of the two Superpowers with their proxy allies in the Muslim world defined the regional order and thus the friend and enemy lines. The USSR sponsored mostly the Arab secular regimes while the US supported, in general, conservative Monarchies and

\footnotetext{
392 Ibid., 84.

393 Ibid., 86.
} 
used Islamist groups against the USSR and its moral ally in Muslim countries, the nationalist secular regimes. ${ }^{394}$ None of the two superpowers, in this period, had a total dominance on the Muslim world affairs. Their influence in Muslim regions was balanced by their comparative influence in different states. Following the collapse of the Soviet Union, the United States achieved "a total dominance of the Middle Eastern affairs not seen since that of the British in the first half of the twentieth century." ${ }^{395}$ With this systemic shift, the regional balance of power in the Middle East disrupted. Most of the secular regimes lost their international supporter and the United States turned into the sole great power in international relations with an unchallenged "intervening power." 396 The United States used its intervening power during the second Gulf War (1990-1991) by deploying its troops in the Middle East and stationing them in Saudi Arabia.

The Gulf War put the United States in a stronger position in the region. Before the Gulf War most of the Golf states did not intend to display their sympathy for the United States in regional affairs. But when the Gulf War began, Kuwait automatically became "a de facto protectorate of the US" and the US stationed its troops in Saudi Arabia. ${ }^{397}$ In general, the United States maintained a "permanent Gulf establishment of over 20,000 men and women, with at least three fighter squadrons and a carrier battle group on the station." 398 From this new base, the sole great power could move to construct a new regional order in which US power was institutionalized in an "Arab-Israeli peace process, an upgraded alliance system, and a much greater US military presence." 399 The United States had two main purposes of stationing its troops in the Gulf region: First, the maintenance of a secure Israel; second, the security of oil supplies for the industrialized

\footnotetext{
${ }^{394}$ Mamdani, Good Muslim, Bad Muslim,120. See also Gerges, The Rise and Fall of Al-Qaeda, 48

${ }^{395}$ Murden, Islam, the Middle East and the New Global Hegemony, 47; Zunes, "The United States: A Hegemon Challenged," 73.

396 Zunes, "The United States: a hegemon challenged," 73.

${ }^{397}$ Murden, Islam, the Middle East and the New Global Hegemony, 47; Gerges, the Rise and Fall of al-Qaeda, 49.

398 Zalmay Khalilzad and David Ochmanek, "Rethinking US Defence Planning," Survival 39/1 (Spring 1997):53-54.

${ }^{399}$ Murden, Islam, the Middle East and the New Global Hegemony, 48.
} 
world. ${ }^{400}$ The United States' new strategy in the Middle East and its increasing militarization of the region increased the anti-American reaction from Muslims, particularly Islamist communities. ${ }^{401}$

Some Islamists, Osama bin-Laden in particular, viewed the United States' intervention in the region as part of the "American post-Cold War scheme" to invade the region, establishing its military bases all over the Muslim world. ${ }^{402}$ The stationing of American troops in Saudi Arabia, in particular, had significant effects in confronting Islamists with the United States. It turned Islamists on both the US and the Saudi regime. By stationing its troops in Saudi Arabia, the US had crossed the "sensitivity lines" and by allowing it Saudi rulers had violated their "religious oath." ${ }^{403}$ Bin Laden and other Islamists declared the stationing of a non-Muslim troops in the land of the two Holy Mosques an offense against the fundamentals of their faith by referring to the Prophet who stated: "let there be no two religions in Arabia." 404 Many Saudi Islamists interpreted the statement as non-Muslims should not live anywhere on the Arabian Peninsula. ${ }^{405}$ According to a leading Saudi Islamist, Dr. Sa'ad al-Faqih, Americans did not consider Muslims' sensitivity about the land of the two Holy Mosques by bringing their troops in: "during the 1990 Gulf crisis the US crossed the psychological barriers by bringing in their forces. They failed to remember the sensitivity." ${ }^{406}$ The US stationing of its troops in Saudi Arabia and its interference in the Middle East were addressed through the manifesto of the "World Islamic Front" under al-Qaeda as the main reason for establishing the coalition and fighting in a unified front:

\footnotetext{
${ }^{400}$ Murden, Islam, the Middle East and the New Global Hegemony, 47

${ }^{401}$ Zunes, "The United States: a hegemon challenged," 77.

${ }^{402}$ Gerges, The Rise and Fall of Al-Qaeda, 49; Gerges, The Far Enemy, 146.

${ }^{403}$ Gerges, The Far Enemy, 148.

${ }^{404}$ Corbin, Al-Qaeda, 27.

${ }^{405}$ Ibid.

${ }^{406}$ Ibid., 28.
} 
"For more than seven years the US has been occupying the lands of Islam in the holiest of places, plundering its riches detaching to its rulers, humiliating its people, terrorizing its neighbors and turning its bases in the peninsula into a spearhead through which to fight the neighboring Muslim peoples." ${ }^{407}$

Thus, stationing of American troops in Saudi Arabia was a catalyst in unifying the anti-American voices toward establishing an anti-American front. Because of its "sensitivity," the case of Saudi Arabia provided jihadis with a justifying rhetoric for organizing a unified anti-American front in order to fight the occupying force. The Islamist reaction to the US post-Cold War strategy in the Middle East was followed by other events. The US intervention in Somalia in 1992 caused another reaction among Islamists. The reaction of bin-Laden's religious committee to the case of Somalia, for example, was as:

"They already took the Gulf area and now they go to Somalia. If they succeed, it could be the South Sudan next and they could take all the Islamic countries." 408 Thus, the new world order put the United States and Islamists in a direct confrontation, leading the Islamists to reinterpret the 'enemy' and 'the abode of war,' and to develop a new strategy and an organization to operationalize the strategy. This, in general, turned Islamists against the US and transformed the post-Qutbian domestic jihad into al-Qaeda's transnational jihadism. ${ }^{409}$

The international system shift had a number other consequences in Muslim regions including in the Middle East and South Asia which had a direct impact on the formation of alQaeda. Its impact in the Middle East, the Balkans, Central Asia and East Asia on the formation of al-Qaeda is discussed at the individual level of analysis indicating how those experiences

\footnotetext{
${ }^{407}$ Iibid., 67.

408 Ibid., 42.

${ }^{409}$ Gerges, The Rise and Fall of Al-Qaeda, 34.
} 
motivated individual jihadis to move toward the formation of a global jihadi front. The regional consequence of the international system shift in South Asia, however, had a more direct impact on the formation of the al-Qaeda organization in Afghanistan. The international system's transformation affected Afghan and regional politics, and as well as international politics in the region. This outcome can be discussed in three contexts: the Afghanistan context, the regional context, and the international context. In the Afghanistan context, it resulted in the defeat of the pro-Soviet Afghan government and the outbreak of a civil war among Afghan mujahidin groups. In the regional context, it turned Afghanistan into a focal point of regional competitions, particularly between Pakistan and India. In the international context, the systemic shift affected US foreign policy in the region, particularly in Pakistan and Afghanistan. The US disengaged from the two countries immediately after the collapse of the Afghan central government in April 1992. ${ }^{410}$ These three factors, together, resulted in the emergence of the Taliban, a jihadi group which fundamentally contributed to the establishment of al-Qaeda in Afghanistan.

In the Afghanistan context, following the defeat of the pro-Soviet PDPA regime in Afghanistan in April 1992, a bloody civil war among the victorious mujahedeen groups broke out. These groups initially fought over governmental resources, state establishments, and strategic areas in the Capital Kabul. Beyond Kabul, new power centers emerged in different parts, dividing the country into five military zones ruled by different ethnic militia groups. ${ }^{411}$ These groups, in turn, represented different regional powers. Most important among all were the pro-Pakistani Hizb-i-Islami of Pashtuns and Jamiat-e-Islami of Tajiks which was sympathetic to India. After the fall of the pro-Soviet Afghan government, Pakistan quickly engineered a so-called broad-based

\footnotetext{
${ }^{410}$ Elizabeth Could and Paul Fitzgerald, Crossing Zero: The Afpak War At The Turning Point of American Empire (New York: Open Media Series | City Lights Books, 2011), 86; Anwar Iqbal, "U.S Senate Warns Against Disengagement From Afghanistan," Dawn, October 28, 2014 (http://www.dawn.com/news/1140861). ${ }^{411}$ William Maley, The Afghanistan Wars, $2^{\text {nd }}$ Edition, (London: Palgrave Macmillan, 2009), 173-174.
} 
government of the mujahidin in which the only party Pakistanis did not favor, Jamiat-e-Islami, had managed to take control of Kabul. Feeling slighted by the 'usurpation' of power by the nonPashtun groups from the traditionally Pashtun rulers, Pakistan urged Hizb-i-Islami to take control of the capital from Jamiat-e-Islami militarily, resulting in a heavy bombardment of Kabul and extension of the civil war in Afghanistan. Nevertheless, Hizb-i-Islami failed to capture Kabul and Pakistan had to replace it with another party, the Taliban, as its proxy group in Afghanistan. The Taliban, which emerged in 1994 in the southern province of Kandahar, captured the capital Kabul in September 1996 and named their government the Islamic Emirate of Afghanistan (IEA). The Taliban's rule in Afghanistan facilitated the emergence of al-Qaeda by avoiding to disturb bin Laden and his followers' activities in Afghanistan's territory. The Taliban, mainly, because of its financial and military reliance on Bin Laden, granted him with a safe haven in Afghanistan where he initially created his mushrooming training camps and ultimately activated the al-Qaeda organization. ${ }^{412}$ In addition to its financial and military reliance on Arab jihadis, the ideological ties between the Taliban leadership and Bin Laden greatly facilitated the development of al-Qaeda in Afghanistan. The ideological ties and 'spiritual' brotherhood between the Taliban and Arab jihadis are expressed in many historical events and documents. At the end of a 1997 meeting between Bin Laden and the Amir of the Taliban, Mullah Mohamad Omar, for instance, Omar emphasized his jihadi brotherhood with Bin Laden by telling him: "you are a Mujahid. This is your

\footnotetext{
${ }^{412}$ Mohamed Mahmoud Ould-Mohamedou, Understanding al-Qaeda: The Transformation of War (London: Pluto Press, 2007), 49; Ahmad Rashid, "Afghanistan Resistance Leader Feared Dead in Blast," The Telegraph, 2001, September 11.

Retrieved from http://www.telegraph.co.uk/news/worldnews/asia/afghanistan/1340244/Afghanistanresistanceleader-feared-dead-in-blast.html; J. Roth, D. Greenburg \& S. Wille, "Al-Qaeda's Means and Methods to Raise, Move, and Use Money," National Commission on Terrorist Attacks upon the United States: Terrorist Financing Staff, 2004, 28. Retrieved from http://govinfo.library.unt.edu/911/staff_statements/911_TerrFin_Ch2.pdf; Barnet R. Rubin, The Fragmentation of Afghanistan (New Haven, CT: Yale University Press, 2002), xv.
} 
country and you are welcome to do whatever you like. ${ }^{״ 413}$ Likewise, in an interview in 2001, Bin Laden characterized his relationship to Omar as not a personal relationship, but a 'spiritual' one:

"I have a spiritual relationship with Mulla Omar. He is a great and brave Muslim of this age. He does not fear anyone but Allah. He is not under any personal relationship or obligation to me. He is only discharging his religious duty." ${ }^{414}$

In the regional context, the international system shift turned Afghanistan into a focal point of regional rivalries, particularly between Pakistan and India. Afghanistan has a historical border dispute with Pakistan and therefore all Afghan governments, since the creation of Pakistan in 1947, have been sympathetic to India. In other words, the Afghan governments, in all of its varieties, were always pro-India, and thus anti-Pakistan. Pakistan, on the other hand, in order to balance India's regional power, has set up proxy warfare in the Indian state of Jammu and Kashmir by regularly using Islamist groups. Pakistan has also sponsored extremist militant groups in Afghanistan in support of its doctrine of "strategic depth" in this country. Pakistan has historically produced, sponsored and used a series of extremist Islamist groups for countering a possible Afghan-Indian alliance in the region. Pakistan used the Mujahedeen and the Taliban in Afghanistan in different periods, and Jaish-e-Muhammad (Army of Muhammad) and Lashkar-iTaiba in Kashmir as its proxy allies. ${ }^{415}$ Islamist groups, in this sense, were used both as paramilitary branches of the Pakistani army and as its foreign policy instrument in the region. Almost all Islamist groups produced by Pakistan share a common ideological ground with alQaeda by entirely relying on Islamism. These groups, in turn, contributed to the emergence and

\footnotetext{
${ }^{413}$ Gerges, the Rise and Fall of al-Qaeda, 62-63.

${ }^{414}$ Osama Bin Laden, "Interview with Hamid Mir," Dawn, 2001, November, 10. Retrieved from http://www.dawn.com/news/5647/

415 John Moore, "The Evolution of Islamic Terrorism: An Overview," PBS

(http://www.pbs.org/wgbh/pages/frontline/shows/target/etc/modern.html).
} 
development of al-Qaeda in Afghanistan and Pakistan in terms of providing the terrorist organization and its operatives with safe havens, training and recruiting facilities and networking mediums.

In the international context, the international system transformation had a remarkable impact on US foreign policy in the region, particularly in Afghanistan and Pakistan. At the end of the Cold War, the United States along with a number of major European states disengaged from Afghanistan and Pakistan. ${ }^{416}$ Therefore, the international community's interest in the region decreased dramatically. Thus, the United States and the European Union did not have any interest in Afghanistan when the Taliban emerged. Until its defeat through the American-led Operation Enduring Freedom in late 2001, the Taliban's IEA was recognized by only Pakistan, Saudi Arabia, and the Arab United Emirates. Lacking a formal relationship with the free world, the IEA did not consider itself accountable to the international community. When Bin Laden began establishing its training camps and the al-Qaeda organization in Afghanistan in 1996, he did not face any serious domestic or international obstacle. Al-Qaeda emerged before the eyes of a dominant Islamist group, the Taliban, which did not have any ideological antagonism with al-Qaeda's philosophy. In addition to the IEA's facilitation of the development of al-Qaeda in Afghanistan, Pakistan, the Taliban's sponsor, did not show any interest in questioning al-Qaeda activities in Afghanistan. Rather, Pakistan considered al-Qaeda as a militant Islamist group in favor of its conventional regional politics. Pakistani strategists had calculated that they could use al-Qaeda, like other extremist groups, for their regional games and even their further strategic ambitions toward Central Asia. Although the Pakistani government has constantly denied harboring the extremist groups, evidence proves the Pakistani establishment's direct role in creating and

\footnotetext{
${ }^{416}$ Elizabeth Could \& Paul Fitzgerald, Crossing Zero: The AfPak War at the Turning Point of American Empire (New York, NY: Open Media Series, City Lights Books, 2011), 86.
} 
supporting domestic SJGs groups including the Taliban which contributed to the formation and expansion of al-Qaeda. ${ }^{417}$

\footnotetext{
${ }^{417}$ From [Excised] to DIA Washington D.C. [Excised], Cable "[Excised]/Pakistan Interservice Intelligence/ Pakistan (PK) Directorate Supplying the Taliban Forces." Secret, National Security Archive at George Washington University, October 22, 1996 http://nsarchive2.gwu.edu//NSAEBB/NSAEBB227/15.pdf; From [Excised] to DIA Washington D.C. "IIR [Excised] Pakistan Involvement in Afghanistan." Confidential, National Security Archive at George Washington University, November 7, 1996, http://nsarchive2.gwu.edu//NSAEBB/NSAEBB227/17.pdf; Mori DocID: 800277. "Secret, Noforn [Excised - Released by U.S. Central Command]." National Security Archive at George Washington University. http://nsarchive2.gwu.edu//NSAEBB/NSAEBB227/15.pdf; Carlotta Gall, "Pakistan's Hand in the Rise of International Jihad," the New York Times, February 6, 2016 http://www.nytimes.com/2016/02/07/opinion/sunday/pakistans-hand-in-the-rise-of-internationaljihad.html?mwrsm=Facebook\& $\mathrm{r}=1$
} 


\section{IV}

\section{State Fragility in Afghanistan and the Rise of al-Qaeda}

The three-level root causes, as discussed in the previous chapter, were determinant factors of the formation of al-Qaeda. However, the organization's establishment as a network of connected operational units, training camps and informal relationships around a hierarchical core group was conditioned by specific aspects of state fragility in Afghanistan in the 1990s. The idea of al-Qaeda was materialized under these conditions. All three measures of state fragility (i.e. lack of legitimacy, weak authority and poor capacity) in Afghanistan in the 1990s were effective in this regard. Comparative evidence indicates that the root causes at three levels of analysis, as articulated, could not factor into the formation of al-Qaeda in the absence of the aforementioned state fragility conditions. The persistence of the three-level causes in Saudi Arabia, for instance, did not prodce al-Qaeda. Bin Laden and his Saudi militants neither could freely network nor could they gather with jihadis of other nations within the Saudi territory. Although Saudi Islamist militants attempted to form an operative jihadi organization in Arabia but failed due to the state's strong security apparatus and its authority over the country's territory, borders, and population. ${ }^{418}$ In contrast, specific aspects of state fragility in Afghanistan, one of the seven most severely fragile states of the world in the $1990 \mathrm{~s},{ }^{419}$ made the emergence of al-Qaeda possible.

When bin Laden and his militants arrived in Afghanistan in 1996, the Afghan state was highly fragile with the Taliban's Islamic Emirate of Afghanistan (IEA) being involved in an ever-

\footnotetext{
${ }^{418}$ Corbin, Al-Qaeda, 27.

${ }^{419}$ Robert I. Rotberg. "The New Nature of Nation-State Failure,” the Washington Quarterly 25(3), $2002: 90$.
} 
intensifying civil war with its internal rival, the Northern Alliance (NA), also known as the National United Front for the Salvation of Afghanistan. The NA was an alliance of former jihadi and rebel groups mainly based in northern and central parts of Afghanistan which led the Islamic State of Afghanistan (ISA) vis a vis the IEA in the 1990s. The IEA was a "war-making" organization. Despite its specialty at war, the IEA was incapable of eliminating its internal rival, militarily. ${ }^{420}$ The IEA invested and concentrated massively in 'war-making' with the purpose of "state-making" but it never enjoyed the capacity and, particularly, the sufficient war machine to eliminate its rival and acquire the means of building a legitimate state that could provide protection and welfare to its clients. ${ }^{421}$ The IEA manifested severe weakness in all three measures of statehood, including legitimacy, authority, and capacity. The IEA did not enjoy a broad-based legitimacy, it lacked sufficient military and security force to end the war and secure the country, and it was both institutionally and functionally incapable of fulfilling the basic duties of a sovereign state. Bin Laden's activity and Al-Qaeda's formation in Afghanistan significantly benefited from these shortages. This chapter focuses on how the three aspects of state fragility in the mid-1990s Afghanistan provided the conditions necessary for the establishment of al-Qaeda. However, in order to provide a broader image of the problem, the chapter begins with a historical discussion of trends and trajectories of state formation and state fragility in Afghanistan. This will explain how the state was formed and developed in Afghanistan, and what factors affected statehood in this country throughout its lifetime. This will bring to light the historical roots and aspects of state fragility in Afghanistan and provide a background context for testing the relationship between state fragility and the emergence of al-Qaeda in this country in the 1990s.

\footnotetext{
${ }^{420}$ Ibrahimi, “The Taliban's Islamic Emirate of Afghanistan: 'War-Making and State-Making' as an Insurgency Strategy," Small Wars \& Insurgencies 28(6), 2017: 947-972.

${ }^{421}$ Ibrahimi, "The Taliban's Islamic Emirate of Afghanistan.'
} 


\section{From State Formation to State Fragility}

Afghanistan was established as a consolidated territorial state in the 1880 s. The establishment of Afghanistan was the result of a one-and-a-half century long political development in an ethnically diverse region called Khorasan, beginning in 1749 by the Durrani Pashtun tribes, whose rule once extended from Kabul to New Delhi. Following the decades' long state-building campaign, the sovereign state of Afghanistan was formally established in the 1880s during the reign of Amir Abdurrahman Khan. The state was built on populations divided along ethnic, linguistic and religious lines. Based on language, ethnicity and religion, there are around twenty-five distinct groups in Afghanistan, with four being the most influential in the Afghan politics, i.e., Pashtuns, Tajiks, Hazaras, and Uzbeks.

Political scientists believe that three social, political and military factors were the most effective contributors to the establishment of a sovereign state in Afghanistan. ${ }^{422}$ Socially, an "ethnic consciousness particularly among Pashtun tribes" grew gradually out of the internal anarchy and warfare that prevailed following the rise of Ahmad Shah Durrani, the founder of the Durrani Empire. ${ }^{423}$ It was at this time when Pashtun tribes emerged as the dominant ethnic group in Afghanistan, and with the creation of sovereign borders in the 1880s Afghanistan's “permanent minority groups were delineated." 424 Politically, the dual pressures of growing internal solidarities and external invasions from Imperial Russia and Great Britain led to wars, political manipulation, and construction of boundaries and the emergence of sovereign states in the region. ${ }^{425}$ Afghanistan was an outcome of this process. The external pressures by Britain and Russian Empires led to the

\footnotetext{
${ }^{422}$ Larry, P. Goodson, Afghanistan's Endless Wars: State Failure, Regional Politics, and the Rise of the Taliban (Seattle and London: University of Washington Press: 2001), 27.

${ }^{423}$ Goodson, Afghanistan's Endless Wars, 27.

${ }^{424}$ Richard F. Nyrop and Donald M. Seekins, eds. Afghanistan: A Country Study (Washington, DC: Foreign Areas Study, American University, 1986), 37-38; Goodson, Afghanistan's Endless Wars, 29.

${ }^{425}$ Goodson, Afghanistan's Endless Wars, 27.
} 
demarcation of new international boundaries which formed Afghanistan into a 'buffer state' that separated the two empires during the so-called Great Game. ${ }^{426}$ Militarily, Abdurrahman's tight relations with the British Indian government helped him to access larger amounts of gunpowder and firearms and refine the ancient martial tribal tactics of his army. This, in turn, made Abdurrahman's 'internal imperialism' possible. ${ }^{427}$ Following the demarcation of sovereign boundaries, Abdurrahman centralized power by subjugating all local actors and confining national decisions and policies in the capital, Kabul. ${ }^{428} \mathrm{He}$ destroyed and subordinated all regional power centers which had challenged the development of a central government in the nineteenth century. ${ }^{429}$ The process created a state structure that was divided along ethnolinguistic and tribal lines which made the development of a modern nationhood difficult. ${ }^{430}$ Therefore, the newly emerged state was essentially fragile. The state was formed as a thin surface over deep-rooted social, economic, and political realities that contradicted the consolidation of a uniform sovereign authority in a territorialized jurisdiction. The realities included social cleavages along linguistic, ethnic, tribal, and religious lines, the primacy of communal loyalties over loyalty to a higher-order identity, economic and topological underdevelopment which magnified the people's distance from the central government, and finally the country's geopolitical location which made the country a focal point of confrontation among regional powers. ${ }^{431}$ Those realities became steady factors of state fragility over the history of the state in Afghanistan. Different political regimes have hardly tried to overcome those problems but have invariably failed. The Afghan rulers, in general, have followed two general state-building policies to overcome the fragility of the Afghan state, namely,

\footnotetext{
${ }^{426}$ Barnett R. Rubin, The Fragmentation of Afghanistan (New Haven: Yale University Press, 2002), x.

${ }^{427}$ Goodson, Afghanistan's Endless Wars, 27.

${ }^{428}$ Thomas Barfield, Afghanistan: A Cultural and Political History, (Princeton University Press, 2010), 165-66.

${ }^{429}$ Barfield, Afghanistan, 165-66.

${ }^{430}$ Vartan Gregorian, The Emergence of Modern Afghanistan (Stanford: Stanford University Press, 1969).

${ }^{431}$ Goodson, Afghanistan's Endless Wars, 12-13.
} 
state conservatism and social transformation. The objective of both strategies was to enforce authority in different layers of the traditional society.

Political scientists and anthropologists believe that the core of the traditional social system in Afghanistan was the qawm, which could be any communal group, including extended family, tribe, ethnic group, village, and even a region or province. ${ }^{432}$ In traditional rural Afghanistan, "all meaningful social relations occurred within the qawm which was typically governed by jirga or shura." ${ }^{433}$ Shura means a council or assembly of elder males. In order to prevent the likelihood of violence and rebellion, the state had to impose laws and policies that did not contradict traditional social codes and consult it with local elders known as arbabs (or maliks in Pashtun areas). ${ }^{434}$ Arbabs referred to elder individuals chosen by the people and confirmed by the government. There were also cases in which arbabs were chosen by the government without consultation with people. ${ }^{435}$ Other significant local players were the khans, who were large landowners with local or even regional power. The traditional social system, based on qawm and jirga and ordered by traditional codes, always resisted modern bureaucracy and a unifying central rule. Considering the sensitivity of this system, Afghan rulers rarely tended to change it, but rather to rule it through its own codes and methods. Overall, in order to build a meaningful state in Afghanistan and overcome its severe fragility, the Afghan rulers used two general state-building policies which I call "state conservatism," and "social transformation" policies. The Musahiban dynasty (1930-1973) enforced the state conservative policy, and the People's Democratic Party of Afghanistan (ruled 1979-1992) applied the social transformation policy. The two policies are used, separately or as

\footnotetext{
${ }^{432}$ Louis Dupree, Afghanistan (Princeton: Oxford University Press, 1973), 183-193; Goodson, Afghanistan's Endless Wars, 19.

${ }^{433}$ Sayed Abdul Qudus, The Pathans (Karachi: Oxford University Press, 1958), 101; Goodson, Afghanistan's Endless Wars, 19.

${ }^{434}$ Nazif M. Shahrani and Robert L. Canfield, eds. Revolutions and Rebellions in Afghanistan (Berkeley: University of California, Institute of International Studies, 1984); Goodson, Afghanistan's Endless Wars, 19.

${ }^{435}$ Barfield, Afghanistan, 222.
} 
combined, by all political regimes that failed to build a cohesive sovereign authority in Afghanistan and, therefore, main sources of state fragility in contemporary Afghanistan can be traced in these policies.

\section{State-Building Policies: State Conservatism and Social Transformation}

The state conservatism strategy was the product of the Musahiban dynasty (1930-1973). According to this strategy, the state did not tend to interfere in local and intra-and-inter tribal issues leaving them as the internal business of qawms and jirgas. Local relations with the state was intermediated by khans and arbabs. In return for securing semi-autonomy in intra-and-inter tribal issues, khans and arbabs served as intermediaries between the state and qawm units supporting the state agents in law enforcement related issues. ${ }^{436}$ Under this policy, the state was urged to develop stability by maintaining its fragile relationship with traditional society and avoided any rapid sociopolitical change. This policy produced a two-track government, a formal government based in Kabul which acted on the basis of the state produced laws, and an informal semi-autonomous system of governance in the villages which functioned based on a customary law system.

Under King Zahir (1933-1973) the state was capable of avoiding major internal rebellions and external confrontation. The main state strategy was to develop a steady relationship with local intermediaries, i.e. khans and arbabs, and to avoid direct intervention in local and tribal issues. King Zahir followed two main purposes in his policy of increasing its relations with the local traditional elite: first, to prevent any form of political disorder by arbitrary law enforcement in traditional communities, and second, to extend its authority in Afghanistan by developing a partnership with socially rooted political forces. Thus, the state's authority and legitimacy in rural

${ }^{436}$ Thomas Barfield, Afghanistan: A Cultural and Political History (Princeton University Press, 2010), 221-222. 
Afghanistan remained highly dependent on a patron-client relationship between the state and the rural elite.

In practice, the state did not have sufficient authority and capacity to conduct its law enforcement duties in a regular manner. The state's major law enforcement institution was the gendarmerie police of the interior ministry which was poorly equipped and could hardly maintain sufficient order in the cities. ${ }^{437}$ Law enforcement tasks in the villages were assigned to "unarmed and ill-clothed police conscripts" called sipahi or hawaldaar. Since qawm networks provided their members with important networks of support outside official governmental channels, it was not possible to a sipahi to directly demand the surrender of a criminal suspect or to announce a governmental decision in the villages without the support of local khan or arbab. Relying largely on the means of those local intermediaries, the state sipahis acquired the ability to enter a community forcing an offender's family and relatives to deliver the offender. ${ }^{438}$ Thus, intermediaries were crucial elements of law enforcement in traditional society.

Parallel to the state system, there was a customary law system in the villages ruled by jirgas. ${ }^{439}$ The government accepted some jirga decisions in local levels as part of the deal between the state and social forces. Thus, Zahir's government pursued a strategy of "encapsulating traditional local institutions, rather than trying to penetrate the countryside and govern it." ${ }^{, 40}$ As a result, the state-society divide remained intact and the relationship between the two were poorly regulated and were mainly based on patron-client networks. Qawmi units were linked to the state only through personal ties performed by khans and arbabs.

\footnotetext{
${ }^{437}$ Ibid., 222.

${ }^{438}$ Ibid.

439 Ibid., 222-23.

${ }^{440}$ Rubin, The Fragmentation of Afghanistan, 20; 301.
} 
Despite the royal family's conservatism toward the rural society, the dynamics of political development in large cities changed in the early 1960s. A new political elite, educated in modern state-sponsored schools, pressured the monarchy demanding more political openness and civil rights. The pressure, ultimately, resulted in a constitutional adjustment and the transition of the state system from an "absolutist" monarchy to a parliamentary system in $1964 .{ }^{441}$ As a result, many political parties, belonging to all the political spectrum from the extreme right to the extreme left, including the pro-Soviet People's Democratic Party of Afghanistan (PDPA), the Maoist-oriented Progressive Youth Organization, and the Islamist Muslim Youth Organization were born in this period. Members of the newly emerged parties were trained in state-sponsored modern schools for becoming state servants, including military officers, civilian bureaucrats, teachers, and professionals. ${ }^{42}$ But contrary to the state's primary desire, members of the young elite took antistate positions by adopting radical ideologies, from Islamism to Marxism. As a result, a new political camp was opened in Kabul affecting Afghanistan's politics and the country's political development for decades to come. ${ }^{443}$ While the state remained incapable of regulating its relations with the social units of authority, now it had to deal with radicalism in Kabul too. This process pushed Afghanistan toward radical political collisions, coups, and civil war which, in turn, exacerbated the already fragile relations between the state and social units.

Unlike the Musahiban's state conservatism, the PDPA's approach to state-building was a social transformation policy based on a direct intervention in social affairs through the extension

\footnotetext{
${ }^{441}$ Barfield, Afghanistan, 211; M. Nazef Shahrani, "State Formation and Social Fragmentation in Afghanistan," in A. Banuazizi and M. Wiener (eds.), The State, Religion, and Ethnic Politics in Afghanistan, Iran, and Pakistan, 2374 (New York: Syracuse University Press 1986), 60.

${ }^{442}$ Barfield, Afghanistan, 210-11.

${ }^{443}$ Shahrani, "State Formation and Social Fragmentation in Afghanistan," 60-61.
} 
of the formal institutions into the informal social. ${ }^{44}$ This policy faced a violent reaction by traditional forces leading to civil war, external intervention, and eventually state collapse.

The PDPA was formed of two main factions, the Khalq which ruled from April 1978 to December 1979, and the Parcham which was in power from January 1980 to April 992. Although there were some differences in degrees of intensity in the two factions' policies of intervening in social affairs, direct intervention remained consistently their policy principle. Following a massive resistance to the Khalqi regime's radical agenda, Parchamis managed to soften the means of intervention in social affairs by adding methods of pacification, intermediation, and bribery to the primary policy. ${ }^{445}$ Thus, despite regime changes and the expansion of rebellion in the $1980 \mathrm{~s}$, the PDPA government continuously drew on direct penetration as its main policy. ${ }^{446}$ Evidence shows that the PDPA's social transformation policy during Parchamis was followed by methods of land distribution, the expansion of the "working class" and party membership in the cities, and the extension of party structure and peasantry cooperatives in the countryside, and ultimately through coercion. ${ }^{447}$ Hence, the term 'social transformation' is applicable as the main state-building policy of the PDPA, regardless of its changing nature over time.

The PDPA came to power through a coup d'état on April 27, 1978. Assassinating President Mohammad Daoud, the PDPA renamed Afghanistan the Democratic Republic of Afghanistan (DRA). The DRA implemented a social engineering agenda during its first 19 months of ruling which "ran counter to the deeply rooted Afghan tradition." 448 The Khalq faction planned, at first,

\footnotetext{
${ }^{444}$ Antonio Giustozzi, War, Politics, and Society in Afghanistan, 1978-1992 (Washington DC:

Georgetown University Press, 2000), 120; Bogdan Szajkowski (ed.), Documents in Communist Affairs 1980 (London and Basingstoke: The Macmillan Press LTS 1981), 172-74.

${ }^{445}$ Rubin, The Fragmentation of Afghanistan, 136, 142, 165-66.

${ }^{446}$ Giustozzi, War, Politics, and Society in Afghanistan, 15, 20-55, 95-99, 70-71.

${ }^{447}$ Giustozzi, War, Politics, and Society in Afghanistan, 15-55, 70-71, 95-99; Rubin, The Fragmentation of Afghanistan, 123.

${ }^{448}$ Underhill, Countering Global Terrorism and Insurgency, 40.
} 
to extend its authority in the rural traditional society through installing the ruling party's institutions in provinces, districts, and villages. ${ }^{449}$ The plan was to re-engineer Afghanistan's traditional social structure and political landscape by replacing its local units (qawm) with provincial, city, district and county level 'party committees. ${ }^{450}$ According to this plan, the party "secretaries" who were mostly state trained schoolteachers and army officers, with little or no connections to the community, would gradually replace the rural elite, khans and arbabs. ${ }^{451}$ In order to provide a legal basis to its social transformation agenda, the PDPA released a series of decrees concerning fundamental social issues, including land ownership, marriage prestations, loans, mortgages, tenancy, hospitality, and the like. "If implemented, these decrees would have transformed the Afghan rural society with a system of economically comparable nuclear families linked through market relations and tied directly to the state." ${ }^{252}$

The Khalqi reformation programs turned the countryside and traditional Afghanistan as a whole, against the already fragile state. By the summer of 1978, a revolt began in Nuristan province of eastern Afghanistan and quickly developed into a countrywide insurgency mainly led by the rural elite and the Pakistan-based Islamists who had fled Daoud's prosecution in the mid-1970s. By the expansion of the anti-Khalqi rebellion, some 80 percent of the country became out of effective government control. ${ }^{453}$ According to official data, by the beginning of 1980, the PDPA controlled only 5,500 of the country's estimated 35,500 villages." 454 This meant the government had lost the effective control of over 85 percent of Afghanistan's rural areas. The expansion of the

\footnotetext{
449 Antonio Giustozzi, Empires of Mud: War and Warlords in Afghanistan (London: Hurst \& Company, 2009), 3640.

${ }^{450}$ Szajkowski (ed.), Documents in Communist Affairs 1980.

${ }^{451}$ Rubin, The Fragmentation of Afghanistan, 18.

452 Ibid., 116.

${ }^{453}$ Nancy P. Newell \& Richard S Newell, The Struggle for Afghanistan (Ithaca, NY: Cornell University Press, 1981), 85; Underhill, Countering Global Terrorism and Insurgency, 40-41.

${ }^{454}$ Barfield, Afghanistan, 230-31; Giustozzi, War, Politics, and Society in Afghanistan, 1978-1992, 17.
} 
rebellion coincided with the factional disputes within the party. This resulted in the refragmentation of the PDPA into Khalq and Parcham factions. The severe political crisis exhausted the PDPA regime and forced the Soviets to invade Afghanistan in December 1978, in order to rescue the 'friendly government' from a total collapse. ${ }^{455}$

The Soviet invasion resulted in a transition of power in Kabul from the Khalqi to the Parchami faction of the PDPA. The new PDPA government designed a softer approach by bringing some minor shifts in tactics. One of the tactical changes was the creation of special state institutions such as the Ministry of Tribal Affairs to bribe and manipulate the tribal and religious elite in its overall strategy. ${ }^{456}$ From the early 1980 s, the state began a broad campaign of buying mullahs and local Islamic figures. From 1980 to 1986, for instance, the government claimed to have spent more than Afs3.3 billion or $\$ 80$ million, ${ }^{457}$ in support of Islam, including building and managing mosques, assisting the clergy, and financing religious education. ${ }^{458}$ This program expanded over time. By 1989 some 20,000 mullahs were receiving government salaries and coupons for food and commodities. $^{459}$ Moreover, while the land ceiling was imposed on the society, the PDPA government exempted religious figures, khans, and arbabs who supported the government and military officers from land ceilings. ${ }^{460}$

Parallel to its "soft policy," the state relied heavily on hard force to transform society through direct intervention and suppression. According to Amnesty International, 8,006 people were executed by sentence of the Special Revolutionary Court between 1980 and $1988 .{ }^{461}$ The

\footnotetext{
${ }^{455}$ Underhill, Countering Global Terrorism and Insurgency, 40.

456 The ministry was subsequently named as the Ministry of Nationalities and Tribes, and later as the Ministry of Tribal and Border Affairs.

${ }^{457}$ For exchange rate see Maxwell J. Fry, “A Monetary Approach to Afghanistan's Flexible Exchange Rate.” Journal of Money, Credit and Banking, 8(2), 1976, 219-225.

${ }^{458}$ Rubin, The Fragmentation of Afghanistan, 136.

${ }^{459}$ Ibid., 165-66.

${ }^{460}$ Rubin, The Fragmentation of Afghanistan, 142.

${ }^{461}$ Underhill, Countering Global Terrorism and Insurgency, 40.
} 
state's secret police, KhAD, had arrested 150,000 people mostly from Kabul city during the same time. ${ }^{462}$ In cities, the state relied on the secret police called Khadamat-e Aetla'at-e Dawlati or the State Intelligence Services (KHAD), and in the countryside it mainly relied on the army to suppress the armed mujahidin and rebel groups. Furthermore, the gendarmerie and the secret police were used to back the expansion of mushrooming party committees in state-controlled villages. Thus, the regime relied primarily on military and police techniques of coercion ${ }^{463}$ rather than drawing on politics of intermediation like the Musahiban. In the beginning, the PDPA's approach seemed relatively successful in extending the state institutions and installing its district and county-level party committees in some parts of the rural Afghanistan. But the state's direct intervention politics in traditional affairs and the Soviet invasion intensified the growing rebellion organized mainly around anti-Soviet Islamists and anti-state tribal leaders. The widening state-society gap led to the erosion of the state institutions at first in the countryside and subsequently in the cities. As a result, the state was defeated by the rebel and mujahidin forces in April 1992 which was highly divided along tribal, ethnolinguistic, and religious lines. The victorious anti-state jihadi and rebel groups with their 300,000 combatants ${ }^{464}$ disintegrated the state looting its resources and destructing its one-century-old institutions. As a result, the state entirely collapsed in the 1900s which drove the country into an anarchical state of "war of everyone against everyone."

\footnotetext{
${ }^{462}$ Rubin, The Fragmentation of Afghanistan, 137.

${ }^{463}$ Ibid., 123.

${ }^{464}$ Bhatia, Michael. "Armed Groups in Afghanistan." in Afghanistan, Arms and Conflict: Armed Groups, Disarmament and Security in a Post-War Society, edited by Michael Bhatia and Mark Sedra, 72-110. New York: Routledge, 2008.
} 


\section{Civil War and State Fragility}

With the defeat of the PDPA and the outbreak of civil war (1992-1996) among mujahidin and rebel groups in Kabul and beyond, the state entirely disintegrated. Although the mujahidin groups initially reached a temporary agreement to form an interim administration and provide for the election, the ethnic and sectarian divide and contradicting political agendas among them made any form of political cooperation impossible. The major source of the problem was the disagreement over the distribution of power between Burhanuddin Rabbani's Jamiat-i-Islami mainly led by Tajik combatants and Gulbuddin Hekmatyar's Hezb-i-Islami which was basically formed of Pashtun jihadis. The post-PDPA Islamic State, following a two-month interim government led by Sebghatulah Mujadidi, the leader of the National Salvation Front, became under the control of one party, Rabbani's Jamiat-e-Islami which was confronted with the reaction other jihadi and rebel parties, particularly Hekmatyar's Hezb-i-Islami. All internal, regional, and international efforts to stabilize Afghanistan and create a broad-based government failed due to many reasons among which two were decisive: the warring parties' totalitarian tendency for obtaining power ${ }^{465}$ and the regional powers' contradictory support of their favorite parties in Afghanistan.

In the early weeks of May 1992, Kabul turned into a battlefield of the victorious groups. Tajik and Uzbek paramilitary groups led by Ahmad Shah Massoud and Abdul Rashid Dostum controlled most of the city center and the northeastern quarter where many government buildings are located, while their Pashtun rivals, mostly led by Gulbuddin Hekmatyar, occupied the high ground and suburbs of south of the city. The Hazaras, commanded by Abdul Ali Mazari, controlled neighborhoods in the western quarter. There were many other smaller paramilitary groups camped behind one of the four major parties.

${ }^{465}$ Barfield, Afghanistan, 250. 
The battle for control of Kabul was a "microcosm" of the country's overall situation. ${ }^{466}$ As a result, paramilitary groups divided the country into five military zones: south and east were mainly controlled by Pashtun commanders, north and northeast were mainly divided between Tajik and Uzbek militias, the west was mostly controlled by Tajik commanders under Ismael Khan, and the central part of the country was dominated by Hazara militants. In some places, local commanders struggled for influence over limited tracts of territory, while in other parts they fought, switched side and fought again in a "bewildering array of alliance, betrayals and bloodshed" mainly over controlling territory, governmental establishments, and economic resources. ${ }^{467}$ The warring groups were unable to find any common agreement about what a future government would look like, let alone who should run it.

The situation of the country, in this period, can be well defined by Hobbes' state of nature. Central authority was extremely disintegrated and no authority was capable of "carrying out its end of the social contract." As a result, the Afghan state totally lost its sense of statehood and thus its legitimacy in the eyes of its citizens. The mujahidin's internal division was also exacerbated by external influence. Hekmatyar was openly supported by Pakistanis, Saudis, and Iranians, Rabbani and Masoud were supported by Indians, and Tajiks, Dostum received support from Uzbeks and Turks, and Mazari was supported by Iranians. Afghanistan, in this regard, became also a focal point of regional rivalries.

The emergence of the Taliban as another warring group in 1994 in Kandahar marked the beginning of a new phase of the conflict. The situation in the early 1990s had erupted into an ethnic-based civil war and by the emergence of the Taliban, the violence had spread throughout the country. The anarchic political and chaotic social environment had produced a political vacuum

\footnotetext{
466 Maley. The Afghanistan Wars, 173-174.

467 Ibid.
} 
in Afghanistan and a lack of central governance which a group such as the Taliban was willing to fill. Thus, the emergence of the Taliban was both a response to the internal chaos and a consequence of Pakistan's regional politics. Although the Taliban presented themselves as an Islamic solution to the problem of a state failure ${ }^{468}$ the group's campaign did not change the overall situation of Afghanistan.

When the Taliban captured Kabul in 1996, Afghanistan was one of the "seven most severely fragile states of the world" ${ }^{\prime 69}$ which lacked a legitimate central authority, a regular security apparatus, and regular service-providing governmental institutions. The Taliban neither had the capability nor a clear agenda to restore the collapsed state. During the Taliban's five years rule (1996-2001), the group was incapable of finding any political solution to the problem of Afghanistan. Accordingly, the Afghan state, during the Taliban regime, remained highly fragile in all three areas of legitimacy, authority, and capacity. State fragility, in this sense, provided a favorable condition for the emergence of al-Qaeda. As discussed in the previous chapter, al-Qaeda was the direct outcome of a number of causes at three levels of analysis. The relationship between those causes and the formation of al-Qaeda was magnified by lack of state legitimacy, poor authority, and lack of state capacity in Afghanistan under the Taliban. The rest of this chapter elaborates on the role of state fragility in Afghanistan in the emergence of al-Qaeda.

\section{State Fragility and the Emergence of al-Qaeda}

The Taliban emerged, primarily, as an insurgent group in the midst of Afghanistan's civil war, in 1994 in the southern province of Kandahar. The emergence of the Taliban, like all other warring groups in Afghanistan, had both internal and external causes. Internally, the group was the product

\footnotetext{
${ }^{468}$ Rubin, The Fragmentation of Afghanistan, xiii.

${ }^{469}$ Rotberg. "The New Nature of Nation-State Failure," 90.
} 
of the inter-mujahedeen groups' civil war that started in 1992. The war, as discussed, produced a political and security vacuum which the Taliban filled.

Externally, the Taliban's formation was the product of regional rivalries, particularly Pakistan's regional ambitions. Despite Pakistan's official denials of creating the Taliban, almost all publicly accessible documents and reliable scholarly work confirm creation, funding, and mobilization of the Taliban by Pakistan. ${ }^{470}$ Evidence shows Pakistan's "ISI field officers, Pakistani Frontier Corps, and regular Pakistani armed forces personnel" were directly involved in supporting the Taliban. ${ }^{411}$ Pakistan's main purpose of sponsoring the Taliban was to create a regime in Kabul which would be favorable to Islamabad and to "open an economic bloc extending as far as Central Asia. ${ }^{272}$ Another strong influence behind the Taliban's emergence and its development into a state structure was the Jamiat-i-Ulema-i-Islami, led by Maulana FazlurRahma, who was itself responsible for running many Deobandi madrassas in Pakistan and in 1993 became a coalition partner in the Pakistani government. ${ }^{473}$

\footnotetext{
${ }^{470}$ Goodson, Afghanistan's Endless War, 111; O. B. Jones, Pakistan: Eye of the Storm (New Haven and London: Yale University Press, 2003), 240; H. Paimani, Falling Terrorism and Rising Conflicts: The Afghan Contribution to Polarization and Confrontation in West and South Asia (Westport: Greenwood Press, 2003), 14; D. Byman, Deadly Connections: States That Sponsor Terrorism (Cambridge and New York: Cambridge University Press, 2005), 195; T. H. Johnson, "Financing Afghan Terrorism: Thugs, Drugs, and Creative Movement of Money, in J. K. Giraldo, and H. A. Trinkunas eds., Terrorism: Financing and State Responses, 93-114 (Stanford: Stanford University Press, 2007), p. 97; D. P. Forsythe, ed., Encyclopedia of Human Rights vol. 1 (New York: Oxford University, 2009), p. 2; R. A. Pape, Cutting the Fuse: The Explosion of Global Suicide Terrorism and How to Stop It (Chicago, London: University of Chicago Press, 2010), pp. 140-141; Ahmed Rashid, "Scourge of God: Strict Islamic Rules Imposed in Afghanistan by the Ruling Taliban are Plunging that Strife-Torn country Deeper into Ruin," Hongkong Press, August 7, 1997, pp. 23-24. (https://www.myheritage.com/research/record-90100-594474026/afghanistan-forumnew-york-afghanistan-news-bulletin-july-august?trp=\&trn=organic_google\&trl); Human Rights Watch, Pakistan 's Support of the Taliban (New York: Human Rights Watch, 2001) (https://www.hrw.org/reports/2001/afghan2/Afghan0701-02.htm); Mori DocID: 800277, "Secret, Noforn...;" From [Excised] to DIA, "[Excised], Pakistan Interservice Intelligence...;" From [Excised] to DIA, "IIR [Excised] Pakistan Involvement," p. 2.

${ }^{471}$ Mori DocID: 800277, "Secret, Noforn...;" From [Excised] to DIA, “[Excised], Pakistan Interservice Intelligence...;" From [Excised] to DIA, "IIR [Excised] Pakistan Involvement," p. 2.

${ }^{472}$ Ewans, Afghanistan: A New History, p. 201; Boase, Islam and Global Dialogue, p. 85.

${ }^{473}$ Martin Ewans, Afghanistan: A New History (London and New York: Routledge, 2002), p.186
} 
On the ground, the Taliban first emerged as a group of 30 madrassa students in a reaction to a local warlord who had abducted and repeatedly raped two teenage girls in Kandahar. In March 1994, the 30 Talibs/Taliban "attacked the warlord's camp, freed the girls and hung the commander from the barrel of a tank." ${ }^{474}$ Following the "heroic" event, the Taliban crossed the border into Pakistan where the number of the group increased to 200 in few months. A couple of months later, in October 1994, the Taliban, mobilized under Mullah Mohammad Omar's command, returned to Afghanistan and took initially the control of Spinbuldak district of Kandahar province from Hekmatyar's men. ${ }^{475}$ In next three months, the group captured of 12 of Afghanistan's then 31 provinces. A year later, in March 1996, the Taliban organized a gathering of some 1200 Islamic clerics from all around Afghanistan in Kandahar through which the Taliban's leader, Mullah Mohammad Omer, was entitled as the Amir al-Moumenin, the Commander of the Faithful. ${ }^{476}$ In the Taliban's ideology, Amir-al-Moumenin is a political leader who has a religiously legitimate authority over people living in a territory controlled by his followers. Obeying Amir-al-Moumenin was fardh (God's demand and must be practiced). Because the principal root of obeying the Amiral-Moumenin is the law of God, anyone who refused bayat (oath of allegiance) to Amir-alMoumenin "would be called a rebel according to sharia, it would be a fardh to execute him/her." The gathering took place from March 20 to April 4, 1996. It is broadly cited that at the end of the gathering, Mullah Omer renamed Afghanistan 'the Islamic Emirate of Afghanistan' (IEA). ${ }^{478}$ However, a review of the Sharia, the Taliban's official newspaper, shows that the name IEA was

\footnotetext{
${ }^{474}$ Rashid, Taliban, p. 25.

${ }^{475}$ Neamatollah Nojumi, The Rise of the Taliban in Afghanistan: Mass Mobilization, Civil War, and the Future of the Region (New York: Palgrave, 2002), p. 118.

${ }^{476}$ Nojumi, The Rise of the Taliban in Afghanistan, p. 154; Thomas Barfield, Afghanistan: A Cultural and Political History (New Jersey: Princeton University Press), p. 261.

${ }^{477}$ Nojumi, The Rise of the Taliban in Afghanistan, p. 154; Barfield, Afghanistan, p. 261.

${ }^{478}$ See for example, Akmal Davi, "The Taliban Published Mullah Omer's Biography," The Voice of America, April 5, 2015 (http://www.darivoa.com/a/taliban-mullah-omar-biography/2707473.html).
} 
used first on October 29, 1997, a year after the group captured Kabul through an official order attributed to Mullah Omer:

“In accordance with his Excellency, Amir al - Moumenin's guidance of October 13, 1997, from this time on the Islamic State of Afghanistan will be named as the Islamic Emirate of Afghanistan. All organizations and governmental institutions and the Islamic Emirate of Afghanistan's citizens should do all their efforts to prevail/expand this letter." ${ }^{479}$

According to the Taliban's official documents, including Sharia, before the publication of the above order, the Taliban called Afghanistan 'the Islamic State of Afghanistan' (ISA). ${ }^{480}$ ISA was the title Mujahidin groups put on Afghanistan after they defeated the PDPA's Republic of Afghanistan. The name IEA was justified by Islamic reasons and with reference to religious texts. The justification of renaming Afghanistan as IEA also appeared in the Sharia:

"The famous Alim/cleric and the principal of Rahat Abad Madrasa, Mawlana Rahat Gul, welcomed his Excellency Amir al-Mouminin's replacement of the Islamic State of Afghanistan with the Islamic Emirate of Afghanistan. He characterized the Islamic Emirate as the extension of the Islamic Caliphate. He stated that the term state could be used both for Islamic and non-Islamic rule. But the term Emirate is specifically attributed to Islamic authority. According to him, the current government of Afghanistan is not a state, but an Emirate..."481

\footnotetext{
${ }^{479}$ Sharia 2(43), October 29, 1997: 1.

${ }^{480}$ see for instance Saria 1(48), December 2, 1996, pp.1, 2; Sharia 2(1), January 2 1997, p. 1; Sharia 2(3), January 16, 1997, p. 1; Sharia 2(5) January 31, 1997, p. 1; Sharia 2(7), February 2, 1997, p. 1; Sharia 2(12), March 26, 1997, p. 1; Sharia, 2(38), September 24, 1997, pp. 1, 2.

${ }^{481}$ Sharia, 2(44), November 5 1997, pp. 1, 4.
} 
Following the capture of Kabul, the Taliban produced a two-track government, a leadership council (the Supreme Council) in Kandahar and a Council of Ministers (the Kabul Council) in Kabul with Mullah Omer himself acting as the head of the state. ${ }^{482}$ The Supreme Council had six members and was directly led by Mullah Omer, and the Council of Ministers worked under the direct supervision of the Supreme Council. The Supreme Council had two subsidiary branches, an Ulema Shura or a Council of Clerics and the Military Council which consulted respectively the country's religious and military affairs and worked directly under Mullah Omer's command.

Besides the Supreme Council's political and moral supremacy, all administrative and executive affairs were legally assigned to the Council of Ministers led by an individual called Rayees al-Wazara, the Chairman of the Council of Minister. ${ }^{483}$ The rights and duties of the Council of Ministers were specified in a legislation entitled the Council of Ministers' Act which was published in the Official Gazette on May 2, 2001. According to this act, the Council of Ministers of the IEA was described as "the highest executive and administrative bureau of the government" and considered responsible for enforcing Sharia, leading the IEA's internal and foreign policies, and leading the country's defensive and army affairs. ${ }^{484}$ The Council was also considered responsible for organizing the country's social, economic, cultural, and administrative affairs in Kabul and the provinces. ${ }^{485}$ If the Council of Ministers was given all authorities described in the Act, then the Supreme Council would have turned into a ceremonial body of the state. Nonetheless, evidence shows that the Supreme Council never stopped intervening in all major and minor affairs of the country from 'war-making' to 'state-making' to 'decision-making' and to micromanaging

\footnotetext{
${ }^{482}$ Barnett R. Rubin, The Fragmentation of Afghanistan (New Haven: Yale University Press. 2002), p. xv.

${ }^{483}$ Sharia 5(9), February 2, 2000, p. 1.

${ }^{484}$ The Council of Ministers' Act, Official Gazette, No. 797, May 2, 2001, article 3.

${ }^{485}$ Council of Ministers' Act, Official Gazette, No. 797, May 2, 2001, articles 1, 2, and 6.
} 
the state's affairs on all internal and external issues. ${ }^{486}$ Thus, the act put the Council of Ministers on the top of the executive and administrative affairs of the IEA but, in practice, the Supreme Council with an Amir al-Moumenin at its head remained as the most influential body of the IEA.

The IEA's two-track state system of governance was based on a 'war-making' strategy which was designed in a way to capture, dominate, and lead Afghanistan militarily. But the Taliban, in general, failed to generate a functioning regular state. The group indicated severe weakness in all three areas of statehood. It lacked a broad-based legitimate governing system acceptable internally and officially recognized internationally, it did not have authority (in terms of enjoying sufficient military and security capability to end the war, enforce the law, and secure the country), and it lacked the capacity to collect taxes and provide the citizens with the very basic services. State fragility, in this sense, produced a condition under which motivated Islamist militants under bin Laden's command infiltrated into Afghanistan and organized the 'world Islamic front.' So, poor state legitimacy, lack authority, and capacity were the conditions which magnified the causal effects of the formation of al-Qaeda in Afghanistan in 1996, and its official launch in 1998.

\section{Poor Legitimacy}

Poor internal and lack of external legitimacy was the main characteristic of the IEA. Internally, the IEA lacked a broad-based popular support and externally it was not officially recognized by the international community.

\footnotetext{
${ }^{486}$ E.g., Sharia, 3(5), August 16, 1998, pp. 1, 4; Sharia 6(18), March 11, 2001, pp. 1, 4; Sharia 3(57), 23 August, 1998: 1; Sharia 5(68), September 19, 2000, pp. 1, 4. Sharia, 6(50), July 11, 2001, p. 1.
} 
Internally, considering Weber's articulation of the three basic sources of legitimacy (i.e. traditional, charismatic and rational-legal), the IEA relied on a traditional source. ${ }^{487}$ The IEA legitimated its authority, in particular, on the basis of Islam. Although the IEA's behavior was also based on the tradition of authority in Afghanistan according to which Pashtuns dominantly ruled the country, Islam was the primary source of legitimacy which the Taliban officially and publicly defined as its principal source of authority. Islamic legitimation of the IEA is apparent in its main official documents and declaration published in the Sharia:

“The Islamic Movement of the Taliban is a revolutionary and religious movement... Of the Islamic Movement of the Taliban which is sprouted of the Islamic madrasas... one can only expect the creation of a Sharia-based Islamic regime.' 'Our platform is an Islamic one. Within the framework of the holy religion of Islam, we will follow this platform... From its outset, our Islamic movement has promised to the Mujahid nation of Afghanistan of establishing an Islamic regime, enforcing Sharia...' 'There is no doubt that the IEA's all decisions are in accordance with the Islamic texts.' The Taliban's uprising is confirmed by a large number of Islamic scholars, the IEA enforces Sharia completely... and the majority of the IEA's leadership and officials are Sunni individuals and clerics' [the majority Islamic sect in Afghanistan]." ${ }^{488}$

The Taliban leadership emphasized that the IEA would enforce Sharia in Afghanistan by any means possible. As Mawlawi Wakil Ahmad Motawakkil, then the spokesman of the IEA,

\footnotetext{
${ }^{487}$ Weber, The Vocation Lectures, p. 34; Max Weber, "The Three Types of Legitimate Rule" Translated by H Gerth, Berkeley Publications in Society and Institutions, 4(1), 1958: pp. 1-11; Underhill, Countering Global Terrorism and Insurgency, 62; Thomas H. Johnson, and M. Chris Mason, "Democracy in Afghanistan is Wishful Thinking,"

Christian Science Monitor, 2009 (http://www.csmonitor.com/Commentary/Opinion/2009/0820/p09s01-coop.html).

${ }^{488}$ Sharia 1(39) September 28, 1996, p. 1; Sharia 1(1), January 1, 1995, pp. 1, 2; Sharia, 6(20), March 18, 2001: pp.

1, 2; Sharia 5(58), August 15, 2000: pp. 1, 2.
} 
highlighted in an April 1998 statement that "for enforcing Islamic principles, the IEA will not have any tolerance." ${ }^{489}$ Thus, the IEA used Islam as a restrictive political source of legitimation to forbid any political activity opposed to the Taliban. The regime propagated that, with a pure Islamic regime in place, there is no need for any alternative political mechanisms such as a modern party system or a traditional tribal system. ${ }^{490}$ In an official statement published on the Sharia, for instance, Mullah Omer emphasized that "with the Taliban being in power there is no need for any kind of "elders' grand council," Loya Jirga, or any other "third party." "491 The IEA also expressed that, with Islam being the legitimizing source of governance in Afghanistan, there is a need to draw on ethnic, tribal, or sectarian politics. ${ }^{492}$ In two separate statements, Mullah Omer, and the IEA's Minister of Information and Culture, Qudratullah Jamal, highlighted the IEA's sole reliance on Islam:

"The Taliban movement is an Islamic movement, and the officials and members of this movement never think of ethnic and sectarian basis. In accordance with the Islamic Sharia, the IEA respects all ethnic groups." ${ }^{\prime 493}$ 'It is a recognized reality that the IEA's policies and platform are in accordance with Islam in which there is no such thing as majority and minority." ${ }^{, 494}$

Despite the IEA's constant emphasis on Islam as its main source of legitimation, there is numerous empirical data and evidence that indicates the significance of ethnic-based politics in the IEA's behavior and policies. Among others, the IEA's internal rival, Jamyat-e-Islami repeatedly claimed that "Islam is a cover for the Taliban's ethnic politics in Afghanistan." ${ }^{495}$ In fact, the IEA was

\footnotetext{
${ }^{489}$ Sharia 3(21), April 19, 1998: p. 1.

${ }^{490}$ Ibid., 5(57), August 12, 2000: p. 1, 2.

${ }^{491}$ Ibid., 3(48), July 22, 1998: p. 1.

${ }^{492}$ Ibid., 3(55), 16 August 1998: p. 1.

${ }^{493}$ Ibid., 3(5), August 16, 1998: pp. 1, 4.

${ }^{494}$ Ibid., 5(91), December 9, 2000: p. 4.

${ }^{495}$ Payam-e-Mujahid 4(9), March 18, 2000: p. 4.
} 
entirely dominated by a specific ethnic group. The IEA's both governing councils, the Supreme Council and the Council of Ministers were exclusively dominated by Pashtun clerics and madrassa students/Talibs. For example, of the six original members of the Supreme Council, five were Pashtuns and only one, Maulvi Sayed Ghiasuddin, was a Tajik from Badakhshan. Likewise, out of 17 members of the Council of Ministers in 1998, only two were non-Pashtuns. ${ }^{496}$ Furthermore, the IEA appointed provincial governors and administrators of districts, cities, and towns from the center, Kandahar or Kabul, depending on the importance of the position. These administrators, particularly the governors of major provinces and districts, were dominantly Pashtuns. In Kabul, Herat, and Mazar, three major provinces with no Pashtun majority, the Taliban's representatives such as governors, mayors, police chiefs and other senior administrators were invariably Pashtuns who either did not speak Farsi, the lingua franca of these cities, or spook it poorly. ${ }^{497}$

The IEA used a specific interpretation of Islamic Sharia, Deobandism, which is the subcontinental branch of the Islamist ideology. Deobandism follows a Salafi interpretation of Islam and like all Islamist schools seeks to "emulate the life and times of the Prophet" and "rejects ijtihad or the use of reason to create innovations in sharia in response to new conditions." ${ }^{\text {498 }}$ The Deobandi philosophy was founded in 1867 at the Dar ul-Ulum madrassa in Deoband, India. Deobandi madrassas expanded across South Asia, and they were officially supported in Pakistan when President Mohammed Zia-ul-Haq assumed control of the Pakistani government in 1977. ${ }^{499}$ The Taliban members were students at these madrassas that were broadly controlled by Pakistani Islamist parties, particularly, the Jamaat Islami Pakistan (JIP), led by Qazi Hussein Ahmad, and

\footnotetext{
${ }^{496}$ Rashid, Taliban, pp. 98, 222-25; Angelo Rasanayagam, Afghanistan: A Modern History (London and New York: I. B. Tauris, 2005), p. 192.

${ }^{497}$ Rashid, Taliban, 98-99.

${ }^{498}$ B. D. Metcalf, Islamic Revival in British India: Deobandi, 1860-1900 (Princeton: Princeton University Press, 1982); Rubin, The Fragmentation of Afghanistan, p. xv; Seth G. Jones, "The Rise of Afghanistan's Insurgency: State Failure and Jihad" International Security 32(4), 2008, pp. 72.

${ }^{499}$ Jones, "The Rise of Afghanistan's Insurgency," p. 72.
} 
Jamaat-e-Ulema-e-Islami Pakistan (JUIP) led by Maulana Fazl ul-Rahman. ${ }^{500}$ The IEA's Deobandi interpretation of sharia is crystalized in the IEA's publications, regulations, policies and procedures. The IEA enforced numerous law decrees in accordance with Deobandism. To make sure that these decrees were implemented in Afghanistan, the IEA established a religious police called Amr-e-Bil Marouf Wa Nahi Anil Munker or The General Department for the Preservation of Virtues and the Elimination of Vice. ${ }^{501}$ The organization had "thousands of informers" in all levels of the state and society who monitored people's behavior and Western aid agencies' activities. ${ }^{502}$ Most of these informers were teenagers and recent graduates of the Pakistani madrassas. Among other activities, these informers patrolled the streets, making sure that the people go to the mosque at the time of daily prayers, women are covered, and men have not shaved their beard..$^{503}$

All characteristics of Deobandism were found in exaggerated form among the Taliban which were fundamentally alien in Afghanistan. ${ }^{504}$ Although Afghanistan is an Islamic country and Islam has functioned as a source of legitimacy and jurisprudence for centuries, the Taliban's Deobandism and its coercive approach to law enforcement was broadly unwelcomed in the country. Except for individuals who joined the Taliban, the rest of the population, even the rural religious communities, were not interested in following the Taliban's Islamism. The IEA was also not recognized as a legitimate authority by all rival parties that also considered themselves as Islamic organizations. The Payam-e-Mujahid, for example, questioned the main legitimizing source of the IEA ${ }^{505}$ An Islamic fatwa published in this paper described the Taliban as a rebellion

\footnotetext{
${ }^{500}$ Nojumi, The Rise of the Taliban in Afghanistan, 119.

${ }^{501}$ Ibid., 154.

502 Rashid, "Scourge of God," 52; Nojumi The Rise of the Taliban in Afghanistan, 154.

${ }^{503}$ Nojumi, The Rise of the Taliban in Afghanistan, 154.

${ }^{504}$ Metcalf, Islamic Revival in British India; Rashid, Taliban; Rubin, The Fragmentation of Afghanistan, p. xv.

505 Payam Mujahin, 2(26-27-28-29), 30 August; 4, 11, 13 September 1997.
} 
group that disobeys a religiously legitimate government, the Islamic State of Afghanistan, led by Burhanuddin Rabbani: “On the basis of Sharia, Rabbani's government has not lost its legitimacy. Therefore, disobedience of this government is a subject to execution."506 While Islam has been a generally accepted source of political legitimation in Afghanistan, this statement indicates a high degree of disagreement and contradiction in the interpretation and usage of this source.

In addition to its poor internal legitimacy, the IEA lacked external legitimacy in the sense that it was not officially recognized by the international community as the sole source of authority in Afghanistan. In many international organizations, including the UN, Rabbani's ISA represented Afghanistan. In some countries, such as the United States, the Afghanistan diplomatic mission was suspended but consulate duties, despite the IEA's constant complaints, were delivered by ISA representatives. ${ }^{507}$ Moreover, the Deputy Foreign Minister of the ISA, Dr. Abdullah, attended the UN General Assembly in 1997 as the official representative of Afghanistan, and Rabbani represented Afghanistan at the annual conference of the Non-Allied countries in South Africa in September $1998 .{ }^{508}$ The international community's behavior towards the IEA was apparently influenced by three factors: the violation of women and human rights by the IEA, the Taliban's association with al-Qaeda, and the IEA's approach to resolving Afghanistan's problem by military means alone. The IEA refused all those accusations. ${ }^{509}$

Only three countries, Pakistan, Saudi Arabia and the United Arab Emirates, extended official recognition of the IEA and the latter two soon downgraded it. ${ }^{510}$ From its establishment

\footnotetext{
${ }^{506}$ Payam Mujahin 2(5) April 3, 1997, p. 1.

${ }^{507}$ See for example, Sharia 3(55), August 16, 1998, p. 1; Sharia, 3(22), April 22, 1998, pp. 1, 2; Payam-e-Mujahid, 2(25), August 27, 1997, p. 6; Payam-e-Mujahid, 2(25), August 27, 1997, p. 6.

508 Payam-e-Mujahid, 2(24), September 3, 1998; Payam-e-Mujahin 2(31-32), September 25 \& October 2, 1997 ; Payam-e-Mujahid 2(12), May 23, 1998, p. 1.

${ }^{509}$ Sharia, 5(89) December 2, 2000: 1, 4); Sharia 5(26), April 9, 2000: 4). Sharia 5(54), August 1, 2000: 1, 4); (Sharia 5(9), February 2, 2000: 1, 2); Khelaphat, July-August 2000, pp. 54-56; Khelaphat, May-June 2001, pp. 13, 34 , 33-34.

${ }^{510}$ Barfield, Afghanistan, 264.
} 
in 1996 until its disintegration in 2001, the IEA massively invested in diplomatic activities and propaganda to achieve international recognition. Following the Taliban's capture of Mazar-eSharif, the capital of the ISA, the Sharia questioned the UN's disregarding of the IEA's continuous request for an official international recognition:

"Will still the UN seek excuse [in recognizing IEA as the legitimate authority in Afghanistan]? Will it still propagate against the IEA? Will it create a Capital for Rabbani overseas?"511

A number of subsequent editorials of the Sharia blamed the UN for disregarding and ignoring the IEA's achievements in stabilizing the country and establishing a central authority:

"It has been years since Rabbani's regime is toppled. But Afghanistan's seat in the $\mathrm{UN}$ is still represented by the toppled regime... as long as Afghanistan's seat is dominated by Rabbani, his regime will claim legitimacy and receive weapons and military support from abroad... Despite its claim of supporting the peace process in Afghanistan, the UN officially recognizes an illegitimate regime and gives Afghanistan's seat in the United Nations to [the toppled regime]. ${ }^{512}$

Moreover, in diplomatic meetings and interactions between the Taliban and western officials, the main issue the former brought to the table was the official recognition of the IEA.${ }^{513}$ For example, following a visit to the United States in September 2000, in an interview with the Voice of America, the IEA's Deputy Foreign Minister, Mawlawi Abdurrahman Zahid, stated the purpose of his visit conveying a 'realistic picture of developments' in Afghanistan, in order to convince the international community to officially recognize the IEA:

\footnotetext{
${ }^{511}$ Sharia 3(55), August 16, 1998, p. 1.

512 Ibid., 1, 2.

${ }^{513}$ Sharia, 5(9), February 2, 200, pp. 1, 2; Sharia 5(31), April 30, 2000, pp. 1, 2; Sharia 5(43), June 25, 2000 , p. 1.
} 
"The international community should not disregard the official recognition of the IEA. The IEA has provided all conditions necessary for the formal recognition. The international community should not ignore the fact..."514

However, following a subsequent visit to the US, another IEA diplomat, Mullah Abdul Hakim Mujahid, pessimistically expressed that their request for recognition was intensively influenced by the case of bin Laden's presence in Afghanistan:

"During the meeting, their [the Americans'] concentration was on Osama bin Laden. We said... we are working on the fourth statement on bin Laden... But the point is that the American government has launched a massive propaganda exaggerating the case of bin Laden." ${ }^{515}$

Accordingly, neither the US nor other western countries showed any public intention in recognizing the IEA as a sovereign reality in Afghanistan until it was toppled in December 2001.

In addition to its failure in acquiring the international recognition, the IEA also remained isolated in the region. The Taliban's movement had no friend in the region, except Pakistan. Iran cut its relationship with the IEA due to the Taliban's anti-Shiite campaign. Central Asian states were frightened of the spread of the Taliban's Islamism into the region. Likewise, Russia was concerned with the IEA's fundamentalist version of Islam and reinforced its hostility to the Taliban when the IEA granted separatist Chechens full diplomatic recognition in $2000 .{ }^{516}$ The Saudis recalled their diplomatic staff from Kabul in 1998 after the Taliban refused their request to expel a Saudi citizen, bin Laden. Moreover, India was against the Taliban because of the group's proPakistani strategy.

\footnotetext{
${ }^{514}$ Ibid., 5(68), September 19, 2000, pp. 1, 4.

515 Ibid., 5(12), February 11, 2001, p. 1, 4.

${ }^{516}$ Ibid., 5(38), May 24, 2000, p. 1; Ibid., 5(6), January 23, 2000, p. 1.
} 
Beyond the region, the United States' post-Cold War disengagement policy in Afghanistan developed into hostility and direct engagement in the wake of the al-Qaeda attacks in 1998 on two US embassies in East Africa that began with a cruise missile strike against an al-Qaeda training camp in Afghanistan and continued with political and economic sanctions on Taliban. ${ }^{517}$ Moreover, the Buddhist states, including Japan which was providing Afghanistan with hundreds of millions of dollars in humanitarian aid, condemned the IEA's policy after the Taliban blew up the Bamiyan Buddhas in March 2001. ${ }^{518}$

The IEA's lack of internal and external legitimacy contributed to the emergence of alQaeda in Afghanistan. In the internal context, bin Laden and his inner circle significantly benefited from the Taliban's lack of a broad-based legitimacy and its reliance on Islamism as the main source of legitimacy. The Taliban's source of legitimacy, Islamism, provided a shared ideology and a 'brotherhood' between the Taliban and the Arab jihadis. Therefore, al-Qaeda's formation in Afghanistan was ideologically justifiable for the Taliban. The Taliban's extremist ideology is explained by Mullah Omar's empathy for Osama bin Laden and other al-Qaida leaders. ${ }^{519}$ At the end of a 1997 meeting between bin Laden and Mullah Omar on bin Laden's jihadi activities in Afghanistan, for instance, Omar told bin Laden "you are a Mujahid. This is your country and you are welcome to do whatever you like." 520

Moreover, most of the Taliban members were tribal Pashtuns who knew little of the wider Afghanistan. Legitimate leadership, and therefore legitimate governance to the Taliban eyes were the ones that had to fit into their tribal ones that were based on religious traditionalism and tribal ethos. Thus, to the Talib fighters, the government had to follow the sharia and be led by individuals

\footnotetext{
${ }^{517}$ Barfield, Afghanistan, 265-66.

518 Ibid., 265-66.

519 Jones, "The Rise of Afghanistan's Insurgency," 28.

${ }^{520}$ Gerges, The Rise and Fall of al-Qaeda, 62-63.
} 
who acquired both religious prestige, tribal loyalties, and military bravery. The Taliban's Islamism, traditionalism, and militarism produced a sense of transnational brotherhood, hospitality and heroism, simultaneously. On the basis of these principles, the IEA considered itself obliged to provide hospitality to a Muslim guest, and defend him against external forces. The IEA's friendly and hospitable behavior allowed bin Laden to expand its camps and jihadi activities throughout Afghanistan without any obstacle. Finally, since the IEA did not represent the people it ruled, in terms of not being democratically elected, and was not externally recognized, it was not accountable to both its citizens and the international community concerning activities taking place in its territory. The IEA's lack of representation and accountability, in this sense, greatly favored the formation and expansion of al-Qaeda in Afghanistan. Thus, lack of state legitimacy in Afghanistan secured al-Qaeda's initial camp-building and activities from any domestic or international inquiry. Any international inquiry could be simply ignored, and questions by the citizens could result in the person's interrogation and even physical elimination. Al-Qaeda's formation significantly benefited from those conditions.

\section{Poor Authority}

The Islamic Emirate of Afghanistan, unlike traditional authoritarian regimes that lack in legitimacy but enjoy authority, neither had the capability of claiming a monopoly on the use of force in Afghanistan nor was it capable of providing a secure environment to its citizens. As Weber (1919) conceptualized, the sovereign state, in order to lay claim to the monopoly of physical violence within a particular territory, should possess a sufficient physical force and use it legitimately. ${ }^{521}$ The 'physical force,' according to Tilly (1985), is a modern army which makes state-building

${ }^{521}$ Weber, The Vocation Lectures, p. 33. 
through the elimination/neutralization of the state's internal and external enemies possible. ${ }^{522}$ In other words, making a regular state requires a sufficient war-making apparatus, which is a regular army in the modern era. ${ }^{523}$ The IEA did not acquire sufficient force to eliminate its internal rival militarily and lacked the capability to secure its territory and citizens. ${ }^{524}$ Militarily, the IEA was engaged in an unending armed combat with its internal rival but lacked a sufficient force to eliminate it entirely. In other words, the IEA concentrated massively on "war-making" with the purpose of "state-making" but it never enjoyed a sufficient war machine to eliminate its rival and acquire the means of building a state that could provide protection and welfare to its clients. Instead, it was largely dependent on military support by Arab jihadis. Lack of authority and the IEA's dependence on foreign military support was another favorable condition for the emergence of al-Qaeda.

The IEA's military force was organized as an insurgent force more similar to a traditional tribal militia force, a Lashkar, rather than a regular army which is able to respond to internal threats, control borders and provide a governed and secure space to the population living in the country. ${ }^{525}$ Therefore, the IEA's military, security and law enforcement forces, together, were not capable of producing durable instruments of control and surveillance for providing security and protection, on the one hand, and controlling the state's territory and borders, on the other. ${ }^{526}$ The IEA itself admitted officially the lack of a regular army in Afghanistan and highlighted the need

\footnotetext{
522 Tilly, "War Making and State Making as Organized Crime," pp. 170-181.

${ }^{523}$ Ibid., 181; Charles Tilly, Coercion, Capital, and European States, AD 990-1990 (Cambridge: Basil Blackwell, 1990), pp. 17-20.

${ }^{524}$ Tilly, "War Making and State Making as Organized Crime," p. 181.

${ }^{525}$ Rashid, Taliban, p.100. For the IEA's security forces incapability in ending the war through the elimination of its rival forces, see Sharia 3(19), April 1, 1998: 1; Sharia 3(53), August 9, 1998; Sharia 3(54), August 12, 1998; Sharia 3(55), August 16, 1998:1; Sharia 3(55), 16 August 1998:1; Sharia 3(58), August 26, 1998: 1; Sharia 4(56) August 4, 1999: 1). And Payam-e-Mujahid 3(31), October 21, 2000; Payam-e-Mujahid 3(33), November 4, 2000; Payam-eMujahid 4(16) July 6, 2000; Payame-e-Mujahid 4(47) February 8, 2001; Payam-e-Mujahid 5(12), June 7, 2001, p. 2; Payam-e-Mujahid 5(25), September 6, 2001).

${ }^{526}$ Tilly, "War Making and State Making as Organized Crime," p. 181.
} 
to organize its military force as a "national Islamic army." A Sharia editorial in February 1998 states:

"Following the defeat of the Communist regime and the establishment of an Islamic administration and due to the jihadi parties' lack of a united administration and program, Afghanistan's powerful army was looted by militiamen... its logistical infrastructure was looted and its modern and sophisticated machinery was destroyed... Considering the IEA's armed forces victories, and with regard to our time's need [of a regular army] the IEA has started the rebuilding of the "national Islamic army'... The army is the soul of a nation... [In order to build an army that could defend Afghanistan] first, we have to create a sound [military] base formed of righteous and faithful officers and individuals." $" 527$

In order to show the IEA's concentration on rebuilding the aforementioned army, the Sharia opened a new page on March 4, 1998, entitled Urdu, the Army, which covered the Taliban's military progresses, its efforts in rebuilding the army's infrastructure and its technical and logistical bases. ${ }^{528}$ Nevertheless, neither the $U r d u$ page in the Sharia nor the Urdu, a special magazine published by the IEA's Ministry of National Defense, characterized what the 'national Islamic Army" would look like and how would it function. The Urdu highlighted only the Islamic army's ultimate goal as "the stabilization of Afghanistan through the enforcement of Sharia." ${ }^{2} 29$ Despite the IEA's earlier statements on its lack of a regular army, in the last months of its rule over Afghanistan, the Taliban leadership started highlighting the military, and law enforcement progresses and achievements. At this time al-Qaeda had already emerged and bin Laden was

\footnotetext{
${ }^{527}$ Sharia, 3(6), February 15, 1998, pp. 1, 2.

${ }_{528}$ Ibid., 3(11), March 5, 1998, p. 4 - subsequent issues.

${ }^{529}$ See Urdu 1, 1997, p. 2; Urdu 2, 2001.
} 
wanted by the United States and Saudi Arabia. In a statement in February 2001, the minister of culture and information of IEA, Mawlawi Qudratullah Jamal, claimed that the IEA controlled over the 90 percent of Afghanistan's territory:

Under a united Islamic regime, the IEA serves the people and provide them job opportunities in a secure and peaceful environment. Therefore, there is no more reason [for the international community] to disregard the IEA's official recognition." 530

The statement is broadly referenced as a proof of the IEA's military expansion in early 2000s. Nonetheless, evidence shows that IEA control of territory was not stable. The IEA did not have a regular army formed of its nationals, exclusively, and lacked the capability to control territory, constantly. The IEA's force significantly relied on Arabs and Pakistani combatants and military support, ${ }^{531}$ and could not steadily maintain the frontline areas. In addition to a lack of sufficient armed and security forces, the IEA's complex paramilitary structure and leadership was a major source of the problem. The IEA's armed forces' tactical decisions, including the provision of money, fuel, food, transport, weapons and ammunition for combatant units were mainly made by the Supreme Council's Military wing, based in Kandahar. A few months before its complete disintegration through the Operation Enduring Freedom, the IEA published the Council of the Ministers' Act in May 2001, according to which the Ministry of National Defense, based in Kabul, was described as an organization on top of the IEA's armed forces. ${ }^{532}$ But despite this legal statement, the IEA's armed forces remained under the Military Council's direct command. Apart

\footnotetext{
${ }^{530}$ Sharia 6(11), February 7, 2001: 1.

${ }^{531}$ Rashid, Taliban, p. 194; Mohamed Mahmoud Ould Mohamedou, Understanding al-Qaeda: the Transformation of War (London: Pluto Press), p. 49; Ould Mohamedou, Understanding al-Qaeda, 49; Peter Tomsen, The Wars of Afghanistan: Messianic Terrorism, Tribal Conflicts, and the Failures of Great Powers (New York: PublicAffairs, 2011), p. 322; Ahmed Rashid, "Pakistan and the Taliban." In William Maley ed., Fundamentalism Reborn? Afghanistan and the Taliban (New York: New York University Press, 1998), pp. 72-88.

532 The Council of Ministers' Act, Official Gazette, No. 797, May 2, 2001.
} 
from general strategies and key appointments and the allocation of funds for offensives that were decided directly by Mullah Omar, the Military Council consulted and determined all other major military decisions and activities in Afghanistan. ${ }^{533}$ This method created numerous overlaps on decision-making which in turn had made the development of a uniform military and security system almost impossible.

The overlap and its outcome were evident in the IEA's armed forces' structure and operations. Under the Military Council's guidance and supervision, individual commanders were responsible for recruiting men, paying them and looking after their needs in the field. The individual commanders directed their affiliated combatant units into the battlefields and took care of them as tribally loyal military units. There was no regular military structure with a hierarchy of officers and commanders, while unit commanders were being shifted around. ${ }^{534}$ Resources were assigned to these commanders directly from the Military Council, rather than the Ministry of National Defense. ${ }^{535}$ Due to its poorly equipped and trained armed force, its unsophisticated organizational structure, and its lack of a meaningful hierarchy, the IEA's armed forces resembled more a local insurgency or a traditional tribal militia force than a regular army.

Despite these shortcoming, the IEA claimed its armed forces acquired momentum in capturing and controlling territory. ${ }^{536}$ However, the evidence rejects such a capacity and shows the IEA's control over territory was unstable, particularly in frontline areas. The continuation of the war and the parties' unsteady control of land in northern and central parts of Afghanistan is broadly

\footnotetext{
${ }^{533}$ Rashi, Taliban, 99-100.

534 Ibid., 99.

535 Ibid., 100.

536 Sharia 3(19), April 1, 1998: 1; Sharia 3(53), August 9, 1998; Sharia 3(54), August 12, 1998; Sharia 3(55), August 16, 1998:1; Sharia 3(55), 16 August 1998:1; Sharia 3(58), August 26, 1998: 1; Sharia 4(56) August 4, 1999: 1; Sharia 6(11), February 7, 2001, p. 1.
} 
reported in the Sharia itself. ${ }^{537}$ And Payam-e-Mujahid shows that there was no absolute victory for anyone, with either side of the war having the capability of quickly preparing itself for new attacks following every defeat. ${ }^{538}$

The IEA's security and military weakness made it heavily dependent on foreign fighters and the military support it received from Pakistan and the Arab jihadis. Between 1994 and 1999 over 80,000 Pakistanis were trained and fought in Afghanistan. ${ }^{539}$ According to a finding, the NA captured hundreds of Pakistani soldiers during the war in northern Afghanistan. For example, a UN Security Council special envoy traveled to Afghanistan in July 1997 to investigate Pakistan's intervention in Afghanistan affairs. The Envoy observed more than 400 Pakistani citizens captured in Faryab, Balkh and Panjshir provinces by the NA. ${ }^{540}$ Pakistan was not the only country whose nationals joined and supported militarily the Taliban. Thousands of Arab, African, and East Asian and Central Asian Muslim jihadis fought for the Taliban. ${ }^{541}$ Most of those fighters were organized, equipped and trained by al-Qaeda. Integration of the 055 Brigade of al-Qaeda which included around 2,000 trained soldiers, into the Taliban force is a concrete example of the Taliban's reliance on foreign fighters, particularly al-Qaeda. ${ }^{542}$ Services in this unit, based in Khairkhana in northern Kabul, constituted part of the training of militants who came to Afghanistan, and the unit also supplied the "most committed and effective part of the Taliban military." ${ }^{" 43}$ The finding shows

\footnotetext{
${ }^{537}$ See for example, Sharia 3(19), April 1, 1998, p. 1; Sharia 3(53), August 9, 1998; Sharia 3(54), August 12, 1998; Sharia 3(55), August 16, 1998, p. 1; Sharia 3(55), 16 August 1998:1; Sharia 3(58), August 26, 1998, p. 1; Sharia 4(56) August 4, 1999, p. 1.

538 Payam-e-Mujahid 3(31), October 21, 2000; Payam-e-Mujahid 3(33), November 4, 2000; Payam-e-Mujahid 4(16) July 6, 2000; 4(47) February 8, 2001; Payam-e-Mujahid 5(12), June 7, 2001: 2; Payam-e-Mujahid 5(25), September 6, 2001; Payam-e-Mujahin 2(29), October 8, 1998, p. 1; Payam Mujahid, 2(16) July 9, 1998, p. 1.

${ }^{539}$ Rashid, Taliban, p. 194

${ }^{540}$ Payam-e-Mujahin 2(18) July 3, 1997, p. 6

${ }^{541}$ Mahmood Mamdani, Good Muslim, Bad Muslim (New York: Pantheon Books, 2004), p. 162.

${ }^{542}$ Mohamed Mahmoud Ould Mohamedou, Understanding al-Qaeda: the Transformation of War (London: Pluto Press), p. 49.

${ }^{543}$ Rubin, The Fragmentation of Afghanistan, p. xv.
} 
that between 2,000 and 3,000 Arabs under the command of Osama bin Laden fought for the Taliban, as did the Islamic Movement of Uzbekistan, the Pakistani Sipahi-i-Sahaba, Lashkar-iJangavi, Harakat-ul-Mujahidin, and Chechen and Uyghur jihadi networks. ${ }^{544}$ The Taliban received financial and military support from these organizations in return for providing them with sanctuaries in Afghanistan. Weak military and security apparatus and therefore the Taliban's military dependence on foreigner fighters were favorable conditions under which many jihadist groups mushroomed in Afghanistan. Al-Qaeda was one of the several organizations that nurtured in Afghanistan under the IEA's lack of authority condition and, thus, due to the IEA's need to transitional jihadi organizations' military support.

Moreover, lack of state control over its borders facilitated cross-border jihadi activities and interaction, and their infiltration into Afghanistan. Those jihadis organized in al-Qaeda camps emerged in ungoverned areas mostly in southern and eastern parts of Afghanistan. Even if the Taliban had full authority over the areas where al-Qaeda camps mushroomed, the group did not intend to stop them, simply because of the Taliban's heavy dependence on al-Qaeda's military aid and manpower. Hence, the IEA, despite massive international pressure and sanction, refused to submit bin Laden to the United States or any other country considering him a "Muslim mahagir/immigrant" and a guest in the dar-al-Islam, the house of Islam. ${ }^{545}$ Following the US cruise missile attacks on al-Qaeda camps in Afghanistan in response to al-Qaeda attacks on the US embassies in Nairobi and Dar al-Salam in August 1998, Mullah Omer state:

\footnotetext{
${ }^{544}$ Rubin, The Fragmentation of Afghanistan, xvi; Ahmed Rashid, "Afghanistan Resistance Leader Feared Dead in Blast," The Telegraph, September 11, 2001

(http://www.telegraph.co.uk/news/worldnews/asia/afghanistan/1340244/Afghanistan-resistance-leader-feared-deadin-blast.html).

545 Sharia 3(57), 23 August, 1998: 1; Sharia, 4(53), July 18, 1998: 1, 4; Sharia 4(81), October 31, 1999: 1; Sharia 4(96), December 22, 1999: 4; Sharia, 6(45), June 27, 2001: 2.
} 
"Osama is an individual, we moved him to a safe place, the US attacks are amiss... the Americans do not have any proof or evidence to accuse Osama... we are ready to face further attacks but will not submit Osama to America at any cost, even if we face tremendous difficulties and even if [the Americans] entirely destroy Afghanistan."546

The IEA's lack of sufficient military and security forces and its reliance on bin Laden's military aid were the main conditions that helped bin Laden to safely operationalize his idea of al-Qaeda in Afghanistan. Bin Laden used the condition provided by the IEA's lack of authority to bring several jihadi groups and thousands of young jihadi fighters in Afghanistan, building training camps and connecting them systematically under a core group, and launching the al-Qaeda organization formally in 1998.

\section{Lack of Capacity}

In addition to the lack of legitimacy and authority, the severe economic decline in Afghanistan and the IEA's lack of institutional and administrative capacity to extract official revenue was another condition which magnified the causal effects of the rise of al-Qaeda. The IEA neither had sufficient economic size nor did it enjoy an administrative capacity to produce revenue for covering its costs. When the Taliban captured Kabul in September 1996, it inherited a totally collapsed state with its infrastructures destroyed, its wealth looted, and its professionals fled the country as a consequence of the civil war. Therefore, the IEA's capacity was affected by three problems: a small economic size, a destructed governing institutions, and a weak administration. The IEA's source of the legal

\footnotetext{
${ }^{546}$ Sharia 3(57), 23 August, 1998: 1
} 
economy was too small to manage a state with, the state establishments were entirely destroyed, and the IEA's administration was filled with individuals roughly with a madrasa education. ${ }^{547}$

According to Tilly (1985), a sovereign state carries out four major duties: 'war-making' or the elimination of the state's external enemies, "state-making" or the elimination of the state's internal rivals, protection or the elimination/neutralization of the enemies of its clients, and extraction or acquiring the means of carrying out the first three activities. ${ }^{548}$ In this formulation, extraction refers to the state's capacity or capability to conduct its primary duties by extracting resources. Capacity includes the human and financial resources that a state has at its disposal. ${ }^{549}$ Capacity depends on two factors, a state's size of the economy and its capability for acquiring the means of governance. The smaller the pool of resources and the fiscal instrument, the more difficult is the work of extracting resources to sustain the war and other governmental activities. ${ }^{550}$ The IEA's capacity, in this sense, was massively affected by its very small economy and the low administrative capability for acquiring resources and providing basic services.

The IEA's regular source of revenue produced some 40 percent of its costs and, therefore, its economy was largely dependent on foreign aid and the drug economy. ${ }^{551}$ Per capita income of the 25 million population, in this period, was under $\$ 200$, and the country was close to a total economic collapse. ${ }^{552}$ The IEA had no annual budget but it appeared to spend $\$ 300$ million a year,

\footnotetext{
${ }^{547}$ Michael Semple, "Rhetoric, Ideology, and Organizational Structure of the Taliban," United States Institute of Peace: Peaceworks, No. 102, p. 6. (https://www.usip.org/sites/default/files/PW102-RhetoricIdeology-and-Organizational-Structure-of-the-Taliban-Movement.pdf).

548 Tilly, "War Making and State Making as Organized Crime," p. 181.

${ }^{549}$ Carment et al., Security, Development, and the Fragile State, 86.

550 Tilly, "War Making and State Making as Organized Crime," p. 182.

${ }^{551}$ Graciana del Castillo, Rebuilding War-Torn States: The Challenge of Post-Conflict Economic Reconstruction (Oxford University Press; 2008), p. 167; R Skaine, Women of Afghanistan in the Post-Taliban Era: How Lives Have Changed and Where They Stand Today (North Carolina, London: McFarland \& Company, Inc, Publishers, 2008), p. 57.

552 Del Castillo, Rebuilding War-Torn States, p. 167; Skaine, Women of Afghanistan in the Post-Taliban Era, p. 57.
} 
nearly all of it on war. ${ }^{553}$ The IEA's main official source of revenue was the transit trade between Afghanistan and Pakistan which had an estimated turnover of $\$ 4.5$ billion, with the Taliban receiving between $\$ 100$ and $\$ 130$ million per year which covered roughly between 33 to 43 percent of its costs. ${ }^{554}$

Due to the shortage of official revenue, the IEA relied partly on three unofficial sources: drug, the Pakistanis, and bin Laden. ${ }^{555}$ The IEA controlled 96\% of Afghanistan's poppy fields making opium its largest source of taxation. ${ }^{556}$ Taxes on opium exports became one of the mainstays of Taliban's income and its war economy. ${ }^{557}$ By 2000, Afghanistan accounted for an estimated $75 \%$ of the world's supply, and in 2000 it grew an estimated 3276 tons of opium from poppy cultivation on 82,171 hectares. ${ }^{558}$ The IEA, due to international pressures, banned the poppy cultivation in mid-2000 by issuing a "counternarcotic act." ${ }^{559}$ But prior to it, the IEA had extracted a large amount of money by imposing taxation on the poppy by leveling the ushr, a 10 percent tax on all agricultural production. ${ }^{560}$ This brought in some $\$ 6$ million a year from the $\$ 60$ million Afghan growers and traders earned from opium exports out of a business worth $\$ 40$ billion in Europe alone. ${ }^{561}$

The second unofficial source of the IEA's revenue was the financial support it received from the Pakistanis, particularly from the Pakistani Army and the ISI. Pakistan, in addition to its

\footnotetext{
${ }^{553}$ Pierre-Arnaud Chouvy, Opium: uncovering the politics of the poppy (Cambridge: Harvard University Press, 2010), p. 52.

${ }^{554}$ Chouvy, Opium, p. 52; Nojumi, The Rise of the Taliban in Afghanistan, p. 178.

${ }_{555}^{555}$ Chouvy Opium, p. 52.

${ }^{556}$ Ibid.

557 Ibid.

${ }^{558}$ Francisco E. Thourni, “The Rise of Two Drug Tigers: The Development of Illegal Drug Industry and Drug Policy Failure in Afghanistan and Colombia," in Frank Bovenkerk and Michael Levi eds., The Organized Crime

Community: Essays in Honor of Alan A. Block (New York: Springer, 2007), p. 130.

${ }^{559}$ See the Counternarcotic Act, Official Gazette, No. 793, August 1, 2000, articles. 1-5.

${ }^{560}$ Nojumi, The Rise of the Taliban in Afghanistan, p. 177; for Ushr rates see Sayyed Vali Reza Nasr, Islamic Leviathan: Islam and the Making of the State Power (New York, NY: Oxford University Press, 2001), 144.

${ }^{561}$ Nojumi, The Rise of the Taliban in Afghanistan, p. 177.
} 
official trade relations with IEA, largely contributed to the Taliban costs of war. ISI, for instance, had prepared a budget of some 2 billion rupees ( $\$ 5$ million) for logistical support for the Taliban. ${ }^{562}$ In addition to ISI's direct financial injection to the IEA, it provided the group with massive military and logistical supplies. Almost all Taliban combatants were trained by Pakistani elements, and Pakistan's civil and military presence was apparent everywhere in Afghanistan. For instance, in an April and May 2001 report, the Human Rights Watch highlighted that as many as thirty trucks a day were crossing the Pakistan border. ${ }^{563}$ A 1997 report of the US Secretary General confirmed such deliveries from Pakistan to Afghanistan. ${ }^{564}$

The third major source of IEA's revenue was the financial support it received from Arab jihadis, particularly bin Laden. According to a '9/11 Commission staff monograph,' once bin Laden moved to Afghanistan he provided a considerable part of the IEA's costs, paying it an amount between $\$ 10$ and $\$ 20$ million per year. The monograph emphasized that IEA's reliance on bin Laden increased over time: "As time passed, it appeared that the Taliban relied on al-Qaeda for an ever-greater share of their needs, such as arms, goods, and vehicles."565 The IEA's lack of sufficient source of revenue undermined the state's capacity in providing basic services. The state did not have enough money to pay its employees and keep service-providing institutions such as hospitals and schools running. The IEA itself openly mentioned the effects of economic shortage on its capacity:

\footnotetext{
562 Rashid, Taliban,p. 72.

${ }^{563}$ Human Rights Watch, Pakistan's Support of the Taliban.

${ }^{564}$ U.N. Secretary General, "The Situation in Afghanistan and Its Implications for International Peace and Security," Report of the Secretary-General, S/1997/894, November 14, 1997, para. 18.

${ }^{565}$ National Commission on Terrorist Attacks Upon the United States, "Al Qaeda's Means and Methods to Raise, Move, and Use Money," Terrorist Financing Staff Monograph, chap. 2, 2004, p. 28

(http://govinfo.library.unt.edu/911/staff_statements/911_TerrFin_Ch2.pdf).
} 
"The advancement of development activities in Afghanistan depends on large financial resources. There is no achievement in this regard because Afghanistan is experiencing huge economic problems."${ }^{, 566}$

The IEA spent all its revenue on "war-making" and the elimination of its internal rival, the NA. According to the IEA's official documents, the state's investment on development and service providing projects was very small. An IEA official report in 2000, for example, reports the government's investment of some $\$ 800,000$ from internal resources to complete 766 reconstruction and economic development projects, including the reconstruction of agricultural stores, powers stations and systems, post offices and a number of government establishments in Kabul and beyond. This report claims a $\$ 100,000$ increase in IEA's investment on development projects compare to previous year. ${ }^{567}$ Other reports indicate the IEA's engagement in very small development and service providing projects such rebuilding a few public libraries and madrasas, responding to emergency needs and reconstruction of some urban streets and provincial governmental establishments. ${ }^{568}$

The IEA's difficult economic situation was intensified by international economic sanctions that were imposed because of the Taliban's violation of human rights and its association with bin Laden and his terrorist group. In a public statement the IEA, explaining the womens' situation in Afghanistan, stated that the country needed humanitarian assistance instead of sanctions:

"The accusation of the violation of women's rights by the IEA is just a lie... the educated Afghan women expressed their wishes in a glorious ceremony on the women international day on March 8 in Kabul... and called on the world that

\footnotetext{
${ }^{566}$ Sharia 5(7), January 26, 2000, 1.

${ }^{567}$ Sharia 5(15), February 23, 2000, $1,4$.

568 Sharia 5(26), April 9, 2000, 1; Sharia 3(12), March 8, 1998, 1; Sharia 3(8), February 18, 1998, 1; Sharia, 3(9) February 22, 1998, 1; Sharia, 3(9), March 4, 1998.
} 
instead of economic sanctions which has increased the food prices and therefore the women problem, the international community should solve the existing problems in front of women in Afghanistan by launching humanitarian assistance projects..."

In a subsequent statement, the IEA rejected the existence of any terrorist activities in Afghanistan highlighting that the sanctions had an enormous impact on the IEA and its citizens. ${ }^{570}$ In a press conference in Islamabad, the IEA's ambassador to Pakistan, Mullah Abdul Salam Zayeef explained the humanitarian costs of the sanctions a massive by highlighting a few examples as follows:

"The sanctions have stopped the Ariana Airline which transported medicine into Afghanistan. It also affected people's life by stopping the postal and telecommunication services, and enhancing the food price. ${ }^{, 571}$

Considering the economic problems and the low service providing capacity of the IEA, almost all basic services depended on international aid. For example, more than half of Kabul's 1.2 million people benefitted in some way from NGOs.${ }^{572}$ Food distribution, health care, and the city's fragile water distribution network largely depended on NGO aid. ${ }^{573}$ These services stopped immediately after the Taliban's ban on NGOs in July 1998, when those organizations refused to relocate to a disused former polytechnic college. ${ }^{574}$ The Taliban's purpose of relocating the NGOs in a specified place was to keep their activities under effective control. The IEA's Planning Minister, Qari Din

\footnotetext{
${ }^{569}$ Sharia 5(26), April 9, 2000, 4.

${ }^{570}$ Sharia 5(40), June 11, 2000, $1,4$.

${ }^{571}$ Sharia, 5(89) December 2, 2000, 1, 4.

${ }^{572}$ Rashid, Taliban, 64-65; Kamran Abbasi, “Aid Agencies Pulled Out of Kabul,” BMJ, August 8, 1998 (http://www.bmj.com/content/317/7155/369.2).

${ }_{573}$ Rashid, Taliban, 64-65.

${ }^{574}$ Ibid.
} 
Mohammed, responded to the people's concerns about the banning of NGO services in Kabul was as follows:

"We Muslims believe that God the Almighty will feed everybody one way or another. If the foreign NGOs leave then it is their decision. We have not expelled them." $" 575$

Even if Afghanistan's state institutions were not destroyed, the Taliban did not have the necessary administrative capacity to run them appropriately. Almost all IEA authorities were armed Talibs and mullahs with nearly no modern administrative knowledge or expertise. ${ }^{576}$ Because most educated and professional Afghans had left the country during the war, the shortage of trained and skilled professionals in the IEA was intense. Almost all cabinet ministers, deputies, and provincial governors were mullahs roughly with a madrasa education who simultaneously acted as military commanders. For example, the Health Minister, Mullah Mohammed Abbas, served as a Taliban commander in Mazar and Herat in 1997 until he returned to his job as the Minister after six months of military services. ${ }^{577}$ Likewise, the Governor of the State Bank, Mullah Ehsanullah Ehsan, commanded an elite force of some 1,000 Kandahari Taliban, and the Governor of Herat, Mullah Abdul Razaq, led military offensives all over the country. ${ }^{578}$ Moreover, the IEA replaced all senior Tajik, Uzbek and Hazara bureaucrats with Talibs and Mullahs, whether qualified or not. ${ }^{579}$ Putting uneducated and inexperienced individuals on top of the state administration created a situation in which ministries ceased functioning and local administrations turned into military bases. The absence of skilled professionals in the IEA was obvious in all areas of governance. For example,

\footnotetext{
${ }^{575}$ Ibid., 72.

${ }^{576}$ Semple, Rhetoric, Ideology, and Organizational Structure of the Taliban, 6.

${ }^{577}$ Rashid, Taliban, 100-101.

578 Ibid.

${ }^{579}$ Ibid., 101.
} 
the IEA's negotiating team with the oil companies that were competing over a pipeline which was planned to connect Central Asian natural gas and oil to Pakistan was composed of nine mullahs and one engineer. ${ }^{580}$ The Taliban's lack of administrative capacity is well expressed in a 1997 note on the IEA's Ministry of Finance by the Pakistani journalist, Ahmed Rashid:

"The Ministry of Finance can barely put together a budget, and not just because funds are scarce. The Ministry has no qualified economists: the minister and his deputy are mullahs with a madrasa education." 581

Overall, weak administrative capacity particularly in the areas of war and finance, lack of a sufficient size of economy and official sources of revenue, and therefore, the IEA's reliance on three illegal sources of revenue, particularly the Arabs, favored the formation of al-Qaeda. First of all, it made the IEA financially dependent on bin Laden's funds. According to a ' $9 / 11$ Commission staff monograph,' once bin Laden moved to Afghanistan he provided a considerable part of the Taliban's costs, paying them an amount between $\$ 10$ to $\$ 20$ million per year: “As time passed, it appeared that the Taliban relied on al-Qaeda for an ever-greater share of their needs, such as arms, goods, and vehicles." ${ }^{" 52}$ The ambitious Arab businessman invested in the Taliban and the Taliban in return provided him with a safe haven. ${ }^{583}$ The emergence of al-Qaeda, in this sense, was based on a mutual interest between bin Laden and the IEA. Likewise, the IEA's revenue depended on Pakistanis while Pakistan, particularly its army, traditionally considers the formation and expansion of Salafi-jihadi groups in the region as favorable to its foreign policy ${ }^{584}$ In very popular

\footnotetext{
${ }^{580}$ Nojumi, The Rise of the Taliban in Afghanistan, 176-77.

${ }^{581}$ Ibid., 176.

582 John Roth, Douglas Greenburg and Serena Wille, “Al Qaeda's Means and Methods to Raise, Move, and Use Money," National Commission on Terrorist Attacks Upon the United States: Terrorist Financing Staff Monograph, 2004: 28 (http://govinfo.library.unt.edu/911/staff_statements/911_TerrFin_Ch2.pdf).

${ }^{583}$ Mark Juergensmeyer, “the Legitimacy of Invading Religious Regimes," 275.

${ }^{584}$ C. Christine Fair, Fighting to the End: The Pakistan Army's Way of War (New York: Oxford University Press, 2014); Zachari Laub, "Pakistan's New Generation of Terrorists," Council on Foreign Relations, November 18, 2013. Retrieved from https://www.cfr.org/backgrounder/pakistans-new-generation-terrorists
} 
cases, Pakistan used Hizb-i-Islami and the Taliban in Afghanistan, and Jaish-e-Muhammad (Army of Muhammad) and Lashkar-i-Taiba in Kashmir. ${ }^{585}$ Therefore, the formation of al-Qaeda to Pakistanis meant the establishment of another militant organization in favor of its foreign policy without costs. Evidence shows that Pakistan's armed forces personnel and the ISI field officers worked closely with Arab jihadis in Afghanistan and thousands of Pakistani soldiers were integrated with Arab fighters in the Taliban's military units. ${ }^{586}$

Furthermore, the IEA spent almost all of its revenue on war and, therefore, the ones who managed the money managed the war. Since the IEA's financial management system was filled with individuals with very poor administrative capacity, its financial, and therefore, military management depended on foreigners particularly Arabs and Pakistanis. Arab militants, especially bin Laden, benefitted significantly from this situation. He managed to lead the Taliban's financial and thus 'war-making' apparatuses in a direction which did not cross his 'camp-making' activities. Thus, lack of capacity both in terms of lack of a sufficient source of revenue and a capable administration was a favorable condition for the establishment of al-Qaeda in Afghanistan.

Thus, al-Qaeda emerged under the conditions provided by state fragility during the IEA. Regardless of the terrorist organization's emergence and expansion in Afghanistan, the IEA ignored publicly the term 'al-Qaeda' and its existence in Afghanistan, until the US invasion in late 2001. A review of the IEA's official publications, particularly the Sharia, from 1996 to 2001 shows that the term 'al-Qaeda' was used only in the last issue of the Sharia in November 2001. Publishing

\footnotetext{
585 John Moore, “The Evolution of Islamic Terrorism: An Overview," PBS (http://www.pbs.org/wgbh/pages/frontline/shows/target/etc/modern.html).

586 Rashid, Taliban, 194; Peter Tomsen, The Wars of Afghanistan: Messianic Terrorism, Tribal Conflicts, and the Failures of Great Powers (New York: PublicAffairs, 2011), 322; Ahmed Rashid, "Pakistan and the Taliban." In William Maley ed., Fundamentalism Reborn? Afghanistan and the Taliban (New York: New York University Press, 1998), 72-88; Rubin, The Fragmentation of Afghanistan, xvi; Ahmed Rashid, “Afghanistan Resistance Leader Feared Dead in Blast," The Telegraph, September 11, 2001 (http://www.telegraph.co.uk/news/worldnews/asia/afghanistan/1340244/Afghanistan-resistance-leader-feared-deadin-blast.html).
} 
the photo of a destroyed building, allegedly bombed by the American B52 fighters, the Sharia stated: "these are public services establishments, not 'al-Qaeda' camps." 587

${ }^{587}$ Sharia, 6(78), November 5, 2001: 1. 


\section{V}

\section{Root Causes of IS}

Islamic State is a Salafi-jihadi organization which seeks, first, to destroy the regional status quo by breaking modern states in the Middle East, and second, to establish a worldwide Islamic caliphate. Although some scholars believe that IS, unlike al-Qaeda, views the struggle against the far enemy as a secondary goal that must be deferred until a Sunni caliphate is built in the heart of Arabia, ${ }^{588}$ IS's activities in past years have shown that the organization's concentration on attacking a specific enemy depends on complicated conditions and changes over time. Moreover, regardless of IS's tactical differences from al-Qaeda, ${ }^{589}$ the two group share the same ideology and follow the same ultimate goal of establishing a global Islamic caliphate. ${ }^{590}$ Like al-Qaeda, IS broadly relies on Salafi-Jihadi ideology in which restoring the caliphate is the key. Therefore, regardless of IS's different tactical priorities and institutional structure, it relies on al-Qaeda's Salafi-Jihadi ideology of creating an Islamic caliphate as the core of a new international order in which a single Islamic caliphate would replace all Muslim nation-states.

Since its emergence, IS has periodically shifted its tactical focus from attacking Riyadh, Baghdad, and Damascus to Western cities and vice versa. Although regional targets are IS's immediate military priority, its affiliates have managed simultaneous terrorist attacks in Paris, Brussels, London, Orlando and other Western cities. IS's multilateralism, in this sense, is broader

\footnotetext{
${ }^{588}$ Fawaz A. Gerges, ISIS: A History (Princeton: Princeton University Press, 2016), 6; Charles R. Lister, The Islamic State: A Brief Introduction (Washington D. C.: The Brookings Institute Press, 2015), viii.

${ }^{589}$ Charles R. Lister, The Islamic State: A Brief Introduction (Washington D. C.: The Brookings Institute Press, 2015), viii.

${ }^{590}$ Harleen Gambhir, "ISIS's Global Strategy: A Wargame," The Institute for Study of War, Middle East Security Report 28, July 2015: 7-9.
} 
and more complex than al-Qaeda's Western-centric strategy. Overall, IS's objective is to expand its caliphate in the Middle East and the broader Muslim world and lead, simultaneously, a global apocalyptic war. In order to do so, IS has framed a strategy to expand across three geopolitical rings: the Interior Ring, the Near Abroad Ring, and the Far Abroad Ring. ${ }^{591}$

The Interior Ring of Iraq and Syria is the center of IS's campaign. ${ }^{592}$ The principal method of IS on the Interior Ring is "aggressive defense," which is to degrade and eventually destroy state militaries, paramilitaries, and other jihadi groups that might challenge its control in Iraq and Syria. ${ }^{593}$ In contrast, the Near Abroad Ring includes the "Islamic lands" which IS intends to integrate into its caliphate. The principal method of IS in this Ring is both defensive and offensive, and its primary purpose is expansion of the caliphate through the creation of regional affiliates. ${ }^{594}$ IS encourages local groups to pledge allegiance to the organization, unite under a single banner, and designate a leader to whom IS can direct resources and sustained engagement. ${ }^{55}$ Through this method, IS announced the creation of governorates, or wilayats, in Algeria, Libya, Saudi Arabia, Yemen, and Egypt's Sinai Peninsula in November 2014. It also declared the wilayat of Khurasan which includes Afghanistan and Pakistan in January 2015, added the Caucasus on July 23, 2015 and called the West Africa as the wilayat of Maghreb. ${ }^{596}$ Wilayats give IS resiliency in case it suffers losses in the Interior Ring. ${ }^{597}$ IS's wilayats are geographically dispersed across the Muslim world which are created to develop conflict zones and sanctuaries in different regions. ${ }^{598}$ IS's Far

\footnotetext{
591 Gambhir, "ISIS's Global Strategy," 9-10.

592 The Levant or the greater Syria includes Syria, Lebanon, Jordan and Israel-Palestine.

${ }^{593}$ Gambhir, "ISIS's Global Strategy," 10.

594 Ibid., 11.

595 Ibid.

${ }^{596}$ Ibid; Harleen Gambhir, "ISIS Declares Governorate in Russia's North Caucasus Region," Institute for the Study of War, June 23, 2015.

${ }^{597}$ Gambhir, "ISIS's Global Strategy," 11; Harleen Gambhir, "ISIS Global Intelligence Summery," Institute for the Study of War, March 1-May 7 2015: 4-8.

598 Gambhir, "ISIS's Global Strategy," 11.
} 
Abroad Ring includes Europe, the Americas, and Asia in which the group's principal method involves encouraging and resourcing terrorist attacks. ${ }^{599}$ IS's plan in this Ring is to motivate the Western states and societies to target and alienate Muslim communities due to these attacks. This would push Muslim populations away from Western societies and, thus, toward the caliphate. ${ }^{600}$ IS's "sleeper cells" in the Far Abroad Ring recruit fighters to join the war in Interior Ring and plan terrorist attacks in the Far Abroad Ring. ${ }^{601}$ IS's campaign in the three Rings is "distinct, simultaneous, and mutually supportive," with operations in the Far and Near Abroad rings giving the organization strategic resiliency in case it loses territory in the Interior Ring. When IS comes under pressure in one ring, it plans attacks in another ring. For example, IS accelerated activities in the Near and Far Abroad rings after it lost Tikrit in April 2015. ${ }^{602}$

The emergence of this territorially expandable and strategically flexible SJG opened a new chapter in the history of SJGs which requires special attention. IS's organizational complexity, and strategic flexibility and multilateralism are the result of the organization's complex evolution from several regional and global jihadi and insurgent organizations that primarily emerged as distinct anti-American and anti-Shiite groups following the US invasion of Iraq in April 2003. There are several narratives of the emergence of IS. However, the narrative which traces the origins of IS to the emergence of the Iraqi branch of al-Qaeda, al-Qaeda in Iraq (AQI), is the most popular one. According to this narrative, IS developed from several insurgent and jihadi groups that primarily emerged as a response to the US invasion of Iraq and its consequences and subsequently merged into AQI. Following a number of events, AQI developed into ISI, which in turn transformed into ISIS and ultimately IS. Drawing on this narrative, I track the antecedent elements of the

\footnotetext{
${ }^{599}$ Ibid., 12.

${ }^{600}$ Ibid.

${ }^{601}$ Ibid.

${ }^{602}$ Ibid.
} 
establishment of IS from the American invasion of Afghanistan in late 2001, and the search for root causes of the emergence of IS in the American invasion of Iraq and its political, economic and social consequences.

\section{Post-Saddam Insurgency}

Following the US invasion of Iraq in April 2003, anti-occupation sentiments expanded in Baghdad and other parts of Iraq. As early as May 2003, two anti-invasion movements emerged throughout Iraq. First, a Shiite rebellion led by cleric Muqtada al-Sadr emerged in parts of Baghdad and the southern city of Najaf. The Shiite reaction was more like a rebellion because its objective was to influence the Shiite-dominated government in Baghdad, rather than removing it. Second, a Sunni insurgency, concentrated mainly in the Sunni Triangle, an area bound by Baghdad in the east, Ramadi to the west and Tikrit to the North. ${ }^{603}$ Due to the main concentration of the post-Saddam insurgency in this area, the Americans called it the 'triangle of death.' ${ }^{604}$

Unlike the Shiite rebellion, the Sunni insurgency was composed of homegrown and transnational jihadis, and Iraqi Baathists whose main objective was to completely remove the Shiite-led, American-sponsored government. ${ }^{605}$ The Sunni insurgency was composed mainly of two categories. First, remnants of the Saddam regime's security and military services, exBaathists, and neo-Baathists who had access to the stockpiles of weaponry across the country and the vast financial resources of the Baath party. ${ }^{606}$ Second, the extremist Islamist groups that included domestic and transnational groups including al-Qaeda affiliates. ${ }^{607}$

\footnotetext{
${ }^{603}$ Ahmad Hashim, Insurgency and Counter-Insurgency in Iraq (Ithaca, New York: Cornell University Press, 2006), 129.

${ }^{604}$ Anthony Shadid, “Iraq's Forbidding 'Triangle of Death',' The Washington Post, November 23, 2004

(http://www.washingtonpost.com/wp-dyn/articles/A5710-2004Nov22.html).

605 Stansfield, Iraq, 176.

606 Stansfield, Iraq, 178-79; Dodge Iraq's Future, 10

${ }^{607}$ Stansfield, Iraq, 181.
} 
The longest existing domestic extremist group in Iraq was Ansar al-Islam, an Islamist militia based in northeast Iraq. Iraqi militants trained in Taliban-run Afghanistan and the Jordanian Jihadist, Abu Musab al-Zarqawi's Jabhat al-Tawhid wal-Jihad (JTJ) trained Ansar al-Islam, months before the American invasion, to fight an expected invasion. The early joint training took place in the camps of Ansar al-Islam located in mountainous areas of the Kurdistan region of Iraq, which was bombed in the early days of 'Operation Iraqi Freedom.' ${ }^{608}$ As soon as the invasion started, JTJ and other jihadis moved into the Sunni Triangle. In the first year of occupation, the Sunni insurgency included transnational jihadis such as the JTJ and al-Qaeda affiliates, domestic jihadi groups, and the Baathists which included the former Iraqi armed forces, and well-trained officers and soldiers. IS was the outcome of the gradual incorporation of these three elements under the doctrine of the caliphate, the Salafi-jihadi ideology.

\section{Zarqawi and the Doctrine of the Caliphate}

The development of the Iraqi-based insurgency into AQI and its evolution into IS was initially inspired by Zarqawi's doctrine of international jihadism and the establishing a pan-Islamic caliphate. ${ }^{609}$ Zarqawi (1966-2006) was a Jordanian jihadi who volunteered to Afghanistan first in 1989 where he stayed until 1993. ${ }^{610}$ He went to Afghanistan to fight in the Afghan war's second phase against the Soviet-backed PDPA regime. Following the Soviet Union's withdrawal from Afghanistan, a large number of Afghan Arabs returned to their home countries, however, a remarkable number stayed to help the Afghan mujahidin fight against Najibullah's regime which

\footnotetext{
608 “Terrorism Havens: Iraq," Council on Foreign Relation, December 1, 2005 (http://www.cfr.org/iraq/terrorismhavens-iraq/p9513).

${ }^{609}$ David Ignatius, "How ISIS Spread in the Middle East: And How to Stop It," The Atlantic, October 29, 2015 (http://www.theatlantic.com/international/archive/2015/10/how-isis-started-syria-iraq/412042/).

${ }^{610}$ Mary Anne Weaver, "The Short, Violent Life of Abu Musab al-Zarqawi," The Atlantic, July/August 2006 (http://www.theatlantic.com/magazine/archive/2006/07/the-short-violent-life-of-abu-musab-al-zarqawi/304983/).
} 
is considered as the second phase of the Afghan war. During his stay in Afghanistan, Zarqawi, like many other Afghan Arabs, interacted with doctrinaires of Islamism from across the Muslim world. Although Zarqawi did not meet bin Laden at this time, he was trained in one of his and Azzam's camps, the Sada camp near the Afghan border inside Pakistan. ${ }^{611}$ He was also introduced to Sheikh Abu Muhammad al-Maqdisi, a Palestinian jihadi cleric, who became Zarqawi's mentor. ${ }^{612}$

Zarqawi and Maqdisi left Afghanistan in 1993 and returned to Jordan, where they formed a jihadi group called Bayat al-Imam to fight the Hashemite monarchy. ${ }^{613}$ When Bayat al-Imam's terrorist activities caught the attention of Jordanian authorities, Zarqawi and Maqdisi were arrested by the Jordanian intelligence. In 1994, Zarqawi was sentenced to 15 years in Sawaqa prison where he was accompanied by Maqdisi. ${ }^{614}$ During their time in prison, Zarqawi and Maqdisi were able to use Zarqawi's tribal affiliations to expand Bayat al-Imam inside and outside the prison. ${ }^{615}$ Through these activities, Zarqawi influenced and controlled a large number of imprisoned jihadis who called him Amir, the chief. ${ }^{616}$ In 1999, Zarqawi was released from the prison in a general amnesty by Jordan's King Abdullah. ${ }^{617}$ In 2000, after his plot to "bomb the Radisson SAS Hotel in Amman and several tourist sites in Jordan" was discovered in its last stage, Zarqawi fled to Pakistan. But after the Pakistani officials revoked his visa, Zarqawi crossed the border into Afghanistan for the second time where he made his first contacts with bin-Laden. ${ }^{618}$

\footnotetext{
${ }^{611}$ Weaver, "The Short, Violent Life of Abu Musab al-Zarqawi."

${ }^{612}$ Ibid.

${ }^{613}$ M. J. Kirdar, “Al-Qaeda in Iraq,” CSIS, Case Study Series: Case Study Number 1., June, 15, 2011: 2 (http://csis.org/files/publication/110614_Kirdar_AlQaedaIraq_Web.pdf).

${ }^{614}$ Kirdar, "Al-Qaeda in Iraq," 2; Weaver, "The Short, Violent Life of Abu Musab al-Zarqawi."

${ }^{615}$ Kirdar, "Al-Qaeda in Iraq," 3.

${ }^{616}$ Weaver, "The Short, Violent Life of Abu Musab al-Zarqawi."

${ }^{617}$ Kirdar, "Al-Qaeda in Iraq," 3. Weaver, "The Short, Violent Life of Abu Musab al-Zarqawi."

${ }^{618}$ Craig Whitlock, "al-Zarqawi's Biography," The Washington Post, June 8, 2006 (http://www.washingtonpost.com/wpdyn/content/article/2006/06/08/AR2006060800299.html?nav=rss_world/africa)
} 
During his stay in Afghanistan, Zarqawi received support from al-Qaeda, however, he did not submit to Bin Laden's authority due to his stricter theology and near-enemy centrism against Shiites. ${ }^{619}$ Zarqawi at the time, unlike bin-Laden, was a proponent of war against the near enemy, particularly the Shiites and secular Sunni regime, in the Middle East. Thus, the two had different views on jihad and, in addition, disagreed on any aspect of each other's personal and political behavior. Zarqawi, for instance, strongly criticized bin-Laden's support for the Taliban against the former Afghan mujahidin groups that Zarqawi was helping during his first stay in Afghanistan. In contrast, bin-Laden “disapproved Zarqawi’s 'swagger,' his tattooed hand, and his intense hatred of Shiites." ${ }^{620}$ Despite bin-Laden's skepticism on Zarqawi, Seif al-Adel, al Qaeda's security chief and a proponent of near enemy-centric jihad, supported Zarqawi's efforts against the Jordanian government. ${ }^{621}$ Adel's support to Zarqawi led al-Qaeda to help him with $\$ 200,000$ in cash and to facilitate the setting up of his own camp in Herat along the Afghan-Iranian border. ${ }^{62}$

In early 2000, with a dozen or so followers who had arrived from Peshawar and Amman, Zarqawi set up his camp in a desert in Herat province in West Afghanistan border to Iran. ${ }^{623}$ This camp was named Jamaat al-Tawhid wal-Jihad (JTJ) which primarily attracted only Jordanian jihadis. ${ }^{624}$ However, Zarqawi quickly attracted recruits from other nationals, particularly Palestinian and Syrian Islamists living in Europe. ${ }^{625}$ Zarqawi's plan for expanding the areas from which

\footnotetext{
${ }^{619}$ Cole Bunzel, "From Paper State to Caliphate: the Ideology of the Islamic State," The Brookings Institute, Analysis Paper No. 19, March 2015, 13.

${ }^{620}$ Weaver, "The Short, Violent Life of Abu Musab al-Zarqawi."

${ }^{621}$ Kirdar, "Al-Qaeda in Iraq," 3

${ }^{622}$ Charles Lister, "Profiling the Islamic State," The Brookings Institute, Brookings Doha Center Analysis Papers No.13, November 2014, 6; Weaver, "The Short, Violent Life of Abu Musab al-Zarqawi."

${ }^{623}$ Weaver, "The Short, Violent Life of Abu Musab al-Zarqawi."

${ }^{624}$ Whitlock, "al-Zarqawi’s Biography;" Craig Whitlock, "Zarqawi Building His Own Terror Network," The Washington Post, October 3, 2004 (http://old.post-gazette.com/pg/04277/388966.stm); Bill Roggio, "Exodus and Ascent," The Long War Journal, March 30, 2005 (http://www.longwarjournal.org/archives/2005/03/exodus_and_asce.php).

${ }^{65}$ Gary Gambill, “Abu Musab al-Zarqawi: A Biographical Sketch,” Jamestown Terrorism Monitor 2(24), December 15, 2004 (http://www.jamestown.org/single/?no cache=1\&tx ttnews[tt_news]=27304).
} 
he recruited was to turn his small group into "a mobile army which he could export to anywhere in the world. ${ }^{9626}$ His number of fighters multiplied from dozens to hundreds by mid-2001. By the October 2001 US invasion of Afghanistan, JTJ fighters and their families numbered some 2,000 to $3,000 .{ }^{627}$ As his network developed, Zarqawi abandoned his exclusive focus on overthrowing the Jordanian monarchy, in part because some of his operatives refused to go back to Jordan, preferring instead to plot attacks against Israel or Jewish targets in Europe ${ }^{628}$ Thus, during his stay in Herat, Zarqawi's near enemy-centric theory of jihad slowly transformed into far-enemycentrism, making him a full-fledged extremist Islamist commander who gradually became interested in plotting terrorist attacks everywhere in the world. ${ }^{629}$

Following the US invasion of Afghanistan in late 2001, Zarqawi's JTJ united with and fought alongside al-Qaeda and Taliban forces. However, the JTJ left the Afghan battlefield after only two months of fighting and slipped into Iran. ${ }^{630}$ Evidence shows that Zarqawi's followers were provided with housing and other assistance by elements linked to Gulbuddin Hekmatyar's Hizb-e-Islami of Afghanistan, based in Baluchistan province of Iran. ${ }^{631}$ Zarqawi attempted to base his group in Baluchistan, the eastern province of Iran. But arrests of some Europe-based JTJ operatives in early 2002 turned Western authorities' focus to Zarqawi's presence in Iran. As a result of international pressure on Iran to arrest Zarqawi, the JTJ turned into a mobile network moving between Iran, Syria, Lebanon, and the Kurdish-controlled areas of northern Iraq for the next 14 months. ${ }^{632}$

\footnotetext{
${ }^{626}$ Weaver, "The Short, Violent Life of Abu Musab al-Zarqawi."

627 Ibid.

${ }^{628}$ Gambill, “Abu Musab al-Zarqawi: A Biographical Sketch.”

${ }^{629}$ Weaver, "The Short, Violent Life of Abu Musab al-Zarqawi."

${ }^{630}$ Peter L. Bergen, The Longest War: The Enduring Conflict Between America and Al-Qaeda (New York: Free Press, 2011), 162; Loretta Napoleoni, Insurgent Iraq: Al-Zarqawi and the New Generation (New York: Seven Stories Press, 2005), 104-105.

${ }^{631}$ Lister, "Profiling the Islamic State," 6.

${ }^{632}$ Kirdar, "Al-Qaeda in Iraq," 3.
} 
In this period, Zarqawi was able to expand his network and grow his cadre of fighters. ${ }^{633}$ According to Arab intelligence sources, Zarqawi planned his military resistance to the expected US invasion as early as_February 2003 when he was in eastern Iran. ${ }^{634}$ According to British intelligence, by March 2003, Zarqawi's network "had set up sleeper cells in Baghdad" to resist invasion. ${ }^{635}$ By the time US forces invaded Iraq in March 2003, Zarqawi "mobilized his network of safe houses, weapons caches, and intelligence networks in Iraq in coordination with alQaeda core" which was based in Pakistan. ${ }^{636} \mathrm{He}$ traveled frequently to the Sunni Triangle expanding his network, recruiting fighters, and establishing further bases ${ }^{637}$ After his initial base in Ansar al-Islam camps in Biyara in the Kurdish province of Sulaymaniyah was bombed in March 2003, Zarqawi moved to the Triangle permanently ${ }^{638}$ Following the invasion, he put into action a five-pronged strategy in Iraq: to isolate Coalition forces, to deter Iraqi cooperation with the transition process, to assassinate collaborators with the occupation regime, to sabotage rebuilding projects, and to trap the US troops in a Sunni-Shiite civil war. ${ }^{639}$

Zarqawi's quick expansion of weapons, networks and attacks made him "the default Amir" of jihadis and insurgents in Iraq winning him the endorsement of bin Laden. ${ }^{640}$ As his prominence within the Iraqi insurgency reached its peak, an agreement was struck between him and bin Laden in October 2004 through which Zarqawi declared his allegiance to bin Laden and changed his group's name to Tanzim Qaidat al-Jihad fi Bilad al-Rafidayn, known as al-Qaeda in Iraq (AQI).

\footnotetext{
${ }^{633}$ Weaver, "The Short, Violent Life of Abu Musab al-Zarqawi."

${ }^{634}$ Whitlock, "Zarqawi Building His Own Terror Network."

635 Ibid.

${ }^{636}$ Bruce Reidel, “The Search for Al Qaeda: Its Leadership, Ideology, and Future,” Brookings Institution, $2008,98$.

${ }^{637}$ Kirdar, "Al-Qaeda in Iraq," 3; Weaver, "The Short, Violent Life of Abu Musab al-Zarqawi."

${ }^{638}$ Lister, "Profiling the Islamic State," 7.

${ }^{639}$ Kirdar, "Al-Qaeda in Iraq,” 4; Gambill, "Abu Musab al-Zarqawi: A Biographical Sketch.”

${ }^{640}$ Gambill, "Abu Musab al-Zarqawi: A Biographical Sketch;” Bobby Ghosh, "ISIS: A Short History,” The Atlantic, August 14, 2014 (http://www.theatlantic.com/international/archive/2014/08/isis-a-short-history/376030/).
} 
Zarqawi proclaimed himself to be the 'Amir of al-Qaeda's Operations in the Land of Mesopotamia. ${ }^{641}$

\section{From AQI to IS: The Formation of the Caliphate}

The increase of AQI's number of deadly attacks in and beyond Iraq developed massive anti-AQI reactions by American forces, Shiites, and even Sunni Arabs. On November 9, 2005, the global backlash against Zarqawi and his group reached its peak following AQI's coordinated bombings of three Amman hotels which killed 60 people, most of them Sunni Muslims attending a wedding party ${ }^{642}$ Following the bombings, more than 100,000 Jordanians took to the streets chanting, "Zarqawi, you coward, what brought you here?" ${ }^{643}$ In January 2006, in an effort to lower its profile, AQI merged with five other Iraqi-based jihadi groups ${ }^{644}$ forming the Mujahidin Shura Council, Majlis Shura al-Mujahedeen (MSM), an umbrella organization led by a council of member groups' leaders from which Zarqawi was excluded. ${ }^{645}$ Zarqawi maintained a low-profile until his death by a US airstrike on June 7, 2006. ${ }^{646}$ Following Zarqawi's death, a senior AQI commander named Abu Hamza al-Muhajir (Abu Ayyub al-Masri) replaced him as the leader of AQI. However, following Zarqawi's death, neither AQI nor MSM regained its effectiveness which led MSM leadership to rebrand the group. On October 15, 2006, an MSM spokesperson announced the establishment of the Islamic State of Iraq (ISI) with a structured cabinet and Abu Omar al-

\footnotetext{
${ }^{641}$ Kirdar, Al-Qaeda in Iraq," 4; Weaver, "The Short, Violent Life of Abu Musab al-Zarqawi."

${ }^{642}$ Kirdar, Al-Qaeda in Iraq," 4.

643 "Zarqawi 'Defends Jordan Attacks'," BBC News, November 18, 2005

(http://news.bbc.co.uk/2/hi/middle_east/4450590.stm).

${ }^{644}$ Namely, Jaish al-Ta'ifa al-Mansurah, Katbiyan Ansar Al-Tawhid wal Sunnah, Saray al-Jihad Group, al-Ghuraba Brigades, and al-Ahwal Brigades.

${ }^{645}$ Lister, "Profiling the Islamic State," 8; Joseph Felter and Brian Fishman, “Al-Qaeda's Foreign Fighters in Iraq: A First Look at the Sinjar Records," Combating Terrorism Center at West Point, January 5, 2008 (http://www.ctc.usma.edu/wp-content/uploads/2010/06/aqs-foreign-fighters-in-iraq.pdf).

${ }^{646}$ Kirdar, Al-Qaeda in Iraq," 5.
} 
Baghdadi as its emir. ${ }^{647}$ The establishment of ISI was intended to represent a qualitative evolution whereby an insurgent group transformed into a military-political actor responsible for governing a territory. ${ }^{648}$

The MSM's transformation into ISI was a big achievement for the Iraq-based insurgency. However, because of the ISI's extremist ideology and its Taliban-like rule in the tribal regions, through which one tribe could dominate other tribes, the newly formed organization faced huge resistance in Sunni tribal areas. ${ }^{649}$ This resistance was organized of locally formed tribal councils called Sahwa (awakening). Although it did not last longer than two years, the American sponsored Sahwa posed a serious challenge to the Iraq-based insurgency. Sahwa appeared initially in Anbar province and by early 2007 it expanded almost in all Sunni areas beginning a covert campaign of killing the ISI members. ${ }^{650}$ In addition to the emergence of Sahwa, the ISI also faced severe US pressure in 2007. In June 2007, the US deployed 20,000 additional troops in Iraq to eliminate the ISI. Together, the US and Sahwa campaign resulted in killing 2,400 people and capturing 8,800 ISI members in 2007. ${ }^{651}$ This sent an alarm of an expected elimination of insurgency in Iraq. Therefore, Sunni tribes, particularly the Anbar tribal leaders, began sending their members to join the Iraqi security services, hoping for reintegration into the post-invasion Iraqi political and sphere. ${ }^{652}$ By spring 2009, more than 100,000 Sunni tribesmen switched sides in favor of the USled Multi-National Force (MNF) and went on the US payroll. ${ }^{653}$ In addition to enhancing the counterterrorism momentum in the ground, the people that switched sides added a source of local intelligence collection to the MNF. The extension of the anti-ISI campaign severely undermined

\footnotetext{
${ }^{647}$ Lister, "Profiling the Islamic State," 8.

${ }^{648}$ Ibid., 9.

${ }^{649}$ Ibid.

${ }^{650}$ Ibid.; Bergen, The Longest War, 272; Kirdar, "Al-Qaeda in Iraq," 5.

${ }^{651}$ Bergen, The Longest War, 272; Kirdar, "Al-Qaeda in Iraq," 5.

${ }^{652}$ Bergen, The Longest War, 172.

${ }^{653}$ Ibid., 272; Kirdar, "Al-Qaeda in Iraq," 5.
} 
ISI's recruitment capacity and its transnational relations. The flow of foreign fighters into Iraq, for instance, withered from 120 per month to 45 . By early 2009 only 5 or 6 foreign fighters entered Iraq each month. ${ }^{654}$ Eventually, a leadership vacuum, after an Iraqi counterterror operation killed both Masri and Baghdadi on April 18, 2010, put the organization in a critical situation. ${ }^{655}$ Nevertheless, the group quickly appointed Abu Bakr al-Baghdadi as the Amir of ISI and AbuSulayman al-Nasir as the War Minister who respectively replaced Abu Omar al-Baghdadi and Masri. $^{656}$

Despite temporary achievements, the counterterrorist campaign in Iraq due to the US policy shift in mid-2009 shrank. The US military withdrawal from Iraq, between June 2009 and August 2010, which dramatically subverted the anti-ISI domestic forces, increased ISI's confidence and momentum. ${ }^{657}$ With the US military withdrawal underway, Sahwa militias broke up with Nouri al-Maliki's Shiite-dominated government due to its lack of support among Sunnis and unpaid wages. By mid-2010, ISI was offering larger salaries than the government to Sahwa members. ${ }^{658}$ As a result, ISI leadership regained confidence and recruiting capability by 2011 . By this time, the ISI leadership had also planned to restructure the organization in order to exhibit it as an Islamic army which would operate against the Western invasion and Shiite domination beyond sovereign boundaries. This reconsideration spotlights the dual anti-Western and anti-Shiite nature of the organization which was primarily inspired by Zarqawi's theory of jihad against the "CrusaderSafavid" alliance. ${ }^{659}$ In addition to the US withdrawal from Iraq and the subsequent Sahwa

\footnotetext{
${ }^{654}$ Kirdar, “Al-Qaeda in Iraq," 5.

${ }^{655}$ Ibid.

${ }^{656}$ Lauren Gelfand, “Al-Qaeda in Iraq Regroups and Names New Leadership,” Jane's Defense Weekly 47(21), May 19, 2010, 19; Kirdar, "Al-Qaeda in Iraq," 5.

${ }^{657}$ Lister, "Profiling the Islamic State," 10.

${ }^{658}$ Timothy Williams and Duraid Adnan, "Sunnis in Iraq Allied with U.S. Rejoin Rebels," The New York Times, 16 October 2010 (http://www.nytimes.com/2010/10/17/world/middleeast/17awakening.html?pagewanted=all\& r $=0$ ).

${ }^{659}$ Safavid or Safawi, refers to the Iranian Safawi dynasty (1501-1722). It is used by many Sunni Arab Iraqis today to describe the alleged Iranian influence and to discredit their Shiite fellow citizens as "aliens." The "Crusader-
} 
movement's defeat, the eruption of the civil war in Syria in mid-2011 accelerated the process of ISI's transformation into a transnational jihadi organization.

The emergence of a popular uprising in Syria in early 2011 and its development into a civil war in mid-2011 caught the attention of ISI's leader, Baghdadi, who planned to establish an ISI front in Syria by sending his Ninawa operation's chief, Abu Muhammad al-Jowlani. ${ }^{660}$ Jowlani arrived in Syria's northeastern Hasakah governorate in August 2011 and built connections with local jihadi cells across the country in order to establish what would become Jabhat al-Nusra (JN) ${ }^{661}$ The JN was launched formally on January 23,2012 by claiming a suicide bombing in Damascus in December 23, 2011 that killed at least 40 people. ${ }^{62}$ In the following six months, JN operated similarly to ISI without having any direct links to ISI or al-Qaeda ${ }^{663}$ By late 2012 , JN had become an effective jihadi organization numbering some 2,000 members. ${ }^{664}$ When JN was making remarkable achievements, on April 9, 2013, Baghdadi claimed in an audio statement that JN "was an offshoot of ISI and therefore it would be subsumed into the expanded Islamic State in Iraq and al-Sham. ${ }^{965}$ In fact, this statement marked the official development of ISI into ISIS. However, Baghdadi's claim was disconfirmed by Jowlani. A day after Baghdadi’s statement, Jowlani rejected the merger and affirmed the group's allegiance to al-Qaeda and its

Safavid" alliance referred to the alliance between the "allied forces" and the post-Saddam Shiite-led Iraqi government. The Sunni insurgency primarily termed the Shiite-dominated Iraqi government, the Safawi rule ${ }_{660}$ Zeina Karam and Qassim Abdul-Zahra, "Al Qaeda's Nusra Front Leader Stays in Syria Shadows," The National, November 4, 2013 (http://www.thenational.ae/world/middle-east/al-qaedas-nusra-front-leader-stays-in-syriasshadows).

${ }^{661}$ Rania Abouzeid, “The Jihad Next Door: The Syrian Roots of Iraq's Newest Civil War,” Politico, June 23, 2014 (http://www.politico.com/magazine/story/2014/06/al-qaeda-iraq-syria-108214).

${ }^{662}$ Lister, "Profiling the Islamic State," 12.

${ }^{663}$ Ibid.

${ }^{664}$ Ibid., 13.

${ }^{665} \mathrm{Ibid}$.; Al-Sham is a region often compared with the Levant or Greater Syria, the group adopted the name of Islamic State of Iraq and al-Sham (ISIS) or Islamic State of Iraq and the Levant (ISIL). See Faisal Irshad, "Isis, Isil, IS, or Daesh? One group, many names," BBC Monitoring, December 2, 2015 (http://www.bbc.com/news/worldmiddle-east-27994277). 
leader, Zawahiri. ${ }^{666} \mathrm{JN}$ subsequently split, with some members, particularly foreign fighters, remaining with ISIS. ${ }^{667}$ Jowlanis' faction of $\mathrm{JN}$ turned into the al-Qaeda faction in Syria. Therefore, ISIS reestablished itself as a component of the Syrian conflict, subsequently declaring its de facto capital the city of Raqqa in northeast Syria. ${ }^{668}$

Immediately after opening a new front in Syria, ISIS separated its approach from other SJGs, including JN and even al-Qaeda. While JN shared power and governance with other Syrian parties, ISIS demanded complete control over society. ${ }^{669}$ ISIS's July 2013 killing of a senior Free Syrian Army commander in Latakia was a major signal to other jihadi and insurgent groups that it did not have any intention to join any coalition. Therefore, in January 2014, a coalition of “moderate groups," including Free Syrian Army, Mujahidin Army, Syrian Revolutionaries Front, and the Islamic Front ${ }^{670}$ launched operations against ISIS across northern Syria which resulted in their withdrawal to the east in March 2014. ${ }^{671}$ ISIS's refusal to submit to al-Qaeda-appointed mediators pushed the leader of al-Qaeda, Zawahiri, to announce in February 2014 the following: "ISIS is not a branch of al-Qaeda, we have no organizational relationship with it, and al-Qaeda is not responsible for ISIS's actions." ${ }^{972}$ This announcement meant al-Qaeda's formal separation from ISIS, and the recognition of the latter as an independent jihadi organization. Following the separation from al-Qaeda, ISIS remained the most effective SJG in Iraq and Syria, managing numerous land operations and suicide attacks in the Middle East and beyond.

\footnotetext{
${ }^{666}$ Abouzeid, "The Jihad Next Door.

${ }^{667}$ Ibid.; Richard Spencer, "Syria: Jabhat al-Nusra Split After leader's Pledge of suppoart for al-Qaeda," The

Telegraph May 19, 2013; "Iraqi Al-Qaeda Chief Rejects Zawahiri orders," Al-Jazeera, June 15, 2013

(http://www.aljazeera.com/news/middleeast/2013/06/2013615172217827810.html)

${ }^{668}$ Lister, "Profiling the Islamic State," 13.

${ }^{669}$ Ibid.

${ }^{670}$ Erika Solomon, "Factbox: Syria's rebel groups," Reuters, January 9, 2014 (http://www.reuters.com/article/ussyria-crisis-rebels-factbox-idUSBREA080SW20140109).

${ }^{671}$ Lister, "Profiling the Islamic State," 13.

${ }^{672}$ Ibid.
} 
ISIS's overall three-year complex and multilateral campaign from early 2011 to mid-2014 was extremely consequential for the group's dramatic growth into an organization capable of conquering and governing territory beyond nation-state boundaries and extending its recruitment networks in Muslim communities throughout the globe. In order to propagate its accomplishment and goal, as well as to attract a wider audience, ISIS issued a series of coordinated media releases in 2014. The most significant of these was a 34-minute audio speech in Arabic, entitled "This is the Promise of Allah," which was posted on the Twitter account of the group's al-Itisaam Media Foundation on June 29,2014, the first day of the Islamic holy month of Ramadan. The speech announced ISIS's rebranding as the 'Islamic State,' (IS) ${ }^{673}$ The speech was translated, simultaneously, into English, French, German, and Russian by IS's al-Hayat Media Center. Through this audio, which is known as the "Declaration of IS," the group's spokesman Abu Muhammad al-Adnani (Taha Subhi Falaha) announced the formal establishment of an Islamic State under the leadership of Ibrahim Awwad Ibrahim Ali al-Badri al-Samarra'iyy (Abu-Bakr alBaghdadi) introducing him as Caliph Ibrahim:

“...he [Baghdadi] has accepted the baya (pledge of allegiance). Thus, he is the imam and caliph for the Muslims everywhere. Accordingly, the 'Iraq and Sham' in the name of the Islamic State is henceforth removed from all official deliberations and communications, and the official name is the Islamic State from the date of this declaration. The legality of all emirates, groups, states, and organizations becomes

\footnotetext{
${ }^{673}$ Abu Muhammad Al-Adnani Al-Shami, "This is the Promise of Allah," Institutional Scholarship, June 19, 2014 (https://scholarship.tricolib.brynmawr.edu/bitstream/handle/10066/14242/ADN20140629.pdf?sequence=1); see also Matt Bradley, "ISIS Declares New Islamist Caliphate,” Wall Street Journal, June 29, 2014 (http://www.wsj.com/articles/isis-declares-new-islamist-caliphate-1404065263).
} 
null by the expansion of caliphate's authority and the arrival of its troops to their areas. ${ }^{\circ 74}$

According to the speech, Baghdadi's Islamic State would look like a "Sharia-based Islamist Caliphate," the core of the Salafi-Jihadi ideology. ${ }^{675}$ In addition to "This is the Promise of Allah," IS's 'fundamentalism' was expressed in other statements including the "Khilafah Declaration" and the group's formal ceremonies and behavior. ${ }^{676}$ The two founding declarations, in particular, largely using quotes from the Salafi scholars and the earliest Muslim leaders and caliphs, justify the need for the establishment of a transnational Sharia-based caliphate over the Muslim world. Also in practice, IS leadership made enormous efforts to duplicate the political arrangements, activities, and behavior of the early caliphs. For example, Baghdadi's designation sermon as the Amir al-Muminin, 'the Commander of the Faithful,' was a clear duplication of the designation of the first Muslim Caliph, Abu Bakr in 632. On the first day of Ramadan, all participants of a Friday sermon in Mosul's Great Mosque pledged their allegiance (baya) to Baghdadi. ${ }^{677}$ Then the Caliph, taking the exact words from Abu Bakr, admitted the position: "Obey me, as I obey God and his Prophet. If I do not obey God and his Prophet, you do not have to obey me." ${ }^{978}$

Tracing IS's evolution from a number of personally motivated individuals for revenge and fights back to the establishment of a Salafi-jihadi group with global ambitions indicates the complexity of the origins of IS. This requires investigating the causes of the formation of this organization from the individual to the international levels. Moreover, since IS developed in the political and security vacuum produced by state-fragility in post-Saddam Iraq, it is necessary to

\footnotetext{
${ }^{674}$ Al-Adnani Al-Shami, "This is the Promise of Allah."

${ }^{675}$ Belen Soage, "Introduction to Political Islam," 17.

${ }^{676}$ See Rosiny, "The Rise and Demise of the IS Caliphate," 100; "ISIS Spokesman Declares Caliphate, Rebrands Group as 'Islamic State;" "Khilaphah Declaration," Dabiq, Issue 1 (Ramadan 1435/Summer 2014): 3-10 (http://media.clarionproject.org/files/09-2014/isis-isil-islamic-state-magazine-Issue-1-the-return-of-khilafah.pdf). ${ }^{677}$ Rosiny, "The Rise and Demise of the IS Caliphate," 100.

${ }^{678}$ Ibid.
} 
examine those conditions within the state-fragility framework. Hence, the remainder of this chapter examines multiple root causes of the emergence of IS at the individual, group, and international levels of analysis by drawing on the 'levels of analysis' framework. The following chapter investigates the state fragility conditions in post-Saddam Iraq which magnified the relationship between those causes and the emergence of IS.

\section{Individual Level}

Most jihadi leaders and combatants who established AQI in 2004 were former al-Qaeda and JTJ members and younger international jihadis who escaped the US invasion of Afghanistan in $2001{ }^{679}$ Following the US invasion of Afghanistan, Al-Qaeda divided into 'core al-Qaeda,' based in Pakistan, and its affiliated groups in at least 16 Muslim countries, from Iraq to Mali to Yemen. ${ }^{680}$ These jihadis initially formed several al-Qaeda affiliated groups, one of which was AQI led by Zarqawi. ${ }^{681}$ Overall, there are at least three individual-level factors that were significantly effective in the process of the formation of AQI and its development to IS. First, personal security concerns among individual jihadis and Iraqi Baathists who following the US invasions of Afghanistan and Iraq were in search for a safe haven in order to escape an expected prosecution. Second, a personal desire to resist the US invasion in Iraq among jihadis and Baathists. Finally, since the jihadis believed resistance in Iraq would put them in a direct confrontation with the sole great power, a 'quest for significance,' or a sense of glory was a third factor at this level of analysis which motivated individual jihadi combatants toward the formation of IS.

\footnotetext{
${ }^{679}$ Lauren B. O’Brien, “The Evolution of Terrorism Since 9/11,” FBI Law Enforcement Bureau, September 2011 (https://leb.fbi.gov/2011/september/the-evolution-of-terrorism-since-9-11).

${ }^{680}$ TY Mccormick, “Al-Qaeda Core: A Short History,” Foreign Policy, March 17, 2014 (http://foreignpolicy.com/2014/03/17/al-qaeda-core-a-short-history/).

${ }^{681}$ O’Brien, "The Evolution of Terrorism since 9/11."
} 
Following the American invasion of Afghanistan and the escape of al-Qaeda core from this country, thousands of motivated individual jihadis spread all over the Middle East. These individuals were blacklisted by the US and its allies as highly wanted terrorists. Hence, finding a safe haven was one of the top priorities of those individual jihadis immediately after $9 / 11$. Zarqawi and his JTJ operatives were among thousands of international jihadis who left Afghanistan and subsequently infiltrated into other Muslim countries in search of sanctuaries. The US invasion of Iraq in 2003 and the subsequent collapse of the Iraqi state produced ungoverned borders and territories in Iraq which facilitated the interaction and reorganization of these individuals within Iraq. In search of a safe haven, these jihadis ended up in Iraq, where they could reorganize, create new groups, and/or incorporate in other like-minded organizations. In addition to the jihadis, the US invasion of Iraq led to a process of de-Baathification of the Iraqi state which put ex-Baathists on the same track as jihadis, searching for a safe haven in order to escape the expected prosecution.

Following the US invasion of Iraq and in order to prevent the expansion of insurgency and facilitate the transformation of power to a democratically elected Iraqi government, the United States created an administration in Baghdad called the Coalition Provisional Authority (CPA) which would rule Iraq directly. Shortly after coming to existence, the CPA planned a policy which included disbanding the Iraqi military and civil services and giving power to the Shiites with the cost of alienating the well-trained Sunni state administrators. This policy, which was basically informed by the de-Nazification of the post-Hitler Germany, was branded de-Baathification. The policy forced hundreds of thousands of Sunni Iraqis from the civil and military administrations into unemployment. ${ }^{62}$

\footnotetext{
${ }^{682}$ Peter Galbraith, The End of Iraq: How Americans Incompetence Created a War Without End? (New York: Simon \&Schuster, 2006), 119.
} 
The de-Baathification was a policy designed by American administrators into two orders: Coalition Provisional Authority Order 1 (CPAO1), and Coalition Provisional Authority Order 2 (CPAO2). Less than a month after the establishment of the CPA in April 2003, which took over the rebuilding of Iraq from the Office for Reconstruction and Humanitarian Assistance, the CPA administrator, Paul Bremer, released CPAO1 which is known as the 'de-Baathification of Iraqi Society. ${ }^{683}$ The document ordered the elimination of senior Baath party members from "any position of civil service." Senior members were considered as those who were identified with the top 4 levels of the former Baathist party who worked as group, section, branch and regional command leaders. ${ }^{684}$. The Order also banned the targeted individuals from future service in the private sector. ${ }^{685}$ As a result, CPAO1 drove some 85,000 to 100,000 people from government jobs who in Bremer's eyes were 'true believers' and adherents to Saddam's regime. ${ }^{686}$ The CPA's second order (CPAO2), or the 'Dissolution of Entities,' was issued to dissolve all defense, intelligence and related organizations within the Iraqi government. In practice, its purpose was to disband the Iraqi Army which included the Republican Guard, Navy and Air Force, and to dissolve the Defense and Information Ministries. ${ }^{687}$ The policy threw an estimated 350,000 to 400,000

\footnotetext{
683 Coalition Provisional Authority. Order 1: DeBaathification of Iraqi Society. 2003; Cherish M. Zinn, “Consequences of Iraqi De-Baathification,” Cornell International Affairs Review 11(2), 2016: 2-3.

${ }^{684}$ Zinn, "Consequences of Iraqi De-Baathification," 3.

685 Ibid.

${ }^{686}$ Pfiffner, "US Blunders in Iraq: De-Baathification and Disbanding the Army, 79; Alissa, j. Rubin, "Ahmad Chalabi and the Legacy of de-Baathification in Iraq," The New York Times, Nov. 3, 2015 (http://www.nytimes.com/2015/11/04/world/middleeast/ahmad-chalabi-and-the-legacy-of-de-baathification-iniraq.html); James, P. Pfiffner, "US Blunders in Iraq: De-Baathification and Disbanding the Army," Intellegence and National Security 25(1), 2010: 78; Paul Bremer, My Year in Iraq (New York: Simon and Schuster 2007), 39; Thomas Ricks, Fiasco: The American Military Adventure in Iraq (New York: Penguin Press 2006), 160.

${ }^{687}$ Coalition Provisional Authority. Order 2: Dissolution of Entities with Annex A. 2003; Zinn, "Consequences of Iraqi De-Baathification," 3; Bob Woodward, State of Denial: Bosh at War, Part III, (New York: Simon \&Schuster, 2006), 194-195; Jane Arraf, “U.S. Dissolves Iraqi Army, Defense and Information Ministries,” CNN, May 23, 2003 (http://www.cnn.com/2003/WORLD/meast/05/23/sprj.nitop.army.dissolve/).

Sebastian Usher, "Baathist Mistakes Corrected Amid Concern," BBC News, January 12, 2008 (http://news.bbc.co.uk/2/hi/middle east/7185276.stm).
} 
former Iraqi officers and soldiers out of work, as well as an estimated 2,000 Information Ministry employees. ${ }^{688}$ These former soldiers felt humiliated and were desperate to locate some form of income to support their families. ${ }^{689}$ In addition to massive unemployment in both civil and military sectors, the de-Baathification policy carried a huge political consequence, almost completely excluding Sunnis from Iraq's political landscape. By contrast the order paved the way for Shiites and Kurds to replace Sunni Arabs in post-Saddam Iraqi politics. ${ }^{690}$ Therefore, the Iraqi Sunnis' concern about being discriminated against and coming under constant attack by Shiite communities and the Shiite-controlled security forces was real. For example, Sunnis living in Baghdad were driven out of much of the city by Shiite-controlled security forces in 2006 and 2007. ${ }^{691}$ According to a US embassy cable in September 2007: "Sunnis have largely fled to outlying areas [of Baghdad] or have been concentrated into small enclaves surrounded by Shia neighborhoods. ${ }^{\circ 92}$

Taken together, the first root cause of the emergence of the Iraqi insurgency at the individual level of analysis, which ultimately developed into IS, can be traced in the post-US invasions of Afghanistan and Iraq which led to the securitization of jihadis and discrimination against Baathists - a process that led to the infiltration of international jihadis into Iraq's ungoverned areas and the emergence of domestic insurgency by Iraqi Baathists and Islamists who were discriminated against and expected prosecution in the post-Saddam political process of Iraq.

\footnotetext{
${ }^{688}$ Woodward, State of Denial: Bosh at War, Part III, 194-195; Arraf, "U.S. Dissolves Iraqi Army, Defense and Information Ministries;" Usher, "Baathist Mistakes Corrected Amid Concern."

${ }^{689}$ Zinn, "Consequences of Iraqi De-Baathification, 3.

${ }^{690}$ Liz Sly, "The Hidden Hand Behind the Islamic State Militias? Saddam Hussein's," The Washington Post, April 04, 2015 (https://www.washingtonpost.com/world/middle east/the-hidden-hand-behind-the-islamic-state-militantssaddam-husseins/2015/04/04/aa97676c-cc32-11e4-8730-4f473416e759_story.html).

Tom Porter, "ISIS: Five U.S. Mistakes Which Led to the Rise of Islamic State," International Business Times, June 11, 2015 (http://www.ibtimes.co.uk/isis-five-us-mistakes-which-led-rise-islamic-state-1505642).

${ }^{691}$ Patrick Cockburn, The Rise of Islamic State: ISIS and the New Sunni Revolution, (London and New York: Verso, 2014), 70 .

${ }^{692}$ Cockburn, The Rise of Islamic State 70.
} 
The wanted jihadis and discriminated Baathists became highly prone to interact and cooperate for achieving the common goal of personal security, survival, and revenge. These individuals either joined the internationally active SJGs such al-Qaeda and its offshoots or formed militant organizations of their own. ${ }^{693}$ IS was the outcome of interaction among these groups and their development toward a uniform organization under a sense-making ideology. According to an International Crisis Group report, the emergence of IS [as an anti-Shiite and anti-American SJG] became inevitable because: "Sunnis saw their only chance of surviving in Iraq was to fight as Sunnis against a US-sponsored Shiite-led government. ${ }^{" 694}$ Findings show that after the formal launching of Islamic State under a self-declared Caliph in 2014, the IS leadership was mainly dominated by Salafi-jihadis and former Iraqi Generals. In addition to jihadi figures at the top, IS maintained 1,000 "medium-and-top-level field commanders of the very Iraqi army which was disbanded by Americans." Baghdadi’s both immediate deputies were former ranking officers in the Iraq military. Abu Ali al-Anbari, the chief of Syria operations, was a major general in the Iraqi Army, and Fadl Ahmad Abdullah al-Hiyali, the chief of Iraq operations, was a lieutenant colonel in Iraq Military Intelligence and a former officer in the Iraqi Special Forces. ${ }^{695}$ Moreover, two of the four members of IS's military council (Abu Aiman al-Iraqi, and Abu Ahmad al-Alwani) were former officers in the Iraqi Army. ${ }^{696}$

The second and most significant individual-level cause of the emergence of IS was a sense of revenge among both Islamists and Baathists. All Iraq-based jihadi and insurgent groups' leaders

\footnotetext{
${ }^{693}$ Flibbert, "The Consequences of Forced State Failure in Iraq," 69.

${ }^{694}$ Cockburn, The Rise of Islamic State, 69.

${ }^{695}$ Lister, The Islamic State: A Brief Story, 35; 76-77; Ruth Sherlock, "Inside the leadership of Islamic State: How the New 'Caliphate' is Run," The Telegraph, July, 9, 2014

(http://www.telegraph.co.uk/news/worldnews/middleeast/iraq/10956280/Inside-the-leadership-of-Islamic-Statehow-the-new-caliphate-is-run.html).

696 "Exclusive: Top ISIS Leaders Revealed," Al-Arabia News, February 13, 2014

(http://english.alarabiya.net/en/News/2014/02/13/Exclusive-Top-ISIS-leaders-revealed.html).
} 
and operatives, before they were organized in group levels in Iraq, were individually motivated to revenge the 'Muslim's oppression' by the US and its domestic adversaries. Bin Laden personally called upon every jihadi to revenge the invasion of Iraq by conducting attacks against members of the Coalition forces in Iraq. Zarqawi added Shiites in the list of his targets, calling upon his followers to target the 'global oppressor' and its 'domestic compromisor,' the Shiites. Accordingly, AQI developed a strategy which targeted both the external occupation and the internal transition by routinely carrying out attacks on both American and Shiites ${ }^{697}$ All members of AQI and other Iraq-based jihadi and insurgent groups in the early years following the invasion were driven by anger because their land was invaded by a non-Muslim power and their power was taken by Shiites. IS's declarations and its official documents indicate the significant role of revenge in the formation of this organization. IS leadership labelled its anti-American campaign as a "retaliatory war" and the Dabiq, IS's official magazine considers the killing of Americans and non-Muslims, including civilians, as a revenge campaign:

"Therefore, the Islamic State leadership decided to target the Catholic Christians of Baghdad so as to teach the toghut of the Copts that the price of Muslim blood is costly and so accordingly, if his church persecuted any Muslim in Egypt, he would be directly responsible for every single Christian killed anywhere in the world when the Islamic State sought it is just revenge..." ${ }^{998}$

Finally, the exclusion of Sunnis, particularly the well-trained Baathists, from political, economic and social power in Iraq directed them toward a fight back and establishment of "resistance" groups. Following the defeat of Saddam's regime, the Sunnis had lost power, jobs, and political influence to a Shiite-led government, mainly because of the foreign invasion and its support of

\footnotetext{
${ }^{697}$ O’Brien, "The Evolution of Terrorism since 9/11."

698 "Revenge for the Muslimat Persecuted," Dabiq 7 (January/February 2015) 31-32.
} 
anti-Baathist process. The foreign power that imposed the status quo was the sole great power in a unipolar international system, or the remaining Superpower, direct confrontation against which was a legitimizing point in the jihadis' apocalyptic campaign. The international jihadis that mainly led the Iraq-based insurgency propagated this idea as a winning point among all elements of the post-invasion Iraqi insurgency. The idea greatly motivated and organized a "resistance" which Zarqawi described as an anti-Sunni "Crusader-Safawid alliance" in Iraq. Thus, in addition to security and revenge, 'glory' through fighting the sole great power and its domestic ally for "restoring the honor" was a determinant factor of the development of IS at individual level of analysis. Revenge was probably the most significant stimulus among oppressed Iraqi Sunnis for creating an IS-type SJG, but it was a sense of glory that drove jihadis of different origins to join IS for fighting 'the last battle' and defending their "oppressed coreligionists." As Abu Dujana, a British IS fighter remarks “... Helping the oppressed is better than having a red [European] passport. ${ }^{~} 699$

\section{Group Level: Salafi-Jihadism}

Salafi-Jihadism is IS's source of unity and a key factor that brought together various jihadi and Baathist groups under a uniform organization. This ideology not only motivated international jihadis toward the formation of Islamic State but also allowed for the incorporation of likeminded individuals and groups that initially emerged with different motivations in a transnational jihadi organization like IS. Salafi-jihadism, in this sense, functioned as a cause, a framework, and a unifying mechanism which led the process of insurgency development in Iraq in a specific direction that eventually resulted in the formation of IS. IS, like al-Qaeda, follows the Islamist goal

${ }^{699}$ Lister, The Islamic State: A Brief Introduction, 60. 
of establishing an Islamic caliphate, however, it does so with greater severity, different operational methods, and rhetoric. In contrast to al-Qaeda, Islamic State is absolutely uncompromising on doctrinal matters, prioritizing the promotion of an unforgiving strain of Salafi thought. But in principle, like bin-Ladenism, the IS ideology is the outcome of a marriage between the Saudi strain of Wahhabi conservatism and the Egyptian branch of 'militant' Salafism. Thus, the main difference between IS and al-Qaeda is not in ideology but in their different operational approach which is common among Islamist groups. As a jihadi leader stated: "the split [among the Islamist groups] is not in thought, it is in strategy.",700

IS's reliance on Jihadi-Salafism is initially attributed to Zarqawi who studied theology with the prominent Salafi scholar Abu Muhammad al-Maqdisi. ${ }^{701}$ Moreover, early IS leaders, Abu Umar al-Baghdadi, and Abu Hamza al-Muhajir were famous Salafi thinkers and activists. ${ }^{702}$ Their speeches drew extensively on established Islamist authorities, many of them from the Wahhabi tradition. ${ }^{703}$ The first official spokesman of IS, Abu Muhammad al-Adnani, even taught the writings of Muhammad Ibn Abd al-Wahhab to fellow jihadis. ${ }^{704}$ IS's official publications are little more than quotations from early Salafi scholars and activists. The two founding declarations of IS, "This is the Promise of Allah" and the "Khilafah Declaration," are two main examples that reflect the Salafi doctrine. The group's ideology and its severe operational method have its origins in Zarqawi's worldview. In a 2003 statement, then the JTJ leader, Zarqawi articulated his project in a framework that incorporated all major elements of the Salafi-jihadi ideology including the

\footnotetext{
${ }^{700}$ Quintan Wiktorowicz, “Anatomy of the Salafi Movement”, Studies in Conflict and Terrorism 29, $2006: 208$.

${ }^{701}$ Bunzel, "From Paper State to Caliphate: the Ideology of the Islamic State," 9-10.

702 Ibid., 10.

703 Ibid.

704 Ibid.
} 
definition of a problem, an enemy, a method, and an ultimate goal. The statement was quoted repeatedly in IS declarations:

"We will fight in the cause of God until His sharia prevails. The first step is to expel the enemy and establish the state of Islam. We would then go forth to reconquer the Muslim lands and restore them to the Muslim nation...I swear by God that even if the Americans had not invaded our lands together with the Jews, the Muslims would still be required not to refrain from jihad but go forth and seek the enemy until only God Almighty's sharia prevailed everywhere in the world...Our political project is to expel this marauding enemy. This is the first step. Afterward, our goal is to establish God's sharia all over the globe." 705

Thus, Zarqawi highlights the American alliance with the Jews and their invasion of Muslim lands as the problem, the United States as the enemy, Jihad as the method, and the establishment of an Islamic state which would dominate the globe as his ultimate goal. Elements of Salafi-Jihadism can be observed also in IS's all founding declarations and statements. Furthermore, in order to propagate its "fundamentalist" commitment to ideology, the group even assimilated its organizational development to early Islamic instances and methods. For example, in 2010 ISI adopted a strategic shift initiating an information campaign aimed at re-emphasizing the legitimacy of their Islamic state project. One facet of this campaign was to "stress Abu Omar al-Baghdadi's alleged membership of the Quraysh tribe, which according to the early Islamic tradition would produce the next caliph." ${ }^{, 706}$ Prophet Mohamed himself was a member of the Quraysh tribe and the two greatest Islamic empires, Umayyad and Abbasid caliphates that claimed authority over the

\footnotetext{
${ }^{705}$ Hashim, "From Al-Qaeda Affiliate to the Rise the Islamic Caliphate," 4; "Translation of Old Al-Zarqawi Interview, Says God's Law Must Rule 'Entire World," Jihadist Websites-Open Source Report, December 06, 2006, Open Source Center (https://opensource.gov/portal/server.pt/gateway/PTARGS $0 \quad 0 \quad 5766 \quad 972 \quad 0 \quad 43 / \mathrm{htt}$ ).

${ }^{706}$ Lister, "Profiling the Islamic State," 11.
} 
Muslim world from the mid- $7^{\text {th }}$ to the early $16^{\text {th }}$ century represented the two branches of the tribe. Baghdadi was killed on April 18, 2010 and his successor, Abu Bakr al-Baghdadi, is also allegedly a member of Quraysh tribe. ${ }^{707}$ Another similarity is the designation sermon of IS's leader. Baghdadi's designation sermon as the Amir al-Muminin, was precisely the same as the designation of the first Muslim Caliph Abu Bakr in $632 .{ }^{708}$ Holding the symbolic sermon, the founders of IS attempted to assert both their ideological and practical intention to return to the fundamentals of Islam, which is one of the main pillars of Islamism. In another event, on July 1, 2014, Baghdadi stated: "O Muslims in all places, who is able to immigrate to the Islamic State, let him emigrate. Emigration to the Abode of Islam is obligatory." ${ }^{" 709}$ The call was identical to the example of the Prophet when he left Mecca for Medina [in 622] and established the Abode of Islam. Iraq-based jihadi leaders, following the announcement of the formation of ISI in in October 2006, claimed even "the territories [under our control] equal in expense to the first state in Medina.""110

Taken together, IS embraces Salafi-Jihadism's four basic elements which include defining a problem, an enemy that causes the problem, a military approach to resolving it, and an ultimate goal. These elements are well-explained in Islamic State's founding documents, particularly in 'This is the Promise of Allah' and the "Khilafah Declaration." The following table makes the elements of IS's ideology clearer.

\begin{tabular}{ll}
\hline The Problem & The American Invasion of Muslim lands \\
\hline The Enemy & Safavid-Crusader Alliance \\
\hline The Method & Jihad Against Near \& Far enemy \\
\hline The Goal & Creating an Islamic Caliphate
\end{tabular}

\footnotetext{
${ }^{707}$ Brian Fishman, "Redefining the Islamic State: The Rise and Fall of Al-Qaeda in Iraq," National Security Studies Program Policy Paper, New America Foundation (August 2011): 11-12 (https://static.newamerica.org/attachments/4343-redefining-the-islamicstate/Fishman_Al_Qaeda_In_Iraq.023ac20877a64488b2b791cd7e313955.pdf).

${ }^{708}$ Rosiny, "The Rise and Demise of the IS Caliphate," 100.

${ }^{709}$ Abu Bakr al-Baghdadi, "Tafrigh al-Kalimat al-Sawtiat: Risalat ilal-Mujahedeen wal-Ummat al-Islamiat fi Shar Ramadan,” Al-Battar Media Foundation, July 1, 2014 (https://archive.org/download/K_R_abubkr/et34.pdf).

${ }^{710}$ Bunzel, "From Paper State to Caliphate: the Ideology of the Islamic State,"
} 
"This is the Promise of Allah" describes the oppression of Muslims and the invasion of their lands by Americans and their far and near allies (particularly Shiites) as the existing problem of the Muslim world. Likewise, the declaration defines the infidel nations of the West as the enemy; it considers jihad as the method to fight the enemy and resolve the problem. And finally, the declaration regards the expansion of a 'sharia-based' Islamic State over the Muslim lands as its ultimate political goal and call on all jihadi factions throughout the globe to pledge allegiance to the Islamic State:

“...For by fulfilling this condition [Allah's promise] comes the ability to... remove oppression, spread justice, and bring about safety and tranquility... We were patient for years in the face of being killed, imprisoned, having our bones broken and our limbs severed. We drank all sorts of bitterness, dreaming of this day... O soldiers of the Islamic State, then congratulations to you... Today the "illegitimates" in the east and west are frightened. Today the nations of infidels in the west are terrified... Now the caliphate has returned, humbling the necks of the enemy... They [the enemy] never recognized the Islamic State, to begin with. Although America, Britain, and France acknowledge its existence. And if they tell you, we do not accept your authority. Then say to them, we had the ability to establish the caliphate... The State will remain, by Allah's permission... O soldiers of the Islamic State, Allah ordered us with jihad and promised us with victory... you will be facing fierce battles that cause the children's hair to become gray... It is time for you to end this abhorrent partisanship, dispersion, and division, for this condition, is not from the religion of Allah at all. The legality of all emirates, groups, states, and organizations becomes null by the expansion of the caliphate authority and 
arrival of its troops to their areas. So rush O Muslims and gather around your caliphate, so that you may return as you once were for ages, kings of the earth and knights of war. By Allah, if you disbelieve in democracy, secularism, nationalism, as well as all the other garbage and ideas from the west, and rush to your religion and creed, then by Allah, you will own the earth, and the east and west will submit to you. ${ }^{711}$

In addition to the above general declaration of its ideology, IS has stated Salafi-Jihadism as its founding ideology more explicitly in its official magazine in English, Dabiq. Dabiq's first issue, referencing dozens of Islamic texts, earliest Muslim scholars, Salafi leaders, caliphs, the Prophet's companions and some contemporary popular Islamists, describes concretely the "crusader armies" suppressing Muslims as the problem, the non-Muslim world led by a Judeo-Crusade alliance as the enemy, Jihad as the method and the expansion of the Islamic State over the Muslim lands as the ultimate goal:

"The spark has been lit here in Iraq, and its heat will continue to intensify until it burns the crusader armies in Dabiq... O Ummah of Islam, indeed, the world today has been divided into two camps and two trenches, with no third camp present: the camp of the Muslims and the mujahidin everywhere, and the camp of the Jews, the Crusaders, their allies, and with them the rest of the nations and religions of disbelief, all being led by America and Russia, and being mobilized by the Jews... The sun of jihad has risen. The signs of victory have appeared... The goal of

\footnotetext{
711 “ISIS Spokesman Declares Caliphate, Rebrands Group as 'Islamic State.””
} 
establishing the Caliphate has always been one that occupied the hearts of the mujahideen since the revival of jihad in this century..."

The elements of IS's ideology and its historical symbolism are attractive in Sunni societies which help the group to attract young Muslims and expand both its recruitment and operational capabilities beyond Iraq and Syria. Although de-Baathification and the removal of thousands of Iraqi civil and military employees contributed to the development of AQI and ultimately IS Iraq, the group's ideology provides a wider room for fighters from all over the world to join it. SalafiJihadism in this sense provides IS with a transnational identity legitimizing its jihad in a global context. The Khilafah Declaration shows that an intense concentration on creating a transnational Islamic State is the backbone of the idea of IS. The declaration describes IS as a Caliphate that "gathers the Caucasian, Indian, Chinese, Shami, Iraqi, Yemeni, Egyptian, Maghribi (North African), American, French, German, and Australian." ${ }^{713}$

In addition to its contemporary transnationalism, which is a main pillar of the Salafi-jihadi ideology, IS drew on the works of main Salafi scholars from Ibn-Taymiyyah to Sheikh Abu-Bakr Naji which articulate the group's ideological scope. A few years before the formation of IS, Naji discussed in his work the need for the establishment and expansion of a transnational Caliphate through a global Jihad. He believed that in a world dominated by Crusaders, it would not be possible to create a proper Islamic state in a single country. Naji exemplified the Taliban government in Afghanistan as a failed experience of Islamizing a specific county stating that "Although a proper Islamic regime, [the Taliban] did not survive infidel attacks and opposition by

\footnotetext{
712 "Khilaphah Declaration;" and "From Hijrah to Khilafah,” Dabiq, Issue 1 (Ramadan 1435): 33 (http://media.clarionproject.org/files/09-2014/isis-isil-islamic-state-magazine-Issue-1-the-return-of-khilafah.pdf). 713 "Khilaphah Declaration."
} 
Afghan elements." ${ }^{" 714}$ Therefore, the Islamic movement, according to Naji, must become global, fight everywhere, all the time, and on all fronts. ${ }^{715}$ Naji expected the neo-jihadis to create an "archipelago of wildernesses" in non-Muslim countries, especially in the West, turning them into parallel societies alongside existing ones:

"No one should feel safe without submitting, and those who refuse to submit must pay a high price. The aim of our movement is to turn the world into a series of wilderness in which only those under our rule enjoy security." 716

Naji's theory was built on the concept of terror as the main organizing principle of the "ministates" he hoped to set up in preparation for the coming caliphate. ${ }^{717}$ IS operationalized all of Naji's ideas in terms of globalizing terror, creating jihadi cells both in Muslim and in non-Muslim societies, and setting up wilayats or governorates as "mini-states" beyond Iraq and Syria. Therefore, IS's ideology is not a simple reliance on classical texts and early Islamic experiences. It incorporates original texts and early Islamic experiences and their modern interpretations by contemporary Salafis. Using this rigid ideology, IS formalized the Islamic State's status as the renascent caliphate in 2014 claiming authority over all Muslim societies and Islamist groups. The newly proclaimed caliphate called upon all Muslims throughout the world to pledge allegiance to Baghdadi as the caliph:

"We inform the Muslims that, with the announcement of the caliphate, it has become obligatory for all Muslims to give allegiance and support to Caliph Ibrahim, the void is the legitimacy of all emirates, groups, administrations, and

\footnotetext{
${ }^{714}$ Amer Taheri, "The jihadis' master plan to break us," New York Post, November 15, 2015 (http://nypost.com/2015/11/15/the-jihadis-master-plan-to-break-us/).

${ }^{715} \mathrm{Ibid}$.

${ }^{716}$ Ibid.

${ }^{717}$ Ibid.
} 
organizations to which his [i.e., Baghdadi's] authority extends and his army comes." 718

This statement was entirely justified by referencing original Islamic texts and messages by the Prophet and his companions and earlier Salafi scholars such Ibn Taymiyyah. Salafi-Jihadism's original caliphal vision, its historical idealism, and its transnational message will continuously provide IS and IS-like SJGs to expand and attract populations in all Muslim regions.

\section{International Level}

As discussed, Islamic State is not only about domestic politics or the Muslim affairs but it is also about international politics. It aims to establish a sharia-based Islamic State in the Middle East and extend it as the cornerstone of an alternative international order beyond. IS's internationalism is highlighted in the organization's official documents. Abu Maysara al-Iraqi, the chief spokesman of AQI, articulates the organization's primary goals as follows clearly indicating its multilateralism and international goals:

i. Remove the aggressor from Iraq.

ii. Affirm tawhid, the oneness of God, among Muslims.

iii. Propagate the message that 'there is no God but Allah', to all the countries in which Islam is absent.

iv. Wage jihad to liberate Muslim territories from infidels and apostates.

v. Fight the taghut, the idolatrous regimes, ruling Muslim lands.

vi. "Establish a wise Caliphate" in which the Sharia rules supreme as it did during the time of Prophet Mohammad.

718 “ISIS Spokesman Declares Caliphate, Rebrands Group as 'Islamic State.”' 
vii. Spread monotheism on earth, cleanse it of polytheism, to govern according to the laws of God... ${ }^{719}$

IS's international goal, the establishment of a sharia-based international order, is further bolded in all issues of Dabiq. Internationalism is probably the only subject Dabiq has not missed noting since its first publication in the summer of 2014. The organization's insistence on international goals has its origins in international-level causes that made the development of IS possible in the first place. The Iraq-based Salafi-jihadi and insurgent groups that transformed into IS emerged primarily as a reaction to an international 'problem,' the United States invasion of Iraq and its regional consequences.

At least four factors can be considered as the main cause of the emergence of IS at this level of analysis. First, the US invasion of Afghanistan, which led to the "migration" of thousands of transnational jihadis from Afghanistan seeking new sanctuaries and an opportunity to reorganize all around the Muslim world. Those individuals were under the US and its allies' surveillance and therefore searched for safe havens. Zarqawi and his JTJ is an example of those jihadis. Second, the US invasion of Iraq which put the ideologically inspired jihadis in a direct confrontation with the sole great power in the Middle East and its domestic ally, the Shiites. This direct confrontation motivated Salafi-jihadis to unify in a single 'united front' in the 'last battle' against the enemy. Thus developing an ideologically coherent and militarily mobilized organization against the US and its domestic ally in Iraq, the Shiite-dominated government, became both a religious duty and a strategic priority for jihadis which, in turn, provided the basis of unification between jihadis and Baathists. Third, the domestic consequences of the US invasion of Iraq, particularly, the infamous de-Baathification of Iraq's civil and military sectors that discriminated against Sunnis and pushed

\footnotetext{
${ }^{719}$ Ahmed S. Hashim, Iraq's Sunni Insurgency, Adelphi Paper No.402, International Institute for Strategic Studies, (London: Routledge, 2009), 34-35.
} 
them to join the newly emerged anti-American and anti-Shiite resistance in Iraq. And finally, the process of the formation of IS was facilitated by the regional consequences of the US invasion which resulted in a Cold War among regional powers, particularly Iran and Saudi Arabia, in Iraq. Historical accounts of the development of IS show that the most influential masterminds and founding members of AQI were jihadis who had fled Afghanistan after the US bombarded alQaeda and the Taliban in late 2001. Following the US invasion of Afghanistan, Al-Qaeda members and its affiliates fled the country, partly moving into Iraq. Zarqawi's JTJ was one of those groups that escaped Afghanistan, crossing Iran after a short stay in Biyara in the Kurdish province of Sulaymaniyah where the first anti-American invasion JTJ base established. ${ }^{720}$ Following the US invasion of Iraq JTJ moved to the Sunni Triangle from which it launched a series of attacks against American and Shiite targets. Zarqawi's increasing popularity among the Iraqi insurgency and his "brutal face" in Western media bought him the attention of bin Laden who finally gave him the alQaeda franchise in Iraq. The historical account of the evolution of IS shows that most of the transnational jihadis who primarily escaped the US invasion of Afghanistan slipped into Iraq after the US invasion of Iraq in 2003, forming or joining the anti-American and anti-Shiite SJGs. The US invasion of Iraq, in this sense, motivated direct confrontation making the formation of an antiAmerican 'united front' practically possible. Thus, the US invasions of Afghanistan and Iraq are two interconnected causal phenomena which eventually factored into the formation of the Iraqbased insurgency and its development into IS.

Moreover, Zarqawi's campaign of recruitment and expanding the anti-American jihad in Iraq benefited from the de-Bhaathification of Iraqi's military and civil services, a policy designed

\footnotetext{
${ }^{720}$ Joseph Felter and Brian Fishman "Al-Qaeda's Foreign Fighters in Iraq: A First Look at the Sinjar Records," Combating Terrorism Center, US Military Academy, (January 2, 2007): 4 https://www.ctc.usma.edu/posts/alqaidas-foreign-fighters-in-iraq-a-first-look-at-the-sinjar-records).
} 
by the American administrators in order to re-engineer Iraq's state. As a result, the Sunni minority was excluded from the Iraqi politics, hundreds of thousands of Sunnis being removed from the Iraqi Army and public services. Thus, the US invasion of Iraq which had motivated primarily jihadis of different origins to join the anti-American jihad in Iraq, pushed the discriminated and unemployed Iraqi Sunnis, scared of a Shia government, to join the anti-American and anti-Shiite Salafi-jihadi movement in Iraq. As a result, in addition to JTJ, five other Iraqi-based SJGs ${ }^{721}$ emerged mainly around international and domestic jihadis, ex-Bharathists, and younger Sunni militias. Those groups eventually merged with AQI in January 2006, forming Majlis Shura alMujahedeen (MSM), an umbrella organization which gradually transformed into ISI, ISIS, and IS. $^{722}$

Finally, the regional power struggle that divided the Middle East into Sunni vs. Shiite camps was decisive in the establishment of Iraq-based Sunni insurgency and its development to IS. Following the US invasion of Iraq in 2003, Iran emerged as the most influential regional power in Baghdad which was not pleasant to Saudi Arabia. A Shiite-dominated regime in Baghdad was not acceptable to Saudis because their doctrine of Wahhabism does not recognize Shiites as true Muslims. The increasing "Cold War" between Iran and Saudi Arabia significantly contributed to the polarization Iraq along Sunni-Shiite lines which is part of what allowed IS to rise in the Sunni part to fight for Sunnis in the sectarian Sunnis vs. Shiites war. ${ }^{723}$ Iran's intervention in Iraq by influencing Iraq's Shiite-led government and supporting the country's Shiite community is

\footnotetext{
${ }^{721}$ Namely, Jaish al-Ta'ifa al-Mansurah, Katbiyan Ansar Al-Tawhid wal Sunnah, Saray al-Jihad Group, al-Ghuraba Brigades, and al-Ahwal Brigades.

${ }^{722}$ Charles Lister, "Profiling the Islamic State," The Brookings Institute, Brookings Doha Center Analysis Papers 13 (November 2014), 8; Joseph Felter and Brian Fishman, "Al-Qaeda's Foreign Fighters in Iraq: A First Look at the Sinjar Records," Combating Terrorism Center at West Point, Harmony Project, January 5, 2008 (http://www.ctc.usma.edu/wp-content/uploads/2010/06/aqs-foreign-fighters-in-iraq.pdf).

${ }^{723}$ Gerges, ISIS: A History, 20; Max Fisher, "The Cold War Between Saudi Arabia and Iran that is Tearing the Middle East Apart, Explained”, Vox, June, 4, 2016 (http://www.vox.com/2016/1/4/10708682/sunni-shia-iran-saudiarabia-war).
} 
evident. Although there is no reliable evidence that proves the Saudi state's direct support of IS, the development of IS was significantly facilitated by a complicated network of Saudi Wahhabis with links to the country's intelligence service, and the region's Sunni states' intelligence networks. Evidence shows the anti-Shiite jihadi groups in Iraq and Syria obtained funds, arms, and religious cover from neighboring Sunni states, precious social and material capital that proved decisive. ${ }^{724}$ Thus, IS's development was facilitated by the geostrategic rivalry between Sunnidominated Arab states and Shia-led Iran and the group initially climbed on the shoulders of those states that battled each other for regional supremacy. ${ }^{725}$

Taken together, the root causes of IS at international level of analysis can be traced in three contexts: the US invasion of Afghanistan, the US invasion of Iraq, and the domestic and regional consequences of the two invasions. Motivated by the three international-level factors, thousands of Salafi-jihadis, regardless of their countries of origin united under a sense-making ideology to form an umbrella organization which would allow for launching a global jihad against the US and its allies. The umbrella organization, eventually, developed into IS.

In the beginning, the leadership of the Iraq-based SJGs, particularly ISI, ignored their transnational nature, especially connections with al-Qaeda affiliates. The data, however, proves the international nature of Iraq-based insurgency from its outset. ${ }^{726}$ According to data hundreds of foreign fighters infiltrated into Iraq as early as May 2003 - the number increased every year following the invasion and the emergence of insurgency. ${ }^{727}$ For example, in November 2007, the Combating Terrorism Center at West Point received nearly 700 records of foreign nationals that

\footnotetext{
${ }^{724}$ Gerges, ISIS: A History, 20.

${ }^{725}$ Ibid., 4; 20.

${ }^{726}$ Felter and Fishman "Al-Qaeda's Foreign Fighters in Iraq," 2.

${ }^{727}$ Ibid., 2.
} 
had entered Iraq between August 2006 and August 2007. ${ }^{728}$ The records contain "varying levels of information on each fighter, but often include the fighter's country of origin, hometown, age, occupation, the name of the fighter's recruiter, and even the route the fighter took to Iraq." ${ }^{\prime 29}$ According to those records, $41 \%$ of those individuals were Saudis, $18.8 \%$ Libyans, $8.2 \%$ Syrians, 8.1\% Yemenis, and 7.2\% Algerians. Moroccans accounted for $6.1 \%$ of the records and Jordanians $1.9 \% .{ }^{730}$ Most of the fighters entering Iraq listed their "work" istishhadi or martyrdom-seeker. ${ }^{731}$ As time passed, the number of foreign fighters in Iraq and Syria and, thus, the number of IS's foreign fighters increased. Studies indicate in 2014, around 15,000 foreign fighters from at least 90 countries were fighting in Iraq and Syria. ${ }^{732}$ According to another study in early 2015, 20,000 foreigners from 50 countries for which "sufficient data and/or reliable government estimates were available," had traveled to Iraq and Syria. ${ }^{733}$ IS's transnational structure and purpose can be observed in Baghdadi's abstract message, published in the first issue of the Dabiq:

"So let the world know that we are living today in a new era... The Muslims today have a loud, thundering statement, and possess heavy boots. They have a statement to make that will cause the world to hear and understand the meaning of terrorism, and boots that will trample the idol of nationalism, destroy the idol of democracy, and uncover its deviant nature." 734

\footnotetext{
${ }^{728}$ Felter and Fishman "Al-Qaeda's Foreign Fighters in Iraq," 2.

${ }^{729}$ Felter and Fishman "Al-Qaeda's Foreign Fighters in Iraq," 2.

${ }^{730}$ Felter and Fishman "Al-Qaeda's Foreign Fighters in Iraq," 7-8.

${ }^{731}$ Felter and Fishman "Al-Qaeda's Foreign Fighters in Iraq,"

${ }^{732}$ Lister, The Islamic State: A Brief Introduction, 59.

${ }^{733}$ Peter R. Neumann, "Foreign Fighter Total in Syria and Iraq now Exceed 20,000; Surpasses Afghanistan Conflict in the 1980s", ICSR, January, 26, 2015 (http://icsr.info/2015/01/foreign-fighter-total-syriairaq-now-exceeds-20000surpasses-afghanistan-conflict-1980s/).

${ }^{734}$ Abu Baker Baghdadi, “A New Era Has Arrived,” Dabiq 1 (Summer 2014), 10.
} 


\section{VI}

\section{State Fragility in post-Saddam Iraq and the Rise of IS}

This chapter investigates the role of state fragility in the post-Saddam Iraq as a necessary condition of the rise of IS. The finding shows that lack of legitimacy and weak authority were the most effective aspects of state fragility in post-Saddam Iraq which produced the conditions under which the Iraq-based anti-Shiite and anti-Coalition insurgency developed into IS. More specifically, poor political participation, sectarian politics and external intervention were the key factors that undermined the Shiite-dominated government's legitimacy, and lack of an effective and legitimate security and military apparatus weakened the state's authority in Iraq. These factors significantly contributed to the development of a condition under which IS was established. Lack of capacity, unlike in the case of al-Qaeda, played a marginal role in the establishment of IS. Iraq's early Sunni insurgent groups were composed of ex-Baathists and domestic and international jihadis. These groups underwent a process of interaction and integration leading to the formation IS. Empirical evidence shows that both the emergence of IS's forebears and the process of their development into IS were influinced by lack of legitimacy and lack of authority in Iraq.

Although the escalation of the degree of state fragility in the post-invasion period was unprecedented in Iraq, state fragility in this country is not a post-invasion phenomenon per se. Since its creation in 1921, the sovereign state of Iraq constantly faced internal and external challenges, however, it always maintained its political authority and monopoly over the use of force in its territory. In the 1990 s for instance, when state fragility due to a series of internal and external pressures increased, the state did not extensively lose its control, surveillance, and security 
capabilities. ${ }^{735}$ Rather, the Baathist regime was capable of maintaining the formal institutions of authority and the informal networks of patronage which, together, underpinned Saddam's rule. ${ }^{736}$ Therefore, the Coalition initially planned to seize the strong institutions of Saddam's state and use them to re-impose order in a post-Saddam situation. ${ }^{737}$ However, unlike the Coalition's prediction, the Iraqi state entirely collapsed immediately after the removal of Saddam which had both domestic and international consequences. Internally, it resulted in widespread civil disorder, insecurity, violence, looting, and the expansion of numerous rebel and insurgent groups. ${ }^{738}$ Externally, it forced US policy-makers to change their post-war strategy of 'reforming' a supposedly functioning state into rebuilding an entirely collapsed one. ${ }^{739}$

State collapse forced the US to replace the Office for Reconstruction and Humanitarian Assistance (ORHA) into the Coalition Provisional Authority (CPA) only one month after the invasion. ORHA was created on the basis of America's initial plan of reforming a functioning state and the belief that the Iraqi administration would remain and the Coalition would only assist it to reconstruct it. But when the prediction failed, the US created CPA based on the fact that there was

\footnotetext{
${ }^{735}$ Main factors that weakened the Iraqi state in the 1990s were both internal and external. Internally, the gradual erosion of state-society relations with the Sunni-led state increasingly exercising authority by coercion, fatally decreased the state's already poor legitimacy. Externally, the Iran-Iraq war (1980-1988), the Gulf War (1990-1991) and the U.N. sanctions (1990s) dramatically reduced the Iraqi state's capacity. See Toby Dodge, "Iraqi Transitions: From Regime Change to State Collapse," Third World Quarterly, 26(4/5), 2005: 709.

${ }^{736}$ Dodge, "Iraqi Transitions," 709-710; see also Michael R. Gordon, "Conflict in Iraq: Road to War; The Strategy to Secure Iraq Did not Foresees a Second War," The New York Times, October 19, 2004

(http://www.nytimes.com/2004/10/19/washington/the-conflict-in-iraq-road-to-war-the-strategy-to-secure-iraqdid.html? $\mathrm{r}=0$ ).

${ }^{737}$ Dodge, "Iraqi Transitions," 709-710; Gordon, "Conflict in Iraq."

${ }^{738}$ Gareth Stansfield, Iraq: People, History, Politics (Malden: Polity Press, 2007), 198; Adeed Dawisha, Iraq: A

Political History From Independence to Occupation (Princeton and Oxford: Princeton University Press, 2009), 241245, 262.

739 James Dobbins, Seth G. Jones, Benjamin Runkle, Siddharth Mohandas, Occupying Iraq: The History of the Coalition Provisional Authority (Santa Monica, Arlington, Pittsburgh: RAND, 2009); Eric Herring and Glen Rangwala, Iraq in Fragments: The Occupation and Its Legacy (Ithaca, New York: Cornell University Press: 2006), 13-16.
} 
no Iraqi state establishment in place following the invasion. ${ }^{740}$ Thus, with the creation of CPA, the Coalition planned to lay out a new vision to build the Iraqi state institutions from the scratch.

Post-Saddam state fragility was initially the outcome of immediate causes, particularly the American occupation and its consequences, however, historical factors such as a communal disputes, and ethnic and sectarian cleavages exacerbated the fragility. In other words, foreign occupation directly caused high state fragility in Iraq and activated the domestic grievances that further increased the degree of fragility. Therefore, a comprehensive understanding of state fragility in Iraq requires examining historical factors beside immediate external causes.

Iraq was built in an ethnically divided region. Social cleavages were exacerbated through the process of Iraqi state-building in which the privileged Sunni minority systematically alienated other ethnic and religious groups from power. From its creation in 1921 to its collapse in 2003, the Sunni-dominated state attempted to cover social cleavages and the exclusion of the other ethnic and religious groups under the surface of Iraqi nationalism and patriotism. When the Baathist regime was removed, the Iraqi society disintegrated. ${ }^{741}$ The historical cleavages and grievances appeared immediately after the collapse of the Baathist regime and were further exacerbated by the immediate causes of state fragility including the coalition's policies, the Shiite's ethnosectarian politics, and regional power politics.

In general, there are at least five elements in which one could trace the roots and trajectories of state fragility in Iraq: pathologies of communal tensions in modern Iraqi history, Sunni-led state building from 1921 to 2003, Saddam's downfall and the Sunnis' backlash, external occupation and US policies, and regional politics particularly Iran and Saudi Arabia's influence on post-Saddam

\footnotetext{
${ }^{740}$ Herring and Rangwala, Iraq in Fragments, 13-16; Dobbins et al., Occupying Iraq; Kathryn Westcott, "The Americans who Will Run Iraq," BBC, April 10, 2003 http://news.bbc.co.uk/2/hi/middle east/2932965.stm ${ }^{741}$ Stansfield, Iraq, 158.
} 
Iraqi affairs. A review of state formation in Iraq would help to examine these factors together in a historical context and search for trends and trajectories of fragility the country experienced over its lifetime.

\section{State Formation and State Fragility}

Since its creation in 1921, the sovereign state of Iraq has been an ethnic, sectarian and tribal competition arena on the one hand, and a ground for urban vs. rural, tradition vs. modernity, and nationalism vs. transnationalism struggles, on the other. ${ }^{742}$ Among others, the divide between Sunnis, Shiites, and Kurds has been the most defining element of Iraqi history.

The political development of Iraq can be categorized into three periods: the monarchical period (1921-1958), the Republican period (1958-1968), and the Baathist period (1968-2003). Although every project was based on a specific agenda they all followed a common goal, the maintenance of an Iraqi state and the creation of an Iraqi identity. ${ }^{743}$ The emergence of ethnosectarian violence and the rise of sectarian-based insurgent, separatist, and Islamist groups in the aftermath of the collapse of the Iraqi state in 2003, however, questions the success of this political agenda. The post-invasion development indicates that the Baathist regime, at its best, had covered the Iraqi social cleavages under the surface of a state-sponsored nationalism, patriotism, and elitism, rather than being able to integrate them into a unified national and political identity. Therefore, as soon as the surface was removed, social cleavages erupted and the Iraqi society "shattered into pieces." "744 However, despite this political shortage, the Baathist regime had developed a strong military and security apparatus, and a system of governance through which it

\footnotetext{
${ }^{742}$ Liam Anderson and Gareth Stansfield, The Future of Iraq: Dictatorship, Democracy, or Division? (New York: Palgrave, 2004), 5-7; Dawisha, Iraq, 5.

${ }^{743}$ Dawisha, Iraq, 7.

${ }^{744}$ Stansfield, Iraq, 158.
} 
could control its territory and suppress any internal disorder. Lacking in legitimacy, the Baathist government developed authoritarian institutions which could project coercive power throughout Iraq and developed an administration capable of managing Iraq's resources and providing basic services. ${ }^{745}$ Nevertheless, despite institutional development in security and economic sectors, the breakdown of an ethnic and sectarian based violence in the aftermath of the invasion shows that the Baathist regime was incapable of overcoming the historical roots of state weakness in Iraq. Thus, many causes of the post-invasion sectarian violence and political rivalries which sabotaged the reconstruction of the Iraqi state could be explored in the country's pre-invasion political development. Considering the significance of such a historical inquiry, I examine state formation and the roots of state fragility in Iraq in three state-building phases: the monarchical period (19211958), the Republican period (1958-1968), and the Baathist period (1968-2003).

\section{The Monarchical Period (1921-1958)}

Following the collapse of the Ottoman Empire at the end of the WWI, the creation of a state in the land of Mesopotamia, called Iraq, was originally determined by the British government. Iraq was created by the British on three disparate Ottoman provinces, Mosul in the north, Basra in the South, and Baghdad in the center. ${ }^{746}$ These provinces were dominated, respectively, by Kurds, Shiites, and Sunnis. Iraq's invention was the result of a political dealing between European powers on the partition of the Ottoman Empire at the end of the WWI, with Russia occupying Anatolia, France controlling Syria and Lebanon, and the UK taking Mesopotamia. ${ }^{747}$ Thus, the British invented Iraq

\footnotetext{
${ }^{745}$ Stansfield, Iraq, 96; Adeed Dawisha, Iraq: A Political History From Independence to Occupation (Princeton and Oxford: Princeton University Press, 2009), 220-21, 240.

${ }^{746}$ Dawisha, Iraq, 10.

${ }^{747}$ David Fromkin, A Peace to End All Peace: Creating the Modern Middle East, 1914-1922 (Harmondsworth: Penguin, 1991), 449-54; Andreas Wimmer, Nationalist Exclusion and Ethnic Conflict: Shadows of Modernity (Cambridge: Cambridge University Press, 2002), 172-73; Stansfield, Iraq, 35-36.
} 
on the Ottoman territories, demarcated its boundaries, and introduced to her the "accessories of a modern administration." ${ }^{748}$ Following the demarcation of the Iraqi borders, a constitutional monarchy was introduced to her as the form of governance at the Cairo conference in spring 1921, with King Faisal, a non-Iraqi Sunni, being crowned as the King. ${ }^{749}$ King Faisal was the third son of Sharif Husayn of Hijaz whose family traditionally fought for the independence of Arab lands from the Ottoman Turks. ${ }^{750}$ The King and the British administrators in Iraq designated Baghdad as the national capital which privileged the Sunni minority. Sunnis, compare to Shiites and Kurds, were historically a privileged sect in the region because of their sectarian ties to the Ottoman rulers and, therefore, their legitimacy to serve in the Ottoman army and administration. ${ }^{751}$

The newly established Iraq was diverse. There were Shiites, Sunnis, Kurds, and a number of smaller ethnic groups such as Turkmens, Assyrians, and Yazidis living in new Iraq. Shiites comprised 55 to 60 percent of the population, while Sunni Arabs formed a maximum of 20 percent, and the Kurds comprised some 20 percent of the population. ${ }^{752}$ The rest was composed of other ethnic groups, with Turkmens forming only less than 5 percent and Assyrians some 4-5 percent of the general population. ${ }^{753}$ Many Iraqis, especially, Shiites and Kurds were not happy with the idea of a non-Iraqi Sunni sovereign and Baghdad as the national capital. ${ }^{754}$ But despite their resistance, the decision was enforced by the British government and King Faisal. From the British perspective, the Sunni Arab elites were concentrated in Baghdad, as according to Winston Churchill, then

\footnotetext{
748 Stansfield, Iraq, 27.

${ }^{749}$ Dawisha, Iraq, 8.

${ }^{750}$ Dawisha, Iraq, 8-9, 80.

751 Anderson and Stansfield, The Future of Iraq, 139-53; Dawisha, Iraq, 31, 36, 69.

752 Anderson and Stansfield, The Future of Iraq, 20; Tony Koran, "Understanding Iraq's Ethnic and Religions Divide," Time Magazine, Feb. 24, 2006. (http://content.time.com/time/world/article/0,8599,1167476,00.html).

${ }^{753}$ Koran, "Understanding Iraq's Ethnic and Religions Divide," and Sargon George Donabed, Reforging a Forgotten: Iraq and the Assyrians in the Twentieth Century (Edinburg: Edinburg University Press, 2015 ), 1.

${ }^{754}$ Dawisha, Iraq, 14.
} 
Britain's Colonial Secretary, King Faisal offered hope for the "best and cheapest solution."755 Thus, in the earliest period of state formation in Iraq, the already marginalized Shiites and Kurds were further alienated from national politics. Over the entirety of monarchical rule, the five powerful ministries (premier, finance, interior, defense and foreign affairs) were controlled exclusively by Sunnis. ${ }^{756}$ According to one estimate, of the most important political leaders in Iraq over the same period close to 60 percent were Sunni Arab, 25 percent were Shiite, and 15 percent were Kurdish. ${ }^{757}$ A similar pattern prevailed within the armed forces. While Shiites were well represented in the lower ranks, the officer corps was exclusively a Sunni domain. ${ }^{758}$

Situating themselves in a reactionary and even adversary position against Sunnis, the Shiites and Kurds did not intend to be integrated into the Iraqi state in the monarchical period. Despite numerous measures, the monarchy was practically unable to integrate the Shiite south and the Kurdish north into the main body of politics. ${ }^{759}$

The period of monarchical rule in Iraq coincided also with the rise of Arab nationalism in the Middle East. Arab nationalism was a reaction to the post-WWI geopolitics of the Middle East and asserted that Arabs constitute a single nation and, thus, have to have a single state. King Faisal himself was in favor of Arab nationalism. However, while he never wanted to lose the sight of the broader Arab nationalist project, Faisal was devoted to build an Iraqi nation and state and then define it in a larger Arab identity. ${ }^{760}$ Therefore, the King was in the position to deal with both sectarianism and pan-Arab nationalism simultaneously. In general, in order to sustain Iraq's

\footnotetext{
${ }^{755}$ Janet Wallach, The Dessert Queen: The Extraordinary Life of Gertrude Bell (New York: Doubleday, 1995), 297.

${ }^{756}$ Geoff Simons, Iraq: From Sumer to Saddam (New York: St. Martins, 1994), 195.

${ }^{757}$ Phebe Marr, The Modern History of Iraq (Boulder: Westview Press, 1989), 144.

${ }^{758}$ Anderson an Gareth, The Future of Iraq, 20.

${ }^{759}$ Dawisha, Iraq, 9, 14.

${ }^{760}$ Ibid., 82 .
} 
stability, the King had to deal, at least, with three divides: Sunnis vs. Shiites and Kurds, Arabs vs. Kurds, pan-Arab nationalism vs. an Iraqi nationalism.

In the beginning, the very existence of the sovereign state of Iraq was challenged, particularly, by communal disputes among Sunnis, Shiites, and Kurds. To settle these disputes, Faisal and his successors, King Ghazi and King Faisal II, took democratic measures such as adhering to elections, and constitutional reforms. Their primary purpose was to integrate the 'other' political forces into the architected Iraqi state. But these measures did not work in practice and the state became increasingly fragile as a result of ethno sectarian disputes, on the one hand, and Arab vs. Iraqi nationalisms, on the other. The catalyst which changed power relations in favor of the Sunni-led Iraqi state permanently was the consolidation of a Sunni-led armed force in Iraq. The seeds of the Iraqi army was planted by King Faisal's lieutenants, a number of the Ottomantrained Iraqi officers who accompanied him during the WWI. ${ }^{761}$ Iraq's monarchical army, which was mainly formed of Sunnis from the middle-and lower-middle class families, quickly became a coercive guarantee against anti-state elements. ${ }^{762}$ Faisal's army emerged as the guardian of the state, initially, and developed into a force that challenged the state's autonomy subsequently. Soon after the Army's consolidation in Iraq, Army Generals engineered coups and toppled regimes one after another.

\section{The Republican Period (1958-1968)}

The Republic was the outcome of a military coup that ended the age of monarchy in July 1958. In the Republic of Iraq, the divide between pan-Arab nationalism and Iraqi nationalism occurred more intensive than ever before. The divide was more the result of the politics of the Middle East

\footnotetext{
${ }^{761}$ Ibid., 36.

762 Ibid., 36-37.
} 
than internal Iraqi politics. Following the July 1958 military coup, two officers, Brigadier Abd alKarim Qasim and Colonel Abd al-Salam Arif stood at the helm of Iraq's political office, respectively claiming the premiership and deputy-premiership. Additionally, the two officers assumed control of all military and security offices. However, the two had two different perspectives on the Iraqi state. Qasim advocated a localized Iraqi identity and independent Iraqi sovereign state centred on Iraqi nationalism, while Aref elevated pan-Arab nationalism above Qasim's Iraqi nationalism. ${ }^{763}$ The dispute between Qasim and Arif resulted in Aref's dispatching to Germany as the Ambassador in September 1959. Qasim remained as the 'sole leader' of Iraq.

Qasim's Iraqi nationalist regime was toppled in February 1963 in a military coup led by members of the Baath Party which initially advocated Arif's pan-Arab nationalism. ${ }^{764}$ Following the defeat of Qasim's regime, Aref (not a Baathist) was given the presidency. Qasim's power base centered on the army. Accordingly, the Republic of Iraq experienced a series of competitions between pan-Arab nationalism and an Iraqi identity, on the one hand, military efforts to move Iraq from the monarchy's pluralist aspirations toward authoritarianism and eventually personalization of power, on the other. ${ }^{765}$ Those competitions were, in fact, a reflection of the region's realities which were initially directed toward eroding sovereign states from the inside and outside. The Republican era ended with the July 1968 coup, led by Baathist Generals who were frustrated by the instability and successive political crises under the Republic.

\footnotetext{
${ }^{763}$ Ibid., 171-208.

764 Ibid., 174, 183, 197.

${ }^{765}$ Ibid., 207-208.
} 


\section{The Baathist Period (1968-2003)}

The Baathist regime, which was the outcome of the July 1968 military coup, opened a new chapter of authoritarianism and militarism in Iraq's history. Following the coup, Ahmad Hussein al-Bakr, the leader of the Baath Party, became the president and Saddam Hussein, then 31, became second to Bakr both in Party and the state hierarchy. Saddam's increasing power and influence in both the party and the state secured him Iraq's presidency in July 1979. Saddam's ascendency to the highest political position in Iraq was, in fact, the outcome of the gradual institutionalization and legitimation of his already established authority in the party and the army. ${ }^{766}$

By Saddam becoming the President of Iraq, the Iraqi government moved from being controlled by one party to being controlled by one man. ${ }^{767}$ In order to facilitate the President's absolute political control over the populations, the machinery of Saddam's government designed suppressive methods against the Kurds and Shiites in the 1980s and the 1990s. ${ }^{768}$ In addition to the anti-Shiite and anti-Kurd campaigns, the regime engineered a parallel policy of "winning the hearts and minds" of the poor and the educated Iraqis, in order to build its legitimacy basis on consent, not only coercion. ${ }^{769}$ But regardless of these efforts, Saddam's regime hardly extended its legitimacy basis beyond the Sunni Arab communities. ${ }^{770}$ Therefore, Saddam's regime suffered largely from very weak legitimacy.

\footnotetext{
${ }^{766}$ Ibid., 213

${ }^{767}$ Anderson and Stansfield, The Future of Iraq, 58-59. .

${ }^{768}$ For example, following the infamous anfal campaign against Kurds in 1988 which combined the systemic use of chemical weapons and resulted in destruction of 4,000 Kurdish villages and the forced relocation of up to 500,000 Kurds, Massoud Barzani, a Kurdish leader, publicly declared "Everything has ended; the rebellion is over. We cannot fight chemical weapons with bare hands." See Sandra Mackey, The Reckoning: Iraq and the Legacy of Saddam Hussein (New York: W.W. Norton \& Company, 2002), 263. See also Anderson and Stansfield, The Future of Iraq, 72.

${ }^{769}$ Anderson and Stansfield, The Future of Iraq, 62-64; Dawisha, Iraq: A Political History..., 220-21.

${ }^{770}$ Ibid; Ibid.
} 
Regardless of the obvious weakness in legitimacy, the regime enjoyed an effective authority. Saddam's state had a strong military and security apparatus which was capable of defending the state against external invasion and maintaining political order and social stability within the country. ${ }^{771}$ Saddam also tried to settle the historical dispute between pan-Arab and Iraqi nationalisms by signaling a new direction in promoting an Iraqi identity. In order to balance between the two nationalisms, the state designed two parallel policies. First, it instructed members of the Baath party to define themselves, simultaneously, as Arab nationalists (al-qawmiyya) and Iraqi patriots (al-wataniyya al-Iraqiyya) ${ }^{772}$ Second, the regime developed a political and cultural program which was designed to create a logical link between modern Iraq and ancient civilizations like the Sumerian, Akkadian, Babylonian, and Assyrian civilizations. ${ }^{773}$

Saddam's main purpose was to promote a unified Iraqi nation formed of Sunnis, Shiites, Kurds and other sects under a Sunni-dominated Baathist regime. ${ }^{774}$ The regime's concurrent inclusionist and exclusionist policies and programs were supported by the state's strongest pillar, the armed forces which ruthlessly suppressed any individual or group that resisted Saddam's “imagined community." Thus, the Baathist state covered all ethnic and sectarian cleavages under the surface of a pan-Arab slogan, a modern Iraqi nationalism, and a formal patriotism, all supported by the armed forces. Due to the state's strong monopoly over the use of physical violence in Iraq, there was no serious internal threat to the regime during Saddam's three-decade rule. However, a silent and invisible ethnic and sectarian dissatisfaction was constantly haunting under the surface

\footnotetext{
${ }^{771}$ Anderson and Stansfield, The Future of Iraq, 64.

${ }^{772}$ Amatzia Baram, Who Are the Insurgents? Sunni Arab Rebels in Iraq (Washington D.C.: United States Institute of Peace, Special Report No. 134, April 2005), 3; See also Amatzia Baram, Culture, History and Ideology in the Formation of Ba'thi Iraq (London: MacMillan, 1991).

${ }^{773}$ Dawisha, Iraq, 233

${ }^{774}$ Ibid., 235
} 
of the state's nationalism and coercion. ${ }^{775}$ Those dissatisfactions and cleavages erupted at all levels of the Iraqi society as soon as the Baathist regime was toppled in 2003.

\section{Causes of State Fragility}

As discussed earlier in this chapter, external invasion was the determinant cause of state collapse in Iraq. No empirical evidence supports that a localized political force could have removed Saddam from power in 2003. Although Saddam's regime was weakened due to multiple internal and external factors in the 1990s, it still remained the preeminent force in Iraq. ${ }^{776}$ State collapse in Iraq unleashed the communal forces that were controlled by the Baathist state for decades. The immediate outcome was an ethno sectarian violence which, in turn, furthered the level of state fragility and developed problems for the restoration of the state. ${ }^{777}$ Therefore, state collapse in Iraq was more externally driven than internally with sectarian mobilization and insurgency being the outcome of state collapse, not the other way around. ${ }^{778}$

On March 20, 2003, the United States and Britain crossed into Iraq from Kuwait defeating the Iraqi in less than three weeks and occupying Baghdad by April $9 .{ }^{.79}$ Baghdad's occupation formally marked the end of the Baathist era. The first and foremost consequence of the US invasion was the emergence of a violent insurgency and sectarian confrontation. The US Secretary of Defense under George W. Bush, Colin Powell, expressed the consequences of the invasion in an interview: "[an] unanticipated aspect of the post-war occupation was the extent to which the entire

\footnotetext{
${ }^{775}$ Stephan Rosiny, "The Rise and Demise of the IS Caliphate," Middle East Policy 22(2), summer 2015: 95.

${ }^{776}$ Main factors that weakened the Iraqi state in the 1990s were both inernal and external. Internally, the gradual erosion of state-society relations with the Sunni-led state increasingly exercising authority by coercion, fatally decreased the state's already poor legitimacy. Externally, the Iran-Iraq war (1980-1988), the Gulf War (1990-1991) and the U.N. sanctions (1990s) dramatically reduced the Iraqi state's capacity.

${ }^{777}$ Stansfield, Iraq, 198.

${ }^{778}$ For internal and external causes of state failure see Andrew Flibbert, "The Consequences of Forced State Failure in Iraq," Political Science Quarterly 128(1), 2013: 68.

${ }^{779}$ Dawisha, Iraq, 242.
} 
structure of military and civil society collapsed so completely as the war ended, leaving a vast problem for the American troops to handle." 780

Much of the trouble came from the Sunni areas that basically seemed unable to accept the loss of their status as the default rulers of the country. ${ }^{781}$ Following the collapse of the Baathist regime, three prevailing political forces with different, and to some extent contradictory, political agendas emerged: A Shiite religious trend which sought to dominate the national government, a Kurdish nationalist agenda in which Kurdistan's autonomy from Baghdad was a priority, and a Sunni Arab position that was formed in reaction to both the post-Saddam domestic politics and the US invasion. The Shiite political force was divided mainly between different poles of authority, the Kurds were divided between two major Kurdish political parties, and the Sunni Arabs split between ex-Baathists, neo-Baathists and an array of insurgent and Islamist groups. ${ }^{782}$ The Shiite rebellion and the Kurdish resistance were not against the post-Saddam political process as a whole but wanted to maximize power under the status quo, whereas, the Sunni insurgency was against the status quo, the Shiite-led government in Baghdad, and Kurdish separatism. The Shiite rebellion, which emerged primarily as anti-occupation militant groups and was massively financed and backed by Iran, in principle, did not aim to overthrow the Shiite-led government in Baghdad. Rather, its objectives were more to maximize influence in Baghdad. ${ }^{783}$ The two main Shiite militia groups, the Sadr Movement and Hawza al-Marjaiyya led respectively by Muqtada al-Sadr and Ayatollah Ali Sistani, sought a political role in the government rather than entirely removing it. ${ }^{784}$ The post-Saddam government was formed of mainly two Shiite parties, the Supreme Council for

\footnotetext{
${ }^{780}$ Steven R. Weisman, "The Struggle for Iraq: Diplomacy; Powell Gave Iraq 6 Months to Write New Constitution," New York Times, Sept. 26, 2003. (http://www.nytimes.com/2003/09/26/world/struggle-for-iraq-diplomacy-powellgives-iraq-6-months-write-new-constitution.html).

${ }^{781}$ Dawisha, Iraq, 244.

${ }^{782}$ Stansfield, Iraq, 4-5.

${ }^{783}$ Ibid., 176.

${ }^{784}$ Ibid., 176-178.
} 
Islamic Revolution in Iraq (renamed Islamic Supreme Council of Iraq (ISCI) in 2007) and the Islamic Dawa Party. The alliance of the two parties, called the United Iraqi Alliance, won the December 2005 general elections and formed the first Iraqi government following the demise of the Baathist regime. Following the formation of the government, the military branches of the twoparties, including the Badr Brigade and the ISCI army, were absorbed into the government. ${ }^{785}$

Likewise, the Kurdish main parties, the Patriotic Union of Kurdistan (PUK) led by Jalal Talabani and the Kurdistan Democratic Party (KDP) led by Masoud Barzani which jointly controlled Iraq's Kurdistan region since the 1992 regional election, did not seek to remove the Shiite-led government in Baghdad. ${ }^{786}$ Rather, they mainly struggled for more influence in Baghdad and maintaining the autonomy of the Kurdistan region. The Kurdish parties were successful in achieving their purposes concerning both Iraqi and Kurdistan politics - Talabani become Iraq's President (2005-2014) and Barzani was appointed the President of the Kurdistan region in 2005. ${ }^{787}$ Therefore, the two parties' militia wings, composed of some 80,000 Kurdish combatants and mostly organized in Peshmerga units, were not considered a serious threat to the Iraqi government and the Coalition. ${ }^{788}$ Therefore, the Shiite and the Kurdish militias were largely used to fight the Sunni insurgent and Islamist groups. In contrast, the Sunni insurgency basically emerged against the Shiite-led government and the Coalition forces. Its initial objective was to defeat the Coalition, remove the Shiite-led government and replace it with a Sunni Arab dominated regime. ${ }^{789}$ IS was the outcome of the development of this insurgency into a more uniform organization. The origins

\footnotetext{
${ }^{785}$ Susanah George, “Breaking Badr,” Foreign Policy, November 6, 2014 (http://foreignpolicy.com/2014/11/06/breaking-badr/).

786 See Anderson and Stansfield, The Future of Iraq, 172-179.

${ }^{787}$ See "Talabani Elected as Iraqi President," the Guardian, April 6, 2005 (https://www.theguardian.com/world/2005/apr/06/iraq); see also "President Masoud Barzani," Kurdistan Region Government (http://cabinet.gov.krd/p/p.aspx?1=12\&p=232).

${ }^{788}$ For the number of Kurdish militiamen see Anderson and Stansfield, The Future of Iraq, 179.

${ }^{789}$ Stansfield, Iraq, 178-182.
} 
of IS can be traced mainly in the process of the development of those Sunni insurgent groups into a jihadi organization that functions globally.

\section{Aspects of State Fragility}

In order to prevent the expansion of the insurgency and facilitate the transition of power to a democratically elected Iraqi government, the Coalition set a step by step political process which included a direct rule period in which the Coalition would rule Iraq through the American-led administration, the CPA. CPA was assigned to form an interim Iraqi administration. The interim government would facilitate the establishment of a transitional government. A new constitution would be approved by the transitional government which would pave the way for general elections and an elected Iraqi government. ${ }^{790}$

According to this plan, from May 2003 until June 28, 2004, when sovereignty was transferred to the Iraqis, the CPA ruled Iraq directly. Immediately after coming to existence, the CPA planned a policy that included disbanding the Iraqi military, de-Baathifying the Iraqi state, and giving power to the Shiites with the cost of alienating the well-trained Sunni state administrators. In the meantime, an Iraqi Governing Council (IGC) was appointed in mid-July 2003 to provide an Iraqi face to decision-making. IGS created Iraq's Transitional Administrative Law (TAL) which dissolved the IGS into an interim government under the premiership of Ayad Allawi, an ex-Baathist Shiite who went abroad in 1971 and in the early 1990s created an antiSaddam organization based in London. ${ }^{791}$ With the formation of Alawi's interim government, the CPA and the 'direct rule' era came to an end formally on June 28, 2004. The TAL had set a strict

\footnotetext{
790 Dawisha, Iraq, 246.

791 Anthony Shadid, "Iraq's Last Patriot," The New York Times Magazine, February 4, 2011 (http://www.nytimes.com/2011/02/06/magazine/06ALLAWI-t.html).
} 
timeline for the country's transition to democracy (i.e. elections to be held by the end of January 2005 which would produce a transitional parliament and government that would draft a permanent constitution, followed by general elections). ${ }^{792}$

The first Iraqi elections to form a transitional government took place on January 30, 2005, in which the Shiites' United Iraqi Alliance (UIA) received over 51 percent seats of the transitional parliament, and the Kurdish Alliance took some 27 percent. While, Ayad Allawi's Sunni campaign received only 14 percent of the seats. ${ }^{793}$ The transitional parliament marked the ethnic and sectarian basis of the post-Saddam Iraqi politics, however, Iraq's societal divide became clearer in the general elections which finally took place on December 15, 2005. During the December 2005 election campaigns, for example, the Shiite UIA hardly bothered to electioneer in the Kurdish areas, and Kurd candidates avoided to campaign in the southern Shiite or in the central Arab Sunni provinces. ${ }^{794}$ The election results show that Kurdish parties received 100 percent of the vote in Kurdish areas, Sunni parties received 88 percent of the vote in Sunni areas, and Shiite parties received 86 percent of the vote in Shiite areas. ${ }^{795}$ As a result, the Shiite UIA formed the government by winning 46.5 percent of seats in the parliament, the Kurdish Alliance received more than 19 percent, and the Concord Front (Sunnis) received only 16 percent of the seats. ${ }^{796}$

Nouri al-Maliki was elected as the Prime Minister who intensified Iraq's already emerging ethno sectarian divide by discriminating against Sunni Arabs in Iraq's political and security arenas. ${ }^{797}$ He filled the key cabinet positions with Shiite figures and fired Sunni commanders from

\footnotetext{
792 Dawisha, Iraq, 246

793 Ibid., 248-49.

${ }^{794}$ Ibid., 252-53.

795 Adeed Dawisha and Larry Diamond, “Iraq's Year of Voting Dangerously,” Journal of Democracy 17(2), 2006: 100.

796 Dawisha and Diamond, "Iraq's Year of Voting Dangerously." 99.

${ }^{797}$ Priyanka Boghani, "In Their Own Words: Sunnis on Their Treatments In Maliki’s Iraq," PBS, October 28, 2014 (http://www.pbs.org/wgbh/frontline/article/in-their-own-words-sunnis-on-their-treatment-in-malikis-iraq/).
} 
the newly established Iraqi army in favor of Shiites during his 2006-2014 tenure. This policy turned what was supposed to be a national army into "a little more than a sectarian militia" that took orders from the Prime Minister and his inner circle. ${ }^{798}$ Many American officials in Iraq at that time described Maliki's nepotism in the army not only as intensifying the sectarian divisions in Iraqi society but also as enhancing the level of corruption within the security forces. According to Jack Keane, a retired American Army vice chief of staff and architect of the surge of 30,000 additional US troops into Iraq in 2007, "Malaki went into that army and pulled out all of its distinguished leaders, whose guys were devoted to them, and put in these cronies and hacks. And those guys pocketed the money that was supposed to be used for training."799

Overall, from the creation of the CPA to the 2005 elections, Iraq lacked a regular state system and a functioning government. The 2005 general elections formed a government which indicated severe weakness in governance. By the time CPA handed authority over to the Iraqi Interim Government on June 28, 2004, the Coalition forces had made little progress in creating an effective Iraqi armed force (IAF) that could control the situation. Without Iraqi forces being able to take on security tasks, coalition forces felt compelled to police Iraq in ways that were unpalatable to large elements of the Iraqi public. ${ }^{800}$ Therefore both the weak IAF and the Coalition's extension of operations in order to fill the security gap in Iraq caused the extension of sectarian, anti-Occupation and criminal activities. ${ }^{801}$ By fall 2006, violence between Sunnis and Shiites increased with 100 to 130 people being killed every day, the vast majority dying because

\footnotetext{
${ }^{798}$ Mark Thompson, "How Disbanding the Iraqi Army Fueled ISIS," Time Magazine, May 28, 2015 (http://time.com/3900753/isis-iraq-syria-army-united-states-military/).

${ }^{799}$ Thompson, "How Disbanding the Iraqi Army Fueled ISIS."

${ }^{800}$ Andrew Rathmell, Olga Oliker, Terrence K. Kelly, David Brannan, Keith Crane, Developing Iraq's Security Sector: The Coalition Provisional Authority's Experience (Santa Monica, Arlington, Pittsburgh: RAND, 2005), 3.

${ }^{801}$ Rathmell, et al., "Developing Iraq's Security Sector," 1; Rick Barton and Bathsheba Croker, Progress or Peril? Measuring Iraq's Reconstruction (Washington D.C.: Center for Strategic and International Studies, September 2004), 5-14.
} 
of targeted sectarian attacks. ${ }^{802}$ Therefore, the most defining characteristic of the first decade of the post-Saddam Iraq was an increasing fragility at all levels of the Iraqi state and society. The newly engineered state institutions, in this period, endorsed identity-based loyalties through purposeful policies and decisions which exacerbated the already expanding ethno sectarian divide in society. Plagued by a political and security vacuum, post-Saddam Iraq became the arena of a power struggle between Sunnis and Shiites on the one hand, and the scene of a regional power struggle, on the other. ${ }^{803}$ As a result, the level of Iraq's state fragility increased so significantly that it created the political space afforded to Iraq's violent insurgency which developed into IS.

All in all, lack of legitimacy and authority were the most effective aspects of state fragility in post-Saddam Iraq which developed the conditions favorable to the emergence of IS. Empirical findings show that the post-Saddam Iraqi government lacked in legitimacy in terms of lacking a broad-based political regime. State legitimacy was mostly affected by three factors: lack of political participation, sectarian politics, and external intervention. Moreover, the state indicated a severe weakness in authority in terms of lacking a legitimate and effective security and military apparatus. And finally, economic decline, poverty, and poor administrative capacity were the main aspects of poor capacity in the post-Saddam Iraq. However, evidence and findings do not confirm a strong relationship between lack of capacity and the establishment of IS. The remainder of this chapter investigates the relationship between lack of legitimacy and authority and the rise of IS. Although lack of capacity did not play a determinant role in the emergence of IS, for the sake of further clarity, I also briefly examine the relationship between poor capacity and the rise of IS.

\footnotetext{
${ }^{802}$ Dawisha, Iraq, 262.

${ }^{803}$ Geneive Abdo, The New Sectarianism: The Arab Uprising and the Rebirth of the Shia-Sunni Divide (Washington D.C.: The Brookings Institute, April 10, 2013).
} 


\section{Lack of Legitimacy}

\subsection{Lack of Political Participation}

According to the three basic sources of legitimacy, i.e., traditional, charismatic and rationallegal, ${ }^{804}$ post-Saddam Iraqi state lacked entirely the traditional and charismatic sources of legitimacy and simultaneously failed to develop a rational-legal source of legitimation. The Coalition force's state-building strategy was not to create a regime in which the obedience of people is based on the capacity of a leader or an established tradition. ${ }^{805}$ Rather, the plan was to build a rational-legal state grounded in modern laws and procedures ${ }^{806}$ Accordingly, the Coalition's purpose was to legitimize the state by enhancing the rule of law, re-establishing key state institutions and strengthening the economy, rather than considering the broader social, cultural and political cleavages of the country in the state-building process. ${ }^{807}$ The Coalition's attempt to rationalize/legalize the legitimate sources of the Iraqi state, however, met with very little success in the early post-invasion years.

The Coalition's primary emphasis on fostering a legal/rational legitimacy in post-Saddam Iraq along democratic governance principles required considerable investment and time. ${ }^{808}$ The Coalition's policy was to enhance state legitimacy by improving political participation and government performance. ${ }^{809}$ Political participation refers to majority-minority relations, regular

\footnotetext{
${ }^{804}$ Max Weber, "The Three Types of Legitimate Rule," trans. Hans Gerth, Berkeley Publications in Society and Institutions, 4(1), 1958: 1-11.

${ }^{805}$ Azeez, "Reconstructing Iraq," 77-87.

${ }^{806}$ For the rational-legal sources of authority see Webber "The Three Types of Legitimate Rule;" for the postSaddam statebuilding in Iraq see Azeez, "Reconstructing Iraq," 77-87.

${ }^{807}$ Ahmad Hassin, "The Failure of Neo-Liberal State-Building in Iraq: Assessing Australia's Post-Conflict Reconstruction and Development Initiatives," Australian Journal of Politics and History 62(1), 2016: 87-99.

${ }^{808}$ Brinkerhoff et al., "Service Delivery and Legitimacy in Fragile and Conflict-Affected States," 280.

${ }^{809}$ Political participation includes system-level aspects of legitimacy. See M. Stephen Weatherford, "Measuring Political Legitimacy," American Political Science Review 86(1), 1992: 150; Bo Rothstein, "Creating Political Legitimacy: Electoral Democracy Versus Quality of Government," American Behavioral Scientist 53(3), 2009: 311330 .
} 
and frequent elections and accountability, and government performance in terms of how well institutions and officials discern and act on the polity's best interest. ${ }^{810}$ Political participation therefore relates to the power-sharing mechanisms, and government performance refers to the institutional effectiveness of the state. Improvement in participation and governance reinforces the legitimacy of the state as a recognized entity responsible for effective state-society relations and political order. ${ }^{811}$ Political participation and government performance, in this sense, provide a condition under which the citizens voluntarily accept state authority and obey laws which, in turn, enables the exercise of state power through consent rather than coercion. ${ }^{812}$ Lack of, or poor, political participation and government performance disrupts state-society relations making the exercise of state power difficult. When state-society relations are disconnected, dissatisfied communities stop obeying the law and rise as insurgent or opposition groups. ${ }^{813}$

The belief in post-Saddam Iraq was that inclusive political participation and good government performance would increase legitimacy in Baghdad. But despite the effort, political participation and government performance in Iraq remained poor for at least one decade following the invasion. The electoral democracy and free voting which was presumed by the Coalition as the tool of political participation resulted in the polarization of politics and sectarian-based voting. ${ }^{814}$ Moreover, government performance in this period remained severely weak with Iraq's security and services provision sectors being ineffective. The contribution of Iraq's weak security apparatus

\footnotetext{
${ }^{810}$ Weatherford, "Measuring Political Legitimacy," 150; Rothstein, "Creating Political Legitimacy."

${ }^{811}$ Brinkerhoff et al., "Service Delivery and Legitimacy in Fragile and Conflict-Affected States," 274.

812 OECD, The State's Legitimacy in Fragile Situations: Unpacking Complexity, Conflict and Fragility (Paris: Organization for Economic Co-operation and Development, 2010), 7; Brinkerhoff et al., "Service Delivery and Legitimacy in Fragile and Conflict-Affected States," 274.

${ }^{813}$ Brinkerhoff et al., "Service Delivery and Legitimacy in Fragile and Conflict-Affected States," 275-276; Rothstein, "Creating Political Legitimacy," 319-323.

${ }^{814}$ Raad Sami al-Tamimi, and Kevin E. Grisham, 'Elections as a Tool for Political Participation in Iraq,' International Journal of Contemporary Iraqi Studies 7(3), 2013: 233-249; Stanfield, Iraq, 182-191; Kristina Arvanitis, "Lessons from Iraq: Electoral Legitimacy in the Shadow of Ethnoreligious Conflict," Templet Int' and Comp. L. J. 20(2), 2006: 532-535.
} 
to the rise of IS is broadly discussed in next section, and empirical data does not prove the determinant contribution of the weak services delivery sector in Iraq to the emergence of this organization. Therefore, the relationship between lack of legitimacy and the rise of IS, in this chapter, is mainly examined through aspects of political participation in post-Saddam Iraq. In order to provide a clear account of political participation in Iraq and its contribution to the rise of IS, political participation in post-Saddam Iraq is examined in three phases: the pre-2005 elections, the 2005 elections, and the post-election phases. The pre-election phase consists of a time period from the US invasion in April 2003 until the Iraqi general elections in December 2005. The elections phase includes a time from the transitional election in January 2005 to the first general elections in December 2005. The post-election phase encompasses a time frame from 2006 to the end of Noori al-Maliki's second government in 2014.

In the pre-election period, the CPA removed Sunni Arabs from Iraq's government through the de-Baathification project and marginalized them in the new political process. Following the de-Baathification of Iraq's military and civil services the CPA designed the establishment of a new political regime by forming an Iraqi provisional government called the Iraqi Governing Council (IGC) in July 2003. In order to provide the IGC with an inclusive feature, the CPA included five Sunni Arabs in the IGC, however Sunnis were largely marginalized in this organization both in terms underrepresentation and their role in decision-making. The IGC was composed of 25 members including sixteen Shiites, five Kurds, five Sunnis, one Assyrian and one Turkmen. ${ }^{815}$ Thus, the first domestic governing body in the post-Invasion Iraq was dominated by Shiite and

\footnotetext{
${ }^{815}$ IGC was a coalition of six parties, including two Shiite (Abd al-Aziz al-Hakim's SCIRI and Ibrahim al-Jafari's Dawa), two Kurdish (Massoud Barani’s KDP and Jalal Talabani's PUK), and two pro-American "centrist" (Ayad Alawi's INA, and Ahmed Chalabi's INC) parties. See Stansfield, Iraq, 169.
} 
Kurds, both suppressed by Saddam and unified in the post-Saddam political process. ${ }^{816}$ The Sunni members of the IGC included individuals who were disconnected from the society and were considered by Sunnis as parts of a process of "disempowering Sunni Arabs for the benefit of Shiites and Kurds." ${ }^{\prime 817}$ The presence of Sunni Arab figures such as Naseer Chderchi and Adnan Pachachi in the IGC was more celebratory. Marginalization of Sunni Arabs continued with the formation the Iraqi Interim Government (IIG) in June 2004. The IIG, which replaced both the CPA and IGC, was filled from top to bottom with politicians from IGC. ${ }^{818}$ Shiites and Kurds were placed in leading positions, with only "the celebratory position of the President given to a Sunni Arab returnee from London, Ghazi al-Yawer." ${ }^{\prime 19}$ This process led to the further polarization of Iraq's politics and society, reducing the state's legitimacy in the eyes of Sunni Arabs who were experiencing exclusion and marginalization at all levels of Iraqi politics. Accordingly, the CPA's legacy to Iraq was to move the country's political life from being ideological under Saddam to becoming severely divided after his removal. ${ }^{820}$

The post-Saddam polarization of political life became more evident in the second phase, during the two general elections. All electoral camps were formed mainly along sectarian lines, the people invariably voted based on their sectarian ties, and most significantly the electoral system was designed with the presumption of a sectarian voting. ${ }^{821}$ The January 2005 elections to form a transitional parliament and government was boycotted by the Sunni Arab parties because they claimed that they were "disfranchised in the pre-election political process, therefore, they do not

\footnotetext{
${ }^{816}$ See Sharon Otterman, "Iraq: Iraq's Governing Council," Council on Foreign Relations May 17, 2004 (http://www.cfr.org/iraq/iraq-iraqs-governing-council/p7665),

${ }^{817}$ Stansfield, Iraq, 170.

${ }^{818}$ Ibid., 175.

${ }^{819}$ Ibid., 175.

${ }^{820}$ Ibid., 169 .

${ }^{821}$ Ibid., 182-191; Dawisha, Iraq, 252-253.
} 
have equal access to resources to compete with other opposition groups." ${ }^{\prime 222}$ The result of the boycott was a very low turnout in Sunni areas. For example turnout in Mosul was as low as 10 percent, and most of those were Kurds. ${ }^{823}$ The pattern was repeated in Tikrit, Baquba and Ramadi, Fallujah and parts of Baghdad. Whereas, the turnout in Kurdish areas were as high as 90 percent and in Shiite areas some 80 percent. ${ }^{824}$ The results were far from satisfying the Sunni Arab communities that used to rule Iraq since its creation as a sovereign state in the $1920 \mathrm{~s} .{ }^{825}$ The Shiites and Kurds winning respectively 48 and 25 percent of the votes dominated both the transitional parliament which was assigned to draft a permanent constitution and the transitional government which had to prepare for the general elections. ${ }^{826}$ By contrast, the Iraqi List, the major Sunni Arab party that participated in the elections, won only 13 percent of the vote. ${ }^{827}$ The outcome was a polarized parliament and government in which Sunni Arabs were largely isolated. Therefore, other methods of including Sunnis in the government were demanded. ${ }^{828}$ Likewise, social and political divides were reflective in the December 2005 general elections with electoral campaigns and voting being deeply sectarian. During the electoral campaigns the Shiite UIA hardly bothered to electioneer in the Kurdish areas, and Kurd candidates avoided to campaign in the Shiite and Sunni Arab provinces. ${ }^{829}$ The result was as follows: Kurdish parties received 100 percent of the vote in Kurdish areas, Sunni parties received 88 percent of the vote in Sunni areas, and Shiite parties received 86 percent of the vote in Shiite areas. ${ }^{830}$ As a result, the UIA dominated the assembly

\footnotetext{
${ }^{822}$ Arvanitis, "Lessons from Iraq: Electoral Legitimacy in the Shadow of Ethnoreligious Conflict," 531.

${ }^{823}$ Stanfield, Iraq, 182-191.

${ }^{824}$ Ibid., 182-191.

${ }^{825}$ Ibid., 182-191.

${ }^{826}$ Ibid., 182-183.

${ }^{827}$ Ibid., 182-191.

${ }^{828}$ Arvanitis, "Lessons from Iraq: Electoral Legitimacy in the Shadow of Ethnoreligious Conflict," 549-550.

${ }^{829}$ Dawisha, Iraq, 252-53.

${ }^{830}$ Adeed Dawisha and Larry Diamond, "Iraq's Year of Voting Dangerously," Journal of Democracy 17(2), 2006: 100 .
} 
with receiving 41.2 percent of the vote followed by the Kurdish Alliance which received 21.7 percent. The Iraqi Accord Front, a union of various Sunni Arabs received 15.1 percent of the votes securing 44 seats in the parliament. ${ }^{831}$ Regardless of violent threats by AQI which denounced the Iraqi elections as a "satanic project that violates God's law," 832 Sunnis' participation in the general election of January 2005, with a turnout of 70 percent of registered voters, showed a remarkable increase. ${ }^{833}$ The Sunnis cooperation and high turnout raised hopes that they would join the political process to build a new political system and diminish the insurgency. ${ }^{834}$ Nevertheless, the Sunnis' minimal role and the growth of sectarianism in post-election political process challenged the possibility of forming an inclusive legitimate government in Baghdad.

In phase three, the post-election political process, state legitimacy dropped in Sunni areas more than before. The Shiite-led government, in this period, exacerbated the sectarian politics and the further isolation of Sunnis Arabs, and even tried to limit the power of Kurd parties. ${ }^{835}$ Following the general elections, a new government was formed on May 20, 2006, under Nouri alMaliki, the leader of the Shiite Dawa Party. ${ }^{836}$ In the general elections, the Accordance Front of Sunni Arabs won 44 of the Iraqi parliament's 275 seats and secured the position of deputy prime minister and six cabinet ministries. ${ }^{837}$ But following the formation of the new government, the

\footnotetext{
${ }^{831}$ Stanfield, Iraq, 182-191.

832 Jeffrey White and Brooks Neuman, "The Sunnis, the Insurgents, and the Elections," The Washington Institute, December 20, 2005 (http://www.washingtoninstitute.org/policy-analysis/view/the-sunnis-the-insurgents-and-theelections).

${ }^{833}$ Esther Pan, "Q\&A: Iraq: Sunnis, the Elections, and the Insurgency," The New York Times, December 23, 2005 (http://www.nytimes.com/cfr/international/slot3_122305.html?pagewanted=all).

${ }^{834}$ Pan, "Q\&A: Iraq."

${ }^{835}$ Dylan O’Driscoll, “Autonomy Impaired: Centralisation, Authoritarianism, and the Failing Iraqi State," Ethnopolitics, Sept., 2015, (1-18)

${ }^{836}$ U.N. Security Council, "With the New Government, Iraq's Three-Year Political Transition Complete, Although Accompanied by Instability, Violence, Security Council Told," United Nations SC/8751, June 15, 2006 (https://www.un.org/press/en/2006/sc8751.doc.htm).

${ }^{837}$ Mark Tran, "Iraq's Biggest Sunni Block Quit Government," The Guardian, August 1, 2007 (https://www.theguardian.com/world/2007/aug/01/iraq.marktran); "Full List of Iraqi Cabinet Ministers," The New York Times, May 20, 2006 (http://www.nytimes.com/2006/05/20/world/middleeast/20cnd-cabinet.html).
} 
Accord leadership consistently claimed that they did not have "practical influence" in the government. As a result, the accord withdrew its ministers from the government in August 2007, accusing Maliki's Shiite-led coalition of failing to consult it on key issues ${ }^{838}$ The main reason for the Sunnis' withdrawal from the government, according to Adnan al-Dulaimi, the head of the Accordance Front, was the government's sectarian behavior: "we don't want to take part in a government which claims it is a national unity one, but instead is sectarian rather than Iraqi." ${ }^{839}$ Although the Accord rejoined the government a year later, sectarianism and sectarian-based decision-making in the government remained an intact issue, and continued growing in Maliki's first (2006-2010) and second (2010-2014) periods in office. In the first period of his government, Maliki tried to limit the power of Kurds and Sunnis by forming a centralized Shiite-led government in Baghdad. In the second period of his rule, Maliki intensified the centralization of power with himself becoming minister of defense, minister of interior, minister of state for national security and commander-in-chief of the armed forces, all alongside his role as Prime Minister ${ }^{840}$ In this period, Maliki heavily relied on non-political means such as accusations of terrorism and treason to eliminate his opponents, mainly the Sunni politicians. The elimination process began with the trial of Sunni Vice President of Iraq, Tariq al-Hashimi. Hashimi, who was charged with "running death squads" and sentenced to death in absence after fleeing to Turkey ${ }^{841}$ Similar accusations and arrests were followed by the arrest, on terrorism charges, of many staff and bodyguards of Sunni Finance Minister, Rafie al-Issawi, and the arrest of al-Iraqiya MP Ahmed al-Alwani, also under terrorism charges. ${ }^{842}$ Maliki's sectarian campaign and amalgamation of power under his

\footnotetext{
${ }^{838}$ Tran, "Iraq's Biggest Sunni Block Quit Government."

${ }^{839}$ Ibid.

${ }^{840}$ O’Driscoll, “Autonomy Impaired,” 7.

${ }^{841}$ Ibid.

${ }^{842}$ Ibid.
} 
command led to an exacerbation of Kurdish separatism, Sunni extremism, and the shrinking of his government's legitimacy beyond Shiite communities. ${ }^{843}$

Overall, due to the lack of broad-based political participation, state legitimacy in the three phases of the post-Saddam political process could not sink its roots in all corners of Iraq's society. State-society relations, particularly the relationship between the Sunni society and the Shiite-led government remained highly fragile. This process created a political atmosphere making Sunnis receptive to a Sunni-led insurgency, allowing the insurgency to expand in Sunni areas and unify under the banner of a Sunni-led extremist group against a state they considered illegitimate. ${ }^{844}$ While Sunnis viewed the regime as sectarian and illegitimate, the Sunni-led insurgency played a far more prominent, and legitimate, role than any of the Iraqi governmental or military organizations in the Sunni Triangle. ${ }^{845}$ Under this condition, the Sunni jihadis which were primarily organized into AQI and other anti-Shiite and anti-Coalition SJGs increased the recruitment of dissatisfied Sunnis and the de-Baathified Iraqi soldiers and officers. ${ }^{846}$ As a result, according to an International Crisis Group report, the evolution of the Sunni insurgency toward the formation of a uniform Sunni-led extremist organization became inevitable: "Sunnis saw their only chance of surviving in Iraq was to fight as Sunnis against a US-sponsored Shiite-led government." ${ }^{847}$ Thus, the emergence of the Iraq-based insurgency and its development into a Salafi-Jihadi organization significantly benefited from conditions provided by a lack of state legitimacy in all three phases of political development in the post-Saddam Iraq. The pre-election phase, in which Sunnis were disenfranchised in Iraqi politics and marginalized from the IGC and

\footnotetext{
${ }^{843}$ Ibid., 1-18.

${ }^{844}$ Max Boot, "We Can’t Afford to Let ISIS Run Wild in Iraq," The Spectator August 16, 2014 (https://www.spectator.co.uk/2014/08/defeat-isis-yes-we-can/).

${ }^{845}$ O'Driscoll, “Autonomy Impaired,” 1.

${ }^{846}$ Rosiny, "The Rise and Demise of the IS Caliphate," 95.

${ }^{847}$ Patrick Cockburn, The Rise of Islamic State: ISIS and the New Sunni Revolution, (London and New York: Verso, 2014), 69.
} 
IIG, contributed to the rise and expansion of an anti-Shiite and anti-Coalition insurgency. Young Sunni Arabs and the de-Baathified soldiers, who considered the IGC and IIG illegitimate, created a number of domestic insurgent groups or joined Zarqawi's global jihadi organization. Zarqawi's 'anti-Crusader-Safavid' campaign in this period was reinforced by the Sunnis' dissatisfaction with the post-invasion political process. This, in turn, contributed to Zarqawi's "Iraqification" of JTJ or the recruiting of Iraqis from the Sunni Triangle and attempting to sink roots into Sunni society. ${ }^{848}$ The second phase, the 2005 elections, was another effort to increase the state legitimacy through elections. But despite the hopes for establishing a unified Iraqi government, the sectarian-based voting and outcome in which Sunnis were the main losers meant the state remained illegitimate in Sunni society. This phase motivated Sunni individuals, who felt denied of being a part of the political process or coming to power through a democratic political participation process, to begin supporting the insurgency. And finally, the Iraqi state's legitimacy was gravely affected by the third phase of Iraq's political process due to further marginalization of the Sunnis, Maliki's centralization of power, and his the usage of military force against the Sunnis who protested his policies. This phase led the insurgency toward the establishment of a unified Sunni front against the Shiite-led government and its international sponsor, the United States. The merging of AQI with five other Iraq-based insurgent groups under an umbrella organization called Majlis Shura al-Mujahedeen (MSM) in January 2006 which rebranded itself in October of the same year as the

\footnotetext{
${ }^{848}$ Safavid or Safawi, refers to the Iranian Safawi dynasty (1501-1722). It is used by many Sunni Arab Iraqis today to describe the alleged Iranian influence and to discredit their Shiite fellow citizens as "aliens." The "CrusaderSafavid" alliance referred to the alliance between the "allied forces" and the post-Saddam Shiite-led Iraqi government. The Sunni insurgency primarily termed the Shiite-dominated Iraqi government, the Safawi rule. See also Bradley Graham, "Zarqawi 'Hijacked' Insurgency: U.S. General Says Foreign Fighters Now Seen as Main Threat," Washington Post, September 28, 2005 (http://www.washingtonpost.com/wpdyn/content/article/2005/09/27/AR2005092701601.html); Eisenstadt and White, "Assessing Iraq's Sunni Arab Insurgency," 15-16; Eisenstadt and White, "Assessing Iraq's Sunni Arab Insurgency," 15; Greg Miller and Tyler Marshall, "More Iraqis Joining Zarqawi's Cause," Los Angeles Times, September 15, 2005, p1.
} 
Islamic State of Iraq (ISI) took place under this condition. ${ }^{849}$ Prime Minister Maliki's second period in office, which led to severe state failure, sectarian division and a vanishing of state legitimacy, twinned with the Syrian civil war, developed the condition under which ISI developed from an Iraq-based extremist group to an organization that acquired a transnational identity and operated beyond sovereign borders. By capturing territory and being capable of moving beyond sovereign borders, the ISI announced the formation of a pan-Islamic State in Iraq and Syria. Thus, when the Coalition-sponsored Iraqi state could not extend its Weberian 'legal-rational' basis of legitimacy into Sunni areas, the Sunni-led insurgency announced the formation of an Islamic State as an alternative political organization for Sunnis and based it on a specific form of traditional legitimation, religious legitimacy.

\subsection{Sectarian Politics}

Sectarian politics included communal violence and marginalization of Sunni Arabs from power and politics. Following the occupation of Iraq, the Coalition de-Baathified both civil and military sectors depriving some 500,000 Iraqis, mostly Sunni Arabs, of their livelihoods almost overnight. ${ }^{850}$ The removal of Sunni Arabs from both military and civil sectors paved the way for the Shiites and Kurds to replace them. ${ }^{851}$ Filling the state institutions with them exacerbated the group grievances of the Sunni communities. As a result, both the newly formed government and

\footnotetext{
${ }^{849}$ Lister, "Profiling the Islamic State," 8. Those five groups included Jaish al-Taifa al-Mansurah; Katbiyan Ansar Al-Tawhid wal Sunnah, Saray al-Jihad Group, al-Ghuraba Brigades, and al-Ahwal Brigades.

${ }^{850}$ The number included some 400,000 employees of the security and some 100,000 employees of the civil sectors. For more detail see Eisenstadt and White, "Assessing Iraq's Sunni Arab Insurgency," 3; Peter Galbraith, The End of Iraq: How Americans Incompetence Created a War Without End? (New York: Simon \&Schuster, 2006), 119;

${ }^{851}$ Liz Sly, "The Hidden Hand Behind the Islamic State Militias? Saddam Hussein's," The Washington Post, April 04, 2015 (https://www.washingtonpost.com/world/middle_east/the-hidden-hand-behind-the-islamic-state-militantssaddam-husseins/2015/04/04/aa97676c-cc32-11e4-8730-4f473416e759 story.html).

Tom Porter, "ISIS: Five U.S. Mistakes Which Led to the Rise of Islamic State," International Business Times, June 11, 2015 (http://www.ibtimes.co.uk/isis-five-us-mistakes-which-led-rise-islamic-state-1505642).
} 
its security force found little support among Sunni communities. According to some US army trainers in Iraq, only people in Shiite-dominated greater Baghdad supported the IAF, whereas, in the surrounding "Baghdad belt" which has a Sunni majority, the ISF could not function without the help of Shiite militiamen. ${ }^{852}$ The ISF's reliance on the Shiite militia groups mutually intensified the Sunni grievance, rather than helping the security of the country. The excluded Sunnis viewed the Shiite-led armed force and its reliance on Shiite militia groups as a sectarian agenda for eliminating Sunnis from the political sphere of Iraq entirely. ${ }^{853}$

The removal of Sunnis from power was both the result of wrong information Americans received from Shiite exiles and the Coalition's paranoia of the Saddam regime's remnants. Although the Shiite-led government and the Coalition tried to avoid blaming the Sunnis publicly as the problem, Sunni Arabs, influenced by the anti-Baathist environment of the post-Saddam Iraq, were treated as Baathists. Discrimination of Sunni Arabs was apparent at all levels of Iraqi society. This environment can be well understood through the experience of many former government employees such as Ismail Muhammad Juwara, a former midlevel employee of Iraq's Mukhabarat, the intelligence services who was humiliated by his Shiite countrymen. ${ }^{854}$ According to a Washington Post report, a clerk at one bank where Juwara held an account, for instance, called him a dog when he went to withdraw funds. The clerk told him "he should go to Saddam to ask for his money." ${ }^{855}$ In an interview with the Washington Post in January 2004, Juwara expressed his situation as "...We had dreams. . . Now we are the losers. We lost our positions, our status, the [economic] security of our families, stability. Curse on the Americans. Curse on them." ${ }^{\$ 856}$

\footnotetext{
852 Zucchino, "Why Iraqi Army Can’t Fight, Despite \$25 Billion in U.S. Aid, Training."

${ }^{853}$ See Charles Recknagel, "What Drives Sunni Anger in Iraq?" Radio Free Europe, June 23, 2014 (http://www.rferl.org/a/iraq-sunni-anger-causes/25432218.html).

${ }_{854}^{85}$ Baram, Who Are the Insurgents? 5.

${ }^{855}$ Ibid.

${ }^{856}$ Ibid.
} 
The anti-Sunni politics led Iraq towards communal disputes and sectarian attacks on Sunni communities extended all around Iraq over time. By 2006 and 2007, for instance, Sunnis living in Baghdad were driven out of much of the city by Shiite-controlled security forces. ${ }^{857}$ According to a US embassy cable in September 2007: "Sunnis have largely fled to outlying areas [of Baghdad] or have been concentrated into small enclaves surrounding by Shia neighborhoods." ${ }^{858}$ Further evidence shows that by 2005, the Mahdi Army of Moqtada al-Sadr initiated a total sectarian cleansing of Baghdad's Sunni and mixed neighborhoods. ${ }^{859}$ By the end of 2006, the Mahdi Army gained sectarian dominance over the previously advantaged Sunnis in multiple areas of the capital city. The majority of Baghdad's neighborhoods were mixed in 2003, but by 2008 these neighborhoods were Shia occupied. ${ }^{860}$ Reports by international organizations including the United Nations, Amnesty International, Human Rights Watch and others show that following the defeat of Saddam Hussain Sunni communities became a constant target of forced displacement, kidnapping, abduction, killing and looting by Shiite militia groups. ${ }^{861}$ As the violence peaked, Maliki was selected as the Prime Minister in a US-negotiated process in April 2006, who

\footnotetext{
${ }^{857}$ Cockburn, The Rise of Islamic State, 70.

${ }^{858}$ Ibid.

${ }^{859}$ John Hagan, Joshua Kaiser, Anna Hanson, Patricia Parker, "Neighborhood Sectarian Displacement and the Battle for Baghdad: A Self-Fulfilling Prophecy of Fear and Crimes Against Humanity in Iraq," Sociological Forum 30(3), 2015: 680 .

${ }^{860}$ Hagan et al., "Neighborhood Sectarian Displacement and the Battle for Baghdad," 681.

861 "Country Information and Guidance Iraq: Sunni (Arab) Muslims," Government of UK, August 2016: 23-33 (https://www.gov.uk/government/uploads/system/uploads/attachment data/file/565850/CIG-Iraq-Sunnis-v1-August2016.pdf); "Joint Written Statement Submitted by the International Youth and Student Movement for the United Nations..." UN General Assembly, Human Rights Council, June 7, 2016 (http://www.ecoi.net/file_upload/1930_1467890015_g1611379.pdf); "The State of the World's Human Rights," Amnesty International Report 2015/16, Iraq: 194-197 (https://www.amnesty.org/download/Documents/POL1025522016ENGLISH.PDF); Lahib Higel, "Iraq's Displacement Crisis: Security and Protection," Minority Rights Group International, March 2016 (http://minorityrights.org/publications/iraqs-displacement-crisis-security-and-protection/); "Security Situation in Baghdad-The Shia Militias," Finnish Immigration Service, April 29, 2015 (http://www.migri.fi/download/61225 Security_Situation in Baghdad The Shia_Militias_29.4.2015.pdf?ad032df6eb3dd488); "Iraq: Possible War Crimes by Shia Militia," Human Rights Watch, January 31, 2016, (https://www.hrw.org/news/2016/01/31/iraq-possible-war-crimes-shia-militia);
} 
exacerbated the already growing sectarian divide and violence. ${ }^{862}$ Thus, de-Baathification at the state level and communal disputes on the society level led to the increasing powerlessness of Sunnis and their marginalization from politics. Moreover, due to the old regime's elimination of potential Sunni rivals to Saddam, Sunnis found themselves without an effective voice in the new government. ${ }^{863}$ The failure of the January 2005 elections in Sunni areas was the consequence of the Sunnis' lack of a unified leadership in Baghdad.

In this situation, an anti-American and anti-Shiite insurgency in Sunni areas emerged to resist and fill the leadership gap in Sunni communities. Following the emergence of those groups, Sunni populations found them with greater influence over the political process than they would have had otherwise. ${ }^{864}$ Therefore, the young angry men, the well-trained members of the former Iraqi armed forces, and local Islamists began trying to find their way to the insurgency as early as mid-2003. ${ }^{865}$ Although some ex-Baathists created, initially, their own underground 'resistance' groups, they were subsequently absorbed into SJGs, particularly the most effective AQI. ${ }^{866}$ For example, high ranking Baathists such as Sib'awi Ibrahim Hasan, Saddam's half-brother, and General Tahir Jalil Habush, ex-chief of the Mukhabarat (Saddam's intelligence services) were

\footnotetext{
${ }^{862}$ Hagan et al., "Neighborhood Sectarian Displacement and the Battle for Baghdad," 681.

${ }^{863}$ See, for example, Robert H. Reid, "Shiites, Kurds Emerge as Winners in Iraq," Associated Press, February 14, 2005 (http://forums.thesmartmarks.com/index.php?showtopic=67001).

${ }^{864}$ Eisenstadt and White, "Assessing Iraq's Sunni Arab Insurgency," 17-18.

${ }^{865}$ Stansfield, Iraq, 168.

${ }^{866}$ Many of the insurgent groups formed by ex-Baathists primarily assumed secular names, such as al-'Awda (The Return), al-Islah (The Reform), Jabhat al-Muqawama (The Resistance Front), al-Qiyada al- 'Amma Li-Jaysh al'Iraq (The General Command of Iraq's Army), and Munazzamat al-Tahrir al-'Iraqiyya (The Iraqi Liberation Organization). Other ex-Baathist groups included insurgents that operated in local-basis such as Kata'ib Salah alDin (Saladin Phalanx), which operated around Ramadi; and Kataib al-Mujahidin (The Jihad Warriors Phalanx), which operated among the Arab population of the ethnically mixed province of Kirkuk. Other groups such as Hizb al-Baaath al-"Arabi al-Ishtiraki (The Baath Arab Socialist Party), which provided training, weapons, and finances to both nationalist and Islamist groups. For ex-Baathist insurgent groups see Baram, Who Are the Insurgents? 6; for the escape of the members of the former army see Michael Eisenstadt and Jeffery White, Assessing Iraq's Sunni Arab Insurgency (Washington D.C.: The Washington Institute for Near East Policy, December 2005), 3; see also Michael Eisenstadt, "Sitting on Bayonets: America's Postwar Challenges in Iraq," The National Interest, Summer 2004: 101-106 (http://nationalinterest.org/article/sitting-on-bayonets-americas-postwar-challenges-in-iraq-468).
} 
involved in providing financial and strategic support to the SJGs while lower-ranking Baathists actively joined jihadi operations. ${ }^{867}$ In addition to the ex-Baathists, there were, at the very least, tens of thousands of 'angry Iraqis' with a deep sense of grievance who joined the SJGs including AQI. ${ }^{868}$ Iraqis that joined SJGs included the Sunni Arabs who had lost a family member, were humiliated, treated roughly, or wrongly detained at the hands of the Coalition and the Iraqi government forces. ${ }^{869}$ While ex-Baathists provided the Iraq-based SJGs with their expertise in areas such as strategy-making, military operations, and finance, 'angry Iraqis' provided manpower to the SJGs.

Moreover, the formation of the government-supported and the Coalition-funded Shiite and Kurdish independent militia brigades enhanced the Sunnis' motivation to join SJGs. The initial purpose of the creation of those militia groups was partly to fill in the security gaps left by the local police and army. ${ }^{870}$ However, the expansion of those militia groups in Sunni areas was interpreted in Sunni communities as the domination of their areas by "other" forces. By the beginning of 2005, some of those militia groups, similar to paramilitary-style brigades, fought alongside official Interior and Defense ministry troops against Iraq's Sunni insurgency; while others operated without official assistance or sanction. ${ }^{871}$ The larger and more established militia groups such as the Shiite Badr Organization and the Kurdish Peshmerga units were tied to Iraq's leading political parties, organized along sectarian lines. ${ }^{872}$ The expansion of these autonomous groups undermined severely the idea of a national security force and a unified government in

\footnotetext{
${ }^{867}$ Baram, Who Are the Insurgents? 6.

${ }^{868}$ Eisenstadt and White, “Assessing Iraq's Sunni Arab Insurgency,” 10.

${ }^{869}$ Ibid.

${ }^{870}$ Lionel Beehner, "Iraq: Militia Groups," Council of Foreign Relations, June 9, 2005 (http://www.cfr.org/iraq/iraqmilitia-groups/p8175).

${ }^{871}$ Beehner, "Iraq: Militia Groups."

${ }^{872}$ Ibid.
} 
Iraq. ${ }^{873}$ The Sunnis considered the militia as a sectarian force, rather than elements of a national army. Operations by the Shiite militia in the Sunni areas were highly suspected by the locals and extended the anti-Shiite sentiments in the Sunni Triangle. This situation provided the emerging SJGs with a great in terms of identifying themselves as a resistance army in Sunni communities where they recruited and created safe houses.

Interviews with captured IS fighters show that the organization used the anti-Shiite rhetoric and the Sunnis' grievances in Iraq as recruiting tactics. According to a 20 -year-old IS fighter, Walid Ismail, who was captured by the Kurdish forces in November 2016, he joined the group because [IS recruiters] told him "We aim to rid you of the Shiites and no one will press you. We will give you food and money. Whatever you want." The former bakery worker added, "We loved [ISIS] because they relieved us from the oppression of the Shiites who branded all Sunnis as terrorists." ${ }^{874}$ Other evidence shows that even members of the Sunni tribal Awakening Movement which emerged as an anti-insurgency force in 2007, due to Maliki's "Shiafication" of Iraq's Armed Forces and therefore his unwillingness to integrate the Awakening members into the IAF, switched side to ISI, the predecessor of IS. According to evidence, by mid-2010, hundreds of the welldisciplined Awakening fighters joined ISI and thousands of them who were still on the Iraqi government payroll, covertly aided the insurgency. ${ }^{875}$

Moreover, tribal sheikhs in Fallujah pledged allegiance to the Islamic State because they considered the Shiite-led IAF units' counterinsurgency operations on their communities as a sectarian war. They asked the Baghdad government to arm the Sunni tribes to fight the insurgency.

\footnotetext{
${ }^{873}$ Beehner, "Iraq: Militia Groups."

${ }^{874}$ Joe Barnes, "Captured ISIS Fighters Reveal Secrete and Brutal Recruitment Tactics," Express, November 30, 2016 (http://www.express.co.uk/news/world/738231/isis-fighters-reveal-terror-group-recruitment-tactics-iraq-syria). 875 Timothy Williams and Duraid Adnan, "Sunnis in Iraq Allied with U.S. Rejoin Rebels," New York Times, October 162010 (http://www.nytimes.com/2010/10/17/world/middleeast/17awakening.html).
} 
When the government rejected their call, the tribal sheikhs joined IS. ${ }^{876}$ Furthermore, the Coalition's efforts to begin a dialogue in 2006 with some non-jihadi particularly ex-Baathist nationalist insurgent groups over a power-sharing mechanism in order to give a more inclusive face to the government, had little practical impact on decreasing group grievance. ${ }^{877}$ Data shows that group grievances continued in Iraqi Sunni communities even one decade after the end of Saddam's era. According to an Iraqi police officer who served in Mosul and fled the city when ISIS attacked in 2014, “[the war is] sectarian. They [Sunnis] don't want us to work for them... We asked why they wouldn't agree to work with us. Why? They said we are not humans. We are monsters." ${ }^{\prime 78}$ Research on the sectarian roots of the post-Saddam Iraq indicates that Sunni Arabs self-considered themselves as the victims of the US-sponsored and Shiite-dominated political process. They also believed that both the Coalition and the Iraqi government viewed them as the outsiders to the political process. Therefore, the only force they relied on was the Iraq-based Sunni SJGs that legitimized itself as a sectarian resistance force. This situation developed a condition of 'weness' against the 'other' in Sunni communities under which the development of the insurgency into a Sunni jihadi organization was facilitated.

\subsection{External Intervention}

The US invasion of Iraq was the main cause of both state collapse in Iraq and the emergence of IS which is broadly discussed in chapter V. State collapse in Iraq, as a consequence of the US invasion, paved the way for regional powers' intervention in this country which exacerbated Shiite

\footnotetext{
876 “ISIL Wins Support From Iraq’s Sunni Tribes," Aljazeera, June 4, 2015 (http://www.aljazeera.com/news/2015/06/sunni-sheiks-pledge-allegiance-isil-iraq-anbar-150604074642668.html).

877 Cordesman, Iraq's Insurgency and the Road to Civil Conflict, 239.

${ }^{878}$ Fordham, "Iraq's Army is Ineffective Against Islamist Insurgents."
} 
vs. Sunni politics. External intervention, in this part, refers specifically to the intervention of regional powers in Iraqi affairs.

Following the collapse of the Iraqi state in 2003, almost all regional powers in the Middle East tried to have their share in the post-Saddam political process. Among others, Iran and Saudi Arabia's role was decisive. Iran and Saudi Arabia's competition for influencing post-Saddam Iraqi politics exacerbated sectarian confrontation and violence among Shiites and Sunnis, providing the main condition under which the Iraqi insurgency was primarily formed and ultimately developed into IS. Iran benefited significantly from the collapse of Saddam's regime by expanding its relations with both the Shiite-led government and pro-Iranian Shiite religious figures such as Moqtada al-Sadr. ${ }^{879}$ Thus Shiite politics in Baghdad was in favor of Iran which largely influenced both the Shiite-dominated government and Shiite militia groups. ${ }^{880}$ Saudi Arabia felt isolated in Baghdad. Prior to the US invasion, the Saudi government had developed the idea of a regime change in Iraq, to topple the anti-Saudi Baathist regime replacing it with pro-Saudi Sunni Iraqi Generals. ${ }^{881}$ The Kingdom was shocked with the rise of Shiite-led politics in Iraq which favored Iran the most. Therefore, from the outset of the new era in Iraq, Saudi politicians massively invested in balancing Iran's growing influence in Iraq. The Saudi government took a variety of measures including diplomatic pressures on both the US and the Iraqi government to provide Sunnis with more opportunities in the Iraqi politics. Unlike Iran which created a "mini-Iran" in eastern parts of Iraq and clearly supported the Shiite rebellion in the early years after the invasion, Saudi Arabia's involvement in Iraq in the early years following the US invasion was limited mainly

\footnotetext{
${ }^{879}$ Nicholas Krohley, "Moqtada al-Sadr's Difficult Relationship with Iran," Hurst, August 7, 2014 (http://www.hurstpublishers.com/moqtada-al-sadrs-difficult-relationship-with-iran/).

${ }^{880}$ Max Fisher, "How the Iranian-Saudi Proxy Struggle Tore Apart the Middle East," New York Times, November 19, 2016 (http://www.nytimes.com/2016/11/20/world/middleeast/iran-saudi-proxy-war.html).

${ }^{881}$ Scott MacLeod, “The Saudi Push for an Iraq Coup,” Time Magazine, January 16, 2003 (http://content.time.com/time/world/article/0,8599,408784,00.html).
} 
to diplomatic activities. ${ }^{882}$ But as time passed, the Kingdom's involvement became more direct, concentrating on sectarian politics in favor of Sunni Arabs. Saudi Arabia also invested in antiShiite sentiments in Sunni-dominated areas, motivating Sunnis to resist the expansion of a Shiitedominated government. After the creation of IS, some US government elements claimed the Saudi's support of IS. A Hillary Clinton email, leaked by the WikiLeaks in 2016, indicates the Secretary of States' concern about the Saudis and Qataris' "financial and logistical support" of ISIL, however, Saudi Arabia's direct hand in creating IS or even AQI is not proven by reliable evidence. ${ }^{883}$ The Saudi government has rejected any links with SJGs in Iraq, characterizing them as opposed to the Kingdom. ${ }^{884}$ However, no informed observer can reject the fact that in fueling sectarian politics in Iraq Saudi Arabia played a significant role. ${ }^{885}$ The anti-Shiite sectarian politics the Saudis played in Iraq contributed to the emergence and expansion of Iraq-based SJGs such as AQI and ISIS which self-described themselves as the only defenders of the Sunnis on the ground. ${ }^{886}$ Saudi Arabia and Iran's intervention in post-Saddam Iraq was part of the two regional powers' long struggle for supremacy in the Middle East. The defeat of Saddam who was hostile to both Saudi Arabia and Iran upended the regional balance of power. ${ }^{887}$ Iran achieved strong influence in Baghdad and also wielded Shiite militias to control Iraqi streets to undermine the American-led occupation. ${ }^{888}$ Saudi Arabia, by contrast, sought to match Iran's reach by fostering

\footnotetext{
${ }^{882}$ Ehsan Ahrari, "Saudi Arabia and Iran in Iraq Fix," Asia Times, December 20, 2006 (https://www.worldsecuritynetwork.com/Broader-Middle-East-Iran-United-States/ehsan-ahrari/Saudi-Arabia-andIran-in-Iraq-fix).

${ }^{883}$ Gabriel Samuel, "Julian Assange: ISIS and Clinton Foundation are both Funded by Saudi Arabia and Qatar," The Independent, November 4, 2016 (http://www.independent.co.uk/news/people/julian-assange-clinton-foundation-isissame-money-saudi-arabia-qatar-funding-a7397211.html).

${ }_{884}^{8 h r a r i, ~ " S a u d i ~ A r a b i a ~ a n d ~ I r a n ~ i n ~ I r a q ~ F i x . " ~}$

${ }^{885}$ Simon Tisdall, "WikiLeaks's Cables: Saudi Arabia Rated Bigger Threat to Iraq Stability than Iran," the Guardian, December 5, 2010 (https://www.theguardian.com/world/2010/dec/05/wikileaks-cables-saudi-meddlingiraq).

${ }^{886}$ Steve Clemons, 'Thank God for the Saudis': ISIS, Iraq and the Lessons of Blowback," The Atlantic, June 23, 2014 (https://www.theatlantic.com/international/archive/2014/06/isis-saudi-arabia-iraq-syria-bandar/373181/).

${ }^{887}$ Fisher, "How the Iranian-Saudi Proxy Struggle Tore Apart the Middle East."

${ }^{888}$ Ibid.
} 
sectarianism and allying itself with Iraqi ex-Baathist and Islamist Sunnis who were in search of a unifying force to organize and lead their anti-Shiite and anti-Occupation sentiments. ${ }^{889}$ ISI and ultimately IS's emergence was a response to this need.

Following the US invasion of Iraq, Iran started its direct intervention in Iraqi affairs by expanding its relations with the Shiite-led government in Baghdad. The two major Shiite parties (i.e. the Supreme Council for Islamic Revolution in Iraq which renamed itself into Islamic Supreme Council of Iraq (ISCI) in 2007 and the Islamic Dawa Party) were deeply influenced by the Iranian establishment. ISCI was founded with the Iranian Ayatollas' support in Iran in 1982, and the Dawa received big support from the Iranians against Saddam's government. ${ }^{890}$ In addition to its influence within the Shiite-led government, Iran also controlled the Shiite extremist groups whose main purpose was to create a pro-Iranian Islamized government in Baghdad. The major Shiite rebellion group, the Sadr Movement and its Mahdi Army which planned to Islamize the Iraqi government were profoundly pro-Iranian. ${ }^{891}$ Moreover, the Supreme Council for the Islamic Revolution in Iraq's armed wing, the Badr Organization, was supported and influenced by Iran. ${ }^{892}$ Iran was believed by regional intelligence agencies to have armed and trained as many as 40,000 Iraqis to prevent a retreat of Shiite control. ${ }^{893}$ Even though US officials warned Iran to keep its agents out of Iraq, classified US intelligence cited in the press indicates that Iran kept trying to

\footnotetext{
${ }^{889}$ Ibid.

${ }^{890}$ Shaul Bakhash, Reign of Ayatollahs: Iran and the Islamic Revolution (New York: Basic Books, 1984, 233; Robin Wright, Sacred Rage: The Wrath of Militant Islam (New York: TOUCHSTONE, 2001), 124;

${ }^{891}$ See Stansfield, Iraq, 176-178; Ibrahim al-Marashi, "Iraq: the Reinvention of Muqtada al-Sadr," Aljazeera, March 9, 2016 (http://www.aljazeera.com/indepth/opinion/2016/03/iraq-reinvention-muqtada-al-sadr160309061939234.html); "Profile: Moqtada al-Sadr," BBC, January 19, 2012 (http://www.bbc.com/news/worldmiddle-east-12135160).

${ }^{892}$ Steven Simon and Ray Takeyh, "Iran’s Iraq Strategy,” The Washington Post, May 21, 2006 (http://www.washingtonpost.com/wp-dyn/content/article/2006/05/19/AR2006051901761.html).

${ }^{893}$ Simon and Takeyh, "Iran’s Iraq Strategy."
} 
exert direct influence in Iraq. ${ }^{894}$ In addition to supporting domestic Shiite extremists, Tehran also deployed to Iraq a large number of the Revolutionary Guard's Qods Force, ${ }^{895}$ as well as, officers from the Ministry of Intelligence and National Security and representatives of the Lebanese Hezbollah in the first three years following the US invasion. ${ }^{896}$ Iranian personnel in Iraq monitored, mainly, the movement of the Coalition forces, tended weapons caches, facilitated cross-border travel of Shiite clerics, smuggled munitions into Iraq and recruited individuals as intelligence sources ${ }^{897}$ Beyond that, Iran attempted to expand a Shiite coalition in the region by dominating Iraq. This effort was considered by Jordan's King Abdullah as Iran's attempt to form a "Shiite Crescent" among Iran, Iraq, Syria and Lebanon. ${ }^{898}$ Iran's influence within the Shiite-dominated government in Iraq, its sway over Shiite militias and its considerable paramilitary presence in Iraq turned Iran into a key player in Iraqi politics giving Tehran leverage even at the international level. Iran used, for example, its Iraqi card openly "in its nuclear stalemate game with the Washington., $\$ 899$

Saudi Arabia could neither tolerate an emerging pro-Iran rebellion in Iraq nor a highly Iranleaning Shiite regime in Baghdad. Therefore, Saudi Arabia's expanding involvement, and its support of the Sunni insurgency, was its war on Iran. It sought to check the sectarian balance of power in Baghdad by expanding its influence in Iraq. ${ }^{900}$ The Saudis' considered, initially, two approaches in influencing Iraqi politics, a direct and an indirect approach. Saudi Arabia's direct approach was mainly formal and based on the inclusiveness of Sunnis in Iraqi politics and

\footnotetext{
${ }^{894}$ Sharon Otterman, "Iraq: Iran's Involvement," Council on Foreign Relations, May 15, 2003 (http://www.cfr.org/iraq/iraq-irans-involvement/p7733).

${ }^{895}$ Qods Force is highly professional force specialized in assassinations and bombings.

${ }^{896}$ Simon and Takeyh, "Iran's Iraq Strategy."

${ }^{897}$ Ibid.

${ }^{898}$ Cordesman, Iraq's Insurgency and the Road to Civil Conflict, 131.

${ }^{899}$ Simon and Takeyh, "Iran's Iraq Strategy."

${ }^{900}$ Simon Henderson, "The Battle for Iraq is a Saudi War on Iran," Foreign Policy, June 12, 2014 (http://foreignpolicy.com/2014/06/12/the-battle-for-iraq-is-a-saudi-war-on-iran/).
} 
supporting their central role in Baghdad. In this context, the Saudi establishment tried hard to pressure the Americans to bring Sunnis together by giving them leadership roles in Baghdad. ${ }^{901}$ The Kingdom's practical purpose was to "keep ex-Baathists involvement in a power-sharing arrangement. $" 902$ In addition to its direct approach, the Saudis also drew on indirect measures to influence Iraqi politics by expanding Salafi-jihadism/Wahhabism among Sunni communities as a response to the Iranian government's efforts to project its ideology in the region. ${ }^{903}$ Wahhabism, born in Saudi Arabia, is traditionally used by the Saudi state in Muslim countries in order to encourage pro-Saudi sentiments. For example, from the mid-1980s onward, the Saudi state actively expanded Wahhabism in the Muslim world. Since then, the Saudi establishment has justified the support of any SJG as the support of Muslims abroad. ${ }^{904}$ A Saudi Intelligence official's remark on the Kingdom's encouragement of young Muslims to fight for Islam clearly indicates the Saudi sate's conventional usage of jihadism as a foreign policy measure:

"We encouraged our young men to fight for Islam in Afghanistan. We encouraged our young men to fight for Islam in Bosnia and Chechnya. We encouraged our young men to fight for Islam in Palestine. Now we are telling them you are forbidden to fight for Islam in Iraq, and they are confused." 905

Thus, regardless of its prevention of any extremist activities within its territory, there have been many extremist movements either supported by the Saudi government and its clergy or led by Saudi Wahhabis all around the Muslim world. ${ }^{906}$ Therefore, despite a lack of data that proves the

\footnotetext{
${ }^{901}$ Cordesman, Iraq's Insurgency and the Road to Civil Conflict, 211.

902 Banafsheh Keynoush, Saudi Arabia and Iran: Friends or Foes? (New York: Palgrave Macmillan, 2016), 178

${ }^{903}$ Tisdall, "WikiLeaks's Cables: Saudi Arabia Rated Bigger Threat to Iraq Stability than Iran."

${ }^{904}$ Robert Windrem, "Saudi Arabia's Ambitious al-Qaida Fighter," NBC News, 11 July 2005 (http://www.nbcnews.com/id/8304825/ns/dateline_nbc/t/saudi-arabias-ambitious-al-qaida-fighter/\#.WG_4SvkrJnI).

905 Windrem, "Saudi Arabia's Ambitious al-Qaida Fighter."

906 Nawaf Obaid and Anthony Cordesman, Saudi Militants in Iraq: Assessment and Kingdom's Response

(Washington D.C.: Center for Strategic and International Studies, September 19, 2005), 15.
} 
direct involvement of the Saudi state in the formation of IS, the emergence, and expansion of SJGs in Iraq was broadly justified by Saudi Arabia's powerful clergy. For example, in October 2004, several clerics in Saudi Arabia defined joining the Iraq-based SJGs as "the duty of every Muslim." ${ }^{907}$ Following this call, on November 5, 2004, twenty-six prominent Saudi clerics, including Sheikh Salman al-Audah and Sheikh Nasser al-Omar, signed a fatwa saying that Iraqis should rise up and oppose the Americans in their country. Some young Saudis considered the fatwa as a clear call for jihad in Iraq. ${ }^{908}$ This call motivated thousands of Saudi jihadis to enter Iraq and join the anti-Shiite and anti-American insurgency which greatly served the expansion of the Sunni insurgency and, thus, Saudi Arabia's foreign policy in Iraq. ${ }^{909}$ Following the call, more Saudi citizens were encouraged to cross the border into Iraq and join their countrymen who had entered Iraq in early 2003, days before the US invasion. ${ }^{910}$ Although the real figure of the number of Saudis fighting in Iraq is disputed by different sources, ${ }^{911}$ according to some Saudi security officials it was between 2000 and 3000 in the mid-2005. ${ }^{912}$

\footnotetext{
${ }^{907}$ Bryan Bender, "Study Cites Seeds of Terror in Iraq: War Radicalized Most, Probes Find," The Boston Globe, July 17, 2005 (http://irishantiwar.org/archives/news/101496.html).

908 Obaid and Cordesman, Saudi Militants in Iraq, 15.

${ }^{909}$ For the number of Saudi militant Islamist entering Iraq see Thomas Hegghammer, 'Saudis in Iraq: Patterns of Radicalization and Recruitment,' Cultures and Conflicts 2008, 11.

${ }^{910}$ From March 2003 onward, there were regular media reports about foreign fighters, including Saudis, trickling in to Iraq. For details, see Neil MacFarquhar, "For Arabs, New Jihad is in Iraq," New York Times, April 2, 2003 (http://www.nytimes.com/2003/04/02/world/a-nation-at-war-the-islamic-world-for-arabs-new-jihad-is-in-iraq.html; Mark Huband, "Saudis in Iraq 'Preparing for a Holy War'," Financial Times, August 18, 2003 (http://www.informationclearinghouse.info/article4477.htm); Faiza Saleh Ambah, "Saudi Fighters Cross Border to Kill Infidels," Washington Times, August 31, 2003 (http://www.washingtontimes.com/news/2003/aug/31/20030831121933-2108r/).

${ }^{911}$ See, for example, Obaid and Cordesman, Saudi Militants in Iraq, 6; Shaista Aziz, "Saudi Fighters 'Join Resistance' in Iraq," Al-Jazeera, October 28, 2003 (http://www.aljazeera.com/archive/2003/10/2008410141418821563.html).

${ }^{912}$ Hegghammer, "Saudis in Iraq," 11.
} 


\section{Poor Authority}

Lack of an effective and legitimate security apparatus was another determinant aspect of state fragility in post-Saddam Iraq which developed a favorable condition for the emergence of IS. Although Iraq's armed forces in the early 2000s were down to about $40 \%$ of their 1991 Gulf War levels, they remained the most effective force in the Gulf region until the US invasion. ${ }^{913}$ The Iraqi armed force was regularly organized in two main sectors, armed forces which included the regular army, the Republican Guard, and the Special Republican Guard, and security forces which included the police and the intelligence services. ${ }^{914}$ It is believed that before the US invasion, the 400,000 Iraqi armed forces were capable of securing and defending Iraq, and had a sufficient monopoly over the use of physical force in the country. ${ }^{915}$ Following the defeat of Saddam's regime, all essential components of the state power, including its army, police and intelligence disintegrated faster than it was predicted by the Americans. Following the disintegration of Iraq's armed forces, the Coalition confronted three security tasks in Iraq. The first task was to restore order and neutralize insurgents and terrorists. The second task was to rebuild Iraqi defense and security sectors, which could eventually take responsibility for Iraq's security. And the third task was to reconstruct and reform Iraq's defense and security institutions, such as national security management institutions, the interior and defense ministries, and the intelligence services. ${ }^{916}$ More importantly, the CPA leadership assumed that, in order to build a new and apolitical armed force, it had to disband Iraq's old armed force from top to bottom, in the first place. ${ }^{917}$ Therefore, the

\footnotetext{
${ }^{913}$ For the organization, equipment, function and capability of Iraq's Armed Forces in early 2003 see, Otterman, "Iraq: Iraq's Pre-War Military Capabilities," Otterman, "Iraq: Iraq's Pre-War Military Capabilities."

${ }^{914}$ See Otterman, "Iraq: Iraq's Pre-War Military Capabilities;" Rathmell et al. Developing Iraq's Security Sector, 42-56, 61-64.

${ }^{915}$ Otterman, "Iraq: Iraq's Pre-War Military Capabilities."

${ }^{916}$ Rathmell, et al., Developing Iraq's Security Sector, 1.

${ }^{917}$ Flibbert, "The Consequences of Forced State Failure in Iraq," 67; Ronsiny, "The Rise and Demise of the IS Caliphate," 95.
} 
CPA disbanded the Iraqi Army and all defense institutions from the scratch. ${ }^{918}$ Following the dissolution of Iraq's armed and security forces, the country experienced a severe security vacuum which the CPA aimed to fill by building new military and security units. But the process of recruiting, training, and deploying the Iraqi security forces and reconstructing the structure of the security institutions was too slow in the face of a fast-growing insurgency in the first years after the invasion. The Coalition decided to confront the situation by direct military operations. This short-term approach was more outrageous than helpful for the situation. The Coalition mainly operated in large cities and the Iraqi forces were ineffective in controlling the expanding ungoverned areas. The Fallujah Brigade, for instance, was created in April 2004 to keep the insurgents out of the city. The Brigade was disbanded four months later when the US marines found out that it was ineffective in fighting the insurgents for the long-term and were making more trouble than contributions to Iraqi security. ${ }^{919}$

The IAF's ineffectiveness was the outcome of a series of shortages among which lack of leadership, poor Ministry of Defense (MoD) administrative capacity, and lack of combat support services were the most serious ones. ${ }^{920}$ These shortages made the IAF both incapable of controlling Iraq's territory and fragile against anti-government elements. The IAF did not have effective control in the Sunni Triangle in which the seeds of IS were planted. Security assessment reports on the post-Saddam security sector show by the time the CPA handed authority over to the Iraqi

\footnotetext{
${ }^{918}$ Coalition Provisional Authority. Order 2: Dissolution of Entities with Annex A. 2003; Zinn, "Consequences of Iraqi De-Baathification," 3; Bob Woodward, State of Denial: Bosh at War, Part III, (New York: Simon \&Schuster, 2006), 194-195; Jane Arraf, "U.S. Dissolves Iraqi Army, Defense and Information Ministries," CNN, May 23, 2003 (http://www.cnn.com/2003/WORLD/meast/05/23/sprj.nitop.army.dissolve/).

Sebastian Usher, "Baathist Mistakes Corrected Amid Concern,” BBC News, January 12, 2008 (http://news.bbc.co.uk/2/hi/middle_east/7185276.stm).

919 Alissa J. Rubin, "Ineffective Iraqi Force in Fallujah Disbanded," Los Angeles Times, September 11, 2004 (http://articles.latimes.com/2004/sep/11/world/fg-fallouja11).

${ }^{920}$ Michael Knights, The Future of Iraq's Armed Forces (Baghdad: al-Bayan Center for Planning and Studies, 2016), 18-19 (http://www.bayancenter.org/en/wp-content/uploads/2016/03/The-future.pdf).
} 
Interim Government on June 28, 2004, it was clear that the Coalition had made little progress in its first task of restoring order and neutralizing the insurgency. Insurgency was growing promptly with the number of its domestic members reaching at 12,000 to $20,000,{ }^{921}$ and its foreign jihadi members reaching 3,000 by late $2004 .{ }^{922}$ By the time ISI began growing stronger in 2012, the IAF was a "brittle force which could neither control Iraq nor resist any major blow." 923

Failure in fulfilling the first task slowed down the Coalition's second and third tasks which included the rebuilding of Iraq's armed forces and the reconstruction of its defense and security institutions. The CPA's initial plan was to rebuild and reform four major institutions of Iraq's security sector: a national security committee to coordinate various security-related activities, the defense sector which included the Ministry of Defense (MoD) and the Iraqi Armed Forces (IAF), the security sector which included the Ministry of Interior and the Police Forces including affiliated institutions, and the justice sector which included judicial and prisons system. ${ }^{924} \mathrm{~A}$ careful assessment of development in these sectors shows that little success was achieved in the first decade following the US invasion.

National Security Committee: In June 2004, CPA started helping Iraq's political leaders establish a national security committee called the Ministerial Committee on National Security (MCNS). This committee was built to engage in the policy development of the security sector and to consult Iraq's security with the IGC. ${ }^{925}$ But MCNS's existence was not as effective as expected

\footnotetext{
${ }^{921}$ Documented in Michael Eisenstadt and Jeffrey White, “Assessing Iraq's Sunni Arab Insurgency,” (Washington D.C.: The Washington Institute for Near East Policy, 2005), 7-8; see also interview with General John Abizaid, Commander of the U.S. General Command in Iraq on Face the Nation, CBS News, June 26, 2005: 3

(http://www.cbsnews.com/htdocs/pdf/face 062605.pdf).

${ }_{922}$ Obaid and Cordesman, Saudi Militants in Iraq, 4-7.

${ }^{923}$ Knights, The Future of Iraq's Armed Forces, 20-21

${ }^{924}$ Rathmell, et al., Developing Iraq's Security Sector.

${ }^{925}$ Ibid., 6.
} 
due to the lack of a sufficient domestic armed force and because almost all military operations were conducted by the Coalition. ${ }^{926}$

Defense Sector: In the early years following the occupation of Iraq, the defense sector developed very slowly. The rebuilding of the defense sector suffered, in general, from three managerial, political and contextual miscalculations. In terms of management, the CPA did not balance the development of MoD institutions and the IAF with the latter developing faster than the former. ${ }^{927}$ This made the civil management of the IAF difficult. Politically, a weak MoD paved the way for the sectarian-based recruitment in the army's separate divisions which were largely commanded by Shiite officers. This, in turn, challenged the creation of a representative force that would reflect the ethnic, religious, and sectarian makeup of Iraq. And contextually, the primary policy of building the IAF did not consider the actual security problems of the post-Saddam Iraq. The Coalition's primary purpose was to create a classic army for external defense, while the main Iraqi problem was internal violence and insurgency. ${ }^{928}$ Lack of a primary focus on internal threats significantly benefited the growing insurgency. Since IAF was initially trained to fight an external enemy, it mainly failed to perform consistently well when called upon to fight insurgents alongside Coalition forces. ${ }^{929}$ Although the focus was revised in spring 2004 with counterinsurgency training being added to the overall program, it was quite late. The Iraq-based insurgency had expanded throughout the country by that time. ${ }^{930}$ With IAF incapable of preventing the growth of insurgency, the Coalition created another military force named the Iraqi Civil Defense Corps (ICDC) in early 2004. ICDC's operations overlapped with the police missions while its personnel was trained as

\footnotetext{
926 Ibid..

${ }^{927}$ Ibid., 1; Rick Barton and Bathsheba Croker, Progress or Peril? Measuring Iraq's Reconstruction (Washington D.C.: Center for Strategic and International Studies, September 2004), 27.

${ }_{928}$ Rathmell, et al., Developing Iraq's Security Sector, 36.

929 Ibid., 41.

${ }^{930}$ Eisenstadt and White, “Assessing Iraq's Sunni Arab Insurgency," 7-8; Bruce Hoffman, Insurgency and Counter Insurgency in Iraq, (Santa Monica, Arlington, Pittsburgh: RAND, June 2004).
} 
soldiers, not policemen. ${ }^{931}$ Thus, the three managerial, political and contextual gap, in addition to the Coalition's lack of a relevant response to the security problems, widened the security vacuum which a group such as IS was preparing to fill.

Security Sector: Reconstruction of the Ministry of Interior (MoI) and the Police force in early years following the occupation had a mixed result. Unlike the defense sector and the Intelligence agencies, the MoI was not dissolved through the CPA's de-Baathification. Because the Coalition's plan was to hand over responsibility for policing and internal security to Iraqi institutions as soon as feasible. ${ }^{932}$ The Saddam-era Interior Ministry had a broad range of security and administrative functions, most of which was retained in the new MoI. ${ }^{933}$ By July 2004, the police recruiting, training, equipping, and infrastructure development programs were making progress, with the actual number of serving police personnel reaching $120,000 \cdot{ }^{934}$ But despite its personnel reaching a considerable number, the Iraqi Police force suffered from a lack of a uniform vision about Iraq's security priorities and the lack of capacity to provide a national security agenda. The reason was that the Coalition's Police advisors in Iraq spent most of their time in managing MoI and police operations on a day to day basis, rather than engaging in institutional development and capacity-building of the security apparatus. ${ }^{935}$ Therefore, failure in delivering urban and rural policing was the result of the ill-managed and underqualified Police system. ${ }^{936}$ Moreover, due to the Mol's failure in conducting its border, population, and weapon control tasks, both domestic and cross-border criminality increased in early years after the occupation. ${ }^{937}$ This, in turn, eased

\footnotetext{
${ }^{931}$ Rathmell, et al., Developing Iraq's Security Sector, 41.

932 Ibid., 42.

${ }^{933}$ Only the responsibility for prisons was removed and handed to the Ministry of Justice. Conversely, the previous dual MoI-MoD control over border security was resolved with the creation of a Department of Border Enforcement within the MoI. See Rathmell, et al., 42.

${ }^{934}$ Rathmell, et al., Developing Iraq's Security Sector, 46.

${ }^{935}$ Ibid., 53-4.

${ }^{936}$ Ibid., 53-4.

${ }^{937}$ Ibid., 55-56.
} 
the infiltration of international jihadis into Iraq and helped them to create sanctuaries within Iraq. Lack of an effective border control force was evident from the widespread smuggling, infiltration of transnational jihadis, and other cross-border trafficking such as returning refugees from Iran and elsewhere. ${ }^{938}$ To deter arms smugglers and foreign militants, the Americans increased the patrolling of Iraq's borders in 2004 but the American presence in Iraq's borders did not provide a permanent solution to the problem. ${ }^{939}$ Using the condition of a weak border security force, numerous jihadis from Saudi Arabia, Syria, Jordan, Egypt, non-Arab terrorists from Iran, Afghanistan, and Chechnya infiltrated Iraqi borders unchecked and found shelter and support from the Sunnis, mostly, in the Sunni Triangle. ${ }^{940}$ Iraq's borders remained out of effective state control even after the formation of IS, in $2014 .{ }^{941}$ In 2015 , IS controlled about $700 \mathrm{~km}$ of Iraq's border with Syria, while borders with Saudi Arabia, Jordan, Turkey, Iran, and Kuwait were being managed by these countries in the absence of Iraqi border forces. ${ }^{942}$ Furthermore, following the occupation both the Americans and the MoI failed to guard Iraq's 2,700 identified munitions sites. Parts of those sites were initially looted by the former regime's elements who affiliated with the insurgency in different ways as discussed. Reports show that most explosives and weapons used in attacks against the American forces and Iraqi troops were looted from those storage sites. ${ }^{943}$

\footnotetext{
${ }^{938}$ Steve Negus, "Infiltrate Iraq the Easy Way: Pop Over the Syrian Border," Financial Times, September 27, 2004 (http://www.ft.com/cms/s/0/8b0989b6-1022-11d9-ba62-00000e2511c8.html?ft_site=falcon\&desktop=true);

Rathmell, et al., Developing Iraq's Security Sector, 55.

${ }^{939}$ Eric Schmitt, "The Struggle for Iraq: Infiltration, U.S. Commanders Say Increased Border Patrols are Halting the Influx of Non-Iraqi Guerilla," New York Times, April 20, 2004

(http://www.nytimes.com/2004/04/20/world/struggle-for-iraq-infiltration-us-commanders-say-increased-borderpatrols-are.html).

${ }^{940}$ Schmitt, "The Struggle for Iraq;" Nazhad Khasraw Hawramany , "The Sunni Triangle of Death and Terror," New York Times, September 23, 2004 (http://www.freerepublic.com/focus/f-news/1224093/posts).

${ }^{941}$ Othman al-Mukhtar, "Iraq's Borders Fall Out of Government's Control," al-Arabia, April 8, 2015 (https://www.alaraby.co.uk/english/politics/2015/4/8/iraqs-borders-fall-out-of-government-control).

942 al-Mukhtar, "Iraq's Borders Fall Out of Government's Control."

${ }^{943}$ Eric Schmitt and Lowell Bergman, "The Struggle for Iraq: Munitions; Security at Iraq Munitions Sites is Vulnerable, U.S. Officials Say,” New York Times, September 6, 2003 (http://www.nytimes.com/2003/09/06/world/struggle-for-iraq-munitions-security-iraq-munitions-sites-vulnerableus.html).
} 
Regardless of their vulnerability to the insurgency, those storage sites remained poorly secured for years. The weapons control section of MoI which was assigned to control Iraq's vast ammunition storage sites failed significantly in fulfilling its task because of the lack of force and resources. ${ }^{944}$ Overall, lack of a sufficient development in the security sector, the MOI's failure in managing the country's policing properly, and weak borders and weapons control forces significantly contributed to the extension of ungoverned areas and borders which, in turn, provided a favorable condition for the rise and expansion of the Iraq-based insurgency and its development into IS.

Intelligence Services: The rebuilding of a coordinated Iraqi intelligence apparatus was excluded from the post-Saddam state-building program. When a coordinated intelligence was critical to the success of both the counterinsurgency campaign and the fight against organized crime, the CPA delayed the establishment of a uniform Iraqi intelligence, assigning it to a future Iraqi government. ${ }^{945}$ The CPA believed that the MoI and MoD's intelligence capabilities would be sufficient in collecting their needed information. Furthermore, the American 1st Armored Division in Baghdad had created an Iraqi intelligence cell of its own, which supported the Coalition's intelligence efforts. ${ }^{946}$ Evidence shows that the exclusion of rebuilding Iraq's central policing system caused an intelligence gap, in which the insurgent and jihadi groups easily established their networks and operational cells. ${ }^{947}$ Those cells were multinational and composed of both domestic and international jihadis and, therefore, could be considered as the nucleuses of the establishment of a transnational jihadi organization in Iraq ${ }^{948}$ Meanwhile, the remnants of

\footnotetext{
944 Rathmell, et al., Developing Iraq's Security Sector, 56.

945 Ibid., 62.

946 Ibid., 62.

${ }^{947}$ A typical insurgent cell in Iraq consisted of 5 to 10 insurgents. However, CIA used cell in Iraq interchangeably with unit which consisted of 20 to 100 combatants. See Malcolm W. Nance, The Terrorists of Iraq: Inside the Strategy and Tactics of the Iraq Insurgency 2003-2014, Second Edition (Florida: CRC Press, 2015$), 108$.

948 Joshua Partlow, "Iraqi Officials Say Insurgent Cell Bombed Shiite Shrine," Washington Post, June 29, 2006 (http://www.washingtonpost.com/wp-dyn/content/article/2006/06/28/AR2006062802028.html).
} 
Saddam's intelligence apparatus expanded their underground networks to facilitate the expansion of the Sunni insurgeny. The ex-Baathist intelligence was far ahead of the Coalition in their ability to gather information, facilitate the insurgents' communication and networking, and motivate the population against the Coalition and Baghdad. ${ }^{949}$

\section{Security Gap and the Rise of IS}

Without Iraqi forces being able to take on security tasks, Coalition forces were compelled to police Iraq in ways that were unpleasant to the Iraqi public. ${ }^{950}$ Thus, lack of a sufficient domestic force and the Coalition's direct operations developed a condition of fear and chaos in Iraq, in which the seeds of the Iraq-based insurgency and its transformation into IS was planted. The emergence of IS's predecessors and their long journey towards the formation of a uniform jihadi organization was followed through a three-step process: First, the infiltration of international jihadi groups, particularly Zarqawi's JTJ into Iraq. Second, the emergence of anti-occupation and anti-Shiite domestic SJGs and their interaction with militarily trained ex-Baathists. Third, the interaction of the domestic and international elements of the insurgency and their regrouping into a uniform organization. All three phases of the emergence and development of the Iraq-based insurgency, in fact, took place in the ungoverned areas of the Sunni Triangle.

As early as May 2003, international jihadis, particularly Zarqawi's JTJ, moved into the Sunni Triangle and quickly interacted with domestic Sunni jihadis and ex-Baathists. ${ }^{951}$ Findings show that JTJ and other insurgent elements created their cells and networks in areas which were out of effective governance. Those areas were mainly self-controlled by Sunni tribes that for

\footnotetext{
949 Rathmell, et al., Developing Iraq's Security Sector, 62.

950 Ibid., 3.

${ }^{951}$ Weaver, "The Short, Violent Life of Abu Musab al-Zarqawi."
} 
sectarian reasons facilitated the SJGs' activities. Specific places in the area provided the sanctuaries in which scattered Iraqi insurgent groups interacted and developed into a meaningful organizational structure. Under this condition, Zarqawi managed to absorb both the Islamist and Baathist elements of the insurgency into his organization in order achieve shared tactical and operational objectives. ${ }^{952}$ Thus, AQI became the dominant SJG in Iraq.

The Sunni Triangle, including parts of Baghdad, in 2003 and 2004 was a "physical safe haven" for SJGs. A physical safe haven, according to the US Department of State's description is an ungoverned area "in which terrorist groups, because of inadequate governance capacity and security force, could freely organize, plan, raise funds, communicate, recruit, train, transit, and operate." 953 The definition was applicable to Iraq's Sunni Triangle. All three elements of Iraqbased SJGs, international jihadis, domestic Islamists, and the ex-Baathists grouped, regrouped, interacted and cooperated freely in ungoverned spaces of this area including Falluja, Ramadi, Samarra, Balad, Mosul and Tal Afar. In addition to Iraqi forces' inability to control these areas, the development and reorganization of SJGs in the Sunni Triangle were supported by tribes that mainly for sectarian reasons considered the Sunni insurgency as a defensive and resistance force. According to some tribal leaders who consistently met with the Coalition commanders, part of the tribes that supported the insurgency were people who were 'harmed' [by Americans and Shiites]. In an interview with PBS on November 30, 2003, Sheikh Gazi al-Essawi the leader of the Bu-Essa tribe in Falluja described the situation as, "the section of the society that was harmed, Baathists

\footnotetext{
${ }^{952}$ Eisenstadt and White, "Assessing Iraq's Sunni Arab Insurgency," 15; Greg Miller and Tyler Marshall, "More Iraqis Joining Zarqawi's Cause," Graham, “Zarqawi 'Hijacked' Insurgency; Eisenstadt and White, “Assessing Iraq's Sunni Arab Insurgency," 15-16. Los Angeles Times, September 15, 2005, p1; Graham, "Zarqawi 'Hijacked' Insurgency; Eisenstadt and White, “Assessing Iraq’s Sunni Arab Insurgency," 15-16.

${ }^{953}$ In its Country Reports on Terrorism, the U.S. Department of State describes terrorist safe havens as ungoverned, under-governed, or ill-governed physical areas where terrorists are able to organize, plan, raise funds, communicate, recruit, train, transit, and operate in relative security because of inadequate governance capacity, political will, or both. See "Chapter 5: Terrorist Safe Havens," in Country Reports on Terrorism 2015, U.S. Department of State, June 2016 (https://www.state.gov/j/ct/rls/crt/2015/257522.htm).
} 
that are harmed, yes, they probably have sympathy towards them [the insurgents]." Al-Essawi claimed that even the tribal leaders who met with the Coalition commanders receive death threats from their own tribesmen:

"Every week we meet with the [coalition] commander, as sheikhs and religious leaders, and I am one of them. Every week we meet with him. We are looked at as collaborators. Some say, 'You go and meet with the Americans. What did you achieve?' We did get death threats." 954

The insurgent alliance with the tribes in the Sunni Triangle was intense. The alliance between "Ansar al-Sunnah Army" and the "Army of Muslims," two al-Qaeda-linked armed factions, with Al-Janabi and al-Jbour, the biggest and most loyal tribes to Saddam Hussein, in Latifiyah is an example of the tribal-insurgency interactions. ${ }^{955}$ Tribal Sheikhs described Latifiyah as "a Taliban republic." 956

The Coalition's earlier focus on the Triangle met with a short-term success pushing Zarqawi and some main insurgent leaders to reposition on the border between Iraq and Syria. ${ }^{957}$ But jihadi cells and networks were too complex and multilayered to be eradicated by a foreign force. Despite the Coalition's selective operations in ungoverned areas, lack of an effective domestic force and intelligence developed into a permanent condition under which insurgent elements and networks could move freely, position and reposition frequently in different parts of the Sunni Triangle. For example, the insurgents were removed from the city of Fallujah through a

\footnotetext{
954 Sheikh Gazi al-Essawi, interview with PBS, November 30, 2003

(http:/www.pbs.org/wgbh/pages/frontline/shows/beyond/interviews/gazi.html).

${ }_{955}$ Muhammad Abdullah, "A Tribal Story from the Triangle of Death,” Naqash, July 7, 2008

(http://www.niqash.org/en/articles/politics/2241/).

${ }^{956}$ Abdullah, "A Tribal Story from the Triangle of Death."

${ }^{957}$ Mackubin T. Owens, "Sanctuary: The Geopolitics of Terrorism an Insurgency," in Jeffrey H. Norwitz (ed.), Pirates, Terrorists and Warlords: The History, Influence, and Future of Armed Groups Around the World (New York: Skyhorse Publishing, 2009), 151.
} 
joint Coalition and Iraqi operation, called Operation Panton Fury in November-December 2004. But due to a lack domestic forces, insurgent sanctuaries, cells, and networks quickly expanded within and around the city. The insurgent elements that had escaped the city continued to launch attacks on Fallujah and different towns around it until ISIS completely captured the city in early 2014. ${ }^{958}$

There are numerous examples of the IAF's both quantitative and qualitative weakness in the Sunni Triangle. Insurgent operations and attacks in the al-Anbar province, for instance, was the outcome of an insufficient number of security forces until mid-2007. There were only 200 unformed Iraqi police officers and provincial troops in Ramadi, the capital of the province, until July 2006, which were deployed to protect the city against thousands of insurgent and jihadi militants. ${ }^{959}$ When the number multiplied to 6,700 by mid-2007, insurgent attacks dropped correspondently. ${ }^{960}$ In addition to lack of sufficient numbers in specific areas, qualitative ineffectiveness was another problem. A remarkable instance, in this regard, is the fall of Fallujah and Mosul in 2014. In Mosul, for instance, an estimated 30,000 Iraqi soldiers could not defending the city and fled after a quick confrontation with as few as 800 militants belong to Baghdadi's ISI. ${ }^{961}$ An Iraqi policeman who was wounded in the battle described the IAF's defeat as "planes didn't come. Aid didn’t arrive. Support didn’t come to us. Nothing came." ${ }^{\prime 962}$ Even in areas under governmental control, the IAF was not capable of providing basic security. In a famous case, the governor of Al-Anbar Province, Abdul Karim Berges, resigned on August 5, 2004, following the

\footnotetext{
${ }_{958}$ Ahmad S. Hashim, Insurgency and Counterinsurgency in Iraq (Ithaca, New York: Cornell University Press, 2006), 40-46.

${ }^{959}$ Chris Caul, “A Ragtag Solution with Real Results," Los Angeles Times, May 7, 2007 (http://articles.latimes.com/2007/may/07/world/fg-kidcops7).

${ }^{960}$ Caul, "A Ragtag Solution with Real Results."

961 "Islamic State: What Has Happened Since the Fall of Mosul?" BBC, June 10, 2015 (http://www.bbc.com/news/world-middle-east-32784661).

962 Alice Fordham, "Iraq's Army is Ineffective Against Islamist Insurgents," NRP, June 13, 2014 (http://www.npr.org/2014/06/13/321544957/iraq-s-army-is-ineffective-against-islamist-insurgents).
} 
kidnapping of his three sons. In return for his sons' release, Barjas appeared on a videotape announcing his resignation and apologizing for resisting the insurgency:

"I am Abd al-Karim Barjas, governor of Al-Anbar. I declare before God and you my repentance of any action I did against the mujahedin, or any act in cooperation with the infidel, the Americans, and I announce my resignation from my post." 963

Thus, despite numerous joint Coalition and Iraqi forces' attacks and operations on against insurgency, the Sunni Triangle remained the heartland of SJGs in which all steps towards the formation of IS were taken. The development of JTJ into AQI in October 2004, for instance, took place in safe houses located in this area. Before to the emergence of AQI, Zarqawi was based in the Sunni Triangle and communicated with al-Qaeda cells and safe houses located mostly in tiny villages around Baghdad and other parts of the Triangle on the formation of AQI. ${ }^{964}$ All Sunni jihadis were based in the Sunni Triangle, mostly sheltering in villages and towns within the Sunni Triangle. ${ }^{965}$ Zarqawi was killed in Arab Shogah, a small village in Hibhib County, Dayala Governorate, 55 miles north of Baghdad. ${ }^{966}$

For early insurgent groups, cells were the dominant form of organization. Some cells were multifunctional carrying out attacks using different types of weapons, others were specialized, and involved in preparing forged documents or propaganda materials, or in planning and executing attacks with mortars, rockets, or vehicle-borne improvised explosive devices. ${ }^{967}$ Insurgent cells

\footnotetext{
963 "Fierce Fighting Escalates in Iraq," Radio Free Europe, August 6, 2004 (http://www.rferl.org/a/1054202.html).

${ }^{964}$ See Dexter Filkins, Mark Mazzitti, and Richard A. Oppel Jr., "How Surveillance and Betrayal Led to a Hunt's End," New York Times, June 9, 2006 (http://www.nytimes.com/2006/06/09/world/middleeast/09raid.html).

${ }_{965}$ Hawramany , "The Sunni Triangle of Death and Terror;" Michal R. Gordon and Damien Cave, "Military Strikes Insurgents' Base East of Baghdad," New York Times, June 19, 2007 (http://www.nytimes.com/2007/06/19/world/middleeast/19iraq.html).

966 John F. Burns, “U.S. Strike Hits Insurgent at Safehouse,” New York Times, June 8, 2008 (http://www.nytimes.com/2006/06/08/world/middleeast/08cnd-iraq.html).

967 James Janega, "Obscure Figures Hunted in Iraq," Chicago Tribune, April 20, 2005 (http://articles.chicagotribune.com/2005-04-20/news/0504200155 1 insurgent-cell-iraqi-soldier-suspects); For the description of IED cells see Greg Grant, "Inside Iraqi Insurgent Cells," Defense News, August 1, 2005
} 
and networks of cells were concentrated in neighborhoods, villages, and towns located in the Sunni Triangle which was home to large numbers of the former military regime and security personnel who had lost their jobs through the de-Baathification policy and, therefore, were intended to support the Sunni insurgency. ${ }^{968}$ This allowed different insurgent groups to gather and interact quickly. ${ }^{969}$ Quick interaction, strategy changes and communication facilities were significant conditions under which the scattered insurgency developed into a uniform organization with a single ideology and a common goal. The AQI's incorporation with five other Iraq-based insurgent groups in MSM as an umbrella organization in January 2006, and MSM's transformation into ISI in October 2006 took place under such conditions. ${ }^{970}$

Prior to the formation of ISI as a centralized organization, the Iraq-based insurgency was made up of a "web of networks" linked by personal, tribal, and group ties. ${ }^{971}$ Each group was believed to be involved in a range of activities, including recruitment, training, financing, propaganda, political activities, and guerrilla and terrorist attacks, while former regime elements mostly involved in a supporting role. ${ }^{972}$ Ex-Baathists, in particular, supplied SJGs with arms and ammunition they had access to. ${ }^{973}$ The former Iraqi Army's trained and experienced soldiers supported the SJGs with their intelligence and military skills which greatly increased the SJGs' effectiveness and organizational capacity ${ }^{974}$ As a result of the existence of these elements in the insurgency and the failure of the Coalition forces during and after the invasion to secure Iraqi

(https://www.myaoc.org/EWEB/images/aoc library/Events/2006/020806_EWIO_Awareness_Day/General_Informa tion/Inside Iraqi Insurgent Cell \%20DN 8-1-05.pdf); see also Montgomery McFate, "Iraq: The Social Context of IEDs," Military Review, May/June 2005: 37-40 (http://www.au.af.mil/au/awc/awcgate/milreview/mcfate3.pdf).

968 Eisenstadt and White, “Assessing Iraq's Sunni Arab Insurgency,"11.

969 Ibid., 5.

${ }^{970}$ Lister, "Profiling the Islamic State," 8; Those five groups included Jaish al-Taifa al-Mansurah; Katbiyan Ansar Al-Tawhid wal Sunnah, Saray al-Jihad Group, al-Ghuraba Brigades, and al-Ahwal Brigades.

${ }^{971}$ Eisenstadt and White, “Assessing Iraq's Sunni Arab Insurgency," 15.

972 Ibid.

973 Ibid., 5.

${ }^{974}$ Ibid. 
armories and ammunition storage points, insurgents in Iraq obtained a very large supply of arms, explosives, and munitions, probably more than they wanted or needed. ${ }^{975}$ Thus, lack of effective security forces, the extension of ungoverned areas in Iraq, the ex-Baathists' cooperation and incorporation with the insurgency, and the jihadi elements' access to weapons and intelligence, together, were significant conditions under which the early Iraqi insurgency developed into ISI.

The formation of the ISI marked a new phase of the war in Iraq. Now segmented insurgent groups were turned into a hierarchical and centralized jihadi organization with a fully structured cabinet, a sense-making Amir on its top, a defined doctrine, and a common goal. ${ }^{976}$ ISI combined all domestic and international elements of the Sunni insurgency in Iraq under a Salafi-Jihadi command which followed a Caliphate-based ideology. ${ }^{977}$ ISI developed into ISIS/ISIL by expanding its operations to Syria on April 9, 2013, and ultimately transformed into IS a year later when the Caliph announced the establishment of an Islamic State, after the group had captured Mosul. ${ }^{978}$ Accordingly, the one-decade-long process of the development of insurgency in Iraq, which was facilitated under the conditions provided by a weak state authority, resulted into the formation of a transnational jihadi organization which captured territory, operated beyond sovereign boundaries, created "mini-states" throughout the Muslim world, and extended terrorist cells in Western countries. The capture of Mosul on June 10, 2014 by ISIS was a turning point in the development of the terrorist organization into a self-declared "Islamic Caliphate." With its seizing of Mosul, ISIS not only took control of a major political and economic center with a

\footnotetext{
${ }^{975}$ Eisenstadt and White, "Assessing Iraq's Sunni Arab Insurgency," 10; Eric Schmitt and Lowell Bergman, "Security at Iraq Munitions Sites Is Vulnerable, U.S. Officials Say," New York Times, September 6, 2003 (http://www.nytimes.com/2003/09/06/world/struggle-for-iraq-munitions-security-iraq-munitions-sites-vulnerableus.html); Bradley Graham and Thomas Ricks, "Munitions Issue Dwarfs the Big Picture," Washington Post, October 29, 2004 (http://www.washingtonpost.com/wp-dyn/articles/A7418-2004Oct28.html).

${ }^{976}$ Lister, "Profiling the Islamic State," 8.

977 Ibid., 9.

${ }^{978}$ Ibid., 13.
} 
population of 1.8 million, but it also acquired US-made weaponry, including armored vehicles. ${ }^{979}$ Mosul became completely out of the control of the Iraqi government, with the Iraqi armed forces being unable to recapture it. Therefore, like all other predecessors of IS, from JTJ to AQI to ISI to ISIS, the establishment of IS took place under the condition provided by the lack of an effective and legitimate IAF and in a province completely out of the control of the Iraqi state. In Mosul, all jihadi and Baathist leaders declared allegiance to Abubakr al-Baghdadi as their caliph of the Islamic State. Both American and Iraqi officials admit that the slow process of forming a professional armed force in the post-Saddam Iraq was the main factor of insecurity which provided the conditions for the emergence of Iraq-based SJGs and their development into IS. According to Jack Keane, a retired American Army vice chief of staff and architect of the "surge" of 30,000 additional US troops into Iraq in 2007, "[the Americans] began to slowly put together a security force, but it took far too much time and that gave the insurgency an ability to start to rise." In an interview with the Time Magazine in May 2015, Keane described the Coalition's failure in reorganizing Iraq's army and police immediately after the occupation as "a huge strategic mistake." 980

\section{Lack of Capacity}

As discussed in the introduction, lack of state capacity was not a significant factor in the formation of IS. However, poverty and unemployment in Sunni communities magnified the impact of other major conditions (i.e., lack of legitimacy and poor authority), if it did not directly function as a third condition. The country's overall economic situation became worse with the collapse of service-providing institutions. An opinion poll conducted in March 2005 indicates that some 44

\footnotetext{
979 "Islamic State: What Has Happened Since the Fall of Mosul?"

980 Thompson, "How Disbanding the Iraqi Army Fueled ISIS."
} 
percent of respondents in the largely Sunni Arab Tikrit/Baquba area believed that infrastructure and economy was the most urgent issue facing the country. ${ }^{981}$ Both the Iraqi government and the Coalition were incapable of restoring the state institutions that had traditionally provided basic services to the Iraqi citizens. ${ }^{982}$ As a result, living conditions, particularly in the Sunni Triangle, dramatically worsened following the US invasion. ${ }^{983}$

Having removed thousands of Iraqis from the public sector, the Coalition was unable to provide adequate job opportunities. While millions were dismissed from their positions, the Coalition was only able to create some 30,000 jobs by July $2004 .{ }^{984}$ As a result, unemployment, particularly in Sunni areas, increased. Unemployment in Fallujah, for instance, was close to 60 percent in $2004 .{ }^{985}$ One of the reasons the city became a center of Iraqi insurgency as early as in mid-2003 was that the people thought their jobs were taken and they were betrayed by the political process in Baghdad. ${ }^{986}$ Those who had lost jobs and were not trusted to be rehired and the tribes that had lost state aid had no choice but to join the insurgency as an alternative source of employment where they could get well-paid salaries for attacking foreigners and Shiites. One source claims that one could receive up to $\$ 100$ for planting a roadside bomb or shooting an American soldier in $2004 .{ }^{987}$ In the same year, another source reports that insurgent leaders in Sunni areas "offered cash bounties of $\$ 1,000$ for a Shiite, $\$ 2,000$ for a member of the Iraqi National Guard and \$3,000 for an American." ${ }^{988}$ Another report from Latifiyah, in late 2004, shows that

\footnotetext{
${ }^{981}$ Eisenstadt and White, “Assessing Iraq's Sunni Arab Insurgency," 14.

${ }^{982}$ Cordesman, Iraq's Insurgency and the Road to Civil Conflict, 88.

${ }^{983}$ UN Assistance Mission for Iraq, Humanitarian Briefing on the Crisis in Iraq, May 2, 2007 (http://www.refworld.org/docid/488d96332.html).

${ }_{984}$ Frederick Barton and Bathsheba Crocker, "Progress or Peril: Measuring Iraq’s Reconstruction," CSIS, September 2004: 50.

${ }^{985}$ Cordesman, Iraq's Insurgency and the Road to Civil Conflict, 95.

${ }^{986}$ Ibid.

${ }^{987}$ Barton and Crocker, "Progress or Peril: Measuring Iraq's Reconstruction," 50.

${ }^{988}$ Associated Press, "Tringle of Death, South of Baghdad."
} 
insurgents "offered bounties of $\$ 1,000$ for a policeman, $\$ 2,000$ for a member of the National Guard, \$10,000 for an Iraqi journalist or translator and even more for a foreigner." 989 According to ISIS fighters, who were captured by the Kurdish forces in November 2016, payment was one the reasons they joined ISIS. Walid Ismail, a former bakery worker, and one of those captured by the Kurdish Peshmerga, stressed that financial pressure and threats leveled at him were the major factors in him signing up to wage jihad. According to the former baker, he was struggling to "support six younger siblings when ISIS cut off the gas supply to the bakery that employed him," therefore, he had no choice, but to join ISIS: "Daesh gave me 500,000 dinars (£340) per month to hold a machine gun and stand guard on a street." 990 Thus, increasing unemployment and poverty on the one hand, and the insurgency's ability to present an image of wealth and good payment, on the other, motivated a number of Sunni Arabs to look at it as an alternative employment source. Joining the insurgency for cash created what was primarily called "freelancers" who first joined the group for money and after became a staff member. ${ }^{991}$ Thus, the insurgency's payment capability fueled its recruitment engine, even if it was not a major factor in the development of insurgency into a uniform jihadi organization.

\footnotetext{
989 Shadid, "Iraq's Forbidding 'Triangle of Death.",

${ }^{990}$ Barnes, "Captured ISIS Fighters Reveal Secrete and Brutal Recruitment Tactics.”

${ }^{991}$ Grant, "Inside Iraqi Insurgent Cells."
} 


\section{Conclusion}

This dissertation engages in a three-decade-long debate on the relationship between state fragility and the rise of terrorist groups and examines the empirical findings through the lens of IR, international security, and development theories. By focussing exclusively on whether state fragility is a cause of terrorism or not, scholars have failed to examine the broader impact of state fragility on the formation and expansion of terrorist groups. A broad review of the literature on the state fragility-terrorism nexus, conducted in this research, indicates that the role of state fragility as a condition of the emergence of SJGs is ignored in the literature. This dissertation, adding state fragility as a condition variable to the causal framework of the emergence of SJGs, fills this gap. The dissertation, specifically, examines multiple aspects of state fragility in Afghanistan and Iraq as necessary conditions of the emergence of al-Qaeda and Islamic State (IS). This dissertation finds:

1. Al-Qaeda and IS are the outcome of a series of direct causes on all three levels of analysis

2. The impact of causal determinants on the formation of al-Qaeda and IS is conditioned with specific aspects of state fragility in Afghanistan and Iraq, respectively

3. While al-Qaeda and IS emerged in two highly fragile states, state fragility is not a direct cause of the formation of those organizations

4. Causal determinants at the three levels of analysis and state fragility conditions, together, were necessary factors of the emergence of the two cases

This research shows that al-Qaeda was the product of a series of direct causes such as the Afghan Arabs' search for personal security and their 'quest for significance' at the individual level, the Salafi-Jihadi ideology at the group level, and the United States' unipolar policies in the aftermath of the Cold War in Muslim regions and their consequences at the international level of analysis. 
However, the research finds that the formation of al-Qaeda was conditioned by state fragility in Afghanistan during the Taliban's Islamic Emirate of Afghanistan (IEA) in the mid-1990s. AlQaeda's formation benefited from all three aspects of state fragility in Afghanistan including lack of legitimacy, poor authority and lack of capacity. Concerning legitimacy, lack of a broad-based internal acceptance and international recognition had a significant impact on the formation of alQaeda. The IEA did not broadly represent citizens of Afghanistan and it was not officially recognized as a sovereign authority in Afghanistan by the international community. Therefore, the IEA lacked both representativeness and accountability. It did not represent the people it ruled and it was not accountable to both its citizens and the international community concerning activities that took place in areas it controlled. Lack of accountability, in particular, highly favored the formation of al-Qaeda. In addition, the IEA's reliance on Islamism as a source of legitimation was a significant condition leading to the emergence of al-Qaeda in Afghanistan. Islamism was a shared ideology to both the Taliban and bin Laden. Therefore, the IEA considered itself obliged, religiously, to provide hospitality and a safe haven for bin Laden and his international militants. Poor state authority was another condition that made the formation and expansion of al-Qaeda in Afghanistan possible. The IEA lacked a sufficient military and security force to end the war militarily and secure Afghanistan's territory and borders. Therefore the Arab jihadis infiltrated into the country unchecked and assembled primarily in ungoverned spaces of eastern and southern Afghanistan without facing any serious obstacle. Moreover, the Taliban relied on Arab military support and manpower and, therefore, it lacked the power to intervene in bin Laden's Affairs. Lack of authority and the Taliban's reliance on bin Laden's military support, in this sense, provided a condition under which bin Laden established al-Qaeda camps mostly unchecked. Finally, the IEA did not have a sufficient capacity both in terms of economic size and capability for acquiring the 
means of governance. In other words, the IEA neither had a sufficient economic size to manage state affairs regularly nor did it have the administrative capacity for extracting the means of producing official revenue to cover the costs. Therefore, the IEA heavily depended on foreign funds, particularly from bin Laden. The IEA's financial reliance, together with its military dependence, on Arabs was a favorable condition for bin Laden to operationalize his idea of alQaeda in Afghanistan without facing any problems. Furthermore, since the IEA did not have an expert administration to manage its economic affairs and the costs of war properly, economyrelated issues and, therefore, the management of war was supervised mainly by Arabs and Pakistanis. This also gave the Arabs jihadis a leverage in Afghanistan to operate freely. Taken together, the IEA's lack of legitimacy, authority and capacity created a condition under which alQaeda camps mushroomed and transformed into a uniform organization that would operate globally.

Like al-Qaeda, the formation of IS was the outcome of a series of causes at all three levels of analysis and magnified by state fragility in post-Saddam Iraq. In particular, two state fragility measures, lack of legitimacy and poor authority, in post-Saddam Iraq were the main conditions magnifying the impact of causal determinants on the formation of IS. Unlike the case of al-Qaeda, capacity played a only a small role in the case of IS. With respect to the root causes of the formation of IS, individual jihadis' search for personal security, the Iraqi Sunnis' experience of discrimination, and the international jihadis' quest for significance by confronting directly the sole great power in Iraq were the main determinants of the formation of IS at the individual level of analysis. Salafi-jihadism was the main cause at the group level. And the US invasions of Afghanistan and Iraq and their domestic and regional consequences were the root causes the rise 
of IS at the international level of analysis. The relationship between these determinants and the emergence of IS was magnified by lack of legitimacy and poor authority in post-Saddam Iraq.

In terms of legitimacy, lack of a broad-based government, discrimination against Sunnis, and the external intervention in Iraq developed into an environment in which individually motivated jihadis and insurgents organized themselves under a uniform jihadi organization that ultimately developed into IS. Following the collapse of Saddam's Baathist regime, post-Saddam state-building was mainly dominated by Shiites and Kurds, in which the traditional ruling group, the Sunnis, was marginalized. Therefore, Sunnis did not consider the political development of Iraq and its outcome in the 2000s legitimate. The post-Saddam political development led to a legitimacy gap which the Sunni insurgency was ready to fill. Moreover, both domestic and regional politics factored into a Shiite vs. Sunni confrontation in Iraq which was further fueled by the regional powers' intervention in Iraqi affairs. Lack of legitimacy, in this sense, provided the insurgency with a condition in which they were considered as a resistant movement. Under these circumstances, insurgent groups could easily recruit from Sunni communities, hide in Sunni areas, group, re-group and move easily in the Sunni Triangle with the support they received from local people. This condition not only facilitated the emergence and expansion of insurgency but also its development into a uniform organization that claimed to represent the Islamic State. In addition to lack of legitimacy, poor authority in the post-Saddam Iraq was another determinant condition of the formation of IS. Following the defeat of Saddam's regime, all essential components of state power, including its army, police, and intelligence disintegrated faster than it was predicted by the Americans. In contrast, the formation of a new army and security force by the Coalition was gravely slow in the face of a fast emerging insurgency. The disintegration of Iraq's armed forces and the slow process of its restoration resulted in the creation of ungoverned areas and borders. 
Under these circumstances, jihadi militants achieved the ability to move easily, making crossborder contacts and grouping in ungoverned areas in Baghdad and beyond. Without Iraqi forces being able to take on security tasks, coalition forces were compelled to police Iraq in ways that were unpleasant to the Iraqi public. The lack of a sufficient domestic force and the coalition's direct operations developed a condition of fear and chaos in the country, in which the seeds of the Iraq-based insurgency and its development into IS was planted. Taken together, the lack of sufficient security and military forces, political and managerial gaps in rebuilding Iraq's armed forces, and finally the Coalition's lack of relevant response to the security problems, widened the security vacuum in post-Saddam Iraq which a group such as IS was prepared to fill. The following table provides a comparative image of aspects of state fragility in Afghanistan (in 1990s) and Iraq (in 2000s) and their degree of effect on the emergence of al-Qaeda and IS.

\begin{tabular}{|l|l|l|l|}
\hline SGls & Lack of Legitimacy & Lack of Authority & Lack of Capacity \\
\hline Al-Qaeda & High Effect & High Effect & High Effect \\
\hline Islamic State & High Effect & High Effect & Marginal Effect \\
\hline
\end{tabular}

Although the empirical basis of this dissertation includes two case studies, the analytical framework developed in this research can be used for studying more similar cases. Although the two typical case studies of this research exemplify the relationship between state fragility and the emergence of SJGs I do not claim they represent the universe of cases. Therefore, "the puzzle of interest" of this research lays within the selected cases, rather than in cross-case levels for generalization purposes. Thus, the empirical findings of this dissertation are limited to the two case studies and are not generalizable. Therefore, this dissertation neither builds a theory nor claims the 
generalizability of the preliminary findings. Rather, it seeks to investigate the relationship between state fragility and the emergence of SJGs in two specific cases with the purpose of opening up the "black box of causality" for making a stronger within-case inference instead of a simplistic hypothesis testing. Generating a general theory, in this regard, requires the findings of this dissertation to be tested through a large-N research or intensive empirical research of a larger number of cases. More concretely, generating a general theory on the state fragility-SJGs nexus requires the findings of this research to be followed by more case studies - at least, the examination of other cases such as the emergence of al-Shabab in Somalia, Boko Haram in Nigeria, AQAP in Yemen and the like. Moreover, separate research on 'state-sponsored terrorism' such as the emergence of extremist groups in Pakistan would add further insight on the state fragility-terrorism nexus. Such research would reveal the complexity of the emergence of SJGs by addressing the possibility of interconnection between state fragility and state interest concerning the rise and expansion of global terrorism.

This dissertation makes a significant contribution to both academic debate and policy. In the academic area, this research adds new theory and evidence to the debate on the emergence of SJGs and international security. This research generates, for the first time, an analytical framework in which state fragility is considered as a condition variable in the model of the rise of SJGs. Moreover, the conceptualization of SJGs and their distinction from other types of Islamist and terrorist groups in this dissertation provides a clearer image of what is labeled as global terrorism and terrorist organizations. In policy, this dissertation makes a number of suggestions concerning international security, development and their interconnection. It suggests that investment in enhancing statehood in potential host countries to a JSGs is as effective as addressing the root causes of the emergence of such groups. Addressing the root causes of a JSG would help to deal 
with it effectively, while enhancing the degree of legitimacy, authority, and capacity in a fragile state as a potential host of a JSG would help to prevent the formation of such an organization, in the first place. This dissertation, therefore, invites further debate on the intersectionality between security and development and suggests the need to examine empirical findings concerning the rise of JSGs through the lens of the two literature. Such a debate would bring security and development studies together in studying the complex phenomenon known as "global terrorism." 


\section{Bibliography}

Abdo, Geneive. The New Sectarianism: The Arab Uprising and the Rebirth of the Shi 'a-Sunni Divide. Washington D.C.: The Brookings Institute, April 10, 2013.

Abdul Qudus, Sayed. The Pathans. Karachi: Oxford University Press, 1958.

Abdullah, Muhammad. "A Tribal Story from the Triangle of Death.” Naqash, July 7, 2008. Retrieved from (http://www.niqash.org/en/articles/politics/2241/).

Aabha, Dixit. "Soldiers of Islam: Origins, Ideology and Strategy of the Taliban." The Pioneer, June 11, 1997.

Abouzeid, Rania. "The Jihad Next Door: The Syrian Roots of Iraq's Newest Civil War." Politico, June 23, 2014. Retrieved from (http://www.politico.com/magazine/story/2014/06/al-qaeda-iraq-syria-108214).

Ahrari, Ehsan. "Saudi Arabia and Iran in Iraq Fix." Asia Times, December 20, 2006. Retrieved from (https://www.worldsecuritynetwork.com/Broader-Middle-East-Iran-UnitedStates/ehsan-ahrari/Saudi-Arabia-and-Iran-in-Iraq-fix).

AK Parti. "By-Law of the Justice and Development Party: With Amendments Effected in 2012." Retrieved from (https://www.akparti.org.tr/english/akparti/parti-tuzugu).

Alawi, Ali. The Occupation of Iraq: Winning the War, Losing the Peace. New Haven, CT: Yale University Press, 2007.

Al-Adnani, Abu Mohammad. "ISIS Spokesman Declares Caliphate, Rebrands Group as 'Islamic State.” SITE Intelligence Group. Retrieved from https://news.siteintelgroup.com/JihadistNews/isis-spokesmandeclares-caliphate-rebrands-group-as-islamic-state.html

Alexander, Yonah and Dean Alexander. The Islamic State: Combating the Caliphate Without Borders. Lanham: Lexington Books, 2015.

Al-Hashimi, Tariq and Anne L. Garrels. "A Conversation with Tariq al-Hashimi." Council on Foreign Relations, December 19, 2006. Retrieved from (http://www.cfr.org/iraq/tariq-alhashimi/p34170).

Aljazeera. “ISIL Wins Support from Iraq's Sunni Tribes.” June 4, 2015. Retrieved from (http://www.aljazeera.com/news/2015/06/sunni-sheiks-pledge-allegiance-isil-iraq-anbar150604074642668.html).

Al-Mukhtar, Othman. "Iraq's Borders Fall Out of Government's Control." Al-Arabia, April 8, 2015. Retrieved from (https://www.alaraby.co.uk/english/politics/2015/4/8/iraqs-bordersfall-out-of-government-control).

Al-Tamimi, Raad Sami., and Kevin E. Grisham, "Elections as a Tool for Political Participation in Iraq." International Journal of Contemporary Iraqi Studies 7(3), 2013: 233-249.

Al-Zawahiri, Ayman. His Own Words: Translation and Analysis of the Writings of Dr. Ayman al Zawahiri. Translation and Analysis by Laura Mansfield. Old Tappan, NJ: TLG, 2001a.

Al-Zawahiri, Ayman. "Knights Under the Prophet's Banner." In G. Kepel, \& J-P. Milelli. Eds. Al-Qaeda in Its Own Words. Translated by P. Ghazaleh, pp. 191-206. Cambridge, MA: Harvard University Press, 2001b.

Amnesty International. Afghanistan: Unfair Trails by Special Tribunals. London: Amnesty International, 1991: 5-6.

Amnesty International. “Amnesty International Report 2015/16: The State of the World's Human Rights.” 2016. Retrieved from (https://www.amnesty.org/download/Documents/POL1025522016ENGLISH.PDF).

Anderson, Liam and Gareth Stansfield. The Future of Iraq: Dictatorship, Democracy, or 
Division? (New York: Palgrave, 2004).

Arango, Tim and Eric Schmitt. "Escaped Inmates from Iraq Fuel Syrian Insurgency." The New York Times, February 12, 2014. Retrieved from (http://www.nytimes.com/2014/02/13/world/middleeast/escaped-inmates-from-iraq-fuelsyria-insurgency.html? $\mathrm{r}=0$ ).

Arvanitis, Kristina. "Lessons from Iraq: Electoral Legitimacy in the Shadow of Ethnoreligious Conflict." Templet Int' and Comp. L. J. 20(2), 2006: 529-559.

Arraf, Jane. "U.S. Dissolves Iraqi Army, Defense and Information Ministries,." $C N N$, May 23, 2003. Retrieved from (http://www.cnn.com/2003/WORLD/meast/05/23/sprj.nitop.army.dissolve/).

Asghar, Raja. "Pakistan Urges World to Recognize Afghan Taliban." Reuters, August 15, 1998.

Avalos, Hector. Fighting Words: Origins of Religious Violence. New York: Prometheus Books, 2005.

Associated Press. "Triangle of Death, South of Baghdad." November 19, 2004. Retrieved from (http://www.nbcnews.com/id/6530940/ns/world news-mideast n africa/t/triangle-deathsouth-baghdad/\#.WIFO3PkrJnI).

Atran, Scott. "Genesis of Suicide Terrorism." Science Magazine 299 (March, 2003): 1534-1539.

Azeez, Hawzhin. "Reconstructing Iraq: Iraq StateBuilding, Nation Building, and Violence." Nebula 7(4), 2010: 77-87.

Aziz, Shaista "Saudi Fighters 'Join Resistance' in Iraq." Al-Jazeera, October 28, 2003. Retrieved from (http://www.aljazeera.com/archive/2003/10/2008410141418821563.html).

Bakhash, Shaul. Reign of Ayatollahs: Iran and the Islamic Revolution. New York: Basic Books, 1984.

Baram, Amatzia. Culture, History and Ideology in the Formation of Ba'thi Iraq (London: MacMillan, 1991).

Baram, Amatzia. Who Are the Insurgents? Sunni Arab Rebels in Iraq. Washington D.C.: United States Institute of Peace, Special Report No. 134, April 2005.

Barnes, Joe. "Captured ISIS Fighters Reveal Secrete and Brutal Recruitment Tactics." Express, November 30, 2016. Retrieved from (http://www.express.co.uk/news/world/738231/isisfighters-reveal-terror-group-recruitment-tactics-iraq-syria).

Barfield, Thomas J. Afghanistan: A Cultural and Political History. New Jersey: Princeton University Press, 2010.

Barton, Frederick and Bathsheba Crocker. "Progress or Peril: Measuring Iraq's Reconstruction." Washington D.C.: Center for Strategic and International Studies, September 2004.

Blatter, Joachim \& Markus Haverland. Designing Case Studies: Explanatory Approaches in Small-N Research. New York: Palgrave, 2012.

Bayart, Jean F. The State in Africa: the Politics of the Belly. London: Longman, 1993.

BBC. "Profile: Moqtada al-Sadr." January 19, 2012. Retrieved from (http://www.bbc.com/news/world-middle-east-12135160).

BBC. "Islamic State: What Has Happened Since the Fall of Mosul?" June 10, 2015. Retrieved from (http://www.bbc.com/news/world-middle-east-32784661).

Beach, Derek \& Rasmus Brun Pedersen. Process Tracing Methods: Foundations and Guidelines. Ann Arbor, MI: The University of Michigan Press 2013.

Beehner, Lionel. "Iraq: Militia Groups." Council of Foreign Relations, June 9, 2005. Retrieved from (http://www.cfr.org/iraq/iraq-militia-groups/p8175).

Belen Soage, Ana. "Introduction to Political Islam." Religion Compass 3(5), 2009: 887-896. 
Ben-Dor, Gabriel and Ami Pedahzur. "The Uniqueness of Islamic Fundamentalism and the Fourth Wave of International Terrorism." Politics, Religion and Ideology 4(3), Sep. 2003: 71-90.

Bender, Bryan. "Study Cites Seeds of Terror in Iraq: War Radicalized Most, Probes Find." The Boston Globe, July 17, 2005. Retrieved from (http://irishantiwar.org/archives/news/101496.html).

Benjamin, Dan. The Age of Sacred Terror: Radical Islam. Maryland: Random House, 2003.

Bennett, Andrew. "Case Study Method: Design, Use and Comparative Advantages." in Models, Numbers, Cases: Methods of Studying International Relations, edited by Detlef F. Sprinz and Yael Wolinsky, 19-55. USA: University of Michigan Press, 2004.

Bergen, Peter L. The Longest War: The Enduring Conflict Between America and Al-Qaeda. New York: Free Press, 2011.

Berko, Anat and Edna Eriz. "Ordinary People and Death Work: Palestinian Suicide Bombers and As Victimizers and Victims." Violence and Victims 20(6), Dec. 2003: 603-623.

Berkowitz, Leonard. Aggression: A Social Psychological Analysis. New York: McGrawHill, 1962.

Berman Bruce J. "Ethnicity, Patronage and the African State: The Politics of Uncivil Nationalism." African Affairs 97(388), Jul. 1998: 305-341.

Bhatia, Michael. "Armed Groups in Afghanistan." in Afghanistan, Arms and Conflict: Armed Groups, Disarmament and Security in a Post-War Society, edited by Michael Bhatia and Mark Sedra, 72-110. New York: Routledge, 2008.

Bin Laden, Shaykh Osama bin-Muhammad. "Declaration of War against the Americans Occupying the Land of the Two Holy Places." Bin Laden's Fatwa, PBS NEWSHOUR, August 23, 1996. Retrieved from (http://www.pbs.org/newshour/updates/military-julydec96-fatwa 1996/).

Bin Laden, Shaykh Osama bin-Muhammad, et al. "World Islamic Front Statement: Jihad Against Jews and Crusaders." Federation of American Scientists, August 23, 1998. Retrieved from (http://fas.org/irp/world/para/docs/980223-fatwa.htm).

Bilgan. Pinar, and Adam David Morton. "Historicising Representations of 'Failed States': Beyond the Cold-War Annexation of the Social Sciences?" Third World Quarterly 23(1), 2002: 55-80.

Bjorgo, Tore. Root Causes of Terrorism: Myth, Reality and Ways of Forward. London and New York: Routledge, 2005.

Bjorgo, Tore and John Horgan, Leaving Terrorism Behind: individual and Collective Disengagement. New York: Routledge, 2008.

Boot, Max. "We Can't Afford to Let ISIS Run Wild in Iraq." The Spectator August 16, 2014. Retrieved from (https://www.spectator.co.uk/2014/08/defeat-isis-yes-we-can/).

Blanchard, Christopher M. Al-Qaeda: Statements and Evolving Ideology. CRS Report for Congress. 2007. Retrieved from (https://fas.org/sgp/crs/terror/RL32759.pdf).

Bloom, Mia. "Dying to Kill: Motivations for Suicide Terrorism." In Root Causes of Suicide Terrorism: The Globalization of Martyrdom, edited by Ami Pedahzur, 25-53. New York: Routledge, 2006.

Boase, Roger. Islam and Global Dialogue: Religious Pluralism and the Pursuit of Peace. Farnham \& Burlington: Ashgate, 2010.

Boghani, Priyanka. "In Their Own Words: Sunnis on Their Treatments In Maliki’s Iraq.” PBS, 
October 28, 2014. Retrieved from (http://www.pbs.org/wgbh/frontline/article/in-theirown-words-sunnis-on-their-treatment-in-malikis-iraq/).

Borum, Randy, "Understanding Terrorist Psychology." Mental Health Law \& Policy Faculty Publications. Paper 576, 2010. Retrieved from (http://scholarcommons.usf.edu/mhlp facpub/576).

Bouillon, Markus E. "Iraq's State-Building Enterprise: State Fragility, State Failure and a New Social Contract." International Journal of Contemporary Iraqi Studies 6(3), 2012: 281-297.

Brinkerhoff, Derick W., Anna Wetterberg and Stephen Dunn, "Service Delivery and Legitimacy in Fragile and Conflict-Affected States: Evidence from Water Services in Iraq," Public Management Review 14(2), 2012: 273-293.

Brooks, Risa A. "Muslim Homegrown Terrorism in the United States: How Serious is the Threat?" International Security 36(2), 2011: 7-47.

Brooks, Rosa E. "Failed States, or State as Failure," The University of Chicago Law Review 72/4 (2005): 1159-1196.

Bueno de Mesquita, Bruce. The War Trap. New Haven: Yale University Press, 1981.

Burke, J. Al-Qaeda: The true story of radical Islam. London, New York, NY: I.B. Tauris, 2006.

Bulac, Ali. “On Islamism: Its Roots, Development, and Future," Insight Turkey 14(4), 2012: 67-85.

Bunzel, Cole. "From Paper State to Caliphate: the Ideology of the Islamic State." The Brookings Institute, Analysis Paper No. 19. March 2015.

Burns, John. "Islamic Rule Weighs Heavily for Afghans." The New York Times. September 24, 1997: A6.

Burns, John. "U.S. Strike Hits Insurgent at Safehouse.” New York Times, June 8, 2008. Retrieved from (http://www.nytimes.com/2006/06/08/world/middleeast/08cnd-iraq.html).

Call, Charles T. "Beyond the 'Failed State': Toward Conceptual Alternatives," European Journal of International Relations 17(2), 2010: 303-326.

Carment, David. “Assessing State Failure: Implications for Theory and Policy," Third World Quarterly 24(30), 2003: 407-427.

Carment, David, Stewart Prest, and Yiagadeesen Samy. Security, Development, and the Fragile State: Bridging the Gap between Theory and Policy. London: Routledge 2010.

Castillo, Graciana del. Rebuilding War-Torn States: The Challenge of Post-Conflict Economic Reconstruction. Oxford University Press, 2008.

Caul, Chris. "A Ragtag Solution with Real Results." Los Angeles Times, May 7, 2007. Retrieved from (http://articles.latimes.com/2007/may/07/world/fg-kidcops7).

CBS News. "Interview with General John Abizaid, Commander of the U.S. General Command in Iraq." June 26, 2005. Retrieved from (http://www.cbsnews.com/htdocs/pdf/face 062605.pdf).

Chandler, David. Empire in Denial: The Politics of State-Building. London: Pluto Press, 2006.

Choucri, Nazli, and Robert North. Nations in Conflict. San Francisco: Freeman, 1975

Choueiri, Youssef M. Islamic Fundamentalism: The Story of Islamist Movements, $3^{\text {rd }}$ Edition. London: Continuum, 2010.

Chouvy, Pierre-Arnaud. Opium: uncovering the politics of the poppy. Cambridge, Massachusetts: Harvard University Press, 2010.

CIA Special Collections. "The Cost of Soviet Involvement in Afghanistan." Released as 
Sanitized in 2000. Accessed December 5, 2015. Retrieved from

http://www.foia.cia.gov/sites/default/files/document conversions/89801/DOC 00004993 20.pdf

Clemons, Steve. "Thank God for the Saudis': ISIS, Iraq and the Lessons of Blowback." The Atlantic, June 23, 2014. Retrieved from

(https://www.theatlantic.com/international/archive/2014/06/isis-saudi-arabia-iraq-syriabandar/373181/).

Cockburn, Patrick. The Rise of Islamic State: ISIS and the New Sunni Revolution. London and New York: Verso, 2014.

Coggins, Bridget L. "Does State Failure Cause Terrorism? An Empirical Analysis (19992008)." Journal of Conflict Resolution 59(3), 2015: 455-483.

Cohen, Ronald, and Judith D. Toland, eds. "State Formation and Political Legitimacy." Political Anthropology 6. New Bronswik and Oxford: Transaction Books, 1988.

Collier, David. 1993. The comparative method. In A.W. Finifter (Ed.), Political science: The state of the discipline II 105-119. Washington, D.C: American Political Science Association, 1993.

Collier, David \& James Mahoney. "Insights and pitfalls: Selection Bias in Qualitative Research," World Politics 49(1), 1996: 56-91.

Collier, Paul. "The Political Economy of State Failure." Oxford Review of Economic Policy 25(2), 2009: 219-240.

Collins, Stephen D. "State Sponsored Terrorism: In Decline, Yet Still a Potent Threat." Politics \& Policy 42(1), 2014: 131-1569.

Cooper, Barry. New Political Religions or an Analysis of Modern Terrorism. Columbia: University of Missouri Press, 2004.

Corbin, Jane. Al-Qaeda: In Search of the Terror Network that Threatens the World. New York: Thunder's Mouth Press, 2002.

Crone, Manni \& Martin Harrow. 'Homegrown Terrorism in the West." Terrorism and Political Violence, 23(4), 2011: pp. 521-536.

Could, Elizabeth and Paul Fitzgerald. Crossing Zero: The Afpak War At The Turning Point of American Empire. New York: Open Media Series | City Lights Books, 201.

Crone, Mani and Martin Harrow. "Homegrown Terrorism in the West." Terrorism and Political Violence 23(4), 2011: 521-536.

Cronin, Andrey K. "Sources of Contemporary Terrorism." In Attacking Terrorism: Elements of a Grand Strategy, edited by Andrew K. Cronin and James M. Ludes, 19-45. Washington D.C., George Town University Press, 2004.

Davidson, Lawrence. Islamic Fundamentalism: An Introduction. Connecticut: Greenwood Press, 2003.

Davies, James. “Toward a Theory of Revolution." American Sociological Review 6(1), Feb. 1962: 5-19.

Dawisha, Adeed. Iraq: A Political History From Independence to Occupation (Princeton and Oxford: Princeton University Press, 2009).

Dawisha, Adeed and Larry Diamond. "Iraq's Year of Voting Dangerously." Journal of Democracy 17(2), 2006: 89-103.

De Graaff, Bob. "The Impossibility of a Global Counter Terrorism Strategy, or the End of the Nation-State." In Critical Perspectives on Counterterrorism, edited by Lee Jarvis and Michael Lister. New York and London: Routledge, 2015. 
Deikman, Arthur J. "The Psychological Power of Charismatic Leaders in Cults and Terrorist Oragizations." in The Making of a Terrorist: Recruiting, Training and Root Causes, edited by James J. F. Forest, vol. 2, Westport, Connecticut, London: Praeger Security International, 2006: 71-84.

Dekmejian, Richard. H. Islam in Revolution: Fundamentalism in the Arab World. Second Edition. New York: Syracuse University Press, 1995.

Del Castillo, Graciana. Rebuilding War-Torn States: The Challenge of Post-Conflict Economic Reconstruction. Oxford University Press, 2008.

Dobbins, James, Seth G. Jones, Benjamin Runkle, Siddharth Mohandas, Occupying Iraq: The History of the Coalition Provisional Authority. Santa Monica, Arlington, Pittsburgh: RAND, 2009.

Dodge, Toby. "Iraqi Transitions: From Regime Change to State Collapse." Third World Quarterly, 26(4/5), 2005: 705-721.

Dolard, John., Doob, L., \& Miller, N. E. Frustration and Aggression. New Haven: Yale University Press, 1939

Dressler, Jeffrey A. The Haqqani Network: From Pakistan to Afghanistan. Washington DC: Institute for the Study of War, 2010.

Dugas, M \& A. W. Kruglanski, A. W. The Quest for Significance Model of Radicalization: Implications for the Management of Terrorist Detainees, Behavioral Sciences and the Law, 32, (2014), 423-439.

Dupree, Louis. Afghanistan. Princeton: Oxford University Press, 1973.

Eckstein, H. Case studies and theory in political science. In F. I. Greenstein \& N. W. Polsby (Eds.), Handbook of political science. Political science: Scope and theory 7, 1975: 94137.

Eisenstadt, Michael. "Sitting on Bayonets: America's Postwar Challenges in Iraq." The National Interest. Summer 2004. Retrieved from (http://nationalinterest.org/article/sitting-onbayonets-americas-postwar-challenges-in-iraq-468).

Eisenstadt, Michael., and Jeffery White, Assessing Iraq's Sunni Arab Insurgency. Washington D.C.: The Washington Institute for Near East Policy, December 2005

Esposito, John L. The Islamic Treat: Myth or Reality. Third Edition. New York: Oxford University Press, 1999.

Esposito, John L. Unholy War: Terror in The Name of Islam. New York: Oxford University Press, 2002.

Esposito, John L. "Terrorism and the Rise of Political Islam." In The Roots of Terrorism, edited by Louise Richardson, 143-158. New York and London: Routledge, 2006.

Eubank, W. and L. Weinberg. Terrorism and Democracy: Perpetrators and Victims." Terrorism and Political Violence 13(1), 2001: 155-164.

Ewans, Martin. Afghanistan: A New History. Second Edition. London and New York: Routledge, 2002.

Fair, C. Christine. Fighting to the End: The Pakistan Army's Way of War. New York: Oxford University Press, 2014.

Faisal, Irshad. "Isis, Isil, IS, or Daesh? One group, many names." BBC Monitoring, December 2, 2015. Retrieved from (http://www.bbc.com/news/world-middle-east-27994277).

Falk, Richard, Mark Juergensmeyer, and Vesselin Popovsky, ed. Legality and Legitimacy in Global Affairs. New York: Oxford University Press, 2012.

Farah, Tawfic. Pan-Arabism and Arab Nationalism: The Continuing Debate. Boulder: Westview 
Press, 1987.

Felter, Joseph and Brian Fishman. "Al-Qaeda's Foreign Fighters in Iraq: A First Look at the Sinjar Records." Combating Terrorism Center at West Point, January 5, 2008. Retrieved from (http://www.ctc.usma.edu/wp-content/uploads/2010/06/aqs-foreign-fighters-iniraq.pdf).

Filkins, Dexter., Mark Mazzitti, and Richard A. Oppel Jr. "How Surveillance and Betrayal Led to a Hunt's End." New York Times, June 9, 2006. Retrieved from (http://www.nytimes.com/2006/06/09/world/middleeast/09raid.html).

Finish Immigration Service. "Security Situation in Baghdad-The Shia Militias," Finnish Immigration Service." April 29, 2015. Retrieved from (http://www.migri.fi/download/61225 Security Situation in Baghdad The Shia Militias 29.4.2015.pdf?ad032df6eb3dd488).

Fisher, Max. "How the Iranian-Saudi Proxy Struggle Tore Apart the Middle East." New York Times, November 19, 2016. Retrieved from (http://www.nytimes.com/2016/11/20/world/middleeast/iran-saudi-proxy-war.html).

Fishlock, Trevor. "Fire of the Taliban Threatens to Ignite Oil Region." Electronic Telegraph, Issue 1178, August 16, 1998.

Flibbert, Andrew. "The Consequences of Forced State Failure in Iraq." Political Science Quarterly 28(1), Spring 2013: 67-95.

Fordham, Alice. "Iraq's Army is Ineffective Against Islamist Insurgents." NRP, June 13, 2014. Retrieved from (http:/www.npr.org/2014/06/13/321544957/iraq-s-army-is-ineffectiveagainst-islamist-insurgents).

Forest. James J. F. Ed. The Making of a Terrorist: Recruiting, Training and Root Causes. 3 vols. Westport, Connecticut, London: Praeger Security International, 2006. Fromkin, David. A Peace to End All Peace: Creating the Modern Middle East, 1914-1922

(Harmondsworth: Penguin, 1991).

From [Excised] to DIA Washington D.C. [Excised], Cable "[Excised]/Pakistan Interservice Intelligence/ Pakistan (PK) Directorate Supplying the Taliban Forces." Secret, National Security Archive at George Washington University, October 22, 1996 http://nsarchive2.gwu.edu//NSAEBB/NSAEBB227/15.pdf

From [Excised] to DIA Washington D.C. "IIR [Excised] Pakistan Involvement in Afghanistan," Confidential, National Security Archive at George Washington University, November 7, 1996.

Fry, Maxwell J. “A Monetary Approach to Afghanistan's Flexible Exchange Rate.” Journal of Money, Credit and Banking, 8(2), 1976, 219-225.

Fukuyama, Francis. "The Soviet Union and Iraq Since 1968." A Rand Note Prepared for the United States Air Force. N-1524-AF July 1980. Accessed December 5, 2015. https://www.rand.org/content/dam/rand/pubs/notes/2007/N1524.pdf

Fukuyama, Francis. State-Building: Governance and World Order in the $21^{\text {st }}$ Century. Ithaca and New York: Central University Press, 2004.

Galbraith, Peter. The End of Iraq: How Americans Incompetence Created a War Without End? New York: Simon \&Schuster, 2006.

Gambhir, Harleen. "ISIS Global Intelligence Summery." Institute for the Study of War, March 1May 72015.

Gambhir, Harleen. "ISIS Declares Governorate in Russia's North Caucasus Region.” Institute for the Study of War, June 23, 2015.

Gambhir, Harleen. "ISIS's Global Strategy: A Wargame." The Institute for Study of War. Middle East Security Report 28, July 2015. 
Gambill, Gary. “Abu Musab al-Zarqawi: A Biographical Sketch.” Jamestown Terrorism Monitor 2(24), December 15, 2004. Retrieved from

(http://www.jamestown.org/single/?no cache $=1 \&$ tx ttnews[tt_news] $=27304$ ).

Geddes, Barbara. "How the Cases You Choose Affect the Answers You Get: Selection Bias in Comparative Politics." Political Analysis 2, 1990: 131-150.

George, Alexander L. 'Case Study and Theory Development: The Method of Structured Focused Comparison.' In Diplomacy: New Approaches in History, Theory and Policy. (Ed.), Paul G. Lauren, pp. 43-68. New York: The Free Press, 1979.

George, Alexander and Andrew Bennett. Case Study and Theory Development in the Social Sciences. Cambridge: MIT Press, 2005.

George Donabed, Sargon. Reforging a Forgotten: Iraq and the Assyrians in the Twentieth Century (Edinburg: Edinburg University Press, 2015).

George, Susanah. "Breaking Badr." Foreign Policy, November 6, 2014. Retrieved from (http://foreignpolicy.com/2014/11/06/breaking-badr/).

Gelfand, Lauren. "Al-Qaeda in Iraq Regroups and Names New Leadership." Jane's Defense Weekly 47(21), May 19, 2010.

Gerges, Fawaz A. The Far Enemy: Why Jihad Went Global. New York: Cambridge University Press, 2005.

Gerges, Fawaz A. The Rise and Fall of Al-Qaeda. New York: Oxford University Press, 2011.

Gerges, Fawaz A. ISIS: A History. Princeton: Princeton University Press, 2016.

Gerring, John. "Is There a (Viable) Crucial Case Method?" Comparative Political Studies 40(3), 2007: 231-253.

Gerring, John \& Cojocaru, Lee. "Selecting Cases for Intensive Analysis: A Diversity of Goals and Methods." Social Methods and Research 45(3), 2016: 392-423.

Ghosh, Bobby. "ISIS: A Short History." The Atlantic, August 14, 2014. Retrieved from (http://www.theatlantic.com/international/archive/2014/08/isis-a-short-history/376030/).

Gilley, Bruce. The Right to Rule: How States Win and Lose Legitimacy (New York: Columbia University Press, 2009).

Giustozzi, Antonio. War, Politics, and Society in Afghanistan, 1978-1992. Washington DC: Georgetown University Press, 2000.

Giustozzi, Antonio. Empires of Mud: War and Warlords in Afghanistan. London: Hurst \& Company, 2009.

Goodson, Larry P. Afghanistan's Endless Wars: State Failure, Regional Politics, and the Rise of the Taliban. Seattle and London: University of Washington Press: 2001.

Gordon, Michal R. and Damien Cave. "Military Strikes Insurgents' Base East of Baghdad." New York Times, June 19, 2007. Retrieved from (http://www.nytimes.com/2007/06/19/world/middleeast/19iraq.html).

Government of U.K. "Country Information and Guidance Iraq: Sunni (Arab) Muslims." August 2016: 23-33. Retrieved from (https://www.gov.uk/government/uploads/system/uploads/attachment_data/file/565850/C IG-Iraq-Sunnis-v1-August-2016.pdf).

Graham, Bradley. "Zarqawi 'Hijacked' Insurgency: U.S. General Says Foreign Fighters Now Seen as Main Threat." Washington Post, September 28, 2005. Retrieved from (http://www.washingtonpost.com/wpdyn/content/article/2005/09/27/AR2005092701601.html). 
Graham, Bradley and Thomas Ricks. "Munitions Issue Dwarfs the Big Picture.” Washington Post, October 29, 2004. Retrieved from (http://www.washingtonpost.com/wpdyn/articles/A7418-2004Oct28.html).

Grant, Greg. "Inside Iraqi Insurgent Cells." Defense News, August 1, 2005. Retrieved from (https://www.myaoc.org/EWEB/images/aoc library/Events/2006/020806 EWIO Aware ness_Day/General_Information/Inside_Iraqi_Insurgent_Cell \%20DN_8-1-05.pdf).

Green, Daniel R. "A New Strategy to Defeat al-Qaeda in Yemen." Foreign Policy Research Institute, 2014: 521-539 https://www.fpri.org/article/2014/10/a-new-strategy-to-defeat-alqaeda-in-yemen/

Gregorian, Vartan. The Emergence of Modern Afghanistan. Stanford: Stanford University Press, 1969.

Gschwend, Thomas \& Frank Schimmelfennig (eds.). Research Design in Political Science: How to Practice What They Preach. New York: Palgrave, 2007.

Gunaratna, Rohan. Inside al-Qaeda: Global Network of Terror. New York: Colombia University Press, 2002.

Gunaratna, Rohan and Arabinda Acharya. "The Terrorist Training Camps of al-Qaeda." in The Making of a Terrorist: Recruiting, Training and Root Causes, edited by James J. F. Forest vol. 2, Westport, Connecticut, London: Praeger Security International, 2006: 172193.

Gurr, Ted Robert. Why Men Rebel. Princeton, N.J.: Princeton University Press, 1970.

Hagan, John., Joshua Kaiser, Anna Hanson, Patricia Parker, "Neighborhood Sectarian Displacement and the Battle for Baghdad: A Self-Fulfilling Prophecy of Fear and Crimes against Humanity in Iraq." Sociological Forum 30(3), 2015: 675-697.

Haken, Nate, et al. Fragile States Index 2014. Washington D. C. The Fund For Peace Publication, 2014. Retriever from (http://ffp.statesindex.org/indicators).

Hall, Peter A. "Political Science and the New Three Institutionalisms." Political Studies 44(5), 1996: 936-957.

Hawramany, Nazhad Khasraw. "The Sunni Triangle of Death and Terror." New York Times, September 23, 2004. Retrieved from (http://www.freerepublic.com/focus/fnews/1224093/posts).

Harvey, Derek and Michael Pregent, "Who's to Blame for Iraq Crisis?” CNN, June 12, 2014. Retrieved from (http://edition.cnn.com/2014/06/12/opinion/pregent-harvey-northern-iraqcollapse $/$ ? $\mathrm{c}=$ \&page $=0$ ).

Hashim, Ahmad S. Insurgency and Counterinsurgency in Iraq. Ithaca, New York: Cornell University Press, 2006.

Hassin, Ahmad. "The Failure of Neo-Liberal State-Building in Iraq: Assessing Australia's PostConflict Reconstruction and Development Initiatives." Australian Journal of Politics and History 62(1), 2016: 87-99.

Heggharmmer, Thomas. Jihad in Saudi Arabia: Violence and Pan-Islamism since 1979. Cambridge: Cambridge University Press, 2010.

Hehir, Aida. "The Myth of the Failed State and the War on Terror: A Challenge to the Conventional Wisdom." Journal of Intervention and Statebuilding 1(3), 2007: 307-332.

Hellmich, Christina. "Creating the Ideology of al-Qaeda: from Hypocrites to Salafi-Jihadists." Studies in Conflict \& Terrorism 31, 2008: 111-124.

Henderson, Simon. "The Battle for Iraq is a Saudi War on Iran.” Foreign Policy, June 12, 2014. 
Retrieved from (http://foreignpolicy.com/2014/06/12/the-battle-for-iraq-is-a-saudi-waron-iran/).

Henzel, Christopher. "The Origins of the Al Qaeda Ideology: Implications for U.S. Strategy." Parameters, Spring, 2005: 69-80.

Herring, Eric and Glen Rangwala, Iraq in Fragments: The Occupation and Its Legacy Ithaca, New York: Cornell University Press: 2006.

Higel, Lahib. "Iraq's Displacement Crisis: Security and Protection," Minority Rights Group International, March 2016. Retrieved from (http://minorityrights.org/publications/iraqsdisplacement-crisis-security-and-protection/).

Hinsley, F. H. "The Concept of Sovereignty and the Relations Between States." Journal of International Affairs Vol. 21, No. 2 (1967), pp. 242-252

Hoffman, Bruce. Inside Terrorism. New York: Colombia University Press 2006.

Hoffman, Bruce. Insurgency and Counter Insurgency in Iraq. Santa Monica, Arlington, Pittsburgh: RAND, June 2004.

Hoffmann, Bruce and Gordon H. McCormick. "Terrorism, Signaling and Suicide Attacks," Studies in Conflict and Terrorism 27(4), 2004: 243-281.

Hogg, M. H., \& S A Reid. "Social Identity, Self-Categorization, and the Communication of Group Norms." Communication Theory 16, 2006: 7-30.

Homer-Dixon, Thomas F. "On the Threshold: Environmental Change as Causes of Acute Conflict." International Security 16(2), Fall 1991: 76-116.

Horgan, John. The Psychology of Terrorism. London and New York: Routledge, 2005.

Horgan, John. "Understanding Terrorist Motivation: A Socio-Psychological Perspective." In Maping Terrorism Research: State of the Art, gaps and future direction, edited by Magnus Ranstorp, 106-126. London and New York: Routledge, 2007.

Horgan, John. "Individual Disengagement: A Psychological Analysis." In Leaving Terrorism Behind: individual and Collective Disengagement, edited by Tore Bjorgo and John Horgan, 17-29. New York: Routledge 2008.

Horgan, John and Kurt Braddock. "Rehabilitating the Terrorists? Challenges in Assisting the Effectiveness of De-radicalization Programs." Terrorism and Political Violence 22(2), 2010: 267-291.

Huband, Mark. "Saudis in Iraq 'Preparing for a Holy War.'” Financial Times, August 18, 2003. Retrieved from (http://www.informationclearinghouse.info/article4477.htm).

Human Rights Watch. "Iraq: Possible War Crimes by Shia Militia." January 31, 2016. Retrieved from (https://www.hrw.org/news/2016/01/31/iraq-possible-war-crimes-shia-militia).

Ibrahimi, S. Yaqub. "Theory of the Rise of al-Qaeda." Behavioral Sciences of Terrorism and Political Aggression. 2017.

Ignatieff, Michael. Blood and Belonging. Toronto: Viking Press, 1993.

Ignatius, David. "How ISIS Spread in the Middle East: And How to Stop It." The Atlantic, October 29, 2015. Retrieved from (http://www.theatlantic.com/international/archive/2015/10/how-isis-started-syriairaq/412042/).

International Republican Institute. Survey of Iraqi Public Opinion. September 6 to September 12, 2005. Retrieved from http://www.iri.org/sites/default/files/2005-09-27Iraq\%20poll\%20Sept $\% 20$ Sept.pdf.

Iqbal, Anwar. U.S Senate Warns Against Disengagement From Afghanistan. DAWN, updated 
October 28, 2014. Accessed February 16, 2016. Retrieved from (http://www.dawn.com/news/1140861).

Jackson, Jeffrey W. Military Intervention in Identity Group Conflicts: A Social Movement Theory Perspective on the Sunni Insurgency in Iraq. Monterey: Naval Postgraduate School, 2006.

Jackson, Robert. From Anarchy to Cosmopolis: Classical and Modern Thought on International Relations. New York: Palgrave Macmillan, 2005.

Jackson, Robert. "Surrogate Sovereignty? Great Power Responsibility and 'Failed States.", Institute of International Relations, the University of British Colombia. Working Paper No. 25. 1998.

Jackson, Robert and Alan James. States in a Changing World: A Contemporary Analysis. New York: Oxford University Press, 1993.

Jalata, A. Phases of Terrorism in Age of Globalization: From Christopher Columbus to Osama Bin Laden. New York, NY: Palgrave Macmillan, 2016.

Janega, James. "Obscure Figures Hunted in Iraq." Chicago Tribune, April 20, 2005. Retrieved from (http://articles.chicagotribune.com/2005-04-20/news/0504200155 1 insurgent-celliraqi-soldier-suspects).

Jarvis, Lee and Michael Lister, eds., Critical Perspectives on Counterterrorism. New York and London: Routledge, 2015.

Jasser, M. Zuhdi, et al. Muslim Reform Movement. Gatestone Institute, December 6, 2015. Accessed December 29, 2015. Retrieved from (http://www.gatestoneinstitute.org/7009/muslim-reform-movement).

Jenkins, Brian. Would-Be Warriors: Incidents of Jihadist Terrorist Radicalization in the United States Since September 11 2001. Santa Monica, CA: RAND Corporation, 2010.

Johnson, Thomas and Chris Mason. "Democracy in Afghanistan is Wishful Thinking." Christian Science Monitor. August 20, 2009

Jones. Seth G. "The Rise of Afghanistan's Insurgency: State Failure and Jihad." International Security 32(4), spring 2008: 7-40.

Juergensmeyer, Mark, "Religion as a Cause of Terrorism." In The Roots of Terrorism. Edited by L. Richardson, 133-144. New York and London: Routledge, 2006.

Juergensmeyer, Mark. "The Legitimacy of Invading Religious Regimes," in Legality and Legitimacy in Global Affairs, edited by Richard Falk, Mark Juergensmeyer, and Vesselin Popovsky. New York: Oxford University Press, 2012.

Karam, Zeina and Qassim Abdul-Zahra. “Al Qaeda's Nusra Front Leader Stays in Syria Shadows." The National, November 4, 2013. Retrieved from (http://www.thenational.ae/world/middle-east/al-qaedas-nusra-front-leader-stays-insyrias-shadows).

Kaufmann, Daniel. Art Kraay, and Massimo Mastruzzi, The Worldwide Governance Indicators: Methodology and Analytical Issues. The World Bank. Draft Policy Research Working Paper. Retrieved from (http://info.worldbank.org/governance/wgi/pdf/wgi.pdf).

Keynoush, Banafsheh. Saudi Arabia and Iran: Friends or Foes? New York: Palgrave, 2016 Khalilzad, Zalmay and David Ochmanek. "Rethinking US Defence Planning." Survival 39(1), Spring 1997: 43-64.

Khan, L. Ali. A Theory of International Terrorism: Understanding Islamic Militancy. Boston: Martinus Nijhoff Publishers, 2006.

King, G., Rober Keohane \& Sidney Verba, Designing social inquiry: scientific inference in 
qualitative research. Princeton, NJ: Princeton University Press, 1994.

Kirdar, M. J. "Al-Qaeda in Iraq.” CSIS, Case Study Series: Case Study Number 1. June, 15, 2011. Retrieved from (http://csis.org/files/publication/110614_Kirdar_AlQaedaIraq_Web.pdf).

Kissinger, Henry. World Order. New York: Penguin Press HC, 2014.

Kittner, Cristina C. B. "The Role of Safe Havens in Islamist Terrorism." Terrorism and Political Violence 19, 2007: 307-329.

Knights, Michael. The Future of Iraq's Armed Forces. Baghdad: al-Bayan Center for Planning and Studies, 2016. Retrieved from (http://www.bayancenter.org/en/wpcontent/uploads/2016/03/The-future.pdf).

Koran, Tony. "Understanding Iraq's Ethnic and Religions Divide," Time Magazine, Feb. 24, 2006. Retrieved from (http://content.time.com/time/world/article/0,8599,1167476,00.html).

Krasner, Stephen D. Sovereignty: Organized Hypocrisy. New Jersey: Princeton University Press, 1999.

Krieger, Tim and Daniel Meierrieks. "What Causes Terrorism." Public Choice 147 (2011): 3-27.

Krohley, Nicholas. "Moqtada al-Sadr's Difficult Relationship with Iran." Hurst, August 7, 2014. Retrieved from (http://www.hurstpublishers.com/moqtada-al-sadrs-difficult-relationshipwith-iran/).

Kruglanski A. W. and S. Fishman, "The Psychology of Terrorism: 'Syndrome' Versus 'Tool' Perspectives." Terrorism and Political Violence 18(2), 2006: 193 - 215.

Kruglanski, A. W., \& E. Orehek, "The Role of the Quest for Personal Significance in Motivating Terrorism." In J. Forgas, A. W. Kruglanski, \& K. Williams. Eds. The Psychology of Social Conflict and Aggression: 153-166. New York, NY: Psychology Press, 2011.

Lapidus, Ira M. "Islamic Revival and Modernity: The Contemporary Movements and the Historical Paradigms." Journal of the Economic and Social History of the Orient 40(4), 1997: 444-460.

Laub, Zachari. "Pakistan's New Generation of Terrorists." Council on Foreign Relations, November 18, 2013. Retrieved from (https://www.cfr.org/backgrounder/pakistans-newgeneration-terrorists).

Lester, David, and Bijou Yang, Mark Lindsay. "Suicide Bombers: Are Psychological Profiles Possible?" Studies in Conflict and Terrorism 27(4), 2004: 283-295.

Leuffen, Dirk. "Case Selection and Selection Bias in Small-n Research." In Thomas Gschwend \& Frank Schimmelfennig (eds.). Research Design in Political Science: How to Practice What They Preach (145-160). New York: Palgrave, 2007.

Lewis, Jessica D. "Al-Qaeda in Iraq Resurgent: The Breaking the Walls Campaign, Part I." Institute for the Study of War, September 2013, 15. Retrieved from (http://www.understandingwar.org/sites/default/files/AQI-Resurgent-10Sept_0.pdf).

Lijphart, Arend. 1971. Comparative politics and comparative method. American Political Science Review, 65, 682-693.

Lister, Charles. "Profiling the Islamic State." The Brookings Institute, Brookings Doha Center Analysis Papers No.13. November 2014.

Lister, Charles R. The Islamic State: A Brief Introduction. Washington D. C.: The Brookings Institute Press, 2015.

Lutz, James M. and Brenda J. Lutz. Terrorism: Origins and Evolution. New York: Palgrave, 2005. 
MacFarquhar, Neil "For Arabs, New Jihad is in Iraq." New York Times, April 2, 2003. Retrieved from (http://www.nytimes.com/2003/04/02/world/a-nation-at-war-the-islamic-world-forarabs-new-jihad-is-in-iraq.html;

Mackey, Sandra. The Reckoning: Iraq and the Legacy of Saddam Hussein. New York: W.W. Norton \& Company, 2002.

MacLeod, Scott. "The Saudi Push for an Iraq Coup.” Time Magazine, January 16, 2003. Retrieved from (http://content.time.com/time/world/article/0,8599,408784,00.html).

Maleckova, Jitka. "Impoverished Terrorism: Stereotype or reality?" In Root Causes of Terrorism: Myth, Reality and Ways Forward, edited by Tore Bjorgo, pp-pp. London: Routledge, 2005.

Maley, William. The Afghanistan Wars. $2^{\text {nd }}$ Edition. London: Palgrave Macmillan, 2009.

Malsin, Jared. "Why Some Arab States Refuse to Accept Syrian Refugees." Time Magazine, September 15, 2015. Accessed December 9, 2015. Retrieved from (http://time.com/4025187/arab-states-syrian-refugees/).

Mamdani, Mahmood. Good Muslim, Bad Muslim. New York: Pantheon Books, 2004.

Mantzikos, Ioannis. "Somalia and Yemen: The Links Between Terrorism and State Failure." Digest of Middle East Studies 20(2), 2011: 242-260.

Marshall, Monty G., \& Gabrielle Elzinga-Marshall. Global Report 2017: Conflict, Governance, and State Fragility. Vienna, VA: Center for Systemic Peace, 2017.

Marr, Phebe. The Modern History of Iraq. Boulder: Westview Press, 1989.

Mazarr, Michael J. "The Psychological Sources of Islamic Terrorism.” Policy Review 125, 2004: 39-60.

McFate, Montgomery. "Iraq: The Social Context of IEDs." Military Review, May/June 2005: 3740. Retrieved from (http://www.au.af.mil/au/awc/awcgate/milreview/mcfate3.pdf).

McGregor, Andrea. "Al Qaeda's Egyptian Prophet: Sayyid Qutb and the War on Jahiliya." Terrorism Monitor 1/3, October 10, 2003. Accessed 20 January 2016. Retrieved from (http://www.jamestown.org/programs/tm/single/?tx ttnews\%5Btt_news\%5D=18980\&tx ttnews\%5BbackPid\%5D=178\&no cache=1\#.VrzKn IrLDc).

Mellon, James J. "Pan-Arabism, Pan-Islamism, and Inter-State Relations in the Arab World." Nationalism and Ethnic Politics 8(4), 2002: 1-15.

Mesbahi, Mohiaddin. "The USSR and the Iran-Iraq War: From Brezhnev to Gorbachev," in The Iran-Iraq War: The Politics of Aggression, edited by Farhang Rajaee, 69-102. Florida: University Press of Florida, 1993.

Metcalf, Barbara D. Islamic Revival in British India: Deobandi, 1860-1900. Princeton: Princeton University Press, 1982.

Miller, Greg and Tyler Marshall. "More Iraqis Joining Zarqawi’s Cause.” Los Angeles Times, September 15, 2005.

Milliken, Jennifer and Keith Krause. "State Collapse, State Failure and State Reconstruction: Concepts, Lessons and Strategies," Development and Change 33(5), 2002: 753-74.

Moghaddam, Assaf. "Palestinian Suicide Terrorism in the Second Intifada: Motivations and Organizational Aspects." Studies in Conflict and Terrorism 26, 2003: 65-92.

Moghadam, Assaf. "The Roots of Suicide Terrorism: A Multi-Causal Approach.” In Root Causes of Suicide Terrorism: The Globalization of Martyrdom, edited by Ami Pedahzur, 81-107. London and New York: Routledge 2006.

Mohamedou, Mohammad-Mahmoud Ould, Understanding al-Qaeda: the Transformation of War. London: Pluto Press, 2007.

Momayezi, Nasser. "Islamic Revivalism and the Quest for Political Power." Journal of Conflict 
Studies 17(2), Fall 1997: 115-132.

Monteiro, Nuno. Theory of Unipolar Politics. New York: Cambridge University Press, 2014. Moore, John. "The Evolution of Islamic Terrorism: An Overview." PBS: Frontline. Accessed Retrieved from (http://www.pbs.org/wgbh/pages/frontline/shows/target/etc/modern.html).

Most Benjamin A. and Harvey Starr. Inquiry, Logic and International Politics. Columbia: University of South Carolina Press, 1989.

Murden, Simon W. Islam, the Middle East and the New Global Hegemony. London: Lynne Rienner Publishers, 2002.

Nance, Malcolm W. The Terrorists of Iraq: Inside the Strategy and Tactics of the Iraq Insurgency 2003-2014, Second Edition. Florida: CRC Press, 2015.

Napoleoni, Loretta. Insurgent Iraq: Al-Zarqawi and the New Generation. New York: Seven Stories Press, 2005.

Nasr, Sayyed Vali Reza. Islamic Leviathan: Islam and the Making of the State Power. New York, NY: Oxford University Press, 2001.

"National Commission on Terrorist Attacks Upon the United States. Staff Statement No. 15, June 16, 2004. Retrieved from (http://govinfo.library.unt.edu/911/staff_statements/staff_statement 15.pdf).

Negus, Steve. "Infiltrate Iraq the Easy Way: Pop Over the Syrian Border." Financial Times, September 27, 2004. Retrieved from (http://www.ft.com/cms/s/0/8b0989b6-1022-11d9ba62-00000e2511c8.html?ft site $=$ falcon\&desktop=true).

Nesser, Petter. 'Jihadism in Western Europe after the Invasion of Iraq: Tracing Motivational Influences from the Iraq War on Jihadist Terrorism in Western Europe.' Studies in Conflict \& Terrorism, 29(4), 2006: pp. 323-42.

Nesser, Petter. 'How Did Europe's Global Jihadis Obtain Training for Their Militant Causes?' Terrorism and Political Violence, 20(2), 2008: pp. 234-256.

Newell, Richard S. and Nancy P. Newell. The Struggle for Afghanistan. Ithaca, NY: Cornell University Press, 1981.

Newman, Edward. "Weak States, State Failure, and Terrorism," Terrorism and Political Violence, 19, 2007: 463-488.

Nojum, Neamatollah. The Rise of the Taliban in Afghanistan: Mass Mobilization, Civil War and the Future of the Region. New York: Palgrave, 2002.

Norton, Richard Augustus, ed. Civil Society in the Middle East, vols. 1 and 2. Leiden: E.J. Brill Publishers, 1994 \& 1995.

Nyrop, Richard F. and Donald M. Seekins, eds. Afghanistan: A Country Study. Washington, DC: Foreign Areas Study, American University, 1986.

Obaid, Nawaf and Anthony Cordesman. Saudi Militants in Iraq: Assessment and Kingdom's Response. Washington D.C.: Center for Strategic and International Studies, September 19, 2005.

O’Driscoll, Dylan. “Autonomy Impaired: Centralisation, Authoritarianism, and the Failing Iraqi State." Ethnopolitics, Sept., 2015, (1-18)

Ollivant, Douglas A. "Not an Iraqi Civil War." Middle East Political Science 36, 2013: (34-38). Retrieved from http://pomeps.org/wpcontent/uploads/2014/06/POMEPS_Studies4_Sectarianism.pdf

Otterman, Sharon. “Iraq: Iraq's Prewar Military Capabilities.” April 24, 2003. Retrieved from (http://www.cfr.org/iraq/iraq-iraqs-prewar-military-capabilities/p7695).

Owens, Mackubin T. "Sanctuary: The Geopolitics of Terrorism an Insurgency." in Jeffrey H. 
Norwitz (Ed.), Pirates, Terrorists and Warlords: The History, Influence, and Future of Armed Groups Around the World: 142-155. New York: Skyhorse Publishing, 2009.

Oxford Islamic Studies Online. "Islamic Modernism and Islamic Revival."

Retrieved from (http://www.oxfordislamicstudies.com/article/opr/t253/e9).

Pan, Esther. "Q\&A: Iraq: Sunnis, the Elections, and the Insurgency." The New York Times, December 23, 2005. Retrieved from (http://www.nytimes.com/cfr/international/slot3 122305.html?pagewanted=all).

Pape, Robert A. Dying to Win: The Strategic Logic of Suicide Terrorism. London: Random House, 2005.

Pape, Robert, A. 2006. "Suicide Terrorism and Democracy: What We've Learned Since 9/11," Policy Analysis No. 582

Palmer, Monte and Princess Palmer. Islamic Extremism: Causes, diversity and Challenges. Lanham: Rowman and Littelfield Publishers, Inc., 2008.

Parson, Anthony. From Cold War to Hot Peace: UN Interventions 1974-1994. London: Penguin Books Ltd, 1995.

Partlow, Joshua. "Iraqi Officials Say Insurgent Cell Bombed Shiite Shrine." Washington Post, June 29, 2006. Retrieved from (http://www.washingtonpost.com/wpdyn/content/article/2006/06/28/AR2006062802028.html).

Patrick, Stewart. Weak Links: Fragile States, Global Threats and International Security. New York: Oxford University Press, 2011.

PBS Frontline. "In Search of al-Qaeda." An Interview with Mary Anne Weaver, the Author of Pakistan: In the Shadow of Jihad and Afghanistan. Retrieved from (http://www.pbs.org/wgbh/pages/frontline/shows/search/etc/weaver.html).

Pedahzur, Ami, ed. Root Causes of Suicide Terrorism: The Globalization of Martyrdom. London and New York: Routledge 2006.

Peters, B. Guy. Strategies for Comparative Research in Political Science. New York: Palgrave, 2013.

Peterson, M. J. Recognition of Governments: Legal Doctrine and State Practice, 1815-1995. London: Macmillan, 1997.

Pfiffner, James, P. "US Blunders in Iraq: De-Baathification and Disbanding the Army," Intelligence and National Security 25(1), 2010: 76-85.

Piazza, J. A. "Draining the Swamp: Democracy Promotion, State Failure, and Terrorism in 19 Middle Eastern Countries.” Studies in Conflict, Terrorism 30(6), 2007: 521-539.

Piazza, J. A. "Incubators of Terror: Do Failed and Failing States Promote International Terrorism?" International Studies Quarterly 52(3), Sep. 2008: 469-488.

Porter, Tom. "ISIS: Five U.S. Mistakes Which Led to the Rise of Islamic State." International Business Times, June 11, 2015. Retrieved from (http://www.ibtimes.co.uk/isis-five-usmistakes-which-led-rise-islamic-state-1505642).

Post, Jerrold M. "The New Face of Terrorism: Socio-Cultural Foundations of Contemporary Terrorism." Behavioral Sciences and the Law 23, 2005: 451-465.

Post, Jerrold M. "The Psychological Dynamics of Terrorism." in The Roots of Terrorism, edited by Louise Richardosn, 17-28. New York and London: Routledge, 2006.

Post, Jerold, M. "When Hatred is Bred in the Bone: the Sociocultural Underpinnings of Terrorist Psychology." in The Making of a Terrorist: Recruiting, Training and Root Causes, edited by James J. F. Forest, vol. 2, Westport, Connecticut, London: Praeger Security International, 2006: 13-33. 
Post, Jerrold M. The Mind of the Terrorist: The Psychology of Terrorism from the IRA to AlQaeda. New York: Palgrave MacMillan, 2007.

Pravda, "No One Knows Why USSR Started War in Afghanistan." December 28, 2009.

Retrieved from (http://english.pravda.ru/history/28-12-2009/111437-ussr_afghanistan-0/).

Pressman, Jeremy. "Rethinking Transnational Counterterrorism: Beyond a National

Framework." The Washington Quarterly 30(4) autumn 2007: 63-73.

Queiroz, Regina. "Sovereignty, Global Justice and Terrorism." In Terrorism: Politics, Religion, Literature, edited by Diego Pires Aurelio and Joao Tiago Proenca, pp-pp. Newcastle: Cambridge Scholars Publishing, 2011.

Qutb, Sayyid. "The America I have Seen: In the Scale of Human Values." In America in an Arab Mirror: Images of America in Arabic Travel Literature, edited by Kamal Abdel-Malak, 9-28. New York: St. Martin's Press, 2000.

Rabasa, Angela. et al. Deradicalizing Islamic Extremism. California: Rand Corporation, 2010.

Radio Free Europe. "Fierce Fighting Escalates in Iraq.” August 6, 2004. Retrieved from (http://www.rferl.org/a/1054202.html).

Ragin, Charles C. The Comparative Method: Moving Beyond Qualitative and Quantitative Strategies. Oakland: University of California Press, 2014.

Rashid, Ahmad. "Scourge of God: Scourge of God: Strict Islamic Rules Imposed in Afghanistan by the Ruling Taliban are Plunging that Strife-Torn Country Deeper Into Ruin." Far Eastern Economic Review. August 7, 1997: 52.

Rashid, Ahmad. Taliban. Second Edition. New York: Yale University Press, 2001.

Rathmell, Andrew., Olga Oliker, Terrence K. Kelly, David Brannan, Keith Crane, Developing Iraq's Security Sector: The Coalition Provisional Authority's Experience. Santa Monica, Arlington, Pittsburgh: RAND, 2005.

Razwy, Sayed A. A. A Restatement of the History of Islam and Muslims. Stanmore: The World Federation of Muslim K.S.I. Communities, 1997.

Recknagel, Charles. "What Drives Sunni Anger in Iraq?" Radio Free Europe, June 23, 2014. Retrieved from (http://www.rferl.org/a/iraq-sunni-anger-causes/25432218.html).

Reid, Robert H. "Shiites, Kurds Emerge as Winners in Iraq." Associated Press, February 14, 2005 (http://forums.thesmartmarks.com/index.php?showtopic=67001).

Reidel, Bruce. "The Search for Al Qaeda: Its Leadership, Ideology, and Future.” The Brookings Institution, 2008.

Rice, Susan and Stewart Patrick. Index of State Weakness in the Developing World. New York: The Brookings Institute Press, 2008.

Richardson, Louise. (Ed.), The Roots of Terrorism. New York: Routledge, 2006.

Ricks, Thomas. Fiasco: The American Military Adventure in Iraq. New York: Penguin Press 2006.

Roggio, Bill. "Exodus and Ascent." The Long War Journal. March 30, 2005. Retrieved from (http://www.longwarjournal.org/archives/2005/03/exodus_and_asce.php).

Roshandel, Jalil and Sharon Chadha. Jihad and International Security. New York: Palgrave Macmillan, 2006.

Rosiny, Stephan. "The Rise and Demise of the IS Caliphate," Middle East Policy 22(2), summer 2015: 94-107.

Ross, Dennis B. "Islamists Are Not Our Friends," The New York Times, 11/09/2014.

Roth, John; Douglas Greenburg and Serena Wille. Al Qaeda's Means and Methods to Raise, 
Move, and Use Money. National Commission on Terrorist Attacks Upon the United States: Terrorist Financing Staff Monograph, 2004: 28. Retrieved from (http://govinfo.library.unt.edu/911/staff statements/911 TerrFin_Ch2.pdf).

Rotberg, Robert I., ed. State Failure and State Weakness in a Time of Terror. Washington D.C., The Brookings Institute Press, 2003.

Rotberg, Robert I. "The New Nature of Nation-State Failure.” Washington Quarterly 25(3), 2002: 85- 96.

Rothstein, Bo. "Creating Political Legitimacy: Electoral Democracy versus Quality of Government." American Behavioral Scientist 53(3), 2009: 311-330.

Roy, Olivier. "Al-Qaeda Brand Name Ready for Franchise: The Business of Terror." Le Monde Diplomatique, September 1, 2004. Accessed February 1, 2016.

Roy, Olivier. Islam and Resistance in Afghanistan $2^{\text {nd }}$ ed. Cambridge: Cambridge University Press, 1990.

Roy, Olivier. "The New Political Elite in Afghanistan," in The Politics of Social Transformation in Afghanistan, Iran and Pakistan, edited by Myron Weiner and Ali Banuaziz. New York: Syracuse University Press 1994: 72-100.

Roy, Olivier. "Terrorism as Deculturation.” In The Roots of Terrorism. Edited by L. Richardson, 159-171. New York and London: Routledge, 2006.

Rubin, Alissa J. "Ineffective Iraqi Force in Fallujah Disbanded.” Los Angeles Times, September 11, 2004. Retrieved from (http://articles.latimes.com/2004/sep/11/world/fg-fallouja11).

Rubin, Barnett R. The Fragmentation of Afghanistan. New Haven: Yale University Press, 2002.

Rubin, Barnett R. "The Fragmentation of Afghanistan," Foreign Affairs, 68(5), Winter 19891990: 150-168.

Rubin, Barry. "Pan-Arab Nationalism: The Ideological Dreams as Compelling Force," Journal of Contemporary History 26(3-4), 1991: 535-551.

Samuel, Gabriel. "Julian Assange: ISIS and Clinton Foundation are Both Funded by Saudi Arabia and Qatar." The Independent, November 4, 2016. Retrieved from (http://www.independent.co.uk/news/people/julian-assange-clinton-foundation-isis-samemoney-saudi-arabia-qatar-funding-a 7397211.html).

Saleh Ambah, Faiza. "Saudi Fighters Cross Border to Kill Infidels.” Washington Times, August 31, 2003. Retrieved from (http://www.washingtontimes.com/news/2003/aug/31/20030831-121933-2108r/).

Seawright, Jason \& Geering, John. Case selection technique in case study research: A menu of qualitative and quantitative options. Political Research Quarterly, 61(2), 2008: 294-308.

Sedgwick, Mark. "Al-Qaeda and the Nature of Religious Terrorism." Terrorism and Political Violence 16(4) 2004: 795-814.

Schmitt, Eric. "The Struggle for Iraq: Infiltration, U.S. Commanders Say Increased Border Patrols are Halting the Influx of Non-Iraqi Guerilla." New York Times, April 20, 2004. Retrieved from (http://www.nytimes.com/2004/04/20/world/struggle-for-iraq-infiltrationus-commanders-say-increased-border-patrols-are.html).

Schmitt, Eric and Lowell Bergman. "The Struggle for Iraq: Munitions; Security at Iraq Munitions Sites is Vulnerable, U.S. Officials Say." New York Times, September 6, 2003. Retrieved from (http://www.nytimes.com/2003/09/06/world/struggle-for-iraq-munitionssecurity-iraq-munitions-sites-vulnerable-us.html).

Schmitt, Eric and Lowell Bergman, "Security at Iraq Munitions Sites Is Vulnerable, U.S. 
Officials Say.” New York Times, September 6, 2003. Retrieved from (http://www.nytimes.com/2003/09/06/world/struggle-for-iraq-munitions-security-iraqmunitions-sites-vulnerable-us.html).

Sierakowska-Dyndo, Jolanta. "The State in Afghanistan's Political and Economic System on the Eve of the April 1978 Coup." Central Asian Survey 9(4), 1990: 85-97.

Simon, Steven and Ray Takeyh. "Iran's Iraq Strategy." The Washington Post, May 21, 2006.

Retrieved from (http://www.washingtonpost.com/wpdyn/content/article/2006/05/19/AR2006051901761. html).

Simons, Geoff. Iraq: From Sumer to Saddam (New York: St. Martins, 1994).

Singer, J. David. "The Level of Analysis Problem in International Relations." World Politics 14(1), Oct. 1961: 77-92.

Singh, Rashmi. Hamas and Suicide Terrorism: Multi-Causal and Multi-Level Approaches. London: Routledge, 2011.

Shadid, Anthony. "Iraq's Forbidding 'Triangle of Death.” Washington Post, November 23, 2004. Retrieved from (http://www.washingtonpost.com/wp-dyn/articles/A57102004Nov22.html).

Shadid, Anthony. "Iraq's Last Patriot," The New York Times Magazine, February 4, 2011 (http://www.nytimes.com/2011/02/06/magazine/06ALLAWI-t.html).

Sharnoff, Michael. “The Syria-Soviet Alliance.” inFocus Quarterly. Accessed December 5, 2015. Retrieved from (http://www.jewishpolicycenter.org/833/the-syria-soviet-alliance).

Shahrani, Nazif M. State Formation and Social Fragmentation in Afghanistan. In A. Banuazizi and M. Wiener (eds.), The State, Religion, and Ethnic Politics in Afghanistan, Iran, and Pakistan, 23-74. New York: Syracuse University Press 1986.

Shahrani, Nazif M. and Robert L. Canfield, eds. Revolutions and Rebellions in Afghanistan. Berkeley: University of California, Institute of International Studies, 1984.

Shay, Shaul. The Shahids: Islam and Suicide Attacks. New Jersey: Transaction Publishers, 2004. Sherif, M. Group Conflict and Cooperation: Their Social Psychology. London: Routledge, 1966.

Skaine, Rosemarie. Women of Afghanistan in the Post-Taliban Era: How Lives Have Changed and Where They Stand Today. Jefferson, North Carolina and London: McFarland \& Company, Inc, Publishers, 2008.

Sly, Liz. "The Hidden Hand Behind the Islamic State Militias? Saddam Hussein's." The Washington Post, April 04, 2015. Retrieved from (https://www.washingtonpost.com/world/middle east/the-hidden-hand-behind-theislamic-state-militants-saddam-husseins/2015/04/04/aa97676c-cc32-11e4-87304f473416e 759 story.html).

Smaldino, Paul E. "The Cultural Evolution of Emergent Group-Level Traits," Behavioral and Brian Sciences 35, 2014: 243-254.

Soage, Ana Belen. "Introduction to Political Islam." Religion Compass 3(5) (2009): 887-896.

Solomon, Erika. "Factbox: Syria's Rebel Groups." Reuters, January 9, 2014. Retrieved from (http://www.reuters.com/article/us-syria-crisis-rebels-factboxidUSBREA080SW20140109).

Spencer, Richard. "Syria: Jabhat al-Nusra Split After leader's Pledge of suppoart for al-Qaeda." The Telegraph, May 19, 2013.

Stansfield, Gareth. Iraq: People, History, and Politics (Malden: Polity Press, 2007).

Stenersen, Anne. "Al-Qaeda versus Najibullah: Revisiting the Role of Foreign Fighter in the 
Battle of Jalalabad and Khost, 1989-92." In War and State-Building in Afghanistan:

Historical and Modern Perspective, edited by Scott Gates and Kaushik Roy. London and New York: Bloomsbury, 2015: 131-146.

Swann, W. B., A. Gomez, J Dovidio, S. Hart, \& J Jetten, "Dying and Killing for One's Group: Identity Fusion Moderates Responses to Intergroup Versions of the Trolley Problem," Psychological Science, 21, 2010: 1176-1183.

Szajkowski, Bogdan (ed).1981. Documents in Communist Affairs 1980. London and Basingstoke: The Macmillan Press LTS.

Tajfel, Henri., ed. Differentiation between Social Groups. London: Academic Press, 1978.

Tajfel, Henri. Human Groups and Social Categories: Studies in Social Psychology. Cambridge: Cambridge University Press, 1981.

Takeuchi, Shinichi, Ryutaro Murotani, and Keiichi Tsunekawa. "Capacity Traps and Legitimacy Traps: Development Assistance and State Building in Fragile Situations." In Catalyzing Development: A New Vision for Aid, ed. H. Kharas, K. Makino and W. Jung, 127-154. Washington D.C: Brookings Institute Press, 2011.

Taylor, Andrew. State Failure. London: Palgrave Macmillan, 2013.

Taylor, Guy. "Refugee Crisis Sparks Debate on Role of Rich Gulf Countries." The Washington Times, September 23, 2015. Accessed December 9, 2015. Retrieved from (http://www.washingtontimes.com/news/2015/sep/23/syrian-refugees-being-shunned-bygulf-states/).

Thompson, Mark. "How Disbanding the Iraqi Army Fueled ISIS.” Time Magazine. May 28, 2015. Retrieved from (http://time.com/3900753/isis-iraq-syria-army-united-statesmilitary/).

Thourni, Francisco E. "The Rise Two Drug Tigers: The Development of Illegal Drug Industry and Drug Policy Failure in Afghanistan and Colombia, in The Organized Crime Community: Essays in Honor of Alan A. Block, edited by Frank Bovenkerk and Michael Levi, 125-148. New York: Springer, 2007.

Tibi, Bassam. The Challenge of Fundamentalism: Political Islam and he New World Order. New York: Routledge, 2008.

Tibi, Bassam, Islamism and Islam. New Haven and London: Yale University Press, 2012.

Tikuisis, Peter and Davis Carment. "Categorization of States beyond Strong and Weak." Stability: International Journal of Security and Development 6(1): 2017, 1-23.

Tilly, Charles. "War-Making and State-Making as Organized Crime." In Bringing the State Back, edited by Evans, P., D. Rueschemeyer, and T. Skocpol: 169-191. New York: Cambridge University Press, 1985.

Tilly, Charles. Coercion, Capital, and European States, AD 990-1990. Oxford and Cambridge: Blackwell Publishers, 1990.

Tikuisis, Peter. "On the Relationship between the Week States and Terrorism." Behavioral Science of Terrorism and Political Aggression 1(1), 2009: 66-79.

Tisdall, Simon. "WikiLeaks's Cables: Saudi Arabia Rated Bigger Threat to Iraq Stability than Iran." The Guardian, December 5, 2010. Retrieved from (https://www.theguardian.com/world/2010/dec/05/wikileaks-cables-saudi-meddlingiraq).

Tran, Mark. "Iraq's Biggest Sunni Block Quit Government," The Guardian, August 1, 2007. Retrieved from (https://www.theguardian.com/world/2007/aug/01/iraq.marktran).

Turner, John. "From Cottage Industry to International Organisation: The Evolution of Salafi- 
Jihadism and the Emergence of the Al Qaeda Ideology." Terrorism and Political Violence 22, 2010: 541-558.

U.N. Assistance Mission for Iraq. "Humanitarian Briefing on the Crisis in Iraq." May 2, 2007. Retrieved from (http://www.refworld.org/docid/488d96332.html).

U.N. General Assembly, Human Rights Council. "Joint Written Statement Submitted by the International Youth and Student Movement for the United Nations..." June 7, 2016. Retrieved from (http://www.ecoi.net/file upload/1930 1467890015 g1611379.pdf).

U.N. Security Council. "With the New Government, Iraq's Three-Year Political Transition Complete, Although Accompanied by Instability, Violence, Security Council Told." United Nations SC/8751, June 15, 2006. Retrieved from (https://www.un.org/press/en/2006/sc8751.doc.htm).

Underhill, Natasha. Countering Global Terrorism and Insurgency: Calculating the Risk of State Failure in Afghanistan, Pakistan, and Iraq. London: Palgrave 2014.

UNHCR-The UN Refugee Agency. “Total Number of Syrian Refugees Exceeds Four Million For First Time," July 5, 2015. Retrieved from (http://www.unhcr.org/559d67d46.html).

Usher, Sebastian. "Baathist Mistakes Corrected Amid Concern." BBC News, January 12, 2008. Retrieved from (http://news.bbc.co.uk/2/hi/middle east/7185276.stm).

Vincent, Juan. "Sovereignty, Legitimacy and Power: Prolegomena to the Study of the Colonial State in Early Modern Uganda." in State Formation and Political Legitimacy, edited by Ronald Cohen and Judith D. Toland. New Brunswick: Transaction Books, 1988: 137154.

Van Evera, Stephen. Guide to Methods for Students of Political Science. London: Cornell University Press, 1997.

Von Hippel, Karin. “'The Roots of Terrorism: Probing the Myths.' The Political Quarterly 73(1), 2002: 25-39.

Wallach, Janet. The Dessert Queen: The Extraordinary Life of Gertrude Bell (New York: Doubleday, 1995).

Waltz, Kenneth N. Man, the State and War: A Theoretical Analysis. New York: Colombia University Press, 1954.

Waltz, Kenneth N. Theory of International Politics. Boston: McGrawhill, 1979.

Weatherford, Stephen. "Measuring Political Legitimacy." American Political Science Review 86(1), 1992: 149-166.

Weaver, Mary Anne. "The Short, Violent Life of Abu Musab al-Zarqawi." The Atlantic, July/August 2006. Retrieved from (http://www.theatlantic.com/magazine/archive/2006/07/the-short-violent-life-of-abumusab-al-zarqawi/304983/).

Weber, Max. "Politics as a Vocation." In From Max Weber: Essays in Sociology, edited by Hans H. Gerth and C. Wright Mills, 77-128. New York: Oxford University Press, 1946.

Weber, Max. "The Three Types of Legitimate Rule.” Translated by Hans Gerth, Berkeley Publications in Society and Institutions 4(1), 1958: 1-11.

Weisman, Steven R. "The Struggle for Iraq: Diplomacy; Powell Gave Iraq 6 Months to Write New Constitution," New York Times, Sept. 26, 2003. Retrieved from (http://www.nytimes.com/2003/09/26/world/struggle-for-iraq-diplomacy-powell-givesiraq-6-months-write-new-constitution.html).

White, Jeffrey and Brooks Neuman. "The Sunnis, the Insurgents, and the Elections." The 
Washington Institute, December 20, 2005. Retrieved from

(http://www.washingtoninstitute.org/policy-analysis/view/the-sunnis-the-insurgents-andthe-elections).

Whitlock, Craig. “Al-Zarqawi’s Biography.” The Washington Post, June 8, 2006.

Retrieved from

(http://www.washingtonpost.com/wpdyn/content/article/2006/06/08/AR2006060800299. html?nav=rss world/africa).

Whitlock, Craig. "Zarqawi Building His Own Terror Network." The Washington Post, October 3, 2004. Retrieved from (http://old.post-gazette.com/pg/04277/388966.stm).

Wight, Martin. System of States. Edited by Hedley Bull. Leicester, 1977.

Wiktorowicz, Quintan, “Anatomy of the Salafi Movement", Studies in Conflict and Terrorism 29, 2006: 207-39.

Williams, Brian G. "Afghanistan After the Soviets: From Jihad to Tribalism," Small Wars \& Insurgencies 25(5-6), 2014: 924-956.

Williams, P. L. The al-Qaeda Connection: International Terrorism, Organized Crime, and the Coming Apocalypse. New York, NY: Prometheus Books, 2005.

Williams, Timothy and Duraid Adnan. "Sunnis in Iraq Allied with U.S. Rejoin Rebels." The New York Times, 16 October 2010. Retrieved from (http://www.nytimes.com/2010/10/17/world/middleeast/17awakening.html?pagewanted= all\& $\mathrm{r}=0)$.

Wimmer, Andreas. Nationalist Exclusion and Ethnic Conflict: Shadows of Modernity. Cambridge: Cambridge University Press, 2002.

Windrem, Robert. "Saudi Arabia's Ambitious al-Qaida Fighter.” NBC News, 11 July 2005. Retrieved from (http://www.nbcnews.com/id/8304825/ns/dateline nbc/t/saudi-arabiasambitious-al-qaida-fighter/\#.WG 4SvkrJnI).

Wohlfoth, William C. "The Stability of Unipolarity." International Security 24(1), summer 1999: 5-41.

Woodward, Bob. State of Denial: Bosh at War, Part III. New York: Simon \&Schuster, 2006.

Wright, L. The Looming Tower: Al-Qaeda and the Road to 9/11. (First Ed.), New York, NY: Vintage Books, 2006.

Wright, Robin. Sacred Rage: The Wrath of Militant Islam. New York: Touchstone, 2001.

Young, Crawford. The African Colonial State in Comparative Perspective. New Haven and London: Yale University Press, 1994.

Yurdusev, A. Nuri. “'Level of Analysis' and 'Unit of Analysis': a Case for Distinction.” Millennium: Journal of International Relations 22(1), 1993: 77-88.

Zartman, Ira William. Collapsed States: The Disintegration and Restoration of Legitimate Authority. Boulder: Lynne Rienner Publishers Inc. 1995.

Zekulin, Michael. 'Endgames: Improving Our Understanding of Homegrown Terrorism.' Studies in Conflict \& Terrorism, 39(1), 2016: pp. 46-66.

Zimmerman, Katherine. "The Al-Qaeda Network: A New Framework for Defining the Enemy." American Enterprise Institute, September 2013. Retrieved from (http://www.aei.org/wp-content/uploads/2013/09/-the-al-qaeda-network-a-newframework-for-defining-the-enemy 133443407958.pdf).

Zinn, Cherish M. "Consequences of Iraqi De-Baathification." Cornell International Affairs Review 11(2), 2016: 1-14.

Zirakzadeh, C. E. "From Revolutionary Dreams to Organizational Fragmentation: Disputes Over 
Violence Within ETA and Sendero Luminoso." Terrorism and Political Violence 14(4), 2002: 66-92.

Zucchino, David. "Why Iraqi Army Can’t Fight, Despite \$25 Billion in U.S. Aid, Training." Loss Angeles Times, November 3, 2014. Retrieved from (http://www.latimes.com/world/middleeast/la-fg-iraq-army-20141103-story.html).

Zunes, Stephen. "The United States: a hegemon challenged," in the International Relations of the Contemporary Middle East: Subordination and After, edited by Tareq Y. Ismael and Glenn E. Terry, 73-110. London and New York: Rutledge, 2014. 